PROTEST AND SOCIAL MOVEMENTS 
Breaking Down the State 


\section{Protest and Social Movements}

Recent years have seen an explosion of protest movements around the world, and academic theories are racing to catch up with them. This series aims to further our understanding of the origins, dealings, decisions, and outcomes of social movements by fostering dialogue among many traditions of thought, across European nations and across continents. All theoretical perspectives are welcome. Books in the series typically combine theory with empirical research, dealing with various types of mobilization, from neighborhood groups to revolutions. We especially welcome work that synthesizes or compares different approaches to social movements, such as cultural and structural traditions, micro- and macro-social, economic and ideal, or qualitative and quantitative. Books in the series will be published in English. One goal is to encourage nonnative speakers to introduce their work to Anglophone audiences. Another is to maximize accessibility: all books will be available in open access within a year after printed publication.

\section{Series editors}

Jan Willem Duyvendak is professor of Sociology at the University of Amsterdam. James M. Jasper teaches at the Graduate Center of the City University of New York. 


\title{
Breaking Down the State
}

\author{
Protestors Engaged
}

\author{
Edited by \\ Jan Willem Duyvendak and James M. Jasper
}

Amsterdam University Press 
Cover illustration: Parliament building in Ukraine with flag

Photo: ANP / AFP Photo / Genya Savilov

Cover design: Coördesign, Leiden

Typesetting: Crius Group, Hulshout

Amsterdam University Press English-language titles are distributed in the US and Canada by the University of Chicago Press.

ISBN $\quad 9789089647597$

e-ISBN $\quad 97890485^{2} 5386$ (pdf)

DOI $\quad 10.5117 / 9789089647597$

NUR $\quad 756$

(C) Jan Willem Duyvendak and James M. Jasper / Amsterdam University Press B.V., Amsterdam 2015

All rights reserved. Without limiting the rights under copyright reserved above, no part of this book may be reproduced, stored in or introduced into a retrieval system, or transmitted, in any form or by any means (electronic, mechanical, photocopying, recording or otherwise) without the written permission of both the copyright owner and the author of the book. 
For Edward Snowden,

and thousands more whistleblowers like him 
The State ... does not exist in the phenomenal world; it is a fiction of the philosophers. What does exist is an organization, i.e., a collection of individual human beings connected by a complex system of relations. Within that organization different individuals have different roles, and some are in possession of special power or authority, as chiefs or elders capable of giving commands which will be obeyed, as legislators or judges, and so on. There is no such thing as the power of the State; there are only, in reality, powers of individuals - kings, prime ministers, magistrates, policemen, party bosses, and voters.

- A.R. Radcliffe-Brown 


\section{Contents}

Introduction

Players and Arenas Formerly Known as the State

James M. Jasper

\section{Part 1 The Rules of Law}

1 The Courts

Criminal Trials as Strategic Arenas

Brian Doherty and Graeme Hayes

2 Political Parties and Legislators

A Latin American Perspective

Hélène Combes

3 Political Parties and Legislators

An American Perspective

Katherine Krimmel

4 Contentious Governance

Local Governmental Players as Social Movement Actors

Imrat Verhoeven and Christian Bröer

\section{Part 2 The Forces of Order}

5 The Police

Donatella della Porta and Kıvanç Atak

6 The Military

The Mutual Determination of Strategy in Ireland, 1912-1921

Ian Roxborough

7 Infiltrators

David Cunningham and Roberto Soto-Carrión 
8 Liberal Violence

Strategies of Repression in Transitional Regimes

Vince Boudreau

\section{Part 3 International Arenas}

9 The United Nations

Gay versus Anti-Gay Players in Transnational Contention

Clifford Bob

Conclusion

225

Simplicity vs. Complexity in the Analysis of Social Movements Jack A. Goldstone

Contributors

Index

\section{List of Figures and Tables}

Figure 3.1 Percentage of Bills Introduced in the US House Reported from Committee and Passed

Figure C1 Tilly's Polity Model, Static Version

Figure C2 A More Complex View of Fields of Action for Social Movements

Table 2.1 The Non-Partisan Engagements of National, Regional, and Local Leaders of the PRD between 1968 and 1997

Table 2.2 Arenas and the Resource Transfers of Multi-Positioned Players

Table 5.1 Styles of Policing, or "Interaction"

Table 5.2 Protest Policing Strategies

Table 8.1 Domination vs. Contestation 


\title{
Introduction
}

\author{
Players and Arenas Formerly Known as the State
}

James M.Jasper

Those who study protest and social movements recently emerged from a period of paradigm wars (Goodwin and Jasper, 2004). Structuralists began to incorporate culture and to develop more dynamic models (McAdam et al., 2001; Tilly, 2008). Culturalists began to add emotions to the frames, identities, and narratives that were their major tools (Gould, 2009). Both historical (Marxist and Tourainian) theories and rational-choice theories faded from the landscapes in both the United States and Europe (Accornero and Fillieule, 2015). This should open the way to theoretical synthesis, but instead there has been more of a retreat from theory altogether (Rucht, 2015).

Yet from the rubble a new synthesis has recently begun to emerge. It is more micro than macro, but more cultural than the traditional micro approaches of rational-choice and game theories (Jasper, 2010; 2012a). Its focus is on strategic interactions, in which players emerge and engage one another in structured arenas. Although it revives elements of the Chicago School of Robert Park and Erving Goffman, the new paradigm - if we can apply such a grand label to a collection of middle-range theories - is not directly related to any of the grand paradigms of the past (Cefaï, 2006). It can incorporate emotions, leaders, and creativity - concepts neglected in many older theories - without abandoning structures, culture, and other traditional concepts. It also acknowledges the decisions at the heart of rational-choice theory and the expectations from game theory.

Breaking Down the State aims to elaborate on this strategic perspective, also developed in the companion book Players and Arenas. That volume examined other major players: internal factions, foundations, corporations, professions, unions, intellectuals, scientists, the media, religious groups, and bystanders. This book looks at official state arenas plus the United Nations. Both volumes are concerned with the interactions between protestors and these other prominent players. Here are some components of this strategic interactionist view, developed more thoroughly in the introduction to Players and Arenas (also Jasper, 2004; 2006).

- Models should include both simple players (individuals) and compound players (teams). 
- Individuals can influence events and understandings both as direct decision makers and as symbols representing groups and moral positions.

- Every player (even simple players) can also be viewed as an arena in which decisions are made.

- Players grapple with a number of strategic goals, trade-offs, dilemmas, and choices.

- Players are audiences for each other's actions, and so must be treated through an interpretive, cultural lens, including acknowledgement of their emotions.

- Players deploy three basic means: they try to persuade others, to coerce them physically, or to pay them to do what they want; they also occupy positions in arenas that allow them to do these three things.

- Boundaries of both players and arenas are porous, to varying degrees; players especially are constantly shifting and re-forming.

- Arenas are governed by a range of formal and informal rules, even though the rules are forever being broken, bent, ignored, and reinterpreted.

- Players often shift arenas in the search for new advantages.

- What appears as "contingency" in more structural models can often be explained in strategic models through patterns of choices and interactions.

Among other things, the new strategic view both builds on and challenges one of the mainstays of structural theory: for several decades, the study of social movements centered on the relationship between movements and the state. In this view "the state" is both opponent and judge for protestors, who are generally demanding admission to the polity - many scholars have even defined social movements as efforts by the oppressed to become full citizens (McAdam, 1982: 25). During the same long period, in political sociology and political science, many burning questions about the state revolved around its relationship to Society: How autonomous is the state from society? Is there a ruling class? What are the social origins of state officials? In some cases, the same scholars, such as Charles Tilly or Theda Skocpol, studied both states and their challengers. For a long time, the States-and-Movements paradigm generated exciting research on politics.

Recently the pendulum has begun to swing to questioning whether "movements" and "states" are not a bit of a fiction, implying a unity for each that does not really exist. What exactly are social movements? A kind of public opinion in favor of change? Networks of individuals and organizations? A collective identity? A series of public events and statements? What 
are a movement's boundaries? Does the movement include an individual who shows up for one demonstration?

Similarly, what is the state? What are its boundaries with the rest of society? With the rest of the world? How much unity do we see in the decisions made by its various agencies, officials, and politicians? How often do legislators and the police, for instance, pursue the same goals? What happens when they do not? Or when the army clashes with the president? Does it make sense analytically (as opposed to rhetorically) to even speak of the state, or a social movement, as an agent doing something?

We try in this volume to deploy more persuasive images of both movements and states by breaking the latter down into the parts that really matter, where decisions are made, policies implemented, data gathered, and more. What is a state? For one thing, it is a web of sub-players (bureaus, legislatures, executives, police forces, and so on) tied together by a set of rules (laws, norms, and traditions) that purport to govern their relationships but do so very incompletely. Each sub-player of the state brings a variety of capabilities to its strategic engagements, which include many informal interactions as well as the formal ones covered by laws. Even the laws are regularly reinterpreted or changed as a result of strategic campaigns by interested players. Because strategic action is only partly covered by formal rules, the boundaries of state agents are porous, with a range of other players included in some ways at some times, excluded at others. In almost no cases does "the state" act as a unified player.

This does not mean that state players do not get anything done; they do an immense amount. Taxes are collected, wars launched, borders patrolled, corporations are enabled and constrained, the rights of minorities are protected or violated, protestors are beaten or tolerated, and thousands of other actions take place every day. But "the state" does not do these things; sub-units of it do. Tax agencies collect taxes, municipal police departments control protests. These sub-players usually patrol their own arenas. Much government action occurs precisely when one part of the state achieves relative autonomy from other parts that might interfere with it, or when it manages to cooperate with other state sub-players, a coordination that can never be assumed in advance. (Arenas contain as much cooperation as conflict.) Typically, for instance, agencies try to insulate themselves from legislative interference. We can usefully envision the state as a "complex amalgamation of agencies, charged with distinct functions, having domains that are frequently overlapping, and often compelled to compete for resources" (Chibber, 2002: 957).

But this view, while recognizing the state's complexity, still assumes too sharp a distinction between what is inside and outside the state. States 
include arenas in which a variety of players participate: courts, elections, administrative hearings, and more. Units of the state participate in other arenas, too, such as markets, the media, and public opinion. One part of the state can be an arena in which another segment of the state is a player; sub-players often lobby each other, as chapter 4 shows. In what Javier Auyero (2007: 20) calls "the grey zone," individuals can be both state or party officials and be protestors trying to pressure the state.

Whether we view a segment of the state as a player or as an arena sometimes depends on our analytic interests: all players are also at the same time arenas in which decisions are made. But some players are arenas in another sense: their role is to produce arenas for other players. Courts are especially clear cases. As an initial approximation, if a group of people share goals, coordinate their action, and have some collective identity, they are a player. If they organize a place where interactions occur, with some rules and some outcome at stake, they are an arena. It is apparent how many groupings can be both player and arena at the same time.

With social movements, too, we see a range of players whose interaction makes up what is commonly called a movement. There are formal organizations, with resources and internal rules, often governed by laws. There are informal groups with few formal rules and varying amounts of informal tradition. There are networks of individuals and organizations. There are campaigns which bring together formal and informal (and shifting) alliances of these various players. Within these compound players there are, of course, individuals, many of whom have the clout to strike out on their own from time to time. We see this most clearly, perhaps, with celebrities, who bring attention to their favorite causes but also sometimes remake those causes according to their own tastes. (A case of the powerful allies dilemma: we want allies who are strong because they can help us, but their very strength allows them to bend us to their purposes instead of helping us attain our own goals [Jasper, 2004: 8].)

All players, especially those as sprawling as states and movements, can be broken down into sub-players, who engage one another for influence over decisions. A sub-player can in turn be broken down further, and so on. Ultimately, we get to the level of individuals, whose role has never been well explained in political sociology. We need to follow John Ikenberry's suggestion (1988: 46) that "we pay attention to the activity of executive officials as they are influenced and constrained by larger international and domestic structures." A proper strategic approach shifts back and forth between these perspectives, of players and of arenas, combining and disaggregating players to follow decisions and actions. Analysts sometimes 
describe these layers as multi-level games, although the analogy relies on an unsustainable differentiation between distinct games (della Porta and Kriesi, 1999). The same conflict can spill across different arenas.

Even if they are not unified players, "states" and "movements" matter as rhetorical references. Appeals to the nation as under threat still encourage young women and men to enlist in the military forces (note the plural: the forces often compete with each other for prestige and resources). A nation's flag, symbol of its unity, still inspires positive feelings in many. It is easy to castigate our nation's "enemies" in simplistic terms, speaking of "the Soviets" or "Iran" as though they were all of one mind, a united (and hence more dangerous) foe. Similarly, belonging to a "social movement" is inspiring, as it suggests a national or international effort of people like oneself, all aiming at the same goal through compatible means. The image of such an entity, powerful and eventually triumphant, is a rhetorical accomplishment. Heroes and villains are alive and well in political propaganda, even though they have disappeared from sophisticated fiction (Jasper et al., forthcoming).

The collective identities so important to social movements have been recognized as necessary fictions: necessary for sustaining collective action, but in the end fictional in the sense that they paper over considerable heterogeneity in the groups they are meant to represent (McGarry and Jasper, 2015). States and movements are necessary fictions in much the same way. They pretend to have more unity than they do, and they claim to speak and act as representatives of a united territory or people. Both movements and states help bring themselves into being through the performances of their own claims and actions.

Philip Abrams (1988) made a similar point years ago: "the state" is a claim that is intended to legitimate all sorts of activity that occur in a complicated "state system" (Miliband, 1969). The term attributes democratic will and intention to activities that are in fact meant to benefit ruling elites. (Of course, in the hands of Marxist rhetoricians like Abrams, the term the state is meant to do just the opposite, attribute unity and intentionality to those elites who control it.) So even Abrams thought there was a unified state system beneath the performative mask of the reified state.

The reification of a unified state reaches its apogee in Weberian traditions, which emphasize the capacities of states - both military and financial - and their autonomy from the rest of society. Theda Skocpol, for instance, in her introduction to the 1985 volume Bringing the State Back In, explicitly criticizes pluralist and structural-functional theories for seeing the state 
purely as an arena in which societal interests battle it out, but also Marxist theories for viewing it as a mere instrument of the ruling class. Her focus on the coercive power of the state inevitably exaggerates its unity, even when, as in the 1980 , the state's fiscal capacities are also acknowledged (these are often seen to depend ultimately on a state's coercive power [Tilly, 1985]). State officials also persuade, but they do many, many additional things that often conflict with each other: they employ the unemployed, they create scientific knowledge, they restrict the heights of buildings, they protect the rich, they clean the air and water, they promote the health and safety of workers, they guarantee home loans and bank accounts.

Theorists of revolution, who necessarily focus on the interactions between challengers and the state, began to see this entity less as a monolithic structure than as a set of strategic players who interact with challengers. Although he does not quite put it in strategic terms, Jeff Goodwin (2001) shows that revolutions unfold according to an interactive logic: revolutionary movements emerge in response to actions by the main components of the state (dictators, police, armies, party officials), whose further actions determine whether revolutions succeed or fail. Above all, both revolutionaries and states react nastily when the other side threatens their own existence. The salient state player in revolutions is the army, and Goodwin (2001: 248) highlights the cultural beliefs and practices of officers, their economic incentives and corruption, and their interactions (and privileges) with other state players (also Stepan, 1988). Like the study of protest, the study of revolutions could benefit from an explicit attention to strategic interactions and dilemmas (see chapter 8 below and Boudreau, 2004).

Except for the realist tradition in international relations, political scientists have generally had a more nuanced vision of states than sociologists of protest have. Even in international relations, James Rosenau (1990: 117) criticized the idea of the state "as an actor whose nature, motives, and conduct are so self-evident as to obviate any need for precise conceptualizing," while Anne-Marie Slaughter (2004: 12) calls for "disaggregating" the state to get beneath "the fiction of a unitary will and capacity for action." Yale Ferguson and Richard Mansbach (2004: 15) have further broken down the state, arriving at a strategic perspective in which politics "is a seamless web extending from individuals in families and other communities all the way to global structures, and what has been called 'international relations' is neither a distinctive field nor discipline."

This new emphasis on the micro-interactions of politics is compatible with, and much influenced by, Michel Foucault's famous capillary vision 
of power, as something that is not imposed by a central state but generated throughout society's institutions during recurring interactions. He aimed to "decapitate" the sovereign in theories of the state. The disciplinary practices that he described, carried out by experts and supported by discourses of knowledge, cut across traditional boundaries of what is inside and what is outside the state, dividing up the world in a different way. Yet even in the Foucauldian tradition, power is sometimes reified as though it were a thing that structures interactions but is also created by them. I prefer to see people as having various resources, organizational positions, and degrees of authority (possibly based on expert knowledge and credentials), and then making strategic choices to set all these in motion. The actions and outcomes are shaped by these unequal advantages, but not pre-determined by them.

Scholars of protest have occasionally called for more attention to the "internal workings of government" (Zald, 1992: 339) to overcome the field's "movement-centered" bias (McAdam et al., 2001; McAdam and Boudet, 2012), but few researchers have heeded the call. China specialists Kevin O'Brien and Lianjiang Li (2006: 1) are exceptions, complaining that, "Thinking in terms of two parties can be especially misleading in those cases when aggrieved persons employ government commitments and established values to persuade concerned elites to support their claims." They focus on horizontal divisions of the state, following "rightful" resisters as they jump to higher levels to pursue their grievances, often expressing faith that the true intentions of the central government are being corrupted by local officials. This "principal-agent" challenge may be especially severe in a nation as large as China, but all states face some version of it in the implementation of official decisions. ${ }^{1}$ What is more, states are also divided into vertical segments, as industry ministries, for instance, battle finance ministries or elected officials (Jasper, 1990). "Political opportunities" are

1 To quote O'Brien and $\operatorname{Li}(2006: 51)$ further, "It is important to think about 'them' more systematically by disaggregating the state. This prescription, uncontroversial though it sounds, goes well beyond the familiar injunction to avoid reifying state power. It involves recognizing that every regime has its own institutional structure and that agents of a government are not always principled agents. Particularly in far-flung, many-layered bureaucracies, officials at different places in the hierarchy often have diverging interests and are subject to different constraints and incentives. From the vantage point of people contemplating collective action, this means that states often present attractive, multidimensional targets... And these openings appear not only because there are regime defectors, minority elites, or elites out of power who seize the role of tribune of the people." As we break down the state analytically, we can see that there are always "political opportunities" due to the interactions among the various players who comprise the state. 
always there, in some form, rather than being special results of infrequent crises (Jasper, 2012b).

More often, the reigning structural approach to states and movements proceeds by reducing the state to a simple typology of regimes based on a couple of variables. Thus it would seem, according to the Charles Tilly of Regimes and Repertoires (2006), that the state dimensions which matter to social movements are institutional capacity and a regime's level of democracy. To be fair, at other times Tilly (2005) suggested that such broad categories need to be broken down into causal mechanisms, which would be in line with our strategic approach, but here and in his other research the "regime environment" remained fairly structural and static. Yet the "environment" of a social movement consists of other players, so it seems more straightforward to examine engagements rather than environments, interactions rather than "relationships" (Jasper, 2012b). ${ }^{2}$

Even in sophisticated research, such as Tilly's, regimes are put in static boxes with little room for strategic choices. A patrimonial regime will act ... like a patrimonial regime. A capitalist state will protect capitalism. (I suspect that Tilly's typological approach owes a debt to Marxist theories of the state, which were concerned with identifying what was or was not an "essentially" capitalist state, versus others that might be revolutionary.) It sometimes seems, in these theories, as if the structures impose such severe constraints on players that they do not have decisions to make. Although we do not want to deny external constraints, a strategic perspective helps us observe maneuvers within them. These constraints are imposed by the actions and reactions of other players. ${ }^{3}$ We must picture politics as a long sequence of interactions among many players, including but not confined to protestors and state players (Rasler, 1996; Goldstone, 2004; Jasper, 2004).

Scholars of social movements no longer think of protestors as "challengers" or "outsiders" seeking entry to the polity, a view that was once at the heart of political-process theory thanks to Tilly's pathbreaking work on the nineteenth century and McAdam's (1982) on the US civil rights movement. Instead of some distinct line between insider and outsider, Goldstone (2003:9) offers "a continuum of alignment and influence, with some groups having very little access and influence through conventional politics, others

2 Citing how researchers have distorted Swedish social movements, Abby Peterson (2015) blames dichotomized variables for necessarily oversimplifying complex cases.

3 Edwin Amenta offers a more sophisticated "mediation model," suggesting that the success of different strategies also depends on whether elected official and state bureaucrats are sympathetic to the goals and interests of protestors: Amenta, Halfmann, and Young (1999), Amenta (2006). 
having somewhat more, and still others quite a lot; but groups may move up and down this continuum fairly quickly, depending on shifts in state and party alignments." This view has a healthy dynamism, although it may not go far enough toward breaking the state down into its component parts. It assumes that the main influence is through political parties, and it still seems to assume a relatively unified state.

In other work Goldstone (2004: 357) suggests replacing "political opportunity structures" with "relational fields," which would include other movements and countermovements, political and economic institutions, various levels of state authorities and political actors, assorted elites, diverse publics, symbolic and value orientations, and critical events. Here as elsewhere, the concept of fields lumps together players and arenas, along with actions and culture (see Jasper, 2015, for a comparison of fields with our players-and-arenas approach). But the point about many players, including multiple parts of the state, is well taken. Instead of a movement facing a state (Rucht, 2004: 197), we need to imagine a "large co-evolving context in which the characteristics and actions of any contender are facilitated and constrained by the characteristics and actions of all other actors in the environment" (Bosi, 2008: 244).

We can better see the interaction between arenas and players if we concentrate initially on players' actions. In strategic engagement there are three basic types: persuasion, coercion, and payment. These are the things that players do to get what they want (Jasper, 2006). Persuasion, in particular, operates across formal boundaries, although the contacts with various audiences are sometimes highly structured, as with access to the news media or standing in courts. Payments can either recognize the formal boundaries of organizations, flowing through proper channels, or ignore them, flowing instead (usually illegally) to individuals within the organizations. When we identify who actually does what, we can see how important sub-players are. Such actions "assemble" various individuals and physical resources, often in the name of a fictive compound player such as a state or social movement (Latour, 2005).

The language of players and arenas is meant to overcome longstanding debates about agency and structure in order to move toward a dynamic, strategic model. All social interactions contain both agency and structure, since these are primarily analytic interests. One solution has been to distinguish static periods from critical junctures when people's choices and actions matter more (Swidler, 1986; Katznelson, 2003; Capoccia and Keleman, 2007). The problem with contrasting stable and unstable periods is 
that it tends to place all the structure in one and all the agency in the other. For most authors, this is a structural solution, since it is the breakdown of institutions, from internal collapse or external shocks, that creates openness to change. A more agentic view suggests that players can sometimes create - rather than waiting for - critical junctures, which are acknowledged as critical only later (Goodwin, 2001; Kurzman, 1996).

Players develop expectations based on past interactions and reputations. They do not start each engagement from scratch. There is, in the ungainly term, "path dependency." A strategic approach helps us understand how players can be more or less constrained by past choices. It suggests that individuals, who are never fully socialized into their institutions, can bring new points of view to situations, including situations of apparent stalemate or equilibrium. In addition, strategic dilemmas often force players to innovate, as they recognize they are trapped in old ways of doing things.

If we pay closer attention to arenas, we may be better able to understand the kinds of constraints placed on players. A broad structural factor such as a "fiscal crisis of the state" enters arenas when one player cannot pay other players, or its component members, who react in turn. Or the perception of a fiscal crisis may lead other players to react, such as refusing to lend money to the Finance ministry, or to buy state-issued bonds. Structures matter when they prevent or allow players to do things: to pay, coerce, or persuade others. Most of the external constraints on one player come from the actions of other players; they do not come - at least not directly - from structures. (The metaphor of a structure, like a building channeling our movement through doors and hallways but preventing us from going through brick walls, is misleading.)

New arenas provide new opportunities for action. You can't bring a lawsuit in a nation without courts. Tilly (1997: 250), the great student of how arenas shape players, comments on the increasing centrality of Parliament in Great Britain in the early nineteenth century: "It weakened the autonomy and power of the crown and of great lords, reduced direct involvement of troops and other repressive forces in claims-making, and diminished the importance of local dignitaries both as objects of contention and as vehicles for the relaying of claims to higher authorities." The institutional changes did not entirely close off old arenas or entirely push action into new ones: they shifted the potential benefits and costs of various strategic programs. They promoted persuasion at the expense of payments and especially of coercion in domestic politics.

Players interacting in structured arenas: this sounds like game theory, which has done the most to develop this perspective in the social sciences. But 
game theory is barely a social science, as opposed to an applied branch of mathematics. Its inadequacies for our purposes include a focus on games that have clear endpoints, from which observers can work back to discover the best choices; a limited range of goals, which for humans are much more complicated than game theory can model (as opposed to evolutionary game models that can concentrate on number of offspring as the only important outcome); a fondness for mathematical precision over messy realism; an inability to adequately incorporate humans' interpretations of what they are doing; and an assumption that players can anticipate many moves ahead (whereas one or two is about it). Games end, politics does not. As Clifford Bob (2012: 6) puts it, "most 'outcomes' are at best respites in wars lasting decades. Win or lose, the combatants fight on. They adapt themselves to the changed conditions, even while undermining them. They assert their root visions in new guises or different arenas." After a policy decision, the battle often turns to implementation, where the losers can still block the decision, turning it into a "zombie policy."

We can see the strengths and weakness of game theory, to take just one example, in Karklins and Petersen's (1993) analysis of regime-protestor interactions in 1989 in Eastern Europe. They wisely break down "regime" and "masses" into their component parts, ultimately down to the individuals who must in the end make strategic calculations. They also recognize the complex perceptions that go into these choices (although, like most game theories, they do not have a sophisticated analysis of the cultural and emotional processes that shape these perceptions). And they focus on a series of decisions and actions, back and forth between state agencies and people in the street. By the time they have all these theoretical pieces of a strategic engagement in place, their final step labeling it a set of assurance games - adds little to our strategic model. The unique contribution of game theory is the least useful part of their sensible explanation.

Wins and losses may inspire or impose new strategies, especially shifts to different arenas. Losses, if they are not altogether devastating, can often be the rallying cry for further mobilization, as "the power of the negative" kicks in (Jasper, 1997: 362). There is even struggle over the definition of wins and losses. Describing an outcome as a win for your team gives your members confidence; a loss makes them either depressed (deflating action) or indignant (encouraging action). "After an institution's decision," Bob (2012:33) points out, "much of the conflict involves portraying the outcome as either a win or a loss - or sometimes both in different settings." Both sides in a controversy often claim victory in the same result. 
If we desire a strategic approach to players that highlights agency, we may wish to focus on the trade-offs these players face. When they recognize the trade-offs, they become dilemmas, with which players must grapple (Jasper, 2006). One of the most common is what I call Naughty or Nice, a choice between aggressive tactics of which most players, authorities, and the public disapprove versus tactics that are popular and nonthreatening. Naughty options heighten the risks: there is usually more to be gained from disruption, physical coercion, and aggression, but also more to be lost, in that disruptive players often arouse a sharp reaction from authorities. A strong backlash may even kill off the player. Both protestors and their opponents face the Naughty or Nice dilemma; in chapters 5,6 , and 8 we see both dictators and police in liberal democracies grappling with the amount of force to use against dissidents.

In this volume we try to develop a more strategic-interactive picture of politics, full of actions and reactions, expectations and calculations, and also emotions: reactions like anger, moods such as cynicism, and long-run patterns of love and hate. A strategic vision respects the rich complexity of the people we study instead of reducing them to stick figures. We owe them that. We also owe that to ourselves, because we end up with fuller, better explanations.

Brian Doherty and Graeme Hayes examine the interactions between protestors and the courts in chapter 1 with cases from Britain and France. For many protest movements, direct action is intended to open the new arena of a public trial. Not only the media, but juries and prosecutors become players here. Juries matter to protestors in Britain because they represent the moral view of their fellow citizens, in addition to rendering a verdict. They often acknowledge the justice of protestors' claims and their sense of urgency.

Chapters 2 and 3 examine legislators and political parties, one with an emphasis on the United States (by Katherine Krimmel) and the other on Mexico (by Hélène Combes). Movements often view laws as their ultimate aim, but pushing policies through complex decision-making bodies like legislatures can be very difficult, even for movements with powerful allies. Lawmakers' primary goals, the tools they typically employ, and the institutional rules and norms all facilitate and constrain the activities of protest movements.

Christian Bröer and Imrat Verhoeven examine governance networks in chapter 4, showing that government bureaucrats can act like social movements or encourage social movements. They use two Dutch cases to show how state players interact strategically with other state players, with bystanders, and with the publics they seek to mobilize. 
In chapter 5 Donatella della Porta and Kıvanç Atak analyze the police as one of the state's key players on the front lines engaged with social movements. Protest policing is an arena where interactions can be conflictual or cooperative in nature, conditioned by the political functions served by the police, the means and strategies of policing, police cognitive schemes, and the involvement of external players in policing.

Drawing on the case of the Irish struggle for independence (1912-1923), Ian Roxborough examines the strategies and cognitive frames of the Irish republicans and the British state in chapter 6, concentrating on the army as a sub-player. The collapse of British rule in Ireland was partly due to overcommitment elsewhere, but also to internal divisions within the British state between hardliners and moderates. All players adjusted their tactics to those employed by other players, including those on their own side, and the introduction of paramilitary police forces (the "Black and Tans") by the British state set in motion an escalating spiral that proved impossible to control.

David Cunningham and Roberto Soto-Carrión, in chapter 7, show how infiltrators exemplify the complexities associated with players who navigate - often simultaneously - multiple arenas of contentious political struggles. By conceptualizing the infiltrator role as emerging within diverse arenas, they replace easy assumptions about infiltrators as straightforward representatives of their employing agency, uniformly undermining the efforts of the groups that they penetrate, with more fluid conceptions of active and passive participation, and authentic versus deceptive behavior.

In echoes of chapters 5 and 6, Vince Boudreau shows in chapter 8 the strategic dance between dictators and demonstrators. Authoritarian regimes, like the police, face the Naughty or Nice dilemma, negotiating just how far they can repress or make concessions without alienating bystanders entirely on the one hand or showing fatal weakness on the other.

In chapter 9 Clifford Bob analyzes conflict at the United Nations between two compound players, a transnational activist network promoting gay rights and another opposing them. Documenting how the two players formed and acted in response to one another and to the specific characteristics of the UN arena, the chapter highlights both affirmative strategies by which they promoted their contrary goals and negative ones through which they sought to demobilize and destroy their rivals. Many players attempt similar character work on their opponents as well as shaping their own collective identities.

In the conclusion Jack Goldstone, whose work has done so much to promote a strategic-interactive vision, comments on the other chapters and suggests future directions for research and theory. 
These diverse cases all reveal how sub-players of the state pursue their own goals, instead of or at the same time as they pursue the official goals of the broader "state," but also how goals emerge from strategic interaction itself. Just as social movements turn out to be complex entities with many players, so do the states they interact with.

Jan Willem Duyvendak and I would like to thank the Eastern Sociological Society and especially its 2012 president Robert Zussman, for sponsoring the mini-conference upon which this volume is based, Marisa Tramontano and Gabriele Cappelletti for their work in preparing the manuscript for publication, two anonymous reviewers for their helpful comments, and the excellent staff at the Amsterdam University Press.

I thank Nitsan Chorev and Susan Woodward for their exceptional comments on an early draft of this introduction.

We thank Ed Hatton for copy editing.

\section{References}

Abrams, Philip. 1988. "Notes on the Difficulty of Studying the State." Journal of Historical Sociology 1: 58-89.

Accornero, Guya, and Olivier Fillieule, eds. 2015. Social Movement Studies in Europe: The State of the Art. New York: Berghahn Books.

Amenta, Edwin. 2006. When Movements Matter. Princeton: Princeton University Press.

Amenta, Edwin, Drew Halfmann, and Michael P. Young. 1999. "The Strategies and Contexts of Social Protest: Political Mediation and the Impact of the Townsend Movement in California." Mobilization 4: 1-23.

Auyero, Javier. 2007. Routine Politics and Violence in Argentina. Cambridge: Cambridge University Press.

Bob, Clifford. 2012. The Global Right Wing and the Clash of World Politics. Cambridge: Cambridge University Press.

Bosi, Lorenzo. 2008. "Explaining the Emergence Process of the Civil Rights Protest in Northern Ireland (1945-1968): Insights from a Relational Social Movement Approach.” Journal of Historical Sociology 21: 242-271.

Boudreau, Vince. 2004. Resisting Dictatorship. Cambridge: Cambridge University Press.

Capoccia, Giovanni, and R. Daniel Keleman. 2007. "The Study of Critical Junctures: Theory, Narrative, and Counterfactuals in Historical Institutionalism." World Politics 59: 341-369.

Cefaï, Daniel. 2006. Pourquoi Mobilise-t-on? Paris: Seuil.

Chernilo, Daniel. 2007. A Social Theory of the Nation-State. Routledge.

Chibber, Vivek. 2002. "Bureaucratic Rationality and the Developmental State." AmericanJournal of Sociology 107: 951-989.

della Porta, Donatella, and Hanspeter Kriesi. 1999. "Introduction." In della Porta, Kriesi, and Dieter Rucht, eds., Social Movements in a Globalizing World (London: Macmillan). 
Ferguson, Yale H., and Richard W. Mansbach. 2004. Remapping Global Politics. Cambridge: Cambridge University Press.

Goldstone, Jack. A., ed. 2003. States, Parties, and Social Movements. New York: Cambridge University Press.

—. 2004. "More Social Movements or Fewer: Beyond Political Opportunity Structures to Relational Fields." Theory and Society 33:333-365.

Goodwin, Jeff. 2001. No Other Way Out. Cambridge: Cambridge University Press.

Goodwin, Jeff, and James M. Jasper, eds. 2004. Rethinking Social Movements. Lanham: Rowman and Littlefield.

Gould, Deborah. 2009. Moving Politics. Chicago: University of Chicago Press.

Ikenberry, G. John. 1988. Reasons of State. Ithaca: Cornell University Press.

- 1990. Nuclear Politics. Princeton: Princeton University Press.

-. 1997. The Art of Moral Protest. Chicago: University of Chicago Press.

Jasper, James M. 2004. "A Strategic Approach to Collective Action: Looking for Agency in Social Movement Choices." Mobilization 9:1-16.

-. 2006. Getting Your Way. Chicago: University of Chicago Press.

- 2010. "Social Movement Theory Today: Toward a Theory of Action?" Sociology Compass 10: 965-976.

—. 2012a. “¿De la Estructura a la Acción? La Teoría de los Movimientos Socials después de los Grandes Paradigmas." Sociológica 27: 7-48.

—. 2012b. "Introduction." In Jeff Goodwin and James M. Jasper, eds., Contention in Context (Stanford: Stanford University Press).

—. 2015. "Introduction." In James M. Jasper and Jan Willem Duyvendak, eds., Players and Arenas (Amsterdam: Amsterdam University Press).

Jasper, James M., and Jan Willem Duyvendak, eds. 2015. Players and Arenas. Amsterdam: Amsterdam University Press.

Jasper, James M., Nicole Doerr, Michael Young, and Elke Zuern. Forthcoming. Moral Characters.

Karklins, Rasma, and Roger Petersen. 1993. "Decision Calculus of Protestors and Regimes: Eastern Europe 1989." The Journal of Politics 55: 588-614.

Katznelson, Ira. 2003. "Periodization and Preferences: Reflections on Purposive Action in Corporate Historical Social Science." In James Mahoney and Dietrich Rueschemeyer, eds., Comparative Historical Analysis in the Social Sciences (Cambridge: Cambridge University Press).

Kurzman, Charles. 1996. "Structural Opportunity and Perceived Opportunity in SocialMovement Theory: Evidence from the Iranian Revolution of 1979." American Sociological Review 61: 153-170.

Latour, Bruno. 2005. Reassembling the Social:An Introduction to Actor-Network Theory. Oxford: Oxford University Press.

Mansbach, Richard. 2004. Remapping Global Politics. Cambridge: Cambridge University Press.

McAdam, Doug, and Hilary Boudet. 2012. Putting Social Movements in their Place. Cambridge: Cambridge University Press.

McAdam, Doug, Sydney Tarrow, and Charles Tilly. 2001. Dynamics of Contention. Cambridge: Cambridge University Press.

McAdam, Doug. 1982. Political Process and the Development of Black Insurgency, 1930-1970. Chicago: University of Chicago Press.

McGarry, Aidan, and James M. Jasper, eds. 2015. The Identity Dilemma. Philadelphia: Temple University Press.

Miliband, Ralph. 1969. The State in Capitalist Society. London, Weidenfeld \& Nicolson. 
O'Brien, Kevin J., and Lianjiang Li. 20o6. Rightful Resistance in Rural China. Cambridge: Cambridge University Press.

Peterson, Abby. 2015. "Successful Social Movement Outcomes without Social Movements? The Case of Sweden." In Guya Accornero and Olivier Fillieule, eds., Social Movement Studies in Europe: The State of the Art. New York: Berghahn Books.

Rasler, Karen. 1996. “Concessions, Repression, and Political Protest in the Iranian Revolution." American Sociological Review 61: 132-152.

Rosenau, James N. 1990. Turbulence in World Politics. Princeton: Princeton University Press.

Rucht, Dieter. 2004. "Movement Allies, Adversaries, and Third Parties." In David Snow, Sarah Soule, and Hanspeter Kriesi, eds., Blackwell Companion to Social Movements. Oxford: Blackwell.

- 2015. "Conclusion." In Guya Accornero and Olivier Fillieule, eds. Social Movement Studies in Europe: The State of the Art. New York: Berghahn Books.

Skocpol, Theda. 1979. States and Social Revolutions. Cambridge: Cambridge University Press.

—. 1985. "Introduction." In Peter B. Evans, Dietrich Rueschemeyer, and Theda Skocpol, eds., Bringing the State Back In (Cambridge: Cambridge University Press).

Slaughter, Anne-Marie. 2004. A New World Order. Princeton: Princeton University Press. Stepan, Alfred. 1988. Rethinking Military Politics. Princeton: Princeton University Press. Swidler, Ann. 1986. "Culture in Action." American Sociological Review 51: 273-286.

Tilly, Charles. 1985. "War Making and State Making as Organized Crime." In Peter B. Evans, Dietrich Rueschemeyer, and Theda Skocpol, eds., Bringing the State Back In (Cambridge: Cambridge University Press).

—. 1997. "Parliamentarization of Popular Contention in Great Britain, 1758-1834." Theory and Society 26 : $245^{-273}$.

-.2005. Identities, Boundaries, and Social Ties. Boulder: Paradigm.

-. 2006. Regimes and Repertoires. Chicago: University of Chicago Press.

- 2008. Contentious Performances. Cambridge: Cambridge University Press.

Zald, Mayer N. 1992. "Looking Backward to Look Forward." In Aldon Morris and Carol McClurg Mueller, eds., Frontiers in Social Movement Theory. New Haven: Yale University Press. 
Part 1

The Rules of Law 



\title{
1 The Courts
}

\author{
Criminal Trials as Strategic Arenas
}

\author{
Brian Doherty and Graeme Hayes
}

In this chapter we analyze cases where social movement activists are prosecuted in the courts for protest actions. The courthouse is a significant arena for social movement strategy, a symbolic site for the arbitration of collective disputes, the legitimization of political action, and the production of social meaning; the court is "one of society's most sacred institutions since its role in defining, interpreting and enforcing the law puts it in close proximity to the moral basis of society" (Antonio, 1972: 291-292). The outcomes of trials depend on the organization of the criminal justice system but also the responses and strategies of multiple other players, inside and outside the court, including social movement activists, allies and supporters.

In common with the other chapters in this volume, our argument here is about "breaking down the state," about thinking through the relationships of power and agency that define the interactions between state and nonstate players. We seek to go beyond conceptualizations of state-movement relationships which might cast criminal trials merely as "state repression," setting out the architecture of the court as an arena for political interaction and tactical choice, identifying the players who act within it, and arguing that more attention be given to the courts in analyses of protest action.

\section{Social Movements and the Law}

It is perhaps surprising therefore that the study of social movements has so far afforded relatively little place to analyzing and understanding the role, forms and outcomes of criminal prosecutions in the trajectories of movements and the fates of the individual activists that constitute them. The criminal law - "arguably the most direct expression of the relationship between a State and its citizens" (Law Commission for England and Wales, 1989) - fulfills a role of symbolic social regulation; it defines, delineates, and enforces the codes which demarcate the sphere of legitimate social and political action, enabling the identification and repression of what is considered deviant, illegitimate behavior. Yet it is precisely on this line of demarcation that social movements operate, because they represent 
constituencies whose choices and identities are repressed by the law, or they organize challenges to the dominant arrangement of the social, political, cultural and economic order, or they engage in political actions which deliberately disrupt legitimated modes of interest representation. Indeed, as Dinos and Gibelin point out in their discussions of factory occupations in France in 1936, "all the achievements of the working class have involved methods operating either at the margin of the law, or in clear opposition to it" (1986: 130).

More generally, the relationship between social movements and the law is fundamental because the law is not just a system of social regulation and resource distribution but the site of production of systems of meaning. Courts are thus physical arenas in which defendants (one set of players) are ascribed symbolic roles: guilty or innocent, convicted or acquitted or discharged or, in some criminal justice systems, not proven; and, where guilt is demonstrated, they are arenas in which consequent tariffs are applied, reflecting the circumstances and gravity of the proscribed act. But courts are arenas for the production of meaning in other senses, including the construction of political and symbolic challenge, and the interplay of formal, rational-legal justice with other, "natural," extra-legal, forms of justice. In this sense, the goal of social actors, when they are challengers within the legal system, is to reveal the claims of the law to neutrality and universality as particular and partial relations of power. If, as Melucci says, the function of players in social conflicts is "to reveal the stakes, to announce to society that a fundamental problem exists in a given area" (1985: 797), then criminal trials offer a regulated space of engagement for the construction and revelation of these stakes through the interplays of persuasion and coercion.

The extensive literature on "legal mobilization" - broadly, "the idea that the law has the potential to be an effective instrument for political or social change" (Vanhala, 2011:6) - has developed a wide understanding of the roles, motivations, and effects on social movement campaigns of one set of the many players in the courts - in particular, legal professionals. The emphasis is foremost on cause lawyers, those who "commit themselves and their legal skills to furthering a vision of the good society" (Sarat and Scheingold, 1998: 3) and so help movements "define the realm of the possible" (Sarat and Scheingold, 2005:10), on collective litigation strategies articulated explicitly around rights claims making (Scheingold, 2010; McCann, 1994; Epp, 1998) and, on "legal opportunity," where the emergence, progress and outcomes of litigation are influenced, if not determined, by the conditions of access to the court arena (the attribution of "standing"), the availability of potential 
issue frames ("legal stock"), and the extent of judicial receptivity (Hilson, 2002; Andersen, 2005; De Fazio, 2012).

Here, we seek to broaden the analysis of social movements and the law. In the following sections of this chapter we therefore examine the strategies typically pursued by social movement players facing prosecution. Our principal focus is on groups involved in campaigns of deliberate lawbreaking in Western democracies, such as environmentalists, anti-advertising campaigners, and campaigners against nuclear weapons or militarism more generally. Following this, and as a necessary consequence, we examine how the formal rules of the judicial arena shape the choices available to various players, and how the players adapt tactically to the properties of the arena. We base our case mainly on evidence from civil (France and Belgium) and common law jurisdictions (England and Wales, and the United States), drawing out differences between the roles of judges, juries, prosecutors, and lawyers in each type of system, which then affect the form of the court as arena. Our data are drawn from observation of trials, trial reports, interviews with activists, and the alternative and mainstream media. We start by discussing the broad types of crime most relevant for social movement players.

\section{Social Crime}

In the late 196os and 1970s, influential Marxist historians in Britain began to discuss the development of the legal code in early modern England, and especially the extraordinary extension in the eighteenth century of capital criminal offences in what was widely known as the "Bloody Code." In their work (Hobsbawm, 1969; Hay et al., 2011; Thompson, 1975), they discussed and developed the notion of "social crime," where "the perpetrators operated within a broad local custom or customary consensus of right," and "often had the support or silent acquiescence of significant parts of the community" (Linebaugh, 2011: xlviii). The category of social crime revealed an embryonic working-class resistance to the development of the modern capitalist state based on individual property rights, opposing "customary forms of compensation" - poaching, smuggling, wrecking, the breaking of enclosures, and so on - to a criminal code that served the ruling class, "constantly recreating the structure of authority which arose from property and in turn protect[ing] its interests" (Hay et al., 2011: 25). In a 1979 essay, Rule refined social crime into two categories: "survival crimes," activities integral to "getting or supplementing a living," which were not held to be crimes by those committing them and were considered legitimate 
by popular opinion; and "protest crimes," such as pulling down fences, rick-burning, cattle-maiming and machine-breaking. In contrast, these were "not in themselves regarded as legitimate actions in all circumstances and by whomsoever committed" (Rule, 1997: 161, 156).

Defined in this way, "social" crime is closely connected with its particular historical context. The concept remains relevant, however, for understanding the choices and actions of players engaged in collective political challenges to prevalent social norms. Indeed, re-categorizing social crime as "direct action" and "civic" crime can enable us to better understand the kind of actions for which contemporary social movement players find themselves prosecuted in the courts. Here, "direct action" crime refers to action which is understood as unlawful even if politically legitimate by those undertaking it. It is deliberately undertaken as such in order to advance a collective cause. Our second category is "civic crime." Like Rule's "survival" crime, civic crime is not perceived or undertaken as deliberately unlawful, but is based in the customary praxis of a community or group which has been criminalized by power-holders, though it does not necessarily refer to actions integral to material survival. Contemporary examples of such praxis include struggles over civic rights and freedoms, and involve the criminalization of private behaviors as well as of public manifestations of collective identity in defense of a social, sexual or ethnic minority constituency. Those prosecuted for civic crime are not necessarily activists themselves, but their trials may become the focus for social movement campaigns. Examples might include the prosecution of homosexuality, of women for illegal abortions, or of women whose religious dress codes have been prohibited in public spaces.

Our focus in this chapter is on the first of our categories of social crime, direct action crime. We replace Rule's broader category of protest crime with this specific term in order to reflect the changes in the relationship between protest and citizenship that have taken place in the states forming our study since the eighteenth century. In this we follow Tilly's discussion of the transformation of protest in France and Britain between the mideighteenth and nineteenth centuries, from reactive to proactive claims by movements and from bifurcated to autonomous action repertoires (Tilly, $1978 ; 1995)$. This transformation resulted in the legalization of some forms of protest, and is reflected in the specificity of illegal forms of direct action in which discursive struggles for legitimacy are central, much as they were for Rule's "protest crime" in the eighteenth century.

Protesters prosecuted for "direct action crime" in our chosen states typically (1) stress their non-violence, (2) defend their actions in courts as those of responsible citizens, acting on the basis of collective moral principles, and 
(3) seek to persuade the magistrates and jury as fellow citizens that their actions were justified. Direct action crime thus includes civil disobedience but is not reducible to it. The latter is normatively considered to entail an acceptance of the right of the state to arrest and punish its adherents (Rawls, 1991; Bedau, 1991); but for some movements, illegal action is justified irrespective of whether the state decides to prosecute. A second difference from civil disobedience is that direct action crime is not necessarily intended as an appeal to the political authorities to place an issue on the political agenda or to "correct" oversights of the democratic system. Rather, direct action which causes material damage is often defended as politically legitimate in itself, whether carried out covertly or publicly. Furthermore, whereas for liberal political theory, once formal democratic rights have been achieved, social crime (both direct action and civic variants) is at best a theoretical paradox and at worst an oxymoron, for players engaged in contentious politics it captures the way that strategies for social and political change often involve illegal, challenging action and thereby establishes the political and normative, as opposed to the natural, character of law. In this sense, therefore, social crime is social movement politics by other means, and it is consistent with the argument that protest is likely to increase rather than decline in established democracies (Goldstone, 2004).

The idea of "social crime" has been the subject of much critical discussion, particularly over its unstable boundaries (see Lea, 2002: 37-39). We find the concept useful nevertheless because it highlights that the "anti-social" nature of criminal activity is not a pre-determined given. Rather, the social nature of crime depends upon its discursive production by movement players, as they seek to frame their (illegal) action such that its objectives are acknowledged to be not "individualistic, selfish, or cruel" (Linebaugh, 2011: xlviii). The definition of crime as social is thus one of the fundamental stakes of the trial process. The concept of social crime is useful, therefore, because it draws our attention to tactics and to interaction around the law; it enables us to cast our eyes toward the ways in which social movements seek to establish authority and legitimacy when their actions are criminalized.

\section{Trials, Players, and Arenas}

The significance of criminal prosecutions and trials therefore lies in the fact that they are regular, routine, "normal" activities for many social movements (Barkan, 2006: 183), undertaken in highly codified public settings, structured around the justification and opposition of ideas and actions, produced 
by the dynamic interaction of players whose roles are clearly defined, and which potentially carry far-reaching consequences. We may surmise that the transformative potential of criminal trials lies in a combination of their dramatic and didactic functions; for Falk, "the very limitations of time and space afforded by the courtroom promote a social concentration that enhances the narrative and legitimation potential of the proceedings" (2008:12). Above all, trials are a strategic arena for movement players. One experienced Belgian anti-militarist activist expressed it this way:

Law and the judicial system is part of the political battlefield. I am personally interested in how movements can act in this battlefield, keep their space for action open and disarm legal repression by turning it into something useful for their campaigns. Such strategizing means on the one hand looking at how legal systems frame the possibility to get rights and which space they leave for political action. This is both a question of finding legal arguments to base your cause on and coping with the framing of the debate through the legal procedure.

On the other hand trials take place in a political context. Of course legal repression is a mean to keep movements silent. For social movements strategizing implies looking at the possibilities to avoid prosecution, to turn trials into campaigning tools and how to be able to continue campaigning under repression. Court decisions and the decision to prosecute are heavily influenced by how society reacts. Coping with trials is not only a question of legal strategy, but also a question of media, mobilizing allies for public support and how to strengthen activists to drop their fear. ${ }^{1}$

In the courthouse, trials therefore present a series of tactical dilemmas for movement actors, with tactical considerations dependent upon strategic definitions of successful outcomes (the relationship between ideology and objectives) and the likelihood of their attainability (the interplay between players, resources, culture, and systems). Tactical decision making can therefore be expected to vary as a function of both the specific properties of the trial arena and the strategies deployed by opposing players, such as prosecutors and, occasionally, countermovements. In common law systems especially, the presence of a third set of players, jurors, can also be expected to affect the strategic calculus of players on both sides. The 
specific composition of trial arenas can therefore be a crucial factor in the structure of interaction.

In criminal trials in both civil and common law traditions, juries and magistrates broadly fulfill the same functions. Where they sit, it is the role of juries to decide on matters of fact, on the basis of the evidence and guidance in law presented to them; it is the role of magistrates to decide on matters of law, on the basis of analogy between the facts and the rules. In both civil and common law systems, where trials are heard without juries - in other words, by bench - magistrates combine the functions of ruling in fact and law; and in both systems, the vast majority of criminal cases are heard in this way.

These broad similarities of function mask significant cultural and operational differences between legal systems, however. In the Anglo-American tradition, juries are fundamental to the construction of the fairness of the criminal justice system. Juries are seen as representatives of the community and repositories of natural justice, capable of counterbalancing excessive state power; the defense in United States $v$. Berrigan, representing the Catonsville Nine (a group of anti-war activists who were put on trial in October 1968 for pouring napalm over and setting fire to draft board records in Catonsville, Maryland), said this to the jury: "[W]e are speaking to the community, and we are hoping to reach you, a microcosm, a small segment, 12 people, four alternates, who are the community sitting in judgment" (Kunstler, 1969: 72).

The jury remains a powerful symbol of citizen participation in the law - a symbolic power which may persist even where the jury's sociological composition is structured against the defendant. ${ }^{2}$ Tocqueville, indeed, recognizes that the jury is both a judicial and a political institution, placing fundamental social choices directly in the hands of the people, ${ }^{3}$ as important as universal suffrage to the exercise of popular sovereignty (1961: 405). In both England and the United States, the right to trial by jury is enshrined in the founding charters of the state (Magna Carta, the Declaration of Independence, the Constitution of the United States). As Pole points out, the jury's importance lies not simply in its socially representative nature, but in its capacity for moral agency: in early modern England, for example,

2 To be sure, the nature of the community represented in the jury is dependent upon the long-run rules of access which determine its racial, gender, and class composition, as well as short-term considerations for specific cases, and upon the practices of jury packing or jury strengthening (on this point, see Thompson, 1986).

3 In the English case in the mid-nineteenth century, property-owning men. 
juries frequently "notoriously mitigated the severities of the law by finding guilt of lesser crimes than those charged, where these could lead to the death penalty, and often showed a propensity to side with those accused of social crimes" (Pole, 2002: 102). The power of nullification - where a jury "refuses to follow the law and convict in a particular case even though the facts seem to allow no other conclusion but guilt" (Weinstein, 1992: 239) - remains part of the arsenal of Anglo-American juries, a power secured in both contexts through acts of resistance within the courthouse to the exercise of authoritarian control. ${ }^{4}$

\section{Systems and Outcomes}

In the civil law tradition, however, the cultural projection of justice is rather different. In such systems, fairness is imagined in the criminal procedure as centralized codification: as equality, rationality, professionalization, and the elimination of error. Where juries are therefore central to the common law projection of justice, they are much less significant in the civil law tradition. In France, for example, juries are only present in major criminal cases ("crimes," defined by prospective sentences of at least ten years in prison), judged in cours d'assises, and even then the jury of twelve includes the three sitting magistrates. Less serious offences ("délits") are held in tribunaux correctionnels before a magistrate, normally accompanied by two assessors, or for very minor offences carrying no possibility of a custodial sentence ("contraventions"), in tribunaux de police, again before a magistrate. ${ }^{5} \mathrm{Of}$ cases brought to court in France in 2008, only 0.4 percent concerned crimes; the vast majority, 92.2 percent, concerned délits (Timbart, 2009). In contrast, the thresholds for accessing a jury trial are far lower in England and Wales. Here, again, there are three broad categories of offence: summary, tried by bench, in a Magistrates court; indictable, tried by jury in a Crown court; and "either way" offences, where defendants can elect to be committed for trial by jury in a Crown court. This last category includes theft, robbery, some forms of trespass, and under the 1971 Criminal Damage Act, criminal damage of an estimated value in excess of $£_{5}, 000$. This charge is faced frequently by direct action protesters.

4 See Barkan (1983) for a discussion of the restraints placed on nullification in the United States.

5 A similar hierarchy operates in Belgium. 
The differential effects of juries on trial proceedings are perhaps most visible in trial outcome data. In England and Wales, juries produce acquittals in criminal cases more frequently than magistrates sitting alone. Conviction rates in Magistrates courts are traditionally high: for summary offences dealt with in these courts in 1999, only 2.2 percent produced not guilty verdicts after trial. In contrast, for indictable offences which came to trial in Crown courts (i.e., where defendants pleaded not guilty), 62 percent were acquitted (Auld, 2001, Appendix 4). More recent figures confirm this proportion: according to Ministry of Justice statistics, 64 percent of defendants who pleaded not guilty in cases dealt with in 2010 were acquitted, although only 28 percent of these were acquitted by the jury. ${ }^{6}$ The comparison is perhaps most relevant for either-way offences: of the 296,000 either-way cases tried by Magistrates courts in 1999, 11,00o resulted in acquittals (3.7 percent); in contrast, of the 56,00o either-way cases completed the same year after being committed to the Crown court for trial, 13,000 resulted in acquittal (23.2 percent) (Auld, 2001, Appendix 4). For a given criminal offence, therefore, the probability of acquittal is significantly higher when tried by jury rather than by bench.

In practice, therefore, where activists commit a criminal offence related to direct action - acts of trespass, criminal damage, theft, public order offences, and so on - there are structural differences between the type of trial that they can expect to face, and thus the composition and population of the court arena, depending on the judicial context. Indeed, for the type of offence likely to be committed by social movement actors, in civil law systems there is effectively no opportunity to make a case before a jury. ${ }^{7}$ The major difference is between a jury trial in the common law tradition with (in the broadest statistical terms) a significant possibility of securing an acquittal; and a bench trial in the civil law tradition, with a low probability

6 Of the rest, 62 percent were discharged by the judge, 8 percent were acquitted on the direction of the judge, and 1 percent were acquitted by other means (Ministry of Justice, 2011: 91).

7 It is of course possible that movement actors will commit serious violent crime. We have excluded "terrorist" offences from our discussion for reasons of space, but it is worth noting here that for a variety of reasons (the potential for jury intimidation, jury bias, the public dissemination of classified information), jury trials in such cases are considered problematic and defendants are often subjected to specific judicial regimes. In France, terrorist cases have been held in special assize courts without jury since 1986; in the United Kingdom, juries were suspended in Northern Ireland in 1973 (though not in the rest of the UK); in the United States, juryless military tribunals were introduced in November 2001 for foreign nationals indicted on terrorist charges (though US citizens are tried before a jury); in Belgium, the right of defendants in "political trials" to be tried before a jury is constitutionally protected, but since 2003, "terrorist" trials are held without a jury in special assize courts. 
of acquittal. This probability is not nil, of course; magistrates in both civil and common law systems have on occasion demonstrated their own moral agency and capacity to produce relative innovation with respect to the law. However, Stengers argues that, in civil law systems especially, the concern for sécurité juridique - the security of the law - limits this, rendering this capacity for innovation necessarily weak (2004: 23-28).

Evidence comparing trials for criminal damage caused by anti-GMO "crop-trashers" in England and France supports this general hypothesis (Doherty and Hayes, 2012; 2014). In France, between February 1998 and January 2012, courts in 23 different towns heard 28 prosecutions, with 13 verdicts taken to appeal, with activists consistently pleading a "necessity" defense, arguing that their deliberate destruction of genetically engineered crops was designed to stop a greater harm. On three occasions magistrates did not convict, agreeing with the defendants that they had acted legitimately out of necessity, and acquitting them. On a further occasion, at Poitiers in June 2011, defendants were discharged after the trial was nullified for procedural reasons. On each of these four occasions, the decision was subsequently overturned on appeal. In other words, on each occasion, trial has resulted in conviction, either on initial hearing or on appeal.

Comparison with the fate of defendants tried for similar actions in England proves instructive. Most notoriously, Greenpeace UK destroyed a field of GM crops at Lyng in Norfolk in 1999; all 28 activists were twice acquitted at Norwich Crown Court the following year. Only one jury trial of "crop-trashers" produced a conviction (in 2003, for an action in 2001); the two activists found guilty received fines. This is in line with a broader pattern in England where over the previous ten years, prosecutions of protesters against new roads, incinerators and nuclear, chemical and arms trade companies frequently produced acquittals on the basis of lawful excuse defenses. In 2000-2001 the Crown Prosecution Service lost three major trials against anti-GMO activists, and this trend has carried on since the scaling-down of such activism: English juries have notably acquitted Greenpeace climate change activists at Maidstone Crown court in 2008, peace campaigners at Bristol Crown court in 2007 (for damaging US B-52 bombers at Fairford airbase in 2003, prior to the Iraq War) and at Brighton Crown court in 2010 (for breaking into and damaging the premises of EDO, a defense equipment manufacturer that had supplied the Israeli army).

For movement actors on trial, a jury is of both instrumental and symbolic value: the jury's capacity for moral agency seemingly increases the probabilities of a successful outcome (here, measured as acquittal); equally, the jury's socially representative function means that activists may state 
their case in front of citizens representing the democratic community as a whole. For example, in the September 2008 trial of the "Kingsnorth Six," six Greenpeace activists who had broken into a coal-fired power station in Kent, England, were cleared of causing $£_{30}, 000$ of criminal damage by the majority verdict of a jury at Maidstone Crown court. The acquittal was won after the defendants claimed "lawful excuse" under the ${ }_{1971}$ Criminal Damage Act, in what became widely known as the first "climate change defense" (Hilson, 2010). Following the verdict, one of the defendants argued that

This verdict marks a tipping point for the climate change movement. When a jury of normal people say it is legitimate for a direct action group to shut down a coal-fired power station because of the harm it does to our planet, then where does that leave Government energy policy? We have the clean technologies at hand to power our economy. It's time we turned to them instead of coal. ${ }^{8}$

In contradistinction, in April 2009, 114 activists were arrested in Nottingham, England, for "conspiracy to commit aggravated trespass" by planning to shut down a coal-fired power station at Ratcliffe-on-Soar, leading to two trials, of 20 activists in December 2010 and a further six, in January 2011. In the first trial, the activists, pleading lawful excuse, were found guilty (unanimously) by the jury, but given a mixture of small fines, conditional discharges, and unpaid community service sentences by the judge, who underlined their sincerity, commitment, and courage; the second prosecution collapsed when it was revealed on the eve of the trial that one of the activists was an undercover police officer, who had agreed to testify in favor of the defendants. One of the defendants initially found guilty in the first trial argued that in failing to convince a jury, they had failed a "revealing litmus test": 9

The jury received a more extensive education on climate change than most people get in a lifetime. That they could not vindicate our actions is nothing to get self-righteous about; it is deeply disturbing. If the jury,

8 Michael McCarthy, "Cleared:Jury Decides That Threat of Global Warming Justifies Breaking the Law." The Independent, 11 September 2008.

9 Rob Evans and Paul Lewis, "Ratcliffe-on-Soar Activists Furious as No Disciplinary Charges Brought over Withheld Tapes." The Guardian, 5 April 2012. 
after everything they had heard, couldn't bring themselves to sympathise with our actions, who will? ${ }^{10}$

Juries are thus important players within the court arena as they are potentially receptive to ideas of justice that exceed the justice that is limited to the letter of the law.

\section{Legal Culture and Court Operation}

This does not tell the whole story, however. Verdict possibilities are dependent on the contingent availability in law of certain defenses, such as that of "lawful excuse." And, beyond verdict probabilities, more complex are the effects that the presence of juries has on the organization and operation of the court arena. Civil law criminal procedure is inquisitorial and predominantly bureaucratic: the judge leads the questioning, with the role of lawyers for each side being to suggest to the judge the existence of certain problems or evidence, and to make a closing argument. The judge may retain witnesses until satisfied with their testimony; there is no crossexamination of defendants by counsel. As Spencer (2002) notes, the broad distinction between "inquisitorial" civil law and "adversarial" common law criminal procedures is over-stated. Yet, in the common law system, criminal procedure is essentially composed as (melo)dramatic performance, structured by rhetorical combat between defense and prosecution counsel, with the jury's verdict providing a theatrical climax. Carrington (2003: 92) points out that a key aspect of jury trials is the oral nature of the conduct of the trial, itself fundamental to the construction of the trial as "a dramatic and not a bureaucratic event." ${ }^{\prime 11}$

The role of the judge in common law jury trials is formally that of a neutral arbiter. Yet the judge has two important powers: directing the jury through summing up, and acting as a gatekeeper, with the capacity to prohibit the defense from submitting certain forms of evidence to the court. Two cases are illustrative of this power. In July 2009, 29 climate activists were prosecuted at Leeds Crown court in England under the 1861 Malicious Damage Act, for obstructing a train carrying coal to the Drax power station

10 Bradley Day, "The Climate Movement Is in Desperate Need of Renewal." The Guardian, 5 January 2011.

11 This is, of course, the foundation for the jury trial as a staple of the plots of novels, plays, films, and multiple TV series. 
in North Yorkshire the previous year. ${ }^{12}$ Because they were prosecuted under the 1861 Act rather than the 1971 Criminal Damage Act, the defendants had no entitlement to make a "lawful excuse" defense; instead, they sought to make a "necessity" defense, potentially available to defendants facing any criminal charge (Schwarz, 2010). However, the judge in this case ruled that the defendants were not allowed to mount a necessity defense based on climate change, effectively disbarring them from calling expert witnesses. ${ }^{13}$ Unable to present the defense they had planned, the defendants were resigned in advance to being found guilty by the jury. The trial's dramatic potential, and media and political impact, were minimized. ${ }^{14}$

The second case is United States v. DeChristopher, from another common law tradition. DeChristopher was sentenced in June 2011 to a two-year prison sentence in California for a climate change action in Salt Lake City in December 2008, for disrupting a federal auction of oil and gas drilling rights in south Utah by pretending to be a bona fide bidder. Offered pre-trial mediation, DeChristopher refused, choosing to put his case before a jury, arguing that

As citizens have been squeezed out of the political process in general, the role of citizens in our legal system has been minimized, and power has been concentrated into the hands of judges and into government officials.... And I wanted to put the power in the hands of citizens rather than in the hands of government officials. ${ }^{15}$

The trial judge, however, refused to let DeChristopher put forward a political necessity defense, arguing that in cases of so-called "indirect" civil disobedience - where action breaks not the contested law itself, but only a circumstantially related one (DeChristopher's action did not break the law enabling the state to auction land permits, but rather the laws against false representation) - a defendant has no grounds to present such a defense. The judge's decision is consistent with the jurisprudence set by a 1992 ruling of the Ninth Circuit, in United Sates v. Schoon, regarding the prosecution of activists who staged a protest against US policy in El Salvador by illegally

12 Seven pleaded guilty; the trial was thus of the 22 activists who pleaded not guilty.

13 Though the judge did in fact allow two defendants to discuss climate change during their own testimony.

14 Discussion with two Drax defendants, March 2012.

15 Jason Mark, "Tim DeChristopher Speaks about His Impending Prison Sentence." 14 June 2011, http://www.earthisland.org/journal/index.php/elist/eListRead/ tim_dechristopher_speaks_about_his_impending_prison_sentence. 
entering the IRS offices in Tucson, Arizona, in December 1989. Prior to this ruling, activists had regularly been successful in US state courts (on issues such as US policy in Central America, nuclear power and weaponry, apartheid, the politics of the CIA), winning jury acquittals or having charges dropped (Cavallaro, 1993: 361-362). Unable to explain why he broke the law, DeChristopher was found guilty in March 2011 by the unanimous verdict of a jury able to hear the details of the offences, but not the motivations for committing them.

\section{The Tactical Choices of Movement Players}

Attention to criminal justice systems enables us to identify reasonably stable, long-term properties affecting the organization and operation of trial proceedings, which differ between state (and even sub-state) context, and which produce a balance of probabilities of trial outcomes for social movement players subjected to these proceedings. However, these properties, though (axiomatically) subject only occasionally to renegotiation and change, are also a site of strategic interaction, adversarial negotiation, and discursive contest, undertaken by state and non-state players seeking to maximize their political advantage within the court arena.

Defendants in criminal trials are faced with a profound power imbalance, which governs not just the potential outcomes, but also the terms of their appearance in court. The decision whether and whom to prosecute, and the terms of the indictment, are the preserve of the public prosecutor. These decisions may have powerful material effects on the defendants, dividing groups (when some are prosecuted and others not), excluding some defenses and allowing others, configuring arenas with or without juries, and permitting or denying players to go to trial.

For movement players faced with this power imbalance, the most fundamental decision is whether to recognize or reject the authority of the court. For example, considering trials a propaganda opportunity, in 1905 Lenin instructed members of the Russian Social Democratic Labor Party to represent themselves in court and challenge the legitimacy of the trial process. This model was subsequently developed by French communist lawyers representing combatants in post-war decolonization struggles in Africa. Most famously, in the 1957 trial of four members of the Front de Libération Nationale (FLN) accused of participating in a bombing campaign in Algiers, defense lawyer Jacques Vergès developed a défense de rupture, using the trial to challenge the legitimacy of the state, refusing courtroom 
codes, and turning the judicial process into a political event located outside the courthouse (Israël, 2009: 63-71). More counterculturally, the defendants in the Chicago Eight conspiracy trial systematically violated the court's ceremonial codes of deference and demeanor, acting in a fashion "consistent with their self conceptions as revolutionaries" and "actively assert[ing] the validity of their values over those of the court and the wider society it represents" (Antonio, 1972: 295).

Such "rupture" defenses are relatively rare, anti-colonial, revolutionary and terrorist movements excepted (de Graaf et al., 2013). Few trials of movement actors involve explicit attempts to undermine the authority of the court in this way. Defendants therefore have to decide how to engage in the arena of the court tactically as players. Given that those indicted as movement players invariably believe that their own actions are legitimate, the strategic dilemma that they typically face is between maximizing their chances of acquittal, by exploiting the opportunities provided by the legal system, and prioritizing the presentation of their action as authentic, irrespective of the effects this will have on the legal outcome. The choice between these strategies can vary even within the same compound group of players.

For example, during the mid-1980s, there were hundreds of trials of women from the anti-nuclear peace camp at RAF Greenham Common in Berkshire, set up to protest the deployment of Cruise missiles in the UK. Rather than seeking an acquittal, the Greenham women often adopted symbolic defenses, stating their case in court by citing international law or their own personal experience. However, if the opportunity arose to expose inconsistencies (or downright lies) in the evidence of police or others, and gain an acquittal, most took it. Defendants typically refused to conform to the hierarchies of court decorum: supporters in the gallery frequently interrupted proceedings, humming or singing when the police were giving evidence. More than anything, the process was unpredictable. The court officials had no way of knowing if a defendant would plead guilty so that the case was over fast (which the defendants might do if, for example, they needed to be somewhere else the next day); or whether they would plead not guilty, calling expert witnesses, effectively making the trial last several days. As time went on, more women chose to defend themselves, partly as a matter of resources (because applications for legal aid were refused), partly as a matter of political strategy (because it gave them more freedom to speak). Having themselves attended so many trials as one type of player (supporters, defendants), they thus became able to act as other types 
of player, becoming experts in cross-examination and court procedure, learning rules and gambits (Roseneil 1995: 253-259).

Securing access to particular arenas can be the subject of tactical battles in themselves. For example, in England in the late 1990s and early 200os, anti-GMO activists waged a battle with the Crown Prosecution Service over access to jury trials: as an activist newsletter reported, "The Crown became somewhat reluctant to press for damages of over $£_{5}, 000$ because this gives activists the right to ask for a trial by jury rather than a magistrate. ${ }^{{ }^{116}}$ Prosecutors would claim that there had been hardly any damage; campaigners would claim that they had in fact caused plenty, in order to try to get a jury trial.

In France, Les Déboulonneurs commit regular, open and public direct action against billboards, seeking to impose a maximum size of $40 \mathrm{~cm} \mathrm{x}$ $30 \mathrm{~cm}$ on commercial advertising posters. For the group, which is based in a handful of French cities but mobilizes relatively few core activists, being prosecuted is a strategic aim. Yet the complaint of many activists is that they are unable to get themselves prosecuted; often, they can't even get themselves arrested. ${ }^{17}$ Since 2005, activists have undertaken over 40 actions in Lille and over 50 in Paris; nationally, only about 1 in 15 actions has produced a prosecution. The tactical choices made in the knowledge that action would lead to arrest and thence to trial could thus be undermined by operational decisions made by police not to arrest, and state prosecutors not to pursue the case.

Tactical conflict between players therefore centers on liability, and on the configuration of and access to the judicial arena. In relation to this we can distinguish between three common strategic approaches by movement players: (1) where the trial is anticipated and planned for as an end in itself, as in the Plowshares anti-nuclear movements; (2) where activists seek to avoid arrest, but once arrested adapt their strategy to maximize the opportunities available in the legal arena, such as animal rights or radical environmental activists prosecuted for acts of sabotage; (3) an intermediate position in which individuals adopt a pragmatic position that varies according to the kinds of action taken, since in some cases arrest is to be expected (as in site occupations) whereas in others (such as covert crop trashes) it might be avoided. For the first of these types of group, preparation for trials is typically much more codified by movement traditions than for the other groups.

What is at stake for all those prosecuted in cases of citizenship crimes is precisely the symbolic meaning of acts, their definition as criminal or 
lawful. We may surmise that defendants, where they engage with the trial process and seek to present a justification of their acts, will have four broad objectives: (1) to construct the social nature of their offence; (2) to broaden the focus of the indictment from its narrowly legal character (whether a given offence has been committed in law) to its political character (the reasons for the committal of the offence); (3) to thus engage the moral agency of the court's decisional players, and secure favorable outcomes within and outside the court space; (4) in so doing, to reveal the norms and dispositions underpinning the legal system as ideologically structured. Though tactically disadvantaged by the structure of the trial process, defendants can mobilize five sets of players in order to achieve these goals: the defendants themselves; their lawyers; the witnesses that they call; their supporters, inside and outside the courtroom; third parties, such as the media.

The number of players who are actual or potential opponents for movements facing prosecution is at least as numerous, including - within the court - judges, prosecutors, witnesses (usually including the police); and beyond the court: government ministers (whose role varies according to the structure of the political system), corporate actors, countermovements and once again, the media. The separation of powers may protect the judicial system from overt political interference but in direct action prosecutions, normal practice may be broken or suspended. For example, following the acquittal of Greenpeace UK activists at Kingsnorth in 2008 the energy company that owned the power plant lobbied the government to impose stiffer sentences on climate campaigners as a deterrent against similar protests. ${ }^{18}$ The 2009 Drax and 2010 Ratcliffe-on-Soar UK convictions of climate activists (discussed above) were overturned on appeal when it emerged that the rules of the legal process had been broken by the Crown Prosecution Service, which had failed to pass crucial evidence gathered by an undercover policeman to the defense. Thus, although often disguised by state secrecy, the state is not a unitary institution: tactical interaction between different players within the state and with other opponents of movements is evidently a material factor affecting trials for direct action crimes. Furthermore, abuse of process by the state, when discovered, causes major political damage to the authorities. ${ }^{19}$

18 James Ball, "E.ON Lobbied For Stiff Sentences against Kingsnorth Activists, Papers Show," The Guardian, 19 February 2013.

19 The success of activists and journalists as well as the bravery of police whistleblowers in exposing the work of undercover units that target political activists led the UK government to concede, reluctantly, the need for an independent inquiry into their role. 


\section{Social Crime and Event Construction}

As Vanhala points out, one of the main problems facing collective actors in the courts is that the justice system is "inherently individualistic," with legal process generally focused on "an individual with a concrete issue that requires a legal resolution" (2011: 12). Indeed, prosecution players can be expected to mobilize the rules of the arena to change the nature of their opponents, to transform compound players into simple players; a strategic challenge for activists is therefore to remain compound players. Securing a collective prosecution with its attendant possibilities of imposing costs on opponents and creating occasions for solidarity displays from supporters can itself be a goal of action. State players thus face potential decisionmaking dilemmas over arrest and charging that mirror the plight of the Déboulonneurs (above).

For example, the French Faucheurs Volontaires have adapted their tactics across multiple trials in order to anticipate the response of police to their field actions. This adaptation involves establishing, prior to undertaking an action, a set of common verbal responses for use under police questioning, in order to forestall prosecutors from differentiating leaders from followers (and thus differentiating between them in their own decision making, including whom to prosecute and on what charges). This tactic has proved increasingly successful for the Faucheurs, resulting in a series of significant collective trials. In the UK, recent guidance from the Crown Prosecution Service explicitly directs prosecutors toward identifying and prosecuting protest organizers, and thus targeting the most disruptive players (Bowcott, 2012). In the case of the 145 UK Uncut activists arrested by the police for occupying the Fortnum \& Mason's luxury store in Piccadilly, central London, in a corporate tax avoidance protest in March 2011, prosecutors singled out 30 for trial. This whittling down was undertaken on the basis that protesters were prosecuted if they were carrying megaphones, beach balls, or at least 20 UK Uncut leaflets at the time of arrest. The seeming arbitrariness of this distinction produced an absurd outcome: during the trial, one defendant was released without charge when it transpired that some of her leaflets were in fact theater ticket stubs, and she did not after all have the requisite number to be prosecuted.

Within the court arena, penalties are applied individually, according to role and motive; again, while magistrates and prosecution lawyers may aim to differentiate, defendants and defense lawyers can be expected to maintain the collective nature of responsibility. Equally, in order to establish the collective legitimacy of their action, defendants are foremost 
faced with socializing their action, whether by demonstrating community support, testifying to the integrity of their motives and the collective good of their objectives, or by mobilizing other players (supporters in the courthouse, moral witnesses). In their own testimony, defendants may seek to establish the ethical basis of their acts through the "moral presentation of self" (Schervish, 1984: 196), establishing their character, integrity, and biographical commitment to the cause, in the way that impressed the judge in the first Ratcliffe trial.

Whether players are individual or compound players, and what type of compound players, therefore emerges as a strategic outcome of the trial process. We may expect that, especially where defendant players have deliberately courted prosecution, socializing crime is both a key symbolic aim and embedded in the original strategic planning of illegal action. For example, in the Lyng anti-GMO action for which 28 activists were tried in Norwich, Greenpeace deliberately sought to replicate the social representativity of the trial jury by constructing the activist group as a cross-section of the general public (in age, regional origin, gender and social background). ${ }^{20}$ In the trial of 62 French anti-GMO activists in Colmar in September 2011, the defendants similarly aimed to be representative of the French population as a whole. ${ }^{21}$ In Belgium, where 11 activists were prosecuted in January 2013 on charges of organized criminality for having destroyed a field of genetically modified potatoes in May 2011, the Field Liberation Movement consciously foregrounded the presence of Dutch-speaking activists, while adopting the tactic of self-indictment from the French Faucheurs Volontaires in order to build solidarity outside the courthouse; 80 supporters signed an affidavit demanding to be placed on trial alongside the defendants. ${ }^{22}$

Defendants may also typically be expected to attempt to shift the focus from the defense of their own actions to the "prosecution" of their opponents, as the case of the December 2010 trial in Caen, France, of six anti-nuclear activists demonstrates. The previous month, the activists had physically blocked a train carrying vitrified nuclear waste traveling from Valognes in Normandy to Gorleben in Germany, using what is now the routine practice of chaining themselves to the rail track and to each other. Throughout the trial, the prosecution and defense were constantly engaged in a contest to define the process: the prosecution sought to restrict debate

20 Discussion with Greenpeace defendant, Stafford, June 2008.

21 Discussion with three Faucheurs Volontaires activists, Ghent, May 2011. Note that in neither case did social representativity involve ethnic diversity.

22 Discussion with FLM defendants, Brussels, July 2011. 
to the bare facts of the action (themselves uncontested by the defendants), and thus to depoliticize the legal process; the defense sought to generalize, to draw the debate into political terms, establishing their motivation as democratic, asserting the contradiction between a nuclearized society and participative citizenship:

C.: Our goal is to create a real debate about nuclear power, the public has never been consulted.

State prosecutor: It's not in court that that type of debate can take place, but within the democratic organs of society. You are here to be judged for your actions, not to make the world anew.

C.: That's exactly why I am here. ${ }^{23}$

The capacity of defendants to make these arguments is heavily dependent upon the gatekeeping role of the judge, who as a player in the court arena has scope for discretion. In the September 2011 Colmar trial, the presiding magistrate gave the floor to each defendant in turn to explain the reasons why they had participated in the destruction of a scientific trial of genetically modified vine roots at the French National Agricultural Research Institute's (INRA) local research facility the previous summer. In contrast, during the trial in Bobigny, France, in July 2012 of one environmental activist for having trespassed onto the runaway at Charles de Gaulle airport and stood in front of an Airbus the previous month in a protest against global warming, the presiding magistrate refused to let the defendant explain the motivations for his actions, bringing the defendant's testimony to an abrupt close. ${ }^{24}$

In trials for direct action crimes, the witnesses called by the defense are particularly important in providing "expert" testimony as scientific or moral authorities (Hayes, 2013). As we have seen in the Drax and DeChristopher cases, this is again heavily dependent upon both the gatekeeping role of the magistrate and of previous judicial decisions. Given the public and contestatory nature of trials, it is perhaps unsurprising that Jasanoff sees "expert" testimony by scientists (where it is allowed) as a privileged site of co-production, of the public socialization of scientific knowledge (2004:3). For Lynch, criminal cases can "provide vivid public tutorials on the flexible and contentious way in which parties negotiate the boundaries between science and non-science, and expert and non-expert knowledge" (2004: 165). Thus in the Kingsnorth and Ratcliffe climate change trials, defendants 
sought to substantiate a lawful excuse defense by calling expert testimony, arguing that their action prevented a greater harm. Climatologist James Hansen, Director of NASA's Goddard Institute for Space Studies, testified in court in both cases that accelerating coal use in the new century is "a prescription for planetary disaster," concluding that this "would leave a reasonable person to take steps to urgently and deeply cut $\mathrm{CO}_{2}$ emissions. ${ }^{25}$

Typically therefore, defendants stress their biographical and ethical commitment, underline the social nature of their action in various ways, and mobilize other players to contextualize and legitimize their action or deliver a public pedagogy. This will be particularly important where defendants seek to mount a necessity or lawful excuse defense. But the importance of these tactics is not limited to the courtroom; rather, it is also a communicational strategy outside the courthouse.

Media coverage is crucial in this respect. Protesters need media coverage to be able to reach beyond the audience in the court and their existing supporters. Ideally, for social movement actors, a trial will create a dramaturgy that will end with their vindication (through an acquittal), a demonstration of their commitment to the cause, and the wide publicization of their arguments. Conviction and harsh penalties may alternatively work to increase solidarities within and beyond the core movement group. However, even when the media play their part in this drama by sending reporters, their increasingly limited time and resources means that most media organizations only cover the first and last days of the trial. These are the worst days from the activists' perspective, since the first day is when the prosecution generally makes its case and the last day is when the verdict is given. The time in between, when activists give evidence and make their case, is the least likely to be reported.

\section{Conclusion: Strategic Interaction in the Court Arena}

There is perhaps no greater symbol of the power and purpose of the state than the criminal law, its procedures, processes, institutions, and personnel. As an arena, the criminal law functions to articulate, adjudicate, and discriminate: it defines and announces prohibited conduct; it assesses liability for transgression; it constructs hierarchies of harm and culpability (Robinson, 1994). By its very definition, it patrols and polices the boundaries

25 James Hansen, witness statement to trial of Ratcliffe activists, Nottingham Crown Court, September 2010. 
of the dominant social and political order, and it sets the terms of the inclusion and exclusion of the citizenry within or from that order. Again by definition, when movement players oppose the specific or general terms of the social and political order, this brings them into the arena of the criminal law. But the courthouse is also an institutional arena in which various state (judge, prosecution, and police) and non-state players (lawyers, defendants, witnesses, civil parties, juries, media, even members of the public) come into direct discursive contact within the rules of engagement set by the law, by judicial procedure and process, and by the cultural organization of participation in this process. And as we have seen, it is also a site of the production of meaning in other senses, including of political challenge, and of the interplay of rational-legal justice with the "natural" justice of the jury.

We aim to stimulate further interest in the relationships between social movements and criminal justice, arguing that it is a vital area of collective action which has been curiously neglected in the literature until now. As readers will have noticed, our focus here is very much on Western democracies, and we recognize that this does not address the major gap in the study of prosecutions of activists in other political and judicial systems. Clearly, to take perhaps the most high-profile trial of activists of recent times, the enormous international attention given to the Pussy Riot trial in Russia in 2012 indicates the potential for taking the study of trials of direct action into non-Western and authoritarian settings. We hope this lacuna will rapidly be addressed.

Beyond this general goal, we make two specific arguments. The first is that, for criminal justice systems, we can identify stable, long-term, predictable terms of engagement set by formal rules of procedure which are different from system to system; that these rules are the subject of political and discursive engagement between players aiming to secure the most favorable terms within this arena; that the outcomes of this engagement will be central to our understanding of the outcomes of criminal prosecutions, in terms of both their judicial impacts (the verdicts handed down) and their political impacts (crucially, setting the terms of meaning of the criminal prosecution).

The second argument is that criminal trials are complex processes which cannot a priori be reduced the simple imposition of authority by a unified state. We know that arrest and trial "can energize and elevate movements, increasing their support and chances of success" (Goldstone, 2004: 356; see also Koopmans, 2004: 29); we should at the very least note how prosecution enables solidarity and collective identity reinforcement processes. This is not to say that the courthouse is not also a theater of symbolic state power: 
the rules of the game are set by state players, activists are rarely able to master the terms of engagement, arrest and trial are stressful events which impose financial, psychological, and emotional costs, irrespective of the court's verdict, and can have strong negative as well as positive effects on both intra-group solidarities and the capacity of movement players to wage campaigns, and we should certainly be wary of casting them as necessarily beneficial or productive episodes for challenging actors. As one Belgian anti-GMO activist put it to us à propos of being taken to court in 2004 for crop-trashing, "it's heavy, it's tiring, it destroys your life for years," "it's only when you're in it that you begin to realize what the consequences are," "you end up on the stand when you should be in a field." Yet the same activist also described the trial as "a miracle"; "we won, and sparked off a public debate. ${ }^{26}$ Beyond the multiple anecdotes provided by particular cases, criminal prosecutions hold our attention because they are normative crucibles in which the challenge to the dominant social and political order can be made by collective social actors. These players make tactical choices to use the possibilities presented by the arena of the courthouse to level political as well as legal challenge. Occasionally, they even succeed.

\section{References}

Andersen, Ellen Ann. 2005. Out of the Closets and into the Courts: Legal Opportunity Structure and Gay Rights Litigation. Ann Arbor: University of Michigan Press.

Antonio, Robert J. 1972. "The Processual Dimension of Degradation Ceremonies: The Chicago Conspiracy Trial: Success or Failure?” British Journal of Sociology 23: 287-297.

Auld, Lord Justice. 2001. Review of the Criminal Courts of England and Wales, http://webarchive. nationalarchives.gov.uk/+/http://www.criminal-courts-review.org.uk/auldconts.htm.

Barkan, Steven. 1983. "Jury Nullification in Political Trials." Social Problems 31: 28-44.

-. 2006. "Criminal Prosecution and the Legal Control of Protest." Mobilization 11: 181-194.

Bedau, Hugo. A. 1991. "Introduction.” In Hugo A. Bedau, ed., CivilDisobedience in Focus. London: Routledge.

Bowcott, Owen. 2012. "Pursue Masked Protesters More Vigorously, CPS Says." The Guardian, 6 March.

Carrington, Paul D. 2003. "The Civil Jury and American Democracy." Duke Journal of Comparative \& International Law 13: 79-94.

Cavallaro, James L. Jr. 1993. "The Demise of the Political Necessity Defense: Indirect Civil Disobedience and United States v. Schoon." California Law Review 81: 351-385.

De Fazio, Gianluca. 2012. "Legal Opportunity Structure and Social Movement Strategy in Northern Ireland and Southern United States." International Journal of Comparative Sociology $53: 3-22$. 
De Graaf, B.A., et al. 2013. The Anders Behring Breivik Trial: Performing Justice, Defending Democracy. The Hague: International Centre for Counter-Terrorism.

Dinos, Jacques, and Marcel Gibelin. 1986. June '36: Class Struggle and the Popular Front in France. Trans. Peter Fysh and Christine Bourry. London: Bookmarks.

Doherty, Brian, and Graeme Hayes. 2012. "Tactics, Traditions, and Opportunities: British and French Crop Trashing Actions in Comparative Perspective." European Journal of Political Research 51: 540-562.

-. 2014. "Having Your Day in Court: Judicial Opportunity and Tactical Choice in Anti-GMO Campaigns in France and the United Kingdom." Comparative Political Studies 47:3-29.

Epp, Charles R. 1998. The Rights Revolution:Lawyers, Activists, and Supreme Courts in Comparative Perspective. Chicago: University of Chicago Press.

Falk, Barbara J. 2008. "Making Sense of Political Trials: Causes and Categories." Occasional Paper 8, Munk Centre for International Studies, University of Toronto.

Goldstone, Jack A. 2004. "More Social Movements or Fewer? Beyond Political Opportunity Structures to Relational Fields." Theory and Society 33: 333-365.

Hay, Douglas, et al. 2011. Albion's Fatal Tree: Crime and Society in Eighteenth-Century England. Revised ed. London and New York: Verso.

Hayes, Graeme. 2013. "Negotiating Proximity: Expert Testimony and Collective Memory in the Trials of Environmental Activists in France and the UK." Law \& Policy 35: 208-235.

Hilson, Chris. 2002. "New Social Movements: The Role of Legal Opportunity." Journal of European Public Policy 9: 238-255.

-. 2010. "Climate Change Litigation: An Explanatory Approach (Or Bringing Grievance Back In)." In Fabrizio Fracchia and Massimo Occhiena, eds., Climate Change: La Riposta del Diritto. Naples, IT: Editoriale Scientifica.

Hobsbawm, Eric J. 1969. Bandits. London: Weidenfield \& Nicolson.

Israël, Liora. 2009. L'Arme du droit. Paris: Presses de Sciences-Po.

Jasanoff, Sheila. 2004. “The Idiom of Co-Production." In Sheila Jasanoff, ed., States of Knowledge: The Co-Production of Science and Social Order. London: Routledge.

Koopmans, Ruud. 2004. "Protest in Time and Space: The Evolution of Waves of Contention." In David Snow, Sarah A. Soule, and Hanspeter Kriesi, eds., The Blackwell Companion to Social Movements. Oxford: Blackwell.

Kunstler, William K. 1969. "Jury Nullification in Conscience Cases." Virginia Journal of International Law 10: 71-84.

Law Commission for England and Wales. 1989. Criminal Law: A Criminal Code for England and Wales, Vol. 1 (Law Com N ${ }^{\circ}$. 177). London: HMSO.

Lea, John. 2002. Crime \& Modernity: Continuities in Left Realist Criminology. London, Thousand Oaks and New Delhi: Sage.

Linebaugh, Peter. 2011. "Reflections." In Douglas Hay et al., eds., Albion's Fatal Tree: Crime and Society in Eighteenth-Century England. Revised ed. London and New York: Verso.

Lynch, Michael. 2004. "Circumscribing Expertise: Membership Categories in Courtroom Testimony." In Sheila Jasanoff, ed., States of Knowledge: The Co-Production of Science and Social Order. London: Routledge.

McCann, Michael W. 1994. Rights at Work:Pay Equity Reform and the Politics of Legal Mobilization. Chicago: University of Chicago Press.

Melucci, Alberto. 1985. “The Symbolic Challenge of Contemporary Movements." Social Research 52: $789-816$.

Ministry of Justice. 2011.Judicial and Court Statistics 2010, http://www.justice.gov.uk/downloads/ statistics/courts-and-sentencing/judicial-court-stats.pdf. 
Pole, J. R. 2002. “'A Quest of Thoughts': Representation and Moral Agency in the Early AngloAmerican Jury." In John W. Cairns and Grant McLeod, eds., The Dearest Birth Right of the People of England: The Jury in the History of the Common Law. Portland, OR: Hart.

Rawls, John. 1991. "Definition and Justification of Civil Disobedience.” In Hugo A. Bedau, ed., Civil Disobedience in Focus. London: Routledge.

Robinson, Paul H. 1994. "A Functional Analysis of Criminal Law." Northwestern University Law Review 88: 857-913.

Roseneil, Sasha. 1995. Disarming Patriarchy. Buckingham: Open University Press.

Rule, John. 1997. "Social Crime in the Rural South in the Eighteenth and Early Nineteenth Centuries." In John Rule and Roger Wells, eds., Crime, Protest and Popular Politics in Southern England, 1740-1850. London: Hambledon Press.

Sarat, Austin, and Stuart A. Scheingold. 1998. "Cause Lawyering and the Production of Professional Authority: An Introduction." In Austin Sarat and Stuart A. Scheingold, eds., Cause Lawyering: Political Commitments and Professional Responsibilities. Oxford: Oxford University Press.

—. 2005. "The Dynamics of Cause Lawyering. Constraints and Opportunities." In Austin Sarat and Stuart A. Scheingold, eds., The Worlds Cause Lawyers Make: Structure and Agency in Legal Practice. Stanford: Stanford University Press.

Scheingold, Stuart A. 2010. The Politics of Rights: Lawyers, Public Policy and Political Change, $2^{\text {nd }}$ ed. Ann Arbor: University of Michigan Press.

Schervish, Paul G. 1984. "Political Trials and the Social Construction of Deviance." Qualitative Sociology 7: 195-216.

Schwarz, Mike. 2010. "The Drax 29 and the Kingsnorth 6: Different Defences, Different Outcomes." ELFLine, Spring/Summer.

Spencer, J.R. 2002. "Introduction." In Mireille Delmas-Marty and J. R. Spencer, eds., European Criminal Procedures. Cambridge: Cambridge University Press.

Stengers, Isabelle. 2004. "Une pratique cosmopolitique du droit est-elle possible? Entretien avec Laurent de Sutter." Cosmopolitiques 8: 14-33.

Thompson, Edward P. 1975. Whigs and Hunters. London: Penguin.

-. 1986. "Subduing the Jury." London Review of Books, 18 December.

Tilly, Charles. 1978. From Mobilization to Revolution. New York: McGraw-Hill.

-.1995. Popular Contention in Great Britain, 1758-1834. Cambridge, MA: Harvard University Press. Tocqueville, Alexis de. 1961. De la Démocratie en Amérique, Tome 1. $12^{\text {th }}$ ed. Paris: Gallimard.

Vanhala, Lisa. 2011. Making Rights a Reality? Disability Rights Activists and Legal Mobilization. Cambridge: Cambridge University Press.

Weinstein, Jack B. 1992. “Considering Jury 'Nullification': When May and Should a Jury Reject the Law to do Justice." American Criminal Law Review 30: 239-254. 



\title{
$2 \quad$ Political Parties and Legislators
}

\author{
A Latin American Perspective ${ }^{1}$
}

Hélène Combes

In 1997 the coca-leaf growers movement, with Evo Morales at its head, became a political party: the Movement for Socialism - Political Instrument for the Sovereignty of the Peoples (MAS-IPSP). This development was in keeping with the heritage of miners unions and the indigenous mobilizations of the 1990s in Bolivia. (Do Alto and Stefanoni, 2006) ${ }^{2}$

While Brazil was still under dictatorship, trade unionists (particularly from the metallurgical sector), the urban movement in working-class neighborhoods, student activists, academics and so on came together to form the Workers' Party (PT), the great promoter of participatory budgeting in the 1990 s and the spearhead of the Latin American left and the World Social Forum. (Keck, 1992; Rocha, 2011)

In 1988, three years after the Mexico City earthquake, the Asamblea de Barrios housing rights association decided to symbolically field a candidate in the presidential elections. It chose "Superbarrio," the movement's champion and mascot (Cadena-Roa, 2002; Sánchez, 2004), a wrestler who defends those living in sub-standard housing and fights the IMF, the World Bank, government credit agencies, and so on. As the left slowly united behind Cuauthémoc Cárdenas, "Superbarrio" withdrew from the campaign and supported his candidacy. In 1989, "Superbarrio" and his activists participated in the foundation of the Party of the Democratic Revolution (PRD). The leaders of the Asamblea de Barrios played a fundamental role there throughout the 1990s. (Combes, 2011)

"Though her eldest son will soon turn 20, Rosa is a still young woman. White, with a long chestnut braid and a lively sense of humor, Rosa could be any other Paraguayan peasant. But Rosa presented herself as a candidate in the

1 Translated from the French by Ethan Rundell. I would like to thank James Jasper and the anonymous reviewers of this article for their commentaries and suggestions for further reading. 2 In their typology of Latin American left-wing parties, Steven Levitsky and Kenneth Roberts classify the MAS as a "Movement Left" party (2011: 13). 
elections... Rosa is a leader of the Land Rights Organization, the country's leading peasant movement, and a member of Frente Guazú, under whose banner she ran for office." (Macías, 2012: 82)

So many different scenarios ${ }^{3}$ : social movements and trade unions transforming themselves into parties, social movement activists and leaders creating parties or joining already existing ones. ${ }^{4}$ In the countries of Latin America, the cycles of mobilization against dictators and, later, for indigenous rights and against neoliberalism (Petras and Veltmeyer, 2011; Almeida, 2010) redrew the partisan political landscape. In European countries, many "new social movement" activists joined the ranks of left-wing parties over the course of the 1970s. Later, ecological movements transformed themselves into political parties. These phenomena can help us to see the emergence of new party machines as the outcome of a cycle of mobilization or the transformation of parties under the impact of the mass entry of activists formed in social movements. In other cases, multi-positioned activists remain in the minority and have little or no impact on a party's internal operation.

Despite the extensive interaction between parties and social movements, few scholars have directly addressed the question of their relations and mutual entanglements (cf. Combes, 2011; Luck and Dechezelles, 2011; Goldstone, 2003; Van Cott, 2005). More often, research on particular actors mentions this interaction in passing (Gunter and Montero, 2002: 6). This absence of global analysis may be partly attributed to disciplinary compartmentalization (Sawicki and Siméant, 2010). While the party is a canonical object of political science, social movements were until the 1990s the almost exclusive preserve of sociology. These two actors were thus studied separately ${ }^{5}$ and gave rise to multiple approaches within each discipline. ${ }^{6}$ In his introduction to a book on the interaction between social movements, political parties, and states, Jack Goldstone (2003) thus did

3 See also the cases studied by Paul Almeida (2010) of movements in the cycle of mobilization against neoliberalism: Bolivia, Salvador, Nicaragua, Uruguay, and Ecuador. Almeida author speaks of "social movement partyism."

4 The guerillas who transformed themselves into parties could also be mentioned in this connection. Yet I will leave this case aside as it seems to raise different empirical and theoretical issues. Similarly, I will not here address the role of social movements in defining public policy, a configuration in which parties play the de facto role of intermediary.

5 For a good overview of the relationship between parties and social movements, see Van Cott (2005), as well as Goldstone (2003) and McAdam and Tarrow (2010).

6 Evidence of this compartmentalization can be found in an overview of two journals of reference, both of which first appeared in the mid-199os: Party Politics and Mobilization. Across 
not hesitate to write that the former had been little studied even though political parties and social movements cannot be understood independently of their intimate relationship.

How have scholars described the interactions between these multiple actors? Too often in the literature on parties, the interaction between parties and other activist organizations is presented as a one-way relationship of dependence. For Angelo Panebianco (1988), in analyzing a political party one must take its interactions with the "organizations of its environment" into account as these constitute one of two explanatory variables of "the map of organizational power." Panebianco identifies three types of interaction: (1) The party controls the organization; (2) The exchange is well-balanced:party and organization leaders alike profit, with each group needing resources from the other to maintain their respective organization; (3) The organization controls the party. The party needs the resources supplied by the organization in order to stay alive. Panebianco's extremely schematic typology was developed to analyze the interactions between a single party and type of organization (trade unions in the case of the British Labour Party, for example) and does not take complex relations between multiple actors into account.

Katz and Mair's $(1994,1995)$ classic work on the "cartel party" suggests that parties are disconnected from civil society, with the relationship between parties and SMOs presented as a thing of the past. For many authors, a party has been institutionalized when it is no longer open to "its environment." Beginning in the 196os, Huntington presented autonomy as a condition of an organization's institutionalization: that is, the degree of differentiation from other social groupings and methods of behavior. Together with systematicity (the degree of interdependence among different sectors), autonomy is one of two criteria identified by Panebianco for defining political party institutionalization. ${ }^{8}$ Later definitions of political party institutionalization tend to be in line with this dual heritage and thus present autonomy as a central criterion of institutionalization. However, specialists of political parties consider institutionalization to be a positive development (with non-institutionalized parties seen as inchoate or at

this period, one finds only about five articles addressing social movements in Party Politics and about ten addressing parties in Mobilization.

7 The other being the relationship between the various offices and bodies existing in the organization (Panebianco, 1988).

8 One of the few authors to hold that autonomy is not a necessary condition of institutionalization is Steven Levitsky, an expert on the Latin American Peronist Party. Levitsky (2003, pp.25-26) shows how an under-institutionalized party hierarchy and strong, yet informal, linkages to the "mass base" encourage a "combination of flexibility and endurance." 
risk). This particularly holds for countries, such as those of Latin America, undergoing a return to democratic rule: there is a "strong assumption in the democratization literature that party institutionalization is a vital ingredient of democratic consolidation" (Randall and Svåsand, 2002: 24) . Indeed, the institutionalization of parties - and, as a consequence, party systems - is seen as an essential element in the consolidation or stability of democracies. In this context, continued ties with SMOs, taken to be a sign of instability, are more often condemned than studied.

In the literature on social movements, it is important to differentiate between schools. For "new social movements theory," autonomy figures in the very definition of the social movement: autonomy, vis-à-vis the state but also vis-à-vis parties, is at the heart of the capacity to construct oneself as an actor. Much of the work on social movements in Latin America in the 1980 and 9os, when this theory was hegemonic, also conceived of these relations in terms of instrumentalization (Calderón, 1995: 27) and co-optation (Alvarez and Escobar, 1992; Alvarez, et al., 1998) and was characterized by a normative vision: simplifying things somewhat, parties were presented as the "bad guys," agents of co-optation that encouraged the demobilization of social movements.

For the "political process model," the relationship between parties and social movements is more or less directly factored into the framework of the structure of political opportunities (Tarrow, 1994). Kriesi et al. (1995) present the configuration of power in the political system as a decisive element in the development of social movements. Studying the democratizations of the Southern Cone, Patricia Hipsher (1998) holds that the relationship between parties and movements is one of two key factors that shape movements' capacity to put their demands on the agenda.

Kitschelt addressed the emergence of new parties from the perspective of the structure of political opportunities (1989). Van Cott (2005), who has worked on the transformation of Indian movements into political parties in South America, also draws upon an opportunity structure approach, in a systematic comparative analysis of the conditions of possibility for the transformation of social movements into political parties. ${ }^{9}$ By studying six national configurations, characterized by different ethnic cleavages, she sought to determine the factors that explain the transformation of indigenous movements into political parties in several Latin American countries during the 1990s. Though Van Cott's analysis concerns the specific case of ethnic movements, it offers more general perspectives for understanding 
the emergence of parties from social movements. Yet, despite the wealth of her analysis, which can in many respects be extended to other national configurations, Van Cott hardly mentions factors internal to movements or the transmission of activist know-how. As many critics have pointed out (Goodwin and Jasper, 1999), studying the structure of opportunities does not suffice for understanding the emergence of a movement or political party.

Another way of understanding relations between parties and social movements is to attend to the very large body of work produced by the resource mobilization and political process school concerning social movement institutionalization..$^{10}$ Doowon Suh defines this as "a process of social movements traversing the official terrain of formal politics and engaging with authoritative institutions such as the legislature, the judiciary, the state and political parties to enhance their collective ability to achieve the movement's goals" (Suh, 2011: 442). For her, it is a matter of a "collective strategic choice of an SMO" (443). For authors who study a particular mobilization cycle or movement, social movement institutionalization can also allow a movement to achieve its chosen objectives in pursuit of social and political change (Meyer, 2007) despite the fact that its co-optation or preemption by political elites can bring the cycle to an end (Piven and Cloward, 1977; Tarrow, 1994). ${ }^{11}$ The authors cited nevertheless insist on the consequences in terms of demobilization, the deradicalization of demands, a loss of identity or solidarity for the movement, and so on.

To sum up, the manner in which the relationship between political parties and social movements is discussed (presented here in necessarily incomplete and schematic form) suffers from two drawbacks. The first concerns the normative reading of "autonomy." For specialists of parties, the party/SMO relationship prevents institutionalization and, ultimately, democratic stability. For new social movements theory and, in a more qualified way, the resource mobilization and political process school, this relationship is linked to co-optation and demobilization: it endangers the movement itself since autonomy is part of the latter's definition. In both cases, their condemnations prevent scholars from properly analyzing the phenomena at play. The movements' players often individually or collectively interact with a variety of other players. These interactions mold some players. Indeed, players who belonged to different arenas and/or were opposed to one another can develop common interests and worldviews as 
well as relations of trust and friendship. These sometimes lead individual players to join an organization in another arena.

The second drawback stems from the methods employed and the macrosociological level of analysis. Mainstream scholarship on parties favors quantitative and comparative methods, with the object of investigation constructed in an a priori manner. For example, field work and ethnography are almost entirely absent from the articles published by the journal Party Politics since its creation in 1996. Moreover, relations between categories of actors are sometimes conceived without taking into account the multiplicity of interactions among players. The actors are not homogenous in geographic terms or in terms of their respective levels (local, regional, national). ${ }^{12}$

Research on institutionalization does not take sufficient account of the variety of arenas that are involved (e.g., issues of geography as well as the types of administration with which collaboration is established). Even if a party is in power at the local or national level, it is also important to understand the differences between the party as an organization and the administrative logics in interactions with social movements. But the main analytical problem with this approach is that it considers the movement as a collective and homogenous entity and institutionalization the result of a collective choice.

This is particularly true of the political process school. As Michel Offerlé has underscored, activist collectives are invested by actors capable of making very differentiated use of them. Such collectives are "the result of the multiple random improvisations by which political entrepreneurs finding themselves there for no doubt very diverse reasons produce themselves as politicians while simultaneously producing the groups they bring together" (Offerlé, 2010, 40). The relationship between party and SMO is not a fixed given but rather closely depends on practical and symbolic confrontations within various arenas and the multiple social and activist stances taken by its players. As a result, one must enlarge one's field of vision and attend, not only to the "party tout court," but also to the interactions that the party, SMOs, and their players maintain, forge, activate, or reactivate with social movements, social organizations, trade unions, NGOs, and so on. It is therefore essential to combine an analysis at the micro-sociological level (individual involvement, local situational interactions, etc.) with a macro-sociological analysis at the scale of activist networks - that is, of the players engaged in the protest arena.

12 Some authors are more attentive to the play between parties and social movements, matters of "alliance, cooperation, competition, open conflict" (Luck and Deschezelles, 2011: 13). 
In order to do this, we must move beyond monographic works focused on a single party or movement. Instead, we must examine the flux of players at work in the protest arena over the medium and long-term and the dynamics of activist reconversions and multi-positioning. ${ }^{13}$ By multi-positioned players, I mean individuals who occupy leadership positions within one or more SMO organizations and simultaneously pursue a political career within a party. By activist reconversion, I am referring to the fact that former SMO leaders, at the moment of a party's creation or over the course of its existence, abandon their activism in an SMO to devote themselves to engagement within the party. These two phenomena will be grouped together under the term multi-engagement. Such an approach implies varying the levels of observation by analyzing the individual activism of players (Auyero, 2003), "microscopically" observing (Auyero et al., 2008) actors in context (at party and SMO meetings, protests, etc.) and understanding the collective dynamics that thus emerge at the scale of the protest arena.

The Latin American continent and, in particular, Mexico will serve as my terrain of investigation. The argument I develop nevertheless appears to be applicable to other configurations, particularly those marked by processes of political change, as in Arab countries. The nature of relations between parties and movements is always complicated. I now turn to an example drawn from field work conducted in Mexico: an analysis of the multi-engagement of leaders of the Party of the Democratic Revolution (PRD), a left-wing party created in 1989 in the context of a "democratic transition."

\section{Episodes of Protest and the Construction of Networks of Multi- Positioned Players}

On the basis of data collected by Joe Foweraker and Todd Landman for the period 1968-1990 (2000:12) and consultation of activist sources from the 1990s, five phases may be identified: a long phase starting in the early 1970 and ending in 1978, during which the main actors were peasants; a second phase between 1979 and 1984 focused on economic questions, during which the main players were trade unions and independent coordinating committees; the 1985-1986 phase concerning the housing question; that of 1988 on electoral issues; and, finally, a last phase centered on the Zapatistas

13 I prefer this term to doble militancia for, as we shall see, players are often engaged in multiple arenas. The latter is thus much too narrow. 
and the 1994 economic crisis. I have reconstructed the collective activist careers of the leaders of the PRD who held office during these phases in order to identify variations in themes and arena of engagement via statistical analysis and the reconstruction of individual career paths (Combes, 2011). ${ }^{14}$ In this part of the chapter, I will give attention to the effects of phases of mobilization on multi-engagement and thus on the players' arenas of engagement. By way of several examples, I will sketch the trajectory of the leaders who entered the PRD following a period of SMO activism.

\section{Guerillas and the Urban Popular Movement}

Like nearly everywhere else in the world, 1968 was a watershed year for Mexico. As the country prepared to host the Olympic Games, the student protest movement seemed a threat to the ruling party. On 2 October 1968, the army killed more than 200 students at Mexico City's Tlatelolco Square. Other student demonstrations were violently repressed in the early 1970 . In response to the fragmentation and atomization of the 1968 movement, guerilla groups flourished across the nation's territory (Okión Solano and García Ugarte, 2006) in rural communities and the outlying neighborhoods of the country's major cities (Eckstein, 1989; Haber, 2006; Tamayo, 1999; Bennett, 1998). More generally, activists who went into hiding worked with disadvantaged populations, offering literacy courses, free medical attention, assistance in land occupation, and help in formulating demands for basic services (water, electricity, sewer mains). These efforts helped establish a vast oppositional network. Gradually, guerilla operations gave way to efforts at aid and politicization. With the legalization of the left and the amnesty of the late 1970s, many groups chose to come out of hiding and sometimes joined the political game. These players thus switched arenas.

After the 1985 earthquake in Mexico, the process of "democratic transition" accelerated. Indeed, faced with the government's inability to assume its responsibilities in an emergency situation, requests by victims for immediate aid rapidly transformed into a vast protest movement. Some players, many of whom were drawn from the guerilla movement, mobilized the SMO networks they had forged during their years underground, becoming the main actors of what is known as the Urban Popular Movement (MUP).

14 In the first two chapters of my book, the effects of interactions with the various sectors of the state (various agencies and territorial levels) are procedurally analyzed for each of the period's movements. 
Thanks to them, this movement shifted from a focus on material demands to fighting the single-party state.

\section{Portrait 1}

As a student leader in the 1970s in northern Mexico, Marco Rascón ${ }^{15}$ became involved in the guerilla movement. He participated in multiple land occupations and was then imprisoned for having robbed a bank. After being freed, he left the north for Mexico City, where he contributed to the Point Critique review and began to work in the capital's working-class neighborhoods. After the 1985 earthquake, he created the Asamblea de Barrios (Neighborhood Assemblies) ${ }^{16}$ with other members of the review. This became the foremost organization of the Urban Popular Movement (MUP). Its spokesman, Superbarrio (Super Neighborhood), a masked wrestler (Cadena-Roa, 2002) for whom Rascón served as the intellectual inspiration, was the defender of the poor and democracy. He marched at the head of the massive protests organized in support of disaster victims, led meetings of Asamblea de Barrios and "confronted" the leaders of the PRI and the state itself in parody wrestling matches. And of course he always got the best of them! He even stated that he would be a candidate in the 1988 presidential elections but ceded his place to Cuauhtémoc Cárdenas. Rascón actively participated in the candidate's campaign. When the PRD was created, he was a member of the first national executive committee. While continuing to act as the leader of Asamblea de Barrios, he became president of Mexico City's PRD in 1991. In 1994, he was elected as a federal deputy and continued to use the art of parody as a political weapon in Congress. In 1997, he was named advisor to Cárdenas. After losing a 1999 primary bid in Mexico City to become party leader, he withdrew from the party's governing bodies.

\section{The 1986 Student Movement}

For the first time since the massacres of 1968 , students took to the streets in 1986 to demonstrate against government measures seeking to establish fees and entrance exams at Mexico City's National Autonomous University (UNAM), the breeding ground of politicians and elites since the 1910 Revolution. The University Students Council (CEU) was born. Broadly supported 
within UNAM by middle- and working-class students alike, the CEU did its part to further undermine the legitimacy of the PRI. When Cárdenas announced his candidacy in the 1988 election, the most prominent CEU leaders threw their support behind him and brought an army of activists with them.

\section{Portrait 2}

Marti Batres's engagement ${ }^{17}$ in the student movement coincided with his involvement in a MUP housing rights organization - the Popular Union of New Tenochtitlán (UPNT) - whose leader, René Berajano, was a trade unionist teacher. As the latter's heir apparent, Batres quickly became one of this influential organization's leading figures and created his own movement in the capital. Besides his activism in the domain of housing, he kept a foot in the student movement and became PRD president for Benito Juarez, Mexico City's most "middle class" district. He was elected as a local deputy in the aftermath of Cárdenas's victory in 1997. His "organization-movement" was the largest parliamentary group of the PRD, which itself held a large majority in the Legislative Assembly of the Federal District. Batres became its president at the age of 32 . Elected as a federal deputy, he became head of the PRD's parliamentary group three years later. In 2005, he was elected to the head of the PRD in Mexico City and, from 2006, was "secretary of social development," one of the most important "ministries" of the Government of the Federal District (GDF). In 2012, he left the PRD with a number of the historical leaders who had come from the social movements and followed López Obrador in the creation of a "party-movement," MORENA, which holds more oppositional positions than the PRD (Combes, 2012).

The tentative beginnings of the "democratic transition" in the late $1970 \mathrm{~s}$ and the politicization of social struggles in the 1980 s thus helped create favorable conditions for the partisan engagement of certain SMO players during the creation of the PRD, increasing the number of arenas in which they were active.

\section{Comings and Goings between Party and Movements}

As illustrated by the career of Gerardo Fernández Noroña, several movements that emerged after the creation of the PRD also gave rise to comings and goings between arenas. 


\section{Portrait 3}

Born in Mexico City in 196o, Gerardo Fernández Noroña ${ }^{18}$ defines himself as a "social and political leader driven by great passions and a controversial figure." ${ }^{19}$ A graduate in political sociology from the Metropolitan Autonomous University, he worked for several years at the Mexican Social Security Institute (1985-1992). In 1988, he was "noticed" (in his words) by the Mexican Socialist Party for his work at the head of a neighborhood SMO. Though he did not belong to the party, he became its candidate in his district's legislative elections. Gerardo joined the PRD upon its creation a year later. He rapidly climbed the rungs of the party's regional leadership and, in 1992, became president of the PRD for the State of Mexico. In 1994, though only 34 years old, he launched a primary campaign for the Senate, winning the internal party elections, which were challenged and then nullified. Gerardo persisted and became persona non grata in the PRD. A professional politician since 1992, he found himself without resources: he separated from his companion, herself a member of the PRD. The latter kept their beautiful apartment and gave him a taxi, which, according to him, became his only resource. Indebted, he found himself caught, like many Mexicans, in the spiral of increasing interest rates. Gerardo then decided to create his own organization for debtors' insurgency (Williams, 2001): the Citizen Assembly of Bank Debtors.

While the scale of his organization remained small, it quickly acquired some notoriety and benefited from large-scale media coverage thanks to the spectacular nature and varied repertory of the actions it carried out: activists intentionally throwing themselves under the wheels of the presidential car, festive happenings, theater plays based on the popular myths and rumors of the moment ${ }^{20}$ and so on. Gerardo Fernández Noroña adopted and transformed the heritage of the Urban Popular Movement (Haber, 2006). Starting in 1998, he also created a taxi union and, once again, organized a series of spectacular actions, including the total occupation of Mexico City's central square by taxis. On the strength of his success in organizing protest action, Gerardo Fernández Noroña once again set off to conquer the PRD. Thanks to the legitimacy he had re-acquired through his protest activity, Gerardo regained his place in the PRD. For several years, he occupied various posts of responsibility in party bodies before once again resigning from the party in December 2007 to become more fully involved 
in the "Popular Economy Defense Movement." In 2012, he, like Marti Batres, joined the López Obrador "party-movement" MORENA (Combes, 2012).

This example of an individual career shows that, in addition to multipositioning and the redeployment of social leaders within the party, players come and go between the PRD and SMOs. Yet, as we shall see later, these comings and goings are only viable to the degree that access to the party remains open. More generally, these trajectories also show that interactions between SMOs and parties depend on the conjunction of a multiplicity of factors: variables proper to the activist careers of actors (biographical considerations including private life, age or difficulties of the activist life, etc.) (Fillieule, 2001); global conjunctural variables, such as the emergence of a large-scale social movement or, as we have seen above, the reactions of particular state sectors at the local level as well as those of federal and national states; and, finally, considerations proper to particular domains (electoral, economic, social policies, etc.). The mobilization or reactivation of networks that we observe does not arise mechanically but depends on the convergence of these conjunctural factors. It is thus only by means of a precise analysis of the players' goals that one may understand their involvement in one or more arenas.

\section{The Networks of the "Partisan Milieu"}

What's more, the PRD leaders' involvement in multiple arenas of protest allows us to understand the formation of a "partisan milieu": that is, "the collection of consolidated relations between groups whose members' principal aim is not necessarily to participate in the construction of a party, though they in fact contribute to it by their activity" (Sawicki, 1997: 24).

The shift from social movement engagement to partisan engagement clearly does not result from the simple co-optation of players but rather from the completion of an activist phase that is reflected in the demobilization of the movement's members and, as a consequence, the "migration" of a generation of players toward a given arena or new structure (in this case, a party). Yet very often leaders or activists continue their campaigns, though less actively, in SMOs or at least maintain ties with these organizations. They are thus multi-engaged, as shown by the three portraits above of social movement leaders. In order to grasp this phenomenon, we must consider, not a given movement in isolation, but rather long-term episodes in order to understand the passage of entire generations of players from one arena to another. What remains to be understood is the manner in which 
the presence of social movement players affects a party: How did players coming from SMOs shape the organizations they captured or constructed?

Table 2.1 The Non-Partisan Engagements of National, Regional, and Local Leaders of the PRD between 1968 and $1997^{21}$

\begin{tabular}{|c|c|c|c|c|c|}
\hline & $\begin{array}{c}\text { phase } \\
1968-1977 \\
\text { (pop. = 93) }\end{array}$ & $\begin{array}{c}\text { phase } \\
\text { 1978-1984 } \\
\text { (pop. = 198) }\end{array}$ & $\begin{array}{c}\text { phase } \\
\text { 1985-1988 } \\
\text { (pop. = 293) }\end{array}$ & $\begin{array}{c}\text { phase } \\
\text { 1989-1993 } \\
\text { (pop. }=313 \text { ) }\end{array}$ & $\begin{array}{c}\text { phase } \\
\text { 1994-1997 } \\
\text { (pop. = 223) }\end{array}$ \\
\hline Student rights & $59 \%$ & $9 \%$ & $7 \%$ & $11 \%$ & $11.5 \%$ \\
\hline Peasant rights & $24 \%$ & $17 \%$ & $12 \%$ & $12 \%$ & $9.5 \%$ \\
\hline $\begin{array}{l}\text { Teacher trade } \\
\text { unionism }\end{array}$ & $8.5 \%$ & $15 \%$ & $9 \%$ & $8 \%$ & $9.5 \%$ \\
\hline $\begin{array}{l}\text { Private sector } \\
\text { trade unionism }\end{array}$ & $8.5 \%$ & $7.5 \%$ & $4 \%$ & $3 \%$ & $2.5 \%$ \\
\hline Housing rights & $9.5 \%$ & $14.5 \%$ & $16 \%$ & $21 \%$ & $27 \%$ \\
\hline Human rights & - & - & - & $6 \%$ & $4 \%$ \\
\hline $\begin{array}{l}\text { Gender } \\
\text { equality }\end{array}$ & - & - & - & $4 \%$ & $8.5 \%$ \\
\hline $\begin{array}{l}\text { Electoral fraud } \\
\text { reduction }\end{array}$ & - & - & - & $13 \%$ & $16 \%$ \\
\hline $\begin{array}{l}\text { Indigenous } \\
\text { rights }\end{array}$ & - & - & - & $5 \%$ & $14.5 \%$ \\
\hline Zapatism & - & - & - & - & $27 \%$ \\
\hline Others* & $38.5 \%$ & $28 \%$ & $26 \%$ & $28.5 \%$ & $4 \%$ \\
\hline None & $6.5 \%$ & $36.5 \%$ & $41.5 \%$ & $34 \%$ & $4 \%$ \\
\hline
\end{tabular}

Source: Database established on the basis of the CVs of primary candidates for parliamentary election (proportional) and a survey conducted at the April 2001 Congress of Zacatecas

\section{Partisan Arenas Shaped by SMO Players}

\section{The Supervision of Activists}

Depending on the circumstances, the activities promoted by SMOs take either an SMO or partisan form. While SMO activists do not directly participate in the activities of the party's local committees, their meetings are largely devoted to the activities of the PRD. The conduct of meetings of the Asamblea de Barrios (Marco Rascón's organization - Portrait 1) nicely

21 The analysis of activism has been carried out in terms of the five principal phases of mobilization identified for this period. 
illustrates the imbrication of the life of the movement with partisan life, as indicated by the following ethnographic description:

It is 4 p.m. on a Saturday in January. Many activists are unable to enter the conference room of the Asamblea de Barrios of the Romero Rubio neighborhood: the room is full, with around 200 people in attendance. Several families have come but most there are women accompanied by their children. The women are between 25 and 50 years old and talk in small groups. Very quickly, my presence draws attention and an official asks me to join her at a table at the back of the room facing the activists. The meeting begins. I am asked to say a few words to explain my presence to the activists. Then the heads of a series of committees give updates regarding their activities. There are as many committees as there are problems in the neighborhood and these are discussed one after the next: childcare in vacation periods, free access to eyeglasses for old people, gender relation workshops and of course issues of security. Once the committees have finished their reports, the follow up on housing requests is addressed. Several leaders detail the progress of case files, the activists concerned, meetings with creditors. Then nearly 45 minutes are devoted to PRD news: there is an update on its positions concerning political reform and important elections in several states of the federation, relations with the PAN are mentioned as well as the legislative agenda. Several words are then said concerning the municipal council of Mexico City, which was won by the PRD a year and a half earlier: the speaker focuses his intervention on "the media's campaign of harassment" against the Government of the Federal District (GDF - municipal council of Mexico City), calls upon the activists of Asamblea de Barrios to not let themselves be fooled and asks them to explain the real situation to their neighbors. Several minutes follow on the internal life of the party: the internal elections that will soon take place and the possibilities of alliance for Asamblea de Barrios. Finally, the activists are encouraged to participate in activities - participation in a demonstration, the dispatch of supplies - intended to support the Zapatistas (January 1999).

In the course of their internal meetings, social organizations thus see to tasks that traditionally fall to lower-level party committees. The PRD apparatus can thus carry out its more routine activities with a reduced number of officials and call upon PRD activists within the NSO - kept abreast of the party's agenda - when the need arises. As one leader remarked, "without strong participation in demonstrations [organized by the PRD] on the part of social organization activists, we would have been unable to maintain the 
pace of mobilization. ${ }^{\prime 22}$ As Russell Dalton and Martin Wattenberg (2002: 266) note, "the task of the party organization does not require that each member is heavily active and the activity of those who remain [active] has increased significantly. Political parties have clearly adapted to the greater volatility of their environment by enlarging their grassroots organizations, even if the foundations of their membership base have shrunk." The SMOs of the PRD's "partisan milieu" offer a flexible and "enlarged base." This mode of operation allows rapid adjustment to changing circumstances. For example, social organizations with leaders such as Marco Rascón, Marti Batres, or Genaro Fernández Noroña can rapidly mobilize hundreds of activists for demonstrations.

SMOs thus play a fundamental role in supervising the PRD's "base." This phenomenon can be observed in many Latin American countries. In its first years of existence, for example, Bolivia's MAS Party did not develop a party infrastructure and used associative and trade union premises for its activities (Do Alto and Stefanoni, 2006).

\section{Party Operation}

Does the activist origin of its members affect the internal organization of a political party? How does it influence party operation? As some authors have underscored, parties issued from social movements have often imported the latter's organizational models. European green parties, for example, have insisted on the place accorded their movement's heritage in internal party organization, with a strong emphasis on the forms of direct or "discursive" democracy present in the "new social movements" (Faucher, 1999: 215-242). Heavily influenced by the experience of these movements, they have also often developed a discourse concerning verticality, consensus, and the struggle against the leadership. And, as in the movements, the effort to put such principles into practice has obviously come up against many difficulties. Moreover, these parties place little emphasis on internal discipline - no doubt a reflection of the institution's relatively weak control over activists - and institutional loyalty is weak within them. Repeated (and often widely reported) episodes of internal conflict are the result. Does this hold for Mexico's PRD as well?

As was the case of European green parties, a discussion regarding democratic procedures took place within the PRD. In 1993, or four years after

22 Series of interviews with Agustín Guerrero, Secretary General of the PRD-DF, office of the PRD-DF, May 2000. 
the birth of the PRD, the party decided to adopt "open" internal elections to select candidates for elected office and party leaders at all levels (from municipal to national). All members of the PRD were allowed to participate in these elections, which took place, not in party premises, but rather in public spaces (squares, parks, on the street). While such an approach is today commonplace, this was not so in the 1990s (Pennings and Hazan, 2001). In 1996, this procedure was expanded to all Mexican citizens with voter identification, with participating voters automatically considered as affiliated with the PRD. In 1996, for example, 358,244 activists / voters participated in elections for the party's national leadership. In 1999, that figure had risen to 650,000 and, in 2002, 900,000 turned out to vote. In the debates that accompanied the implementation of these elections, multi-positioned players such as Marco Rascón, Marti Batres, and Genaro Fernández Noroña seem to have played a decisive role in the choice of this mode of operation. This is shown by the archives of the party governing bodies (national council, national executive committee) and the texts of the congress that approved these reforms. My attention was focused on the then emerging party norm (and so as much on the debates, negotiations, adjustments between players as on the texts that were finally adopted). These players perceived internal elections as a way of maintaining the ties between the PRD and the SMOs of the party milieu. Indeed, the internal operation of the SMOs allowed them to mobilize resources that could be reinvested in the internal workings of the party. Most SMOs have ways to strongly inspire voting by their members. For example, SMOs that receive state credits for the construction of social housing (Haber, 2006) use a points system to establish an order of priority for access to these highly coveted resources, with points attributed on the basis of member participation in party events, such as protests, meetings, and some of the PRD's internal elections, as I observed by following the SMO activities of Marco Rascón (Portrait 1) and Marti Batres (Portrait 2). I cannot here enter into the complex debate over clientelism, which I have addressed elsewhere (Combes and Bey, 2010). Very schematically, it can be said that I share Javier Auyero and Pablo Lapegna's concern to avoid contrasting clientelism with collective action (Auyero et al., 2009), as is often the case in the literature. Going beyond Javier Auyero's position (Auyero, 2000), which in particular analyzes clientelism in terms of symbolic domination, I subscribe to the position staked out by Julieta Quirós in her excellent book El porque de los que van (2011), which calls for "an anthropology of politics as it is experienced."

This mode of selection favored multi-positioned players in the competition to become a candidate for elected office: faced with the leader of a housing 
rights association such as Marti Batres (Portrait 2), who enjoys a strong foothold in his district and is capable of mobilizing association activists, even a nationally recognized intellectual who played a fundamental role in the debate over democratization has no chance of winning an internal election. In 1997, for example, 90 percent of the PRD's local Mexico City deputies came from SMOs. The significant place occupied by Marti Batres's SMO and its status as a powerful current in the party partly explains how the latter became president of Mexico City's local legislature when only 32 years old. These players, however, do not have the same social and gender profiles as other PRD leaders: most have a working-class background (sons of workers or peasants) and have very often benefited from significant social promotion thanks to the expansion of university access in the 1960 s and $70{ }^{23}$ Women also generally became involved in activism by way of SMOs (particularly those associated with the urban movement), which explains the relatively important representation of women in the PRD compared to other parties.

\section{Transferring Resources and Know-How}

Internal struggles over party construction can sometimes advantage the resources and activist know-how specific to SMOs over more traditional party resources (legislative knowledge, negotiation experience, national and sometimes international standing in the fields of politics and the media, bureaucratic competence, and so on). The leaders' origin in protest movements explains their recourse to a repertory originating in the social movement tradition. Paul Almeida presents this as one of the criteria of partyism: the use of social movement-type strategies (e.g., disruptive actions and street demonstrations) to mobilize party members and other groups to achieve social movement goals $(2010,174)$.

In the Mexican case, the SMOs' presence in working-class neighborhoods, strong capacity for mobilizing activists and sympathizers, and experience organizing protests (demonstrations, various forms of resisting the "repression" of local authorities, etc.) all contribute to the influence they enjoy within parties in these struggles. In the hands of leaders who are less well-equipped in social and academic terms, however, these resources are the object of a permanent campaign of delegitimization, with political opponents accusing them of incompetence and, above all, clientelism. Many SMO leaders who enter the political arena experience this form

23 I devote a chapter of my work to the specific question of social capital by activist origin (Combes, 2011: ch. 5). 
of delegitimization. As in the Mexican case, they generally come from a working-class background, unlike other politicians. As an example, one may here cite the leaders of Bolivia's MAS Party. After becoming deputies, they were criticized as incompetent due to their low level of educational attainment and their failure to master the Spanish language. Yet despite this stigmatization, a new political generation issued from SMOs sometimes succeeds in asserting itself in the political arena.

Table 2.2 Arenas and the Resource Transfers of Multi-Positioned Players

\begin{tabular}{ll}
\hline Arena & Type of Exchange \\
\hline From social movement to party & Activists \\
& Protest experiences \\
& Territorial presence \\
From party to movement & Material resources \\
& Advice \\
& Jobs \\
& Symbolic remuneration \\
& Material resources \\
\hline
\end{tabular}

This table summarizes the various exchanges that can take place between parties and social movements by way of multi-positioned leaders. These exchanges are generally local, one-off and strongly depend on the fluctuating ties between collective players and individuals and sometimes even interpersonal relations. These ties also show significant variation over time. For example, during periods of electoral victory, parties distribute jobs and resources (material, pamphlets, posters, etc.) sporadically or en masse to multi-positioned players. In periods of electoral retreat, the latter can once again become paid SMO employees. Every evolution of the context entails a repositioning of players within the various arena and sometimes renegotiation of the terms of the relationship.

Yet, it should be specified that, in order to understand the implantation of social movement leaders in the party, I have chosen to take an approach that differs from the social movement institutionalization one. In this sense, my analysis allows us to move beyond certain limits inherent to the analysis of social movement institutionalization by showing how activists, despite (or because of) the institutionalization of their movement, experience very diverse trajectories ${ }^{24}$ : some become involved in another movement; others 
become party or administrative personnel; for yet others, a more or less extended period in formal politics is at some point followed by renewed involvement in protest. By shifting our focus from the movement to activists and by placing their activism in a long-term context - that of an entire career of activism rather than solely the period of participation in a single movement - the institutionalization of a mobilization no longer appears as the end of activism but instead as a transformation of involvement opening the way to a wide variety of individual trajectories.

\section{By Way of Conclusion: Conceiving Multi-Engagement in Terms of Cycles}

To emphasize interactions between SMOs and parties and insist on the importance of multi-positioned actors is to swim, in part, against the current. At a time when some authors see a disconnect between political parties and "civil society" (Katz and Mair, 1994; 1995), it is tempting to study parties independently of their social and activist environments. The issue at stake is thus to conceive of the party-movement relationship in its full continuum. This can be done by bringing the contributions of two particular approaches to bear on the question: what are known as the contentious politics approach and the societal approach to political parties. These are attentive to the social and activist characteristics of the players and their interactions on the ground.

We must also break with the approach that consists of focusing on organizations (whether social movement or party) in order to attend to the long-term trajectories of multi-positioned players. The value of doing so is only revealed once we have moved beyond monographic studies on a given movement or party taken in isolation and revealed the dynamics at work in the political and protest arenas and the complex multiplicity of exchanges that take place there according to the various episodes of protest and arenas (political, protest, local, national, etc.).

Multi-engagement develops through episodes of protest, interaction with certain state sectors and the political reconfiguration of relations between institutional spheres and protest spaces. In order to achieve a global understanding of these phenomena, we must not stop at some arbitrary moment or in the midst of a sequence of mobilization. Rather, we must focus on "long" periods corresponding, at the very least, to the duration of an activist career. Such an approach profits from being combined with an ethnographic analysis of engagement, that is, the observation of players 
on the ground in order to understand how their games and experiences (Quirós, 2011) vary according to the places in which they find themselves, their emotions, and the actors with whom they interact.

\section{References}

Almeida, Paul D. 2010. “Social Movement Partyism: Collective Action and Political Parties."in Nella Van Dyke and Holly McCammon, eds. Strategic Alliances: New Studies of Social Movement Coalitions. Minneapolis: University of Minnesota Press.

Alvarez, Sonia, and Arturo Escobar, eds. 1992. The Making of Social Movements in Latin America. Boulder: Westview Press.

Alvarez, Sonia, Evelina Dagnino, and Arturo Escobar, eds. 1998. Cultures of Politics/Politics of Cultures: Re-Visioning Latin American Social Movements. Boulder: Westview Press.

Auyero, Javier. 200o. Poor People's Politics. Durham, NC: Duke University Press.

- 2003. Contentious Lives: Two Women, Two Protests, and the Quest for Recognition. Durham, NC: Duke University Press.

Auyero, Javier, Fernanda Page, and Pablo Lapegna. 2009. "Patronage Politics and Contentious Collective Action: A Recursive Relationship." Latin American Politics and Society 51: 1-31.

Bennett, Vivienne. 1998. "La Evolución de los Movimientos Urbanos Populares en México entre 1968 y 1988.” América Latina Hoy 7: 89-96.

Cadena-Roa, Jorge. 2002. "Strategic Framing, Emotions, and Superbarrio: Mexico. City's Masked Crusader." Mobilization 7: 201-216.

Calderón, Fernando. 1995. Movimientos sociales y política. Mexico: Siglo XXI/Unam.

Combes, Hélène. 2011. Faire Parti. Trajectoires de gauche au Mexique, Paris, Karthala.

- 2012. Quand la Gauche Mexicaine Gouverne... Sans Gouverner. L'Expérience du 'Gouvernement Légitime’” in Olivier Dabène ed., La Gauche en Amérique Latine, 1998-2012. Paris: Presses de Sciences-Po.

Combes, Hélène, and Marguerite Bey, eds. 2011. El clientelismo a debate. Special issue of Desacatos 36.

Dalton Russell, and Martin Wattenberg, eds. 2002. Parties without Partisans. Oxford: Oxford University Press.

Do Alto Hervé, and Pablo Stefanoni. 2006. Evo Morales de la Coca al Palacio. Una Oportunidad para la Izquierda Indígena. La Paz: Malatesta.

Eckstein, Susan. 1989. "Poor People versus the State and Capital: Anatomy of a Successful Community Mobilization for Housing in Mexico City.” In Susan Eckstein, ed., The Power and Popular Protest: Latin American Social Movements. Berkeley: University of California Press.

Faucher, Florence. 1999. Les habits verts de la politique. Paris: Presses de Sciences Po.

Fillieule, Olivier. 2001. "Propositions pour une Analyse Processuelle de l'Engagement Individuel." Revue Française de Science Politique 51: 199-215.

Foweraker, Joe, and Todd Landman. 2000. Citizenship Rights and Social Movements. Oxford: Oxford University Press.

Goldstone Jack, ed. 2003. States, Parties and Social Movements. Cambridge: Cambridge University Press.

Goodwin Jeff, and James M. Jasper. 1999. "Caught in a Winding, Snarling Vine: The Structural Bias of Political Process Theory," Sociological Forum 14: 27-54. 
Gunter, Richard, and José Ramón Montero. 2002. "Introduction: Reviewing and the Reassessing Parties." In Gunter Richard, José Ramón Montero, and Juan J. Linz, eds., Political Parties: Old Concepts and New Challenges. Oxford: Oxford University Press.

Haber, Paul Lawrence. 2006. Power from Experience, University Park: Pennsylvania State University Press.

Hipsher, Patricia. 1998. "Democratic Transitions as Protest Cycles: Social Movement Dynamics in Democratizing Latin America.” In David Meyer, and Sidney Tarrow, eds., The Social Movement Society. Lanham, MD: Rowman and Littlefield.

Joseph Lauren, Matthew Mahler and Javier Auyero eds. 2008. New Perspectives in Political Ethnography. New York: Springer.

Katz, Richard, and Peter Mair, eds. 1994. How Parties Organize. London: Sage.

- 1995. "Changing Models of Party Organization and Party Democracy: The Emergence of the Cartel Party." Party Politics 1: 5-28

Keck, Margaret. 1992. The Workers' Party and Democratization in Brazil. New Haven: Yale University Press.

Kitschelt, Herbert. 1989. The Logics of Party Formation: Ecological Politics in Belgium and West Germany. Ithaca, NY: Cornell University Press.

Kriesi, Hans Peter, Ruud Koopmans, Jan Willem Duyvendak, and Marco Giugni. 1995. New Social Movements in Western Europe. London: UCL Press.

Levitsky, Steven. 2003. Transforming Labor-Based Parties in Latin America: Argentine Peronism in Comparative Perspective. New York: Cambridge University Press.

Levitsky, Steven, and Kenneth Roberts. 2011. The Resurgence of the Latin American Left. Baltimore: Johns Hopkins University Press.

Luck, Simon, and Stéphanie Dechezelles. 2011. La voix de la rue, la voix des urnes. Partis et mouvements sociaux. Rennes: Presses Universitaires de Rennes.

Macías, Carlos. 2012. "De las Rutas a las Urnas. Intercambios y Lealtades en el Movimiento Campesino Paraguayo." Cahiers des Amériques Latines 69: 81-102.

McAdam, Doug. 1988. Freedom Summer. New York and Oxford: Oxford University Press.

McAdam, Doug, and Sidney Tarrow. 2010. "Ballots and Barricades: On the Reciprocal Relationship between Elections and Social Movements." Perspectives on Politics 8: 529-542.

Meyer, David. 2007. The Politics of Protest. New York: Oxford University Press.

Offerlé, Michel. 2010. Les Partis politiques. $7^{\text {th }}$ ed. Paris: Presses Universitaires de France.

Okión Solano, Verónica, and Marta García Ugarte, eds. 2006. Movimientos armados en México, siglo XX. México: El Colegio de Michoacán/CIESAS.

Panebianco, Angelo. 1988. Political Parties: Organization and Power. Cambridge: Cambridge University Press.

Petras, James, and Henry Veltmeyer. 2011. Social Movements in Latin America. New York: Palgrave.

Pennings, Paul, and Reuven Hazan. 2001. "Democratizing Candidate Selection: Causes and Consequences." Party Politics 7: 267-275.

Piven, Frances Fox, and Richard Cloward. 1977. Poor People's Movements: Why They Succeed, How They Fail. New York: Vintage Books.

Quirós, Julieta. 2011. El Porque de los Que Van. Buenos Aires: Editorial Antropofagia.

Randall, Vicky, and Lars Svåsand. 2002. "Party Institutionalization in New Democracy." Party Politics 8: 5-29.

Rocha, Daniella. 2011. "Des Réseaux Protestataires au Milieu Partisan. Socio-histoire de la Genèse du Parti des Travailleurs à Brasilia (1978-1980)." In Simon Luck and Stéphanie Dechezelles, eds., La Voix de la Rue, la Voix des Urnes. Partis et Mouvements Sociaux. Rennes: Presses Universitaires de Rennes. 
Sánchez, Estévez Reyna. 2004. Los Símbolos en los Movimientos Sociales. El Caso de Superbarrio. México: UAM-X.

Sawicki, Frédéric. 1997. Les Réseaux du Parti Socialiste. Sociologie d'un Milieu Partisan. Paris: Belin.

Sawicki, Frédéric, and Johanna Siméant. 2010. "Decompartmentalizing the Sociology of Activism:

A Critique of Recent Tendencies in French Studies." Sociologie du Travail 52: 83-109.

Suh, Doowon. 2011. "Institutionalizing Social Movements: The Dual Strategy of the Korean Women's Movement." The Sociological Quarterly 52: 442-471.

Tamayo, Sergio. 1999. Los Veinte Octubres Mexicanos. Ciudadanía e Identidad Colectivas. Mexico:

Universidad Autónoma Metropolitana.

Tarrow, Sidney. 1994. Power in Movement. Cambridge: Cambridge University Press.

Van Cott, Donna Lee. 2005. From Movements to Parties in Latin America: The Evolution of Ethnic Politics. Cambridge: Cambridge University Press.

Williams, Heather. 2001. Social Movements and Economic Transition: Markets and Distributive Conflict in Mexico. Cambridge: Cambridge University Press. 


\title{
$3 \quad$ Political Parties and Legislators
}

\author{
An American Perspective \\ Katherine Krimmel
}

"I have a vision and you are a part of it." On 18 May 1992 at the Palace Theatre in Los Angeles, then-Governor Bill Clinton memorialized an enormous success for the Lesbian, Gay, Bisexual and Transgender (LGBT) movement. Clinton was the first presidential candidate ever to openly support the LGBT community and actively seek their votes, and his campaign marked the beginning of what has become a high-profile alliance between the LGBT movement and the Democratic Party. In exchange for this historic support, LGBT voters donated almost \$4 million to Clinton's 1992 campaign and favored him 80 percent to 20 percent on election day. Within a year, however, the vision appeared to fade, as Clinton receded from his campaign promise to issue an executive order lifting the ban on military service for LGBT individuals. His “Don't Ask, Don't Tell, Don't Pursue" proposal, offered as a "compromise" between the LGBT movement and its opponents, was lambasted by movement leaders, journalists, and grassroots activists who expected more from their White House ally. Torrie Osborn, Executive Director of the National Gay and Lesbian Task Force, characterized the alleged compromise as a "repackaging of discrimination," and Tim McFeeley of the Human Rights Campaign Fund publicly lamented the "shattering disappointment for millions of gay, lesbian and bisexual Americans" (Rimmerman, 1996: 119; Los Angeles Times, 1993).

From one angle, this story is banal - a presidential candidate winks and smiles to gain support, and then fails to honor a campaign promise once in office. From another angle, though, it raises important questions about the relationship between political parties and social movements. Social movement scholars often explain policy outcomes with reference to "elite allies." That is, movements are more likely to succeed when they have allies in powerful positions. According to the strong version of this argument, elite allies are necessary for movements to achieve policy change. According to weaker versions, elite allies merely increase the possibility of policy change (Soule and King, 2006: 1882). This intuition makes sense - movements should be more likely to achieve their policy goals when they have friends in high places. But, how do they acquire such allies? If we think about social 
movements as political outsiders attempting to influence political insiders, then an elite ally is as much a consequence as a cause of movement success.

To understand how and why movements might develop elite allies, we must examine lawmakers' goals and strategies. What do they want, and how might movements appeal to them? A simple and pessimistic answer to this question would be that politicians care primarily about raising money for their campaigns. This would not be good news for most social movements, which generally cannot compete financially with other special interest groups. But money is not the only thing that matters. Movements can appeal to lawmakers directly by offering other resources, like information and assistance with electoral mobilization, and indirectly by influencing their constituents' views on issues. These kinds of actions can heighten lawmakers' incentives to become movement allies.

Forging relationships is not the end of the story, since elite allies are not guaranteed to support any particular bill. As the LGBT case demonstrates, the relationship between movements and their "allies" can be complicated. In popular and scholarly discourse, social movement battles are often depicted as fights between movements and countermovements (e.g., prolife versus pro-choice, gun rights versus gun control, etc.). I argue that these conflicts, while certainly not meaningless, are often secondary to the battles between movements and their own allies. This is true even if the movement has "picked sides" in party politics, giving them a more politically homogenous coalition of allies. From a policy perspective, the position of a movement in relation to its party and other movements within the same partisan camp matters at least as much as its position vis-à-vis its opposition. Even the most liberal government can only produce so much liberal policy. It would be very difficult, for example, for the Democratic Party in the United States to enact pro-environment, pro-women's rights, pro-worker's rights, and pro-LGBT rights laws in one presidential term, let alone one session of Congress. Gathering support for any one bill requires lawmakers to spend political capital. Each progressive policy also makes the government appear more liberal in the eyes of voters. To avoid running out of capital and moving too far from the median voter, even a Democratic Party highly committed to all of its progressive allies' causes will need to pick and choose which issues to prioritize.

Hence, it is not especially surprising that movements' ability to negotiate with their allies seems to vary over time. Most if not all social movements experience ups and downs in their relationships with elected officials, even those with whom they have relatively strong alliances. Once a movement acquires an ally, it faces the separate task of getting its ally to act on its behalf. 
This challenge has an additional dimension in a collective decision-making body, like a legislature. If the movement's ally is an individual or small group of legislators, then she (or they) face the additional task of persuading her (or their) colleagues to support the cause. This helps to explain why social movements often do not get what they want, even during the seemingly auspicious periods when their ally party controls the government.

To better understand these dynamics, I will discuss parties and legislatures as sites of political decision making. What kinds of arenas are they? How do their rules and norms empower and constrain their own members, as well as their movement allies? Addressing these questions will provide a sense of the opportunities and challenges facing movements with legislative goals. This analysis is based primarily on observations about American parties and the United States Congress, a bicameral legislature in a twoparty system with single-member districts and winner-take-all elections. Some of the dynamics described herein may be different for systems with other characteristics. Nevertheless, this can serve as a starting point for thinking about the kinds of dilemmas social movements may face in their interactions with parties and lawmakers.

\section{Parties (and Movements) in Government, as Organizations, and in the Electorate}

Key (1964) argues that parties are not single entities. In other words, there is not simply one arena called "the party." Rather, there is the party in government, the party as organization, and the party in the electorate. When people claim parties have become weak in the United States, they are often referring to parties in the electorate. More people identify as independents today than earlier in American history. When people claim parties are too strong in the United States, they are often referring to parties in government, as party line voting has reached historic levels. Aldrich (1995) reinforces the utility of this tripartite framework in his highly influential book, Why Parties?, though he prefers a third category of parties in elections to parties in the electorate. Either way, parties are better understood by distinguishing the arenas in which they operate. Each has its own set of norms, routines, and players.

The same is true for social movements. Just as Key and Aldrich note that parties are complex organizations that cannot be understood fully on one plane, so are movements. Indeed, I have argued that we can use the same tripartite framework commonly used to study parties to analyze social 
movements and other special interest groups (Krimmel 2013). Like parties, many movements want to appeal to some portion of the electorate for support. This aid could be financial (e.g., donating money to the organization) or non-financial (e.g., joining a protest or becoming a member). If we wanted to measure movement strength in the electorate, we could look to see what percentage of the electorate belongs to the movement or has ever participated in one of the movement's efforts. At the broadest level, we could even use survey data to see how many people sympathize with the movement's positions. To measure social movement strength in government, we could consider how many movement actors occupy positions of power, or how often movement leaders are invited to decision-making tables in the legislative or executive branches. From another angle, we could also consider the extent to which government officials support the movement's goals. To measure organizational strength, we could look at the movement's financial resources, as well as its level of professionalization (e.g., staff size, number of offices, etc.).

Just as with parties, we may get very different pictures of movement strength in these three arenas. The challenges that movements face in each of these arenas will also differ. To fully understand movements' relationships to parties, it would be valuable to analyze their interaction within and between all three spheres. They may have overlapping goals and/or resources in one or more spheres. For example, both may want to convince the electorate of a certain policy position, or figure out how to reach a particular group of voters, or tackle a specific policy problem. The size of the overlap between parties and groups will vary across groups, over time, and between arenas.

This piece will focus primarily on parties in government, and even more specifically on parties in the legislature. To understand movements' interactions with parties in this arena, we need to consider lawmakers' goals, the strategies they typically employ, and the means available to them in these pursuits.

\section{Legislators' Goals, Strategies, and Means}

We can begin with the obvious but still critical observation that politicians care very much about winning elections. David Mayhew's classic 1974 book, Congress: The Electoral Connection, starts with the assumption that Congressmen are motivated solely by re-election. While this may be an exaggeration, it turns out to be a useful one. For, even if politicians 
have other aims, like the enactment of particular policies, electoral success is a proximate goal. Aldrich seconds the importance of this observation, claiming that we must understand the re-election goals of party members in order to understand their behavior.

Despite the unquestionable importance of elections, other goals deserve some attention as well. Key, among others, notes that while re-election may be parties' main concern, they often have policy goals as well (Key, 1942: 244). Policy interests may stem from personal or constituent policy preferences, or both. Member of Congress also care about reputations - both their own, and their institution's. Mayhew (1974) argues that members of Congress value the legislative branch's status and work to protect it (though not always successfully, as deteriorating public approval of Congress indicates). One might also hope that officeholders care about effective governance. Here, however, I will focus on electioneering and policy making because they are the two most widely accepted goals in the American Congress literature. Moreover, pursuing the goals of reputation maintenance and good governance would require many of the same strategies and resources as the goals of re-election and policy making.

Members of Congress tend to employ three strategies to achieve their goals: advertising, position-taking, and credit-claiming (Mayhew 1974). Advertising is meant to increase name recognition and build a positive image for a candidate. These kinds of efforts are very general, and do not involve substance (i.e., issues). Examples include appearing on television, shaking hands with constituents outside grocery stores, and attending community parades and other events. These types of activities get (or keep) the candidate on people's radar, and can make them more likely to support her on election day.

More substantive efforts fall into the second and third categories of position-taking and credit-claiming. As its name indicates, position-taking involves public statements on issues. These can be rhetorical (e.g., giving a speech at a town hall meeting, debating an issue on the floor of Congress, etc.) or behavioral (e.g., casting a roll-call vote in support of the issue). While these strategies may seem obvious, they are not costless. Indeed, researching what issues their constituents want them to address in speeches and what positions they should take on roll-call votes can require a great deal of time and resources (Krehbiel, 1991).

Credit-claiming, as its name suggests, involves taking credit for "particularized benefits" secured for constituents (Mayhew, 1974). This requires many of the same resources as position-taking, since members of Congress will need to know what their constituents want. However, it also requires a certain 
degree of successful action beyond simply casting a roll-call vote. They might need to add something to the budget or pass a piece of legislation. This requires skills in coalition-building and navigating Congress's labyrinthine rules, norms, and routines. Building coalitions on controversial issues may require particularly intense persuasion. In this pursuit, it can be valuable for members of Congress to have incentives (e.g., campaign donations, endorsements, and so on) to offer their colleagues in exchange for their support.

Coalition-building is also important outside the halls of Congress. To win elections, lawmakers need to undertake the additional strategy of mobilization. Of course, the three strategies outlined above (advertising, positiontaking, and credit-claiming) may indirectly contribute to electioneering efforts; however, candidates still need to intensify their direct mobilization activities leading up to an election. Approval is worthless if the candidate's constituents do not go to the polls. Campaigning requires money, volunteers, and communication networks to promote the candidate and get out the vote.

Social movements can appeal to parties' electoral interests by helping them carry out these strategies. Mass-based membership organizations should be especially adept at mobilization. They can also aid parties by gathering information about their members and helping parties understand how to appeal to them. These are significant non-monetary resources that groups can offer parties. Of course, it is important to keep in mind that their value may vary over time as electoral contexts change. They are likely to be especially precious when elections are very competitive. This helps to explain how movements might acquire elite allies, especially those who are not ideologically predisposed to support the movement's cause.

The need for movement resources may vary across countries and over time. Highly professionalized legislatures, like the United States Congress, can gather more of their own information than less professionalized legislatures, for example. When they are more self-sufficient, their need for assistance from social movements may be reduced. There are many ways to evaluate professionalization. One key measure is staff size. A large staff can assist a legislator in reading bills and researching their potential consequences for constituents. Two other important measures of professionalization are compensation and number of days in session. These are often related. Today, salaries are high enough that legislators in many nations (and even subnational units) can devote themselves full-time to their positions. If compensation is meager, however, lawmakers may maintain others jobs in the public or private sector during their terms. Historically, this was often the case for American state legislators. Part-time legislators may need to rely more on informational shortcuts and outside assistance, 
which may provide opportunities for movements to build relationships with them. Legislatures whose members are part-time may also meet for shorter sessions than legislatures comprised of full-time members. With more intense time constraints, part-time legislators may be more likely to turn to social movements and others outside the state for assistance.

Providing resources that could assist lawmakers with the tasks of advertising, position-taking, credit-claiming, and mobilizing voters can help movements acquire and maintain allies in the legislature. The next important question is, if lawmakers are willing to support a social movement's goals, what means do they have to do so? There are many options available to lawmakers, and they require different levels of commitment. At the simplest level, they could vote in favor of a movement's bill (or against a bill the movement opposes, depending on the situation). This does not require much effort, though it could be used against the lawmaker in a campaign. That someone caters to "special interests" is a common charge raised against incumbents by electoral challengers. Lawmakers could also introduce a bill on behalf of a movement. This requires a greater commitment, since it more closely identifies the lawmaker with the movement's goals, and also involves some work in drafting or at least reviewing the movement's bill. As discussed below, however, introducing a bill is only the first step in a long policy process. Most bills introduced in Congress never even reach a vote, let alone pass. The third and arguably strongest means at a lawmaker's disposal is his power to persuade his colleagues to support the movement's bill. He might offer his support for another bill of interest to his colleagues in exchange for their support on the movement's bill. In lieu of, or in addition to, support on another bill, the lawmaker could also offer campaign assistance. If she is a well-known, senior member of Congress, she could offer to endorse a lesser-known member or provide fundraising assistance. She might also deliver a speech on the floor of Congress to persuade others to support the movement's bill. These actions require more investment from lawmakers, so they are likely to be employed only by strongly committed allies.

\section{Challenges to Movements' Success in the Legislative Arena}

Even the most dedicated allies encounter major hurdles in achieving legislative goals, however. I will review some of the most significant constraints faced by parties and legislators, which can turn into challenges for social movements as well. The first is related to time, which is always scarce in a 
busy legislature like the United States Congress. Members, and the issues for which they advocate, must compete with one another for access to the agenda. Other limitations stem from hierarchy. That is, newer members of Congress typically have less power than more senior members of Congress. Still other limitations are inherent to deliberative bodies like legislatures. Unlike in the executive branch, where the president can make many decisions unilaterally, legislatures engage in collective decision making. Policy success requires considerable coordination and cooperation, and there are many opportunities for obstruction. An important factor influencing social movements' legislative success will be the number and nature of veto players in the system. This can vary from legislature to legislature. Even if a majority of lawmakers support a social movement's goal (or any bill, for that matter), a small minority of their colleagues - or, in some cases, even a single member - may be able to obstruct efforts to achieve that goal. Navigating these different constraints can be frustrating, since the best strategy for overcoming one of them may not work well for another. This tension can create dilemmas for social movements.

We can begin with time constraints. Collecting "yays" and "nays" is not the biggest challenge facing social movements in a busy legislature. Rather, the most formidable hurdle for most bills involves getting through House committees to reach a vote in the first place. After someone introduces a bill in the House of Representatives, the Speaker directs it to one of the chamber's many committees for review. To receive consideration from the full body, the bill must be reported back to the floor from its assigned committee. An overwhelming majority of bills never reach this stage. With many bills to consider, committees cannot even hold hearings on all of them, let alone revise or vote to send them all to the floor. Of the 2,967 bills introduced in the House of Representatives in 2012, for example, only 335 were reported from committees to the floor (US Senate, 2013). Thus, movements face powerful gatekeepers at this stage of the legislative process. Committees' ability to stymie progress gives them leverage in negotiations over bills' substance as well.

Committee leadership was a key factor leading to what Katznelson has called the Southern "structural veto" in Congress, which frustrated gains for labor and civil rights activists in the early to mid-twentieth century (Katznelson, 2005; Farhang and Katznelson, 2005). Because one-party rule and disenfranchisement of African-Americans led to non-competitive elections in the South, members of Congress from this region had longer tenures than their non-Southern brethren, who faced more competitive elections. Because seniority is a key factor influencing the selection of 
committee leaders, Southern legislators controlled a significant percentage of the committee system before the civil rights revolution and Republican realignment of the region. This gave Southerners power to shape as well as obstruct the progression of legislation. Though Southern Democrats agreed to support some labor legislation, they would not approve anything that could threaten the region's racial hierarchy. Farhang and Katznelson note, "In light of their racialized, low-wage, mostly agrarian political economy, they insisted on occupational exclusions, leaving agricultural and domestic labor, the most widespread black categories of employment, outside the ken of legislative protection and empowerment" (Farhang and Katznelson, 2005: 6-7). Powerful committee leadership both slowed the enactment of progressive legislation, and also limited its breadth.

As the nation has become larger and more complex, legislative workload has increased, and competition for agenda space has become even more fierce. Figure 3.1 uses data from Adler and Wilkerson's Congressional Bills Project to show the percentage of bills introduced in each year from 1947 to 2002 that get reported out of committee, and, secondarily, the percentage that pass. ${ }^{1}$ It is fairly clear from this graph that reaching the floor is the primary challenge in contemporary American politics; the gap between bills introduced and reported is much larger than the gap between bills reported and passed. The challenge has intensified over time, as the percentage of bills reported from committee fell from a little under 20 percent in the late 1940 s to roughly 8 to 12 percent in the late 1990s and early 2000s. Of course, the perceived chance of passage may influence the decision to release a bill from committee. Nevertheless, getting on the agenda appears to be the foremost challenge; once a bill reaches a vote, it has a good chance of passing the House.

The question, then, is how movements can motivate legislators to prioritize their issues. In the United States House of Representatives and other legislative chambers with strong committee systems, having allies on key committees of interest to the movement is very important. A majority of the House might support a particular farm bill, for example; but, the committee to which the bill was sent could prevent them from expressing their support by refusing to release the bill from committee. A farming movement pushing this bill would benefit greatly from having allies on the House Committee on Agriculture, the most likely destination for this kind of bill.

1 Occasionally, an unusually high number of bills will not be assigned to a committee. In these years, the percentage of bills passed may exceed the percentage reported from committee. 
Figure 3.1 Percentage of Bills Introduced in the US House Reported from Committee and Passed

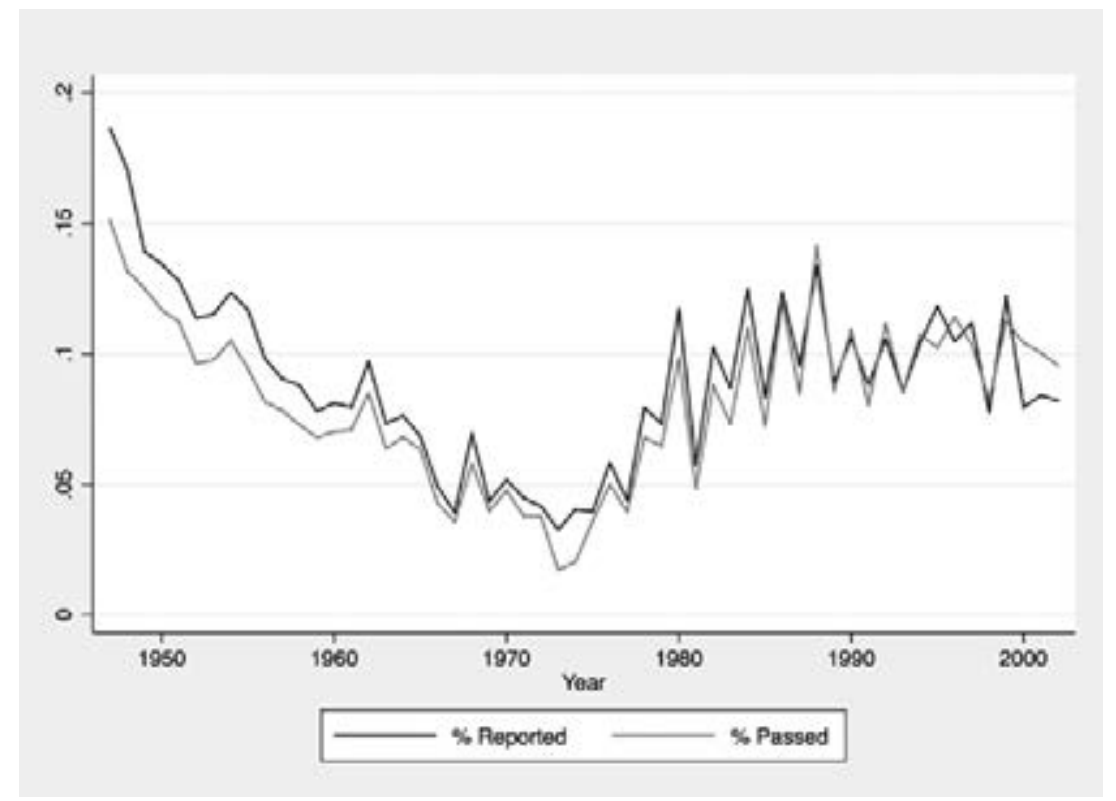

However, allies' value may change when party control of Congress changes. This is part of the dilemma of party alliance. Reaching the floor can be very difficult for members of the minority party in the House of Representatives because majority party leaders can use committees to monopolize the agenda. Cox and McCubbins argue in their highly influential 2005 book, Setting the Agenda, that the majority party is like a "cartel" with significant control over the House agenda and, by extension, legislative politics generally. To illustrate their theory, Cox and McCubbins develop the "roll rate." A party gets "rolled" if a majority of its members vote against a bill, and it passes anyway. They find that the majority party almost never gets rolled, the minority party gets rolled much more frequently, and most bills that reach the agenda propose to move policy toward the majority's ideal point.

This has a few implications for social movements, which may pull in different directions. First, it suggests that movements will need support from members of the majority party on key committees to reach a vote. Thus, it might be wise for movements to focus their efforts on a few individuals on these committees. However, this strategy could lead to problems in 
other ways. It is, essentially, committees' job to assure that bills that could potentially roll the majority party do not reach the floor. To receive support from members of the majority party on key committees, then, movements will need broader support from the majority party. This tension could strain a movement with limited resources. Gathering this kind of support in one party would be difficult; building it in two might be impossible for many movements. Even if they could appeal ideologically to both parties, movements might benefit from focusing their efforts on one party. However, this will make it much more difficult for them to reach the agenda when the opposing party controls Congress.

Fortunately for movements, the party cartel does not always get its way. While the majority rarely gets rolled, it is not immune to this phenomenon. Movements cannot change the rules and norms granting majority leaders' monopoly power, but they could limit the party's ability to use this power. Acknowledging that presidents, interest groups, and the public can increase the costs of exercising gatekeeping power, Cox and McCubbins claim the majority party may choose not to use it. Instead of holding a bill up in committee, leaders might attempt to package "sour pills" with "sweeteners" (i.e., put it in an omnibus bill with other items), or allow the party to get rolled and hope the president or the Senate stops the bill from being enacted. This more nuanced theory demonstrates how social movements could, by raising the costs of agenda control, gain some leverage over the majority party.

How might they do this? There are a number of possibilities. If the movement has strong minority party allies on the committee, they might be able to bargain with their majority party colleagues. They could also raise a bill's visibility through protests and other activities. The public cannot possibly keep track of all bills before Congress, even those for which there would be significant support in the electorate. While it might look bad for the party to defeat a popular bill in a vote, a committee could obstruct its passage quietly by bottling it up in committee. Grassroots movements could make this more difficult by raising a bill's salience.

Discharge petitions have provided another way for social movements to circumvent the majority party's monopoly power since the enactment of a new rule in 1924. With signatures from a simple majority of House members (218), petitioners can force a bill out of committee and onto the floor for a vote. This is not an easy task, however. Not all members of Congress who would be willing to vote for a bill on the floor will necessarily be willing to sign a discharge petition, an action that would most likely be viewed as hostile by the same majority party leaders who distribute committee assignments and other rewards and punishments. Of the 597 petitions 
filed between 1931 and 2006, only 48 (8 percent) reached the 218 signature threshold. This may not be as dire as it seems at first, however; even if a petition does not reach this threshold, it can make its way to the floor through other channels. Indeed, Beth (2003) finds that 16 percent of discharge efforts ultimately achieved floor attention. This suggests that highly motivated allies can make a difference for movements in the House.

Unsurprisingly, legislators' willingness to sign petitions today depends on their party's status in the chamber. This has not always been the case. Pearson and Schickler (2009) find that "for much of the twentieth century, majority party members demonstrated little reluctance to sign discharge petitions" (Pearson and Schickler, 2009: 1253). This was due largely to the split between Northern Democrats and their Southern colleagues, whose seniority granted them disproportionate power in the committee system. Many of the petitions signed by Northern Democrats during this time were on subjects of particular interest to social movements, like labor, civil rights, housing, and social security. This trend did not last, however. Pearson and Schickler note that majority party members now rarely support discharge petitions. In 2006, they find that only 11 of 235 Republicans in the House signed even one petition, and only 8 of these 11 supported more than one. Democrats, on the other hand, supported more than half of the discharge petitions filed in the same year (13 of 18, on average).

Despite this resistance from the majority party today, discharge petitions remain a potentially useful tool for movements. As Pearson and Schickler note, "discharge petition politics in today's era of strong parties should not be confused with absolute majority party gatekeeping power: as the successful Shays-Meehan/McCain-Feingold campaign finance example from the $107^{\text {th }}$ Congress makes clear, the discharge procedure remains a viable option for cross-party coalitions when an issue is salient enough for dissident majority party members to buck their leadership" (Pearson and Schickler, 2009: 1254). Movements may be able to influence a bill's salience through protests, marches, and other highly visible activities. Of course, this option will be most viable for movements whose goals are supported by at least some members of both parties. Movements with strong party identifications, like those concerned with abortion, are less likely to benefit from discharge petitions.

Even bills that are successfully discharged from the committee to which they were originally assigned need to pass through the House Rules Committee before reaching the floor, however. The danger here is not obstruction, but the assignment of an unfavorable rule. The Rules Committee sets parameters for consideration of each bill in the House. It decides, for 
instance, how much time the floor will have to debate the bill, and whether or not amendments will be allowed. Under an "open rule," members of the House may offer an unlimited number of amendments. In contrast, a "closed rule" bars all amendments - the floor must approve or reject the bill as written. Though this may sound benign, it can and often does have great consequences for bills' fate. From a movement's perspective, an open rule could allow members of the House to amend its preferred bill beyond recognition. It could also lead to an avalanche of alternatives that ultimately delay progress. In sum, the Rules Committee has powerful means to subtly doom bills they dislike. Having allies on this seemingly unglamorous, but important committee would be extremely useful for movements. Not all legislatures will have a committee exactly like this. However, in studying movements' interactions with legislatures, it is important to investigate how the chambers of interest determine the rules governing bill consideration, and pay close attention to any players in the legislative arena who have special decision-making authority in this area. If a movement appears to be underperforming, relative to its apparent support in a legislature, rulemakers - sitting under the radar with powerful tools - could be to blame. Courting their support could have subtle but significant payoffs for movements.

Movements are also likely to benefit from having allies in key chamber leadership positions. Even once a bill gets to the floor in the House of Representatives, it does not automatically fall into the hands of a supportive coalition of lawmakers. It still has to clear more gatekeepers. Party leaders, particularly the Speaker of the House, have powers and responsibilities that can strongly influence the fate of bills of interest to social movements. The Speaker of the House has more formal power than any other member of the chamber, and this power has increased since the 1970s. The Speaker's power comes from their influence over the flow of the legislative process (e.g., referring bills to committees, presiding over roll-call votes, etc.). Importantly, the Speaker also has and can grant recognition within the chamber. Members of the floor must wait to be "called on." This means that the Speaker could stop someone from introducing an amendment by refusing to recognize that person. Thus, it would be very difficult for a social movement to get a bill past a hostile Speaker.

Of course, not all legislative chambers grant these kinds of powers to their leaders. The House of Representatives is a special type of institution with strongly centralized leadership. In this context, even social movement bills that have widespread support among lawmakers may fail to make progress. Indeed, because of leaders' power to bottle up bills at multiple stages in the 
legislative process, lawmakers may not even have an opportunity to demonstrate their support in a roll-call vote. More egalitarian chambers, like the Senate, are not necessarily easier for social movements to navigate, however. They come with their own set of hurdles. Scholars studying movements in countries with relatively egalitarian legislatures may observe challenges similar to those faced by movements attempting to influence the Senate.

Historically, the Senate has tended to be more collegial than the House, owing largely to its relatively small size. With fewer members, there is less of a need for centralized leadership to control access to the agenda. Thus, committees and majority party leaders are far less powerful in the Senate than the House. Every Senator has the "right of recognition" (i.e., they can talk for as long as they want) and the chamber lacks a "germaneness rule" (i.e., its members can talk about anything, even if it is not related to the bill on which they asked to be recognized) and a "previous question" rule (i.e., the rest of the chamber cannot vote on the question until the person on the floor is done speaking).

This has a few implications for movements. While the chamber's egalitarian nature may make majority party allies less valuable, it heightens the utility of minority party allies. Whether it offers individual movement allies more or less power is not necessarily clear, however. In one sense, it makes individual Senators more influential because they can make sure the movement's bill receives recognition on the floor. In the absence of a germaneness rule, an ally could even discuss the movement's bill in a debate about another issue. However, the Senate's egalitarian ethos also enables its members to employ damaging dilatory tactics like the filibuster. Through their right of recognition, one member can theoretically hold the floor and delay a vote indefinitely. This processes derailed many civil rights bills that passed the House in the first half of the twentieth century. Since 1917, Senators have been able to end a filibuster through a motion for cloture, but this requires support from three-fifths of the chamber (6o votes in the contemporary Senate). ${ }^{2}$

One might question the importance of filibusters, since we rarely see such spectacles in contemporary American politics. Gone are the days when Senators would hold the floor for hours on end, reading from cookbooks and dictionaries to delay consideration of bills they disliked (often civil rights measures). Given Congress's enormous workload, such dramatic obstruction

2 Cloture initially required support from two-thirds of the chamber, but a 1975 amendment reduced the burden to three-fifths. After a successful cloture motion, debate is typically limited to 3 o hours and all amendments must be germane. 
would create a prohibitively costly logjam today. Just because we see very few filibusters does not mean they no longer matter, however. It is simply accepted that almost all bills will require supermajority support to pass the Senate, and few reach the floor if they are not expected to meet the 6o-vote threshold. Though bills still technically need a majority to pass the Senate, Wawro and Schickler (2010) argue that the chamber has essentially become a supermajoritarian institution.

What does this mean for movements? If they want to pass new legislation, they are likely to need more allies today than they did in the past. This increases the difficulty of legislative success, since collecting more allies often requires more work. It can also influence the substance of legislation, as building a larger coalition generally requires more compromise. Movements that are unwilling or unable to move off strong positions will have a very difficult time pushing new legislation through today's Senate. If the movement's goal is to stop legislation from being enacted, however, obstruction can be very useful. A relatively small minority of allies within the Senate can reduce the chances that a bill will reach a vote. By signaling to party leaders that they are prepared to fight against the bill, they might convince those leaders that consideration would be too costly.

The tricky thing is, these two scenarios require very different arrangements of allies. This dilemma is not unique to the Senate. Having many casual allies may benefit the movement in some situations (i.e., gaining supermajority support in the Senate for cloture, discharging a bill from committee in the House, passing a bill in either chamber, etc.), while a few highly committed allies may benefit the movement in others (i.e., obstructing an unfavorable bill in the Senate, getting favorable rules for bill consideration, etc.). While it is not impossible to have both, movements with limited resources may need to prioritize. Whether it is more beneficial to have a few close allies or many casual sympathizers will depend on the movement's goals. And, of course, the nature of the movement's aims - how extreme its preferences are in comparison to the median voter's - will strongly influence the feasibility of gaining widespread support in Congress.

\section{Navigating a Polarized Legislature}

It would be impossible to write a full analysis of parties and legislators without reference to political polarization, one of the most remarkable phenomena in contemporary American politics. In 1950, the American Political Science Association's Committee on Political Parties released a 
report criticizing the parties for being too similar. If the parties do not offer voters clear policy alternatives, the report argued, the electorate does not have a meaningful choice in elections, and democracy cannot function properly. This is not a complaint we hear very often today. Since the early 1970 , the parties have become more internally homogenous and externally distinct (McCarty et al., 2006). More votes break on party lines, and bipartisan coalitions are less common today than in the mid-twentieth century.

Whether this is good or bad for movements is not necessarily straightforward. On the one hand, party line voting eases coalition building within parties. This kind of efficiency is especially valuable for groups without many resources. On the other hand, it makes constructing bipartisan coalitions extremely difficult. Polarization's implications for movements also depend on their goals. Movements wishing to block new legislation may welcome the gridlock caused by parties' inability to find common ground. For those seeking to enact new legislation, however, polarization can pose a significant burden. Indeed, over the past few years, it has been difficult for Republicans and Democrats to negotiate successfully, even when the stakes have been high.

Just because movements face difficulties in convincing members of the opposing party in Congress to support their goals does not mean they will be unable to influence their constituents, however. Polarization has caused tension between the party in government and the party in the electorate, as many scholars argue that polarization has not increased at the mass level (DiMaggio et al., 1996; Fiorina, 2005). The alleged "culture war" is vastly overblown, despite the media's enthusiastic attention thereto, they argue. While parties may have clear menus of issue positions (i.e., opposition to legislation on climate change "goes with" opposition to abortion in the Republican camp), people do not have such clearly correlated issue positions (Baldassarri and Gelman, 2008). This is significant for social movements because it means they have a chance to persuade people of both parties to support their positions, at least on some issues.

Of course, legislators will not necessarily respond to rising public support for movement goals. Recent work on gay rights issues suggests that polarization depresses responsiveness to public opinion (Krimmel et al., 2013). Public support for gay rights has increased significantly over the past 20 years, to the point where there are now majorities in support of many gay rights policies. On some issues, the support is overwhelming. For example, majorities favor a law protecting gays and lesbians against employment discrimination in almost every district in the nation. Yet, support in Congress has been much less strong. There is a significant 
partisan dimension to this gap between opinion and legislative behavior, as Democrats have increasingly supported gay rights as public support has grown, while Republicans have not. Instead of following the median voter in their state or district, Republican members of Congress appear to be voting in accordance with their party's conservative position. This suggests that gains in public support, even in conservative districts, will not lead immediately to commensurate policy gains for the LGBT movement. That said, more legislative successes have come as public support has risen. Working to influence the public may not bring quick legislative gains, but it is unlikely to hurt and may help the movement in the long run.

\section{Conclusion}

This chapter has reviewed the players and arenas associated with political parties in legislatures, based primarily on observations about the US Congress. Scholars studying other nations may find some parts of this analysis more relevant to their cases than others. Even if one is examining a legislature with very different properties than the Congress, this analysis suggests some important questions to consider. Specifically: Who controls access to the agenda? How many people have the authority to unilaterally obstruct a bill's progress? What rules govern debate and amendment on the floor? Are rules set, or does a body like the House Rules Committee tailor them to each bill? How centralized is the leadership? What size coalition is necessary to reach a vote and/or pass a bill? Are bipartisan or multi-partisan coalitions possible? Answering these questions will help to map the arenas that movements and their allies must navigate and provide insight into the number and nature of allies necessary to achieve legislative success.

If there is one bottom line in the United States, it is that pressing bills through Congress is very difficult, even for a movement with elite allies. Social movements with legislative goals face significant hurdles, particularly if they aim to enact new legislation. While elite allies are certainly helpful, even those most committed to the movement cannot guarantee success in a deliberative body like a legislature. Some will face more difficulties than others, however. All elite allies are not equal, especially in chambers with strongly centralized leadership, like the House of Representatives. Lawmakers in leadership positions will have more powerful means to pursue movement goals than members with less authority. However, even leaders' influence will vary over time, as political contexts change. On the whole, allies' utility depends very much on their position within Congress 
and the balance of power in government at the time. A sympathetic Speaker of the House can be immensely valuable; but, even they cannot curb the threat of filibuster in the Senate.

One of the great dilemmas facing social movements is that different types of elite allies are useful in different situations. Given the tremendous competition for agenda space in the modern Congress, having a few highly motivated allies can be useful. A small cadre of committed allies can also help movements block unfavorable legislation in the Senate. In other situations, having a broader base of support is more helpful. To achieve consideration from today's supermajoritarian Senate, a movement's bill will most likely need a coalition of 60 allies. It is difficult - though certainly not impossible - to inspire fierce commitment from a few allies and diffuse support from a broader group. Stringent positions will most likely motivate the former, while more moderate positions will probably be necessary to recruit the latter.

Movements face another critical dilemma in choosing a party identification strategy. Should they try to build a bipartisan network of supportive allies or develop a more exclusive relationship with one party? Attempting to maintain relationships with both parties can be difficult. If their allies face pressure from party leaders to vote a certain way, their coalition could crumble in a vote. Building a bipartisan coalition is especially difficult when political polarization is high, as it is in the United States today. However, party affiliation comes with its own challenges. Studying the relationship between African-Americans and the Democratic Party, Frymer (1999) argues that party affiliation can lead to "electoral capture." When a group throws its support behind one party, and is also rejected by the opposing party, its ally has little incentive to act on its behalf. With limited political mobility, a captured movement cannot credibly threaten to defect from its ally party.

The barriers discussed in this chapter are not necessarily fixed. Aldrich (1995) argues that parties are endogenous institutions, which evolve in response to changing historical conditions. Rules, norms, and routines may be parametric for individual legislators, especially in the short term, but they are ultimately endogenous for the collective, and in the long run. Even if movements cannot easily influence these rules, norms, and routines, it is certainly in their interest to be aware of them. This will help them determine how to use resources most efficiently and to identify when political conditions will be most auspicious for legislative gains. 


\section{References}

Adler, E. Scott, and John Wilkerson. 1947-2008. Congressional Bills Project. NSF oo880o66 and 00880061. The University of Washington. Available at: www.congressionalbills.org.

Aldrich, John H. 1995. Why Parties? The Origin and Transformation of Political Parties in America. Chicago: The University of Chicago Press.

American Political Science Association. 1950. "Toward a More Responsible Two-Party System: A Report of the Committee on Political Parties." American Political Science Review, Supplement XLIV.

Baldassarri, Delia, and Andrew Gelman. 2008. "Partisans without Constraint: Political Polarization and Trends in American Public Opinion." American Journal of Sociology 114: 408-446.

Beth, Richard. 2003. The Discharge Rule in the House: Recent Use in Historical Context. Congressional Research Service Report for Congress. 97-856. Washington, DC: The Library of Congress.

Cox, Gary W., and Mathew D. McCubbins. 2005. Setting the Agenda: Responsible Party Government in the US House of Representatives. New York: Cambridge University Press.

DiMaggio, Paul, John Evans, and Bethany Bryson. 1996. "Have Americans' Social Attitudes Become More Polarized?" American Journal of Sociology 102: 690-755.

Farhang, Sean, and Ira Katznelson. 2005. "The Southern Imposition: Congress and Labor in the New Deal and Fair Deal." Studies in American Political Development 19: 1-30.

Fiorina, Morris P. 2005. Culture War? The Myth of Polarized America. New York: Pearson Longman.

Frymer, Paul. 1999. Uneasy Alliances: Race and Party Competition in America. Princeton: Princeton University Press.

Katznelson, Ira. 2005. When Affirmative Action Was White: An Untold History of Racial Inequality in Twentieth-Century America. New York: W. W. Norton.

Key, V.O., Jr. 1942. Politics, Parties, and Pressure Groups. $1^{\text {st }}$ ed. New York: Thomas Y. Crowell.

-. 1964. Politics, Parties, and Pressure Groups. $5^{\text {th }}$ ed. New York: Crowell.

Krehbiel, Keith. 1991. Information and Legislative Organization. Ann Arbor: University of Michigan Press.

Krimmel, Katherine. 2013. "Special Interest Partisanship: The Transformation of American Political Parties." PhD diss., Columbia University.

Krimmel, Katherine, Jeffrey Lax, and Justin Phillips. 2013. "Gay Rights in Congress: Public Opinion and (Mis)Representation." Working paper.

Los Angeles Times. 1993. “Voices." Los Angeles Times, July 20. Available at: http://articles.latimes. com/1993-07-20/news/mn-15033_1_traditional-values-coalition.

Mayhew, David. 1974. Congress: The Electoral Connection. New Haven: Yale University Press.

McCarty, Nolan, Keith T. Poole, and Howard Rosenthal. 2006. Polarized America: The Dance of Ideology and Unequal Riches. Cambridge: MIT Press.

Pearson, Kathryn, and Eric Schickler. 2009. "Discharge Petitions, Agenda Control, and the Congressional Committee System, 1929-76.” The Journal of Politics 71: 1238-1256.

Rimmerman, Craig A. 1996. "Promise Unfulfilled: Clinton's Failure to Overturn the Military Ban on Lesbians and Gays." In Craig A. Rimmerman, ed., Gay Rights, Military Wrongs: Political Perspectives on Lesbians and Gays in the Military. New York: Garland Publishing.

Soule, Sarah A., and Brayden G. King. 2006. "The Stages of the Policy Process and the Equal Rights Amendment, 1972-1982." The American Journal of Sociology 111: 1871-1909.

US Senate. 2013. Resume of Congressional Activity. 3 January. Available at: http://www.senate. gov/pagelayout/reference/two_column_table/Resumes.htm.

Wawro, Gregory J., and Eric Schickler. 2010. "Legislative Obstructionism." Annual Review of Political Science 13: 297-319. 



\title{
4 Contentious Governance
}

\author{
Local Governmental Players as Social Movement Actors
}

\author{
Imrat Verhoeven and Christian Bröer
}

Over the past decades the role of government in policy making and implementation has changed in many countries. Incited by reforms toward new public management, marketization and privatization coupled to participatory democracy, centralized bureaucracies have given way to loosely structured, sometimes fragmented, governance networks (Bevir, 2010: ch. 4). These networks do not appear in every field of policy: they are, for example, more pronounced in social and environmental policies in the Global North and around aid-dependent policies in the Global South. As a counter tendency, securitization policies tend to strengthen central governments.

Depending on the field, policy conflicts are often embedded in networks, a process we propose to call "contentious governance." Analytically, the idea of contentious governance unhinges mainstream social movement theorizing on the role of government in processes of contestation. The dominant political process perspective assumes that government is a more or less unified actor to mobilize against, to seek support of or to be seen as the "context" that provides opportunities for or threats to mobilization (Jasper, 2011: 5). From a contentious governance perspective, there is no "government" as such that engages with protestors; instead we encounter a plethora of governmental players in contentious interactions with each other and with other players.

The idea of contentious governance also problematizes Charles Tilly's (1978) influential distinction between state and movements that situates movements outside of the state. Many cases can be found in which governmental players together with movements and other civil society organizations fight for the same cause. We encounter governmental players that behave "social movement-like" by mobilizing citizens to support their claims in policy conflicts with other governmental players. In these cases governmental players become movements, at least for a while, thus blurring Tilly's distinction between state and movements.

In this chapter we will focus on episodes of contentious governance in which governmental players behave social movement-like, because these cases push our understanding of contentious governance the furthest. 
More specifically, we analyze mobilization by governmental players during policy conflicts with other governmental players. Examples of this are the protests against aircraft noise in the UK (Griggs and Howarth, 2004) and Switzerland (Bröer, 2007); some cases of opposition to energy projects in the United States (McAdam and Boudet, 2012); and fierce conflicts about nuclear waste storage in Germany (Gorleben), where local governmental players sometimes oppose storage.

Our analysis will build on the strategic perspective suggested by Jasper (2015) and the introduction to this volume. We will analyze the strategic interactions between governmental players in policy conflicts and the opportunities and constraints that these interactions impose on the social movement-like behavior of the opposing governmental players. Our focus lies on how governmental players seize and create these, sometimes discursive (Bröer and Duyvendak, 2009), opportunities during strategic interactions with their governmental opponents.

We analyze two cases of contentious governance in the Netherlands to show how governmental claimants strategically interact with governmental proponents of contested policies, with bystanders, and with publics they seek to mobilize. An abundance of cases is to be found in the Netherlands where lower tiers of government mobilize against policy plans advanced by regional or national authorities. The Dutch context is very interesting to study such cases because of the tension between a strong tradition of consensus-building through negotiations (Hendriks, 2009; Lijphart, 1968) and contentious behavior that pushes the boundaries of governance practices.

The first case to be analyzed is a process of municipal amalgamation researched by Verhoeven in his doctoral thesis (2009). Municipal amalgamation, merging municipalities by the redrawing of polity boundaries, is itself part of a restructuring of governance relations. We will show how attempts to concentrate political power are opposed by governmental players. The second case focuses on local protests against the siting of mobile phone antennas (Bröer et al., 2012). Here, the conflicts over mast siting involve national and local government and the telecom industry. We will show how local governments rally for a stakeholder position, thereby enacting governance, even in the absence of legal rights.

Before we dig into the cases we will elaborate on the idea of contentious governmental players and various empirical manifestations that can be found in the literature related to this topic. 


\section{Contentious Governance and Governmental Players}

Research on mobilization has been social movement centric, obscuring the role of other players in recruiting activists and framing issues (McAdam and Boudet, 2012: 2; see also Jasper, 2015). The active involvement of governmental actors to mobilization seems understudied. This needs to be addressed particularly in a situation of conflicts within dispersed and displaced policy networks or contentious governance, as we call it. To better understand governmental players in this respect we first need to be more precise on what we mean by contentious governance.

Contention is commonly understood to be a process of claims making by non-state actors in which the state is either the target of or a third party to claims. Often overlooked is the suggestion in the contentious politics literature of governmental players performing as "initiators of claims," seeking to alter or redress a problematic situation (McAdam et al., 2001: 5; Tilly and Tarrow, 2007: 4; Tilly, 2008: 5). Of course initiating claims is part of the core business for governmental players and politicians. This is sufficiently demonstrated in social problem research (Spector and Kitsuse, 1987; Hilgartner and Bosk, 1988). However, claims making in those cases is a strategy for seeking legitimacy. In this article, we look at governmental actors that mobilize discontent.

Initiating claims in a social movement-like manner is a process that we relate to the increasing prominence of governance. We suggest that the dispersion of governance networks since the 1980 os has increased the number of actors involved in policy making (Bevir, 2010), decreased power imbalances, and increased the number of arenas. While the figuration as a whole might have become more complex, the network structure allows for more room to maneuver for every single actor. The network structure also increases the potential for conflicts of interest because there is no clear hierarchy and no single compound player is powerful enough to make authoritative decisions on its own (Hajer, 2009). Lastly, governance networks are coordinated foremost by "language" or shared symbols and assumptions (Hajer, 2009).

The social movement literature provides some cues how to relate these developments in governance to mobilization by governmental players. According to Amenta and Zylan (1991: 252), the agency of governmental players largely depends on their autonomy: "The greater their autonomy, the more likely that state actors will pursue their own agendas, including the support of like-minded challenges. As bureaucrats try to expand the powers of state institutions, they may encourage movements with similar 
goals." In a governance context, governmental players experience more autonomy due to processes of decentralization, devolution of power, and deregulation. Governmental players may spur challenges that help their cause: "State civil servants can be seen as members of the polity interested in expanding their own power as well as advancing their ideas of the public interest. To promote their goals, state actors may selectively spur challenges" (Amenta and Zylan, 1991: 263). Here we clearly see the suggestion of governmental players performing as claims makers with the potential to mobilize bystanders to support their claims vis-à-vis governmental or other players. This potential may materialize whenever governmental players get stuck in policy controversies dominated by frame pluralism and stalemate (Rein and Schön, 1993: 147-150; Laws and Rein, 2003: 174; Meyer, 2005: 7). Instead of trying to reframe the situation (Rein and Schön, 1993) they can choose to behave social movement-like.

To put social movement-like behavior by governmental players in perspective we may see it as one manifestation of contentious governance next to institutional activism and facilitation through issue coalitions. Institutional activism can be found in what Lee Ann Banaszak (2005) has called "state movement intersections," consisting of overlapping memberships. State officials may also be movement activists participating in social movement organizations or participants in unorganized or spontaneous activities by these organizations. Likewise, movement activists may become state officials while retaining their movement connections. These institutional or insider activists, Banaszak argues, influence the development, strategies, and outcomes of movements because they most often employ insider tactics. Her empirical analysis of the intersections between state officials and the women's movement in the United States indeed indicates that institutional feminist activists focused on non-protest activities such as taking legal action and informing the movement about political opportunities, although many also participated in protest activities (Banaszak, 2005: 167-168). In addition, David Pettinicchio (2012:502) identifies other activities of institutional activists, such as framing the problem or possible remedies; creating policies, programs or even agencies to support movement claims; creating new political opportunities for movement actors; and encouraging activism within the government. In all these actions we clearly see that institutional activists are quite proactive, that they use their access to resources and employ their influence on policy making to help the good cause (Pettinicchio, 2012: 502).

A more collective way for governmental players to become involved in contentious governance is to facilitate mobilization by and participate in 
issue coalitions. Many examples can be found in the wide spread of community coalitions against substance abuse in the United States since the $1990 \mathrm{~s}$ (McCarthy, 2005: 90-93). Governmental, corporate, and civil society elites, involved in the US “War on Drugs," facilitate and participate in community coalitions that press for substance abuse reduction. The governmental players are either individual government officials or compound players such as law enforcement agencies or alcohol and drug prevention agencies (McCarthy, 2005: 93). Governmental facilitation takes the form of extensive funding, of moral resources such as endorsement by public figures, or of informational resources such as strategic and technical support (McCarthy, 2005: 104-105).

An early example of government-social movement coalitions can be found in Japanese anti-pollution politics between 1956 and 1976, including state agencies, opposition political parties, local governments, and the courts (Brewster Stearns and Almeida, 2004). Other examples are the affiliations between oppositional political parties and the anti-nuclear weapons movement in the Netherlands during the mid-1980s (Kriesi et al., 1995). The direct involvement of governmental players in coalitions with social movements indicates that the boundaries between government and movements sometimes become very fuzzy: working toward the same goals has led to interpenetration of governmental players and movements (Wolfson, 2001; compare Sampson et al., 2005, on hybrid events).

Compared to institutional activism and the facilitation of coalitions with movements, social movement-like behavior by governmental players is the most extreme form of contentious governance. With social movement-like behavior it does not make sense anymore to talk about a state-movement dichotomy that is bridged by state movement intersections provided by institutional activists, nor do we need to discuss the fuzziness of the boundary between governmental players and movements. Instead governmental players become social movement-like, at least for a while, by directly mobilizing bystanders to support their cause in a policy conflict. How this form of governmental activism works will be analyzed in the Dutch cases of municipal amalgamation and cell-phone mast siting.

\section{Municipal Amalgamation of the Hague's Vicinity}

Processes of municipal amalgamation entail that smaller municipalities are merged partly or entirely with bigger municipalities. One of the most controversial and extensive Dutch processes of municipal amalgamation 
was that of the city of The Hague and its vicinity in the period 1997-2001 (Verhoeven, 2009). In the late 1990s the city of The Hague, home to the Netherlands' national political institutions, found itself in deep financial problems due to the flight of the middle class to neighboring municipalities and a sharp decline in tax revenues. The suggested solution was to build new homes to attract middle-class residents and develop infrastructure to support "creative industries." The Hague needed space to implement these plans but had none within the city limits.

After several attempts to address this problem, the issue became so highly politicized that the national government and parliament intervened. In the end, in May 1997, the Dutch parliament decided that municipal amalgamation would be the best solution. In this case the five municipalities of Rijswijk, Leidschendam, Voorburg, Pijnacker, and Nootdorp would have to give up parts of their territory to The Hague. The main target of the amalgamation process consisted of new housing estates (Leidschenveen and Ypenburg), (post)industrial sites and office locations that were developed by some of these municipalities and a corridor to connect these sites with The Hague's territory, which was planned to pass through established neighborhoods in Rijswijk, Voorburg, and Leidschendam. Over the whole 1997-2001 time period 1998 and 2000 proved to be the years in which contentious governance between proponents and opponents reached it peaks.

\section{8: Intense Governmental Contestation}

From the summer of 1997 onward into the early spring of 1998 two opposing governmental coalitions were formed. The strong block of proponents consisted of the provincial authorities of Zuid-Holland (a regional tier of government), mandated by the Minister of the Interior to take charge of the planning process, and the city of The Hague lobbying for maximum territorial gains. The governmental claimants opposing the plans were the five municipalities of Rijswijk, Leidschendam, Voorburg, Pijnacker, and Nootdorp, later on joined by ad hoc citizen action groups, and achieving significant discursive resonance through an influential regional newspaper De Haagsche Courant. Before the provincial authority announced its initial plans for municipal amalgamation in April 1998, the governmental claimants had shifted gears from negotiations and lobbying to a collective action strategy, leading to the first peak in contentious governance. To legitimize their social movement-like behavior they had developed the political slogan "Cooperation yes, annexation no," which was consequently employed to communicate their anti-annexation frame. Thus they created a discursive 
opening for themselves reacting to the proponents' "Give The Hague space" frame. Working from their anti-annexation frame the governmental claimants started out by creating opportunities for mobilization that fitted into the ongoing stream of strategic interactions with the proponents.

As soon as the provincial plan became clear, the five municipalities organized information evenings to explain what was about to happen and for citizens to voice their opinions. An estimated 2,00o citizens (from all five municipalities) attended. These meetings also functioned to mobilize citizens to start up their own local ad hoc anti-annexation action groups (in Dutch: Anti-Annexatie Comités, AACs). The municipalities stated that they would provide each AAC with resources like money and advice by public relations consultants. By doing so, they created an opportunity for citizens to become active. Citizens quickly responded, and within a very short time frame of up to three weeks AACs were established in all five municipalities. The AACs tried to operate as independently as possible from the governmental claimants as they thought that their fellow citizens might otherwise not trust them. Interestingly, this strategic distancing did not diminish the AACs importance as collaborators for the governmental claimants.

The governmental claimants created another opportunity for protest in June 1998. A survey from that period indicated that 98 percent of the total population in the five municipalities knew about the plan and 93 percent were against it. A massive poster campaign against the plan of the provincial authority visualized and further stimulated discontent. A grand total of 100,000 anti-annexation posters were printed for an estimated population of 152,000 inhabitants of the five municipalities. The AACs helped to distribute the posters practically door-to-door, just before the summer holiday. Many of the posters were indeed put up behind windows; pictures from that period show that in some areas, every house had the poster on display.

During the summer of 1998 the provincial authority had to fulfill procedural requirements concerning their plan. They had to organize open information evenings and offer the possibility for citizens to send in notices of objection. The governmental claimants reacted strategically by suggesting to the AACs that these were opportunities for protest. The AACs picked up on these suggestions very quickly. The first information evening of the provincial authority in late June was turned into a demonstration of 4,500 people, where the provincial authority had expected a maximum of 1,500 attendees. A second meeting was organized in early July, which was attended by yet another 1,500 people. The opportunity to file notices of objection against the provincial plan from June to the beginning of September was also seized by the AACs. They started an intensive campaign that lasted 
three months, and succeeded in getting 23,500 notices of objection by individual citizens (roughly one-sixth of the population) over the summer holiday. By mobilizing citizens during the summer of 1998, the AACs helped the governmental claimants to retain their distance from organizing forms of protest that could easily alienate them from the powerful proponents of municipal amalgamation.

The governmental claimants were in a powerful position to create an opportunity for mobilization. In October 1998, they organized a non-binding referendum for which they did the mobilization themselves, with some help from the AACs. They organized an intensive information campaign publishing newsletters (75,00o copies per edition) alongside advertisements, posters, and letters delivered to each household. The day before the referendum they organized the largest instance of mobilization during the whole process of contention. All municipal politicians and civil servants went out on the street, together with volunteers from the AACs, to literally go door-to-door, asking people whether they would come out to vote. They were rewarded by a massive turnout on referendum day. Of the 122,000 citizens older than 18 called upon, 90,00o came to vote and 98 percent voted against the plan by the provincial authority. These turnout numbers confirmed the support for the anti-annexation frame and the claims making by the governmental opponents.

In December 1998, the odds turned against the provincial authority. After losing a legal battle on a procedural technicality provincial politicians feared losing too many votes during upcoming elections if they would proceed with the amalgamation process. Before the year ended, they returned their mandate to the Minister of the Interior. He had to take charge of the municipal amalgamation procedure and develop a tangible plan to reach closure in this contentious governance process.

\section{0: Walking the Thin Line between Contestation and Negotiation}

The peak in contentious governance from the spring to December 1998 was followed by a quiet period, which ended when the Minister of the Interior revealed his plans for municipal amalgamation in April 2000. With the minister in charge, the governmental claimants sensed that they had to be more careful in their claims making because the minister's plan would be finalized in a law regulating the municipal amalgamation process.

The minister's unveiling of his plan in April 2000 shocked three of the five municipalities: they would now have to cede much more territory than under the provincial plan of 1998. Two out of the five organized open information evenings for their citizens; one was attended by 2,00o people 
and from the other no numbers are available. The governmental claimants did not organize much collective action themselves in this phase of the strategic interactions; they pinned their hopes on the local citizen action groups to mobilize citizens once again. Although there were actually numerous procedural steps the minister had to follow, the AACs did not seize them as opportunities for mobilization, except for one they were already familiar with from the summer of 1998. From the end of April until mid-July 2000, the minister's plan was disclosed for public scrutiny and citizens could send in notices of objection. The AACs managed to mobilize 28,000 citizens from four of the municipalities to do so, which was one-fifth of their population at the time.

The public pressure made the minister decide to alter his plan in such ways that significant parts of the territory of old neighborhoods required for the corridor connecting the new housing estates to The Hague's territory were no longer at stake. From this moment onward the governmental claimants deserted their strategy of contention and completely switched to lobbying and negotiations geared toward altering details of the plan during parliamentary debate on the proposed law. In the end the whole amalgamation process took almost five years and was officially completed on 1 January 2002. The new housing estates became part of The Hague, but the rest of the territory of the five municipalities remained unaffected.

\section{Protesting Mast Siting}

The siting of mobile phone technology - base stations and antennas - is contested in many countries and locales worldwide. Protests in Europe and the United States are documented quite well (Borraz, 2011; Burgess, 2004; Drake, 2006; Stilgoe, 2005). But also outside these countries we find action against mobile phone technology, for example, in the Philippines and in Ghana. It is safe to say that global mobile phone technology has a different footprint locally, partly because of local contestation. A point of discussion is the question if these protests testify to NIMBY-ism and irrationality (Law and McNeish, 2007; Soneryd, 2007). In the Netherlands the GSM, UMTS, and LTE (fourth generation) network use about 25,000 base stations at present.

\section{5-1999: Stopping the Roll-out}

From 1975 onward the siting of radio towers has been an object of debate and incidentally of contention in the Netherlands. Land use, interference with 
household appliances or health effects were mentioned in these cases. The advent of the second-generation - GSM - cellular network beginning in the 1990 initiated protracted conflicts in about 15 percent of all municipalities. Councils and aldermen played a significant role in these conflicts.

The siting of GSM antennas in most cases fell within the jurisdiction of municipalities. As part of spatial planning policy, a building permit was required. Local governments adapted this opportunity to oppose the roll-out of GSM technology. From 1994 onward, we witness the first local protests, in about ten municipalities. One of them turned out to be crucial: Haarlemmermeer, a medium-sized municipality close to Amsterdam. There, a handful of citizens objected to the installation of a base station on the top of their rental apartment building. They mainly reported increasing health complaints and started to survey health conditions. While the aldermen initially did not want to interfere with the roll-out, the municipal council embraced citizens' concerns and pressured the aldermen to adopt a different policy. The main argument was uncertainty about health effects. In that sense, local politicians adopted the national political and scientific discourse about health effects of mobile phone technology - no proof of adverse effects but no conclusive research in the other direction either - and turned it to their advantage. They started making antenna policy. Part of this was to look at the current sites and their legal basis. It turned out that the local planning authorities had not approved most of the base stations. The municipality adapted to this opportunity and filed a lawsuit against "illegal" base stations - which they won. Moreover, they did not hand out any permits for new stations and threatened to remove the illegal ones. Haarlemmermeer used the legal framework at its disposal, thus having a huge impact on national technology implementation: several other municipalities followed their example and the roll-out of GSM technology came under serious pressure.

At that point, the national government changed spatial planning law. Antennas were largely exempted from building permit requirements. This was approved by the national organization of municipalities, after fierce internal struggle. Effectively, municipalities lost their basis for antenna policy and therefore were excluded from the governance network. In sum, municipalities adapted legal opportunities to their local agendas and opposed mast siting in cooperation with citizens. They created new opportunities for social movement-like behavior by other municipalities and legitimated their own actions by defining scientific uncertainty as a reason to stop the roll-out.

While municipal rights were curbed, their dispersed opposition delayed the roll-out of the second- and later the third-generation technology. The 
national government devised mast siting policy and coupled this to health effects, health risk research and risk communication. In that sense, the issue of the health risk of mobile phone technology was not off but firmly on the agenda. Although municipalities were no longer legally part of the governance network, citizens could enter it directly: as tenants they got a veto right if base stations were placed on an apartment building. Scientific expertise got a more pronounced role through a large funding program for mobile phone health risk research and the industry started searching for noncontentious building sites like churches or offices. In general, the industry became more dependent on other actors as well. The second phase shows how municipalities capitalized on this in a social movement-like fashion.

\section{0-2012: Regaining Power}

Most municipalities followed the new national policy and left base station siting to national authorities, the telecom industry, and the owners or inhabitants of buildings. Other municipalities played a more activist role. Precisely because they had fewer legal opportunities to be seized, they created opportunities and adapted less obvious national discourses to their cause.

Among the municipalities that oppose mast siting we see different strategies. In rare cases, local politicians actively approach citizens to start thinking about and acting on base station siting. They organize meetings for citizens, invite critical scientists and activists from other cities and mobilize citizens explicitly. In Amsterdam for example, members of the local council invited citizens to commonly devise alternative siting plans and, even broader, to scrutinize the necessity of mobile phone technology in general. Here, local politicians were able to capitalize on two existing discourses: first the widespread claim of citizens' participation in politics. Similar to the case of amalgamation described above, local politicians reasoned that they were "closest to the citizens." This legitimated their involvement in mast siting decisions. Second, local politicians used common risk thinking to establish their position. As local government, they have a right to "care" about "their" citizens.

These claims are also visible where municipalities are a bit less activist. In these cases, municipal claimants hitch on to existing citizen protest and create new opportunities for them. Municipalities organize "informational meetings" or hearings. They commission survey research to chart public opinion and propose alternative sites for base stations following objections to a particular site. In one case, local politicians point citizens to the planned 
erection of a mast and the procedural terms under which this might be opposed. Municipalities support lawsuits, organize media attention, or invite other stakeholders within the governance network. For example, in the city of Hengelo, following citizens' concerns, the municipality urged the telecom provider to search for a different base station site. This was not exactly what the local action group wanted. They urged the right to think about the spot themselves. But it put the municipality back at the negotiation and policy table with telecom providers, health researchers, and national authorities.

Regarding the cases of mast siting, the onset and development of local activism happened in two steps: first, triggered by citizens concerns, social movement-like behavior of some municipalities opposing mast siting led to new restrictive national policy and legislation. Municipal rights concerning base station siting were severely reduced. Still, in the second step we see that municipalities claim a position in decision making and reclaim entry into the governance network. Here, they act social movement-like by cooperating with local action groups (for a more detailed analysis, see Bröer et al., 2012).

Local protests also made telecom providers search for non-contentious sites. Among other measures, the industry attracted liaison managers and site-acquisition specialists and made wholesale arrangements with large institutions to get around localized opposition. While most of the base stations are in place now, the remaining spots are highly contested and the upcoming fourth generation of mobile phone communication technology (LTE) might need new sites for base stations.

Finally, although mobile phone technology and base stations can be scrutinized in several ways - land use policy, real estate value, participation, necessity - discussions tend to focus on possible health effects. Although evidence of adverse health effects is rare, it cannot be convincingly excluded. The World Health Organization (WHO) reclassified mobile phones as a "possible carcinogenic" on 31 May 2011. The Council of Europe in May 2011 advised banning the use of cell phones and wireless networks in schools, and it recommended adherence to the "as low as reasonably achievable" (ALARA) principles for EMF exposure. Municipalities can seize these opportunities if it fits their strategic interactions with higher tiers of government and corporations.

\section{Conclusion}

This chapter can be read as an attempt to bring together several lines of inquiry and point to a pattern: under the condition of governance, contention 
is more likely to see governmental players in many roles: as "the enemy formerly known as the state," as institutional activist, as a partner in a coalition, or even as social movement-like actor. A governance structure favors coordination and conflicts through symbols, language, and discourse. This points to forms of mobilization more pronounced in advanced liberal democracies; it does not address upheavals like "the Arab Spring" equally well.

Indeed, in the two Dutch cases discussed here, the traditional dividing lines between state and social movements or between government and citizens no longer apply to policy conflicts. Within a governance context governmental organizations can become embroiled in processes of contention, acting as claimants who behave "social movement-like." However, this does not imply that they become social movement organizations. Contrary to many social movements, governmental claimants are not single-issue organizations. They are always involved in many policy domains and thus have to reckon with several ongoing governance relations even with their opponents in any specific issue. Strategically, cognitively and emotionally, governance network actors depend on each other in multiple ways.

The movement-like behavior by governmental claimants is constrained by variable degrees of freedom. In the municipal amalgamation case there were stronger restrictions because the claimants always had to consider making a deal that altered the plan instead of redressing it. Protesting mast siting is less restricted by this dynamic because so many masts are required and so many sites can be considered within the municipal boundaries. The degrees of freedom for movement-like behavior also vary overtime. In the municipal amalgamation case the governmental claimants became less activist in the second episode of contention because they realized that closure had to be reached with the Minister of the Interior. In the mast protest cases we see the opposite dynamic. After they had become closed out from decision making in governance networks, various municipalities became more openly activist by adapting and creating opportunities for their citizens to protest mast siting. They reclaimed the right to make policy concerning base station siting and used contention to achieve this.

Both cases show that governmental claimants strategically react to proponents' discourses and political actions by turning them into opportunities for direct mobilization by themselves or to provide local action groups with arguments to frame their grievances and start a process of consensus mobilization (Klandermans, 1997). Using and interpreting the rules of the game is also part and parcel of governmental claimant's movement-like behavior, sometimes to facilitate their own protest - as was the case in the 
first phase of mobile phone protests - but most often to enable bystanders to use them for their own actions. Again the degrees of freedom within ongoing governance relationships seem to be the critical factor determining whether governmental actors use opportunities themselves or mediate them to local supporters of their claims. In cases with less freedom, such as the municipal amalgamation process, governmental claimants try to avoid critique from the proponents on abusing the rules of the game for behavior that may be perceived as too "unconventional."

Most movement-like behavior of governmental claimants remains rather conventional: organizing information evenings, organizing referenda or poster campaigns for the expression of protest. In both case studies they rely on a "division of oppositional labor" with local action groups and other bystanders. Often cued by governmental claimants, action groups organize forms of protest such as demonstrations or using legal procedures for protest that are perhaps too "unconventional" for governmental claimants to employ. In that sense governmental claimants seem to rely on a restricted political repertoire for their movement-like behavior. The concept of contentious governance allows us to the better understand these ubiquitous forms of protests.

\section{References}

Amenta, Edwin, and Yvonne Zylan. 1991. "It Happened Here: Political Opportunity, the New Institutionalism, and the Townsend Movement." American Sociological Review 56: 250-265.

Banaszak, Lee Ann. 2005. "Inside and Outside the State: Movement Insider Status, Tactics, and Public Policy Achievements." In David S. Meyer, Valerie Jenness, and Helen Ingram, eds., Routing the Opposition: Social Movements, Public Policy, and Democracy. Minneapolis: University of Minnesota Press.

Bevir, Mark. 2010. Democratic Governance. Princeton and Oxford: Princeton University Press. Borraz, Olivier. 2011. "From Risk to the Government of Uncertainty: The Case of Mobile Telephony." Journal of Risk Research 14: 969-982.

Brewster Stearns, Linda, and Paul D. Almeida. 2004. "The Formation of State Actor-Social Movement Coalitions and Favorable Policy Outcomes." Social Problems 51: 478-504.

Bröer, Christian. 2007. “Aircraft Noise and Risk Politics." Health Risk \& Society 9: 37-52.

Bröer, Christian, and Jan Willem Duyvendak. 2009. "Discursive Opportunities, Feeling Rules, and the Rise of Protests against Aircraft Noise." Mobilization 14: 337-356.

Bröer, Christian, Bert D. Graaff, Rik Wester, and Jan Willem Duyvendak. 2012. "Editing Interpretation: A Case Study into the Influence of Policy on Local Social Movements.” Paper presented at the $82^{\text {nd }}$ Meeting of the Eastern Sociological Society, New York, NY, February 23-26.

Burgess, Adam. 2004. Cellular Phones, Public Fears, and a Culture of Precaution. New York: Cambridge University Press. 
Drake, Frances. 2006. "Mobile Phone Masts: Protesting the Scientific Evidence." Public Understanding of Science 15: 387-410.

Griggs, Steven, and David Howarth. 2004. "A Transformative Political Campaign? The New Rhetoric of Protest Against Airport Expansion in the UK." Journal of Political Ideologies 9: 181-201.

Hajer, Maarten A. 2009. Authoritative Governance: Policy Making in the Age of Mediatization. Oxford: Oxford University Press.

Hendriks, Frank. 2009. "Democratic Reform between the Extreme Makeover and the Reinvention of Tradition: The Case of the Netherlands." Democratization 16: 243-268.

Hilgartner, Stephen, and Charles L. Bosk. 1988. "The Rise and Fall of Social Problems: A Public Arenas Model." American Journal of Sociology 94: 53-78.

Jasper, James M. 2011. "Introduction: From Political Opportunity Structures to Strategic Interaction." In Jeff Goodwin and James M. Jasper, eds., Contention in Context:Political Opportunities and the Emergence of Protest. Stanford: Stanford University Press.

—. 2015. "Introduction." In James M. Jasper and Jan Willem Duyvendak, eds., Players and Arenas. Amsterdam: Amsterdam University Press.

Klandermans, Bert. 1997. The Social Psychology of Protest. Oxford: Blackwell.

Kriesi, Hans Peter, Ruud Koopmans, Jan Willem Duyvendak, and Marco Giugni. 1995. New Social Movements in Western Europe. London: UCL Press.

Law, Ales, and McNeish, Wallace. 2007. "Contesting the New Irrational Actor Model: A Case Study of Mobile Phone Mast Protest." Sociology 41: 439-456.

Laws, David, and Martin Rein. 2003. "Reframing Practice." In Maarten A. Hajer and Hendrik Wagenaar, eds., Deliberative Policy Analysis: Understanding Governance in the Network Society. Cambridge: Cambridge University Press.

Lijphart, Arend. 1968. The Politics of Accommodation: Pluralism and Democracy in the Netherlands. Berkeley: University of California Press.

McAdam, Doug, and Hilary Schaffer Boudet. 2012. Putting Social Movements in Their Place: Explaining Opposition to Energy Projects in the United States, 2000-2005, Cambridge: Cambridge University Press.

McAdam, Doug, Sidney Tarrow, and Charles Tilly. 2001. Dynamics of Contention. Cambridge: Cambridge University Press.

McCarthy, John D. 2005. "Velcro Triangles: Elite Mobilization of Local Antidrug Issue Coalitions." In David S. Meyer, Valerie Jenness, and Helen Ingram, eds., Routing the Opposition: Social Movements, Public Policy, and Democracy. Minneapolis: University of Minnesota Press.

Meyer, David S. 2005. "Introduction. Social Movements and Public Policy: Eggs, Chicken, and Theory." In David S. Meyer, Valerie Jenness, and Helen Ingram, eds., Routing the Opposition: Social Movements, Public Policy, and Democracy. Minneapolis: University of Minnesota Press.

Pettinicchio, David 2012. "Institutional Activism: Reconsidering the Insider/Outsider Dichotomy." Sociology Compass 6: 499-510.

Rein, Martin, and Donald Schön. 1993. "Reframing Policy Discourse." In Frank Fischer and John Forester, eds., The Argumentative Turn in Policy Analysis and Planning. Durham, NC: Duke University Press.

Sampson, Robert J., Doug McAdam, Heather MacIndoe, and Simon Weffer-Elizondo. 2005. “Civil Society Reconsidered: The Durable Nature and Community Structure of Collective Civic Action." American Journal of Sociology 111: 673-714.

Soneryd, Linda. 2007. "Deliberations on the Unknown the Unsensed and the Unsayable? Public Protests and the Development of Third-Generation Mobile Phones in Sweden." Science Technology \& Human Values 32: 287-314. 
Spector, Malcolm, and John I. Kitsuse. 1987. Constructing Social Problems. New Brunswick, NJ:

Transaction Publishers.

Stilgoe, Jack. 2005. "Mobile Phone Health Risks, Controlling Mobile Phone Health Risks in the UK: A Fragile Discourse of Compliance." Science and Public Policy 32: 1-10.

Tilly, Charles. 1978. From Mobilization to Revolution. Reading, MA: Addison-Wesley.

-. 2008. Contentious Performances. Cambridge: Cambridge University Press.

Tilly, Charles, and Sidney Tarrow. 2007. Contentious Politics. Boulder/London: Paradigm.

Verhoeven, Imrat. 2009. Burgers tegen beleid. Een analyse van dynamiek in politieke betrokkenheid. Amsterdam: Aksant.

Wolfson, Mark. 2001. The Fight against Big Tobacco: The Movement, the State, and the Public's Health. New York: Aldine de Gruyter. 
Part 2

The Forces of Order 



\section{The Police}

\section{Donatella della Porta and Kıvanç Atak}

Diyarbakır, Turkey, 15 February 2009. The tenth anniversary of the capture of the PKK leader Abduallah Öcalan. Early hours in the morning, silent and empty streets left by many shopkeepers who did not open their stores contrast to snowballing crowds on several other streets where hundreds of people are fevering for the demonstration. MPs from the pro-Kurdish Peace and Democracy Party (BDP) and the municipal authorities of the same party are rushing to the police to convince them to permit a peaceful march with promises of no public order disruptions. Mayor Osman Baydemir talks to the chief officers:

OB: We definitely do not want anything like disorder.

Officer: Neither do we.

OB: I wish to share the same feelings with you.

Officer: Of course.

OB: Thus we need to behave with a shared mind... I believe that if all the people could express themselves through dialogue, no problems would occur. My suggestion is this: we will use one line of the avenue. As we did before, we will walk on this line to the front of the Fatih High School. From there on, we'd like to make our press declaration in front of the Human Rights Statue. Then we will disperse quietly.

Officer: I want to ask you this: Who is making this event? What is this event?

OB: This is an event by our provincial organization. It is not an illegal event. The vehicle of our party is here, our provincial party chief is here, and our mayor [himself] is here.

Officer: OK, but now explain to me: Do human rights in Diyarbakır only belong to the 1,500 people gathered here? What about the human rights of the one million and fifty thousand people remaining?

OB: Even if there are five people, we should let them express themselves so that they will say, "They are showing respect to us."

Officer: You could have made an application, we would have provided the security...

OB: The country will not collapse with slogans, my dear... Without any problems people will go back to their homes. Thus, with utmost 
sincerity, with utmost effort, we will do our best together with our MPs, our provincial chief, our mayors.

Officer (talking on the radio to another officer): There is another group on the Sakarya Avenue, right? OK, do what's necessary. ${ }^{1}$

This is a typical anecdote about protest policing as an arena. The police as one player of the state negotiate with another player on the street before forcefully dispersing the crowd that supposedly gathered illegally. The short scene presented above is familiar to any political activist who may have run into a similar encounter with the police elsewhere in the world. That day, Diyarbakır turned into a city of urban warfare given the clashes with the police. It could have been different if both players, the police and the protesters, had employed different strategies toward each other. Or perhaps it would not. Actually, it all depended on how those different strategies interacted with each other.

When we talk about protest policing, we tend to understand the police as a single player. Yet, they are not. The police, in fact, are made up of a multiplicity of players who have their own agency, norms and purposes, who interact with each other and with external players within the state and society. The outcomes of these interactions reflect the policing arena as a constellation of strategies that vary across time and space. What remains constant is the political embeddedness of the police, which is revealed through their continuous encounters with contentious players.

In this chapter, we conceptualize the police as players and protest policing as an arena. We find such a conceptualization useful in grasping the relationship between the state and social movements with respect to the centrality of the police as one of the main actors of the state. Although we keep the discussion primarily on an abstract level, we make use of some empirical illustrations. Along these lines, the chapter has five parts. First, it opens with a brief debate on the goals, means, and constraints that the police face in controlling protest. It continues with an emphasis on the multi-agency nature of the organization where we address the internal dynamics of decision making by the police. Then, the chapter touches upon one of the central themes, policing strategies, distinguishing between conflictual and consensual interactions with protesters, which need not be 
considered as mutually exclusive. This section is followed by a discussion of police cognitive schemes about protesting groups. Finally, we mention the presence of other players that the police interact with while handling protest events.

\section{Police Functions: Goals, Means, and Constraints}

At the moment we are drafting the chapter, protests are occurring in hundreds of cities all over the world. Chanting slogans, marching or dancing on the streets, carrying banners, and maybe performing theatrical scenes, the demonstrators around the globe are being patrolled by the police in (mainly) blue uniforms. Some of them perhaps covered in riot gear, the constables of town X may soon end up in a forceful dispersion of the crowd, taking a few activists under custody, and leaving curious journalists behind in their attempt to collect photographic evidence for the news to be published tomorrow.

Just as protest is a regular mundane practice, albeit for some, so is its policing. Indeed, the police are the primary interlocutors for social movements' conflictual yet generally routinized relationship with the state. Thus, and especially under authoritarian settings, the police serve as a core, if not the only, player to control and suppress multiple manifestations of social opposition and dissent. In that respect, the interactive patterns the police engage with contentious actors in the society are emblematic for the police organization being "inherently and inescapably political because it is at the heart of the state's functioning" (Neocleous, 2000: 117).

Nowadays, the operational terrain that was traditionally monopolized by the public police has been turning into a gateway for a variety of private actors under the label of security and social control (Bayley and Shearing, 1996; Garland, 2001). Although this police-transformation thesis is constantly being challenged (Jones and Newburn, 2002; White and Gill, 2012), some prominent criminologists go as far as to argue that the police "are marginal to the control of crime and the maintenance of order, and always have been" (Reiner, 2010: 19). Underlying this claim is not merely the proliferation of diverse agents within the expanding security sector, but also the broader picture that "[p]ublic peace and security are primarily a function of deeper processes in political economy and culture" (Reiner, 2010: 22). Yet, once we think of the police beyond an amalgamation of men (and women, though to a significantly lesser extent) in blue uniforms, and contemplate it as an institution, it is hard to consider its functions marginal. 
Marxist theorists such as Neocleous, for instance, point to a continuum in policing tasks over centuries, which are - more than the preservation and reproduction - the "fabrication" of social order (Neocleous, 2000). In this perspective, the essential role of the police is not the prevention of crime as such; rather it is concerned with potential threats to the existing social order, particularly materialized in the class-based society. Neocleous also opposes the equation of law enforcement with justice-seeking supposedly carried out by the police since, he maintains, it is not necessarily justice, but order that the police seek to achieve.

These theoretical considerations are useful for imagining the arena in which the police encounter the protesters. What is referred to by both academic circles and the police departments themselves as public "order" policing thus rightfully catches the fundamental task of the police rooted in its modern historical foundations. Far from being a neutral term, securing order implies the state's "interest in suppressing mass dissent that threatens insurrection" which is carried out "under the guise of neutrally enforcing the law and keeping the peace" (Waddington, 1999: 65).

For that matter, the police may resort to a variety of instruments in discharging their duty of handling public protests. Arguably, the first thing that comes to mind is the means of coercion over which the "state" enjoys a monopoly. Thanks to the technological advancements in the arms industry and governments' generosity in allocating resources for security, the depositories of police departments today have turned into a rich arsenal of supposedly less-than-lethal weapons, gas bombs, and pepper sprays which at times cause serious injuries and even deaths, just to remember Carlo Giuliani in Genoa 2001, Alexandros Grigoropoulos in Athens 2008, Ian Tomlison in London 2009, Metin Lokumcu in Hopa (Turkey) 2011, and numerous others.

Nevertheless, coercive means of violence are just one piece in the large repertory with which the police try to control dissident activity. Perhaps they are even marginal. For instance, police departments increasingly utilize surveillance methods as an effective strategy of social control. Closed-circuit television (CCTV) cameras have existed for decades, yet contemporary forms of video surveillance are not confined to stationary devices. The introduction of mobile footage in the hands of policemen or deployed on their vans, drones, and what are called "Sensocopters" markedly enhanced the police's capacity to monitor demonstrations. In Foucauldian terms, surveillance through videotaping is "a situational disciplinary strategy" that is "not only based on the asymmetry of visibility, but also comprises extensive classification, identification as well as 
the occasional direct disciplining of individuals" (Ullrich and Wollinger, 2011: 27).

A technique which is even less transparent and less open to public scrutiny is intelligence. Students of political repression may easily recall the infamous COINTELPRO launched to spot and disrupt "subversive" political activity in the post-World War II United States (Cunningham, 2003). In retrospect, scholars may trace such practices of state infiltration to the political contingencies of the Cold War era. Yet, novel versions of intelligence spread even in the most allegedly democratic and liberal countries of today. Usually, the intelligence branches of the police collaborate with other intelligence agencies of the state, whereby information from different sources is collated, and "categories of suspicion" are created. These categories enshrine "vague characteristics of supposed criminality presented in intelligence reports and officer training, which are then represented as evidence and grounds for detention" (Monaghan and Walby, 2012:12). Especially under the pervasive climate of the War on Terror, "the centralization of intelligence has resulted in a new framework for anti-terror policing where subversive and simply suspicious conduct is lumped under the categories of terrorism and extremism" (Monaghan and Walby, 2011: 146). From a different angle, the intelligence practices can be framed within the broader scheme of counterinsurgency; that is to say, of governments' effort to reclaim legitimacy jeopardized by deepening social opposition (Williams, 2011).

The arena of policing protests is not limited to a solely repressive logic of containing social movement actors and contentious groups. Both the conduct of the police and the right to protest are constrained by a number of rules and regulations. Albeit conflictual in nature, the exercise of public demonstration and assembly also entails a certain degree of cooperation between the police and the organizers of a protest. It is one of the central tasks of the police to communicate, negotiate, and establish dialogue with protest groups before, during, and after the events. As street-level bureaucrats, on a wider scale, they also attempt "to deal with people whose support appears to the police to be weak or non-existent" (Gordon, 1984: 39). This interactive endeavor is commonly referred as "community policing," which is by and large undertaken by "liaison officers." At any rate, the scope and effectiveness of the communication depends on a series of interrelated factors. The prevalent policing "philosophy" in a particular country which may prioritize or else disfavor dialogue with citizens, the history of past conflict with particular groups as well as their willingness to cooperate with the police determine what kind of negotiation, if any, is played out (della Porta, 1998; Winter, 1998). 
In this chapter, we do not make an exhaustive claim that the police do not use any other means in combating social dissent. Whatever additional instruments they utilize, the police enjoy a certain level of discretion on the street. Yet, police behavior is also constrained by a large spectrum of written and unwritten codes of conduct that differ from one country to another. On a legislative level, these are prescribed by laws that regulate police competences and responsibilities on local, regional and state levels, as well as other legal documents such as public order and terrorism acts that encapsulate a wider range of law enforcement agencies including the judiciary. Two things are worth mentioning. First, the police do not always feel obliged to abide by the law; on many occasions they step into the grey zones of the legal sphere. Second, in several old and new democracies there is a recent trend toward empowering the police with greater authority while introducing more stringent regulations on the right to protest.

Besides legal considerations, the police also face troubles emanating from the very performance of their activities on the street. For one thing, these can thwart the police's public legitimacy, yet for another they may risk investigations against their own personnel. What P.A.J. Waddington (1994) labeled as "on-the-job trouble" thus refers to the potential dangers for the lives of protest participants, constables, and bystanders as well as potential damage to property in the course of the event. "In-the-job trouble," on the other hand, can emerge as a consequence of a heavy-handed policing together with allegations of over-enforcement of the law. This may result in judicial and administrative proceedings which are obviously not the most desirable outcome for the policemen. The police are inclined to avoid such troubles, yet in real-life occasions situational and psychological factors may override their conflict-averse inclinations.

\section{Protest Policing as Arenas: Internal Dynamics and Decision Making}

The police are not a single agency, but a multiplicity of players, both horizontally and vertically distributed along the professional axes of the institution. In horizontal terms, police officers specialize in different subjects (homicide, narcotics, organized crime, traffic, public order, etc.) and usually do not interrupt each others' area of specialization. Still, the boundaries between police branches are permeable, and depending on the nature of criminal investigation they frequently exchange expertise and information, sometimes delegating criminal files to a neighboring 
office. Vertically, distinctions between rank-and-file versus senior officers as well as between "gold," "silver," and "bronze" commanders under more paramilitary settings suggests the differentiation of tasks, responsibilities, and professional views within the organization.

Police departments in different nations vary on all these dimensions, from the division of labor between several branches, to the level of autonomy in relation with the competent ministry and provincial authorities, to the centralization versus decentralization of decision-making structures, and to the extent of militarization of the departments. The domain of protest policing is also a blueprint of this organizational diversity (della Porta and Reiter, 1998). For instance, the policing record of the LAPD may differ considerably from that of the NYPD, the same for the contrasts between police departments of, say, Quebec and Toronto, Zurich and Geneva, let alone across countries.

Yet the police share common features in different geographies that reflect the multi-agency of the dynamics of decision making. Imagine a sizeable group of university students in country $\mathrm{Y}$ willing to demonstrate against an increase in educational fees. Prior to the event, they may want to avoid notifying public authorities and the police concerning the spatial and temporal details of the planned protest. Once they start gathering in the urban center, they will most probably come across physically equipped police squads cordoned and prepared for a forceful dispersion. What may escape media and public attention in the meanwhile is a handful of public order officers, most likely in plainclothes, trying to convince group leaders of protesters to disperse by themselves, reminding them of legal provisions and criminal offenses. Of course, this can take an authoritatively patronizing or even threatening fashion rather than being conducted through a facilitative language. Now, further imagine that the bargaining fails and violence erupts between riot squads or "special patrol groups," however you call them, and the protesters.

As usual, the footage of the event is analyzed by video surveillance experts at the central bureau. Suppose they detect a number of individual demonstrators with covered faces throwing missiles at the police. According to legislation in many countries, such acts fall in the cluster of offenses foreseen in anti-terrorism laws. From then onward, the criminal proceedings may engage the terrorism branch within the police department to carry out the investigation. Later on, the arena will shift toward external players such as public prosecutors whereby the control of protest is handed to the workings of the judicial arena.

Of course, this is just a caricaturized illustration of what is at stake in the arena of protest policing where the police interact with the protesters. 
Throughout the whole process, information and orders flow constantly between superior and inferior officers. The next question is; what sort of references do these multiple players have in making decisions in the protest policing arena? Citing Jefferson and Grimshaw (1984), David Waddington (2007: 18) talks about three types of audiences with respect to which chief constables plan on particular policies to be implemented. These are "legal audiences (the courts, police authorities and the Home Secretary); democratic audiences (politicians and the community at large); and occupational audiences (their immediate colleagues of all ranks and the wider police community)." These different audiences may turn into formidable sources of pressure which can hardly be avoided. For example, sometimes the police feel political pressure to "die in a ditch," i.e., show off tough and intolerant policing styles especially when events or persons of symbolic value are protested (Waddington, 1993). After the planning phase, such pressures from the audiences of reference to which the police feel accountable help explain the "on-the-spot decisions made by commanding officers caught up in the heat of public order events" (Waddington, 2007: 20).

From the lowest rank-and-file to the chief constable, individual officers exercise discretion in their decisions. Interestingly, "the police department has the special property ... that within it discretion increases as one moves down the hierarchy" (James Q. Wilson, 1968, quoted in Reiner, 1982: 165). For Reiner, this relative autonomy of the lower ranks "derives from the necessarily dispersed, low visibility natures of his task rather than any failures of organizational control" (Reiner, 1982: 165). In the arena of protest policing the business is, by definition, visible at times wrapping into an urban warfare, and concentrated rather than dispersed. The aforementioned troubles in and on the job also pose negative incentives for lower-rank policemen to rely heavily on their own discretion. Still, the warfare analogy entails a lot of discretion to be given to lower ones in the hierarchy: this was the traditional difference between strategy (of commanders, taken before the battle) and tactics, of those lower down who implemented the strategy during the battle. Particularly in the contexts where public accountability and transparency of police conduct is low, namely where official channels of review and interrogation are not efficient; these negative incentives will surely be not so strong. It is also remarkable that the social science literature has talked of "police riots" to indicate moments in which rankand-file policemen disregard orders, and engage in violent interactions with protestors (Peterson, 2006). 


\section{Interaction with Protest Groups: Cooperation, Conflicts and Dilemmas}

So far, we have provided an overview of the means that the police use in dealing with protest mobilization, and a brief account of the multi-agency of internal decision-making dynamics. The outcome of these two parameters is mirrored in the patterns of interaction with protest groups, which "reflect some more general characteristics of state power" (della Porta, forthcoming). The means available to the police, the constraints on them, and particular decisions implemented accordingly, are all influenced by the political regime.

More than a decade ago, della Porta and Reiter (1998) suggested a framework of protest policing styles which summarized the types of police interaction with protesters along several dimensions (Table 5.1). Arguably, it is possible to open up additional dimensions to further detail the styles of policing in the course of protest events, although the ones presented here still retain their analytical purchase.

Table 5.1 Styles of Policing, or "Interaction"

\begin{tabular}{lll}
\hline Dimension of Interaction & \multicolumn{2}{c}{ Policing Style } \\
\hline Degree of force & Brutal & Soft \\
Number of prohibited behaviors & Repressive & Tolerant \\
Number of repressed groups & Diffuse & Selective \\
Respect for law & Illegal & Legal \\
Timing of intervention & Reactive & Preventive \\
Communication & Confrontational & Consensual \\
Adaptability & Rigid & Flexible \\
Rules of the game & Informal & Formal \\
Preparation & Artisanal & Professional \\
\hline
\end{tabular}

Source: della Porta and Reiter (1998)

The specific styles of policing add up to policing strategies. More or less until the beginning of the 2000s, the two dominant paradigms in describing policing strategies were "escalated force" and "negotiated management." The former designates a strategy that does not tolerate citizens' right to protest and often displays immediate recourse to the excessive use of force, giving precedence to brutal and repressive tactics. The latter, by contrast, is characterized by "a more tolerant approach to community disruption, closer cooperation and communication with the public, a reduced tendency 
to make arrests (particularly as a tactic of first resort), and application of only the minimum force" (Waddington, 2007: 10). The basic argument was that in Western democracies, the dominant paradigm throughout 1960s and 1970 s was escalated force, which gradually began to be replaced by a general acceptance of negotiated management in the 1980 s and $1990 \mathrm{os}$.

Albeit marked by a more dialogical approach by the police, negotiated management embodies a different version of a statist mentality, especially seen from the activists' side. Jarret $\mathrm{S}$. Lovell reminds us of the marginalizing role of the public order management systems (POMS) for groups "working for radical change." The manner in which protest is regulated through negotiation, he claims, is reminiscent of a Foucauldian disciplinary mechanism aimed at pacifying dissent. "For example, the requirement that protesters obtain a permit specifying the time, manner, and location of protest embodies precisely the disciplinary devices of observation, enclosure, and timetables, ... thus providing the State with leverage over protest groups to enact limitations and restrictions on certain forms of political speech" (Lovell, 2009: 114). Protest policing is also selectively applied to different social and political groups: in Italy in the 1980s, while protest by workers tended to be tolerated, the young squatters centers were more often repressed (della Porta, 1998).

The transition to negotiated management has not been a linear process, nor was the experience identical in each and every country. In the UK, for instance, the inner-city riots in the early 1980 s and the miners' strike of 1984-1985 signaled a backlash of tough law-and-order police tactics under the reign of the Thatcher government. The stringent provisions of the 1986 Public Order Act followed suit (McCabe et al., 1988).

But the real challenge came from the policing of the newly emerging social movements, particularly oriented toward the transnational space. Among others, the well-studied global justice movement(s) gave birth to innovative contentious strategies. Social movement scholars unanimously refer to the WTO events in Seattle in 1999 as the milestone for a new era of transnational activism. The strategy of countersummit, in the first place, brought together activists from various nationalities with militant but carnivalesque, disruptive but not necessarily violent tactics that surprised police authorities. For them, the heterogeneous and unpredictable background of the protesters posed a resilient threat in securing public order during these events (della Porta, Peterson, and Reiter, 2006).

As protesters developed new strategies and expanded their action repertoires, national police departments felt obliged to revise their techniques 
of policing. In other words, the police "adapted their strategies to each move by the demonstrators" in an interactive process of diffusion whereby those new strategies are "promoted," "assessed," and "theorized" (della Porta and Tarrow, 2012: 138-142). To be more precise, each encounter with protesters provides the police with firsthand material that contributes to the innovation of new tactics promoted through manuals, trainings, and conferences at national and international levels. Episodes of failure characterized by the police's inability to contain demonstrators peacefully, as was the case in Seattle in 1999 or Gothenburg in 2001 (Wahlström, 2007), are critically assessed for future policing practices. Furthermore, theoretical approaches to policing such as community policing, intelligence-led policing, preemptive policing, and so forth, are also adjusted to the new challenges posed by the changing dynamics of protest. The same holds true for the protesters, too. Concerning countersummits, for instance, activists facing mass deployment of highly equipped anti-riot squads develop tactics such as "social disobedience" (e.g., White Overalls in Italy) whereby they refuse engagement in violence but "wear masks and other instruments - to protect themselves from police weapons - but do not carry any offensive arms" (della Porta and Tarrow, 2012: 134). Such innovations also entail prior meetings and assemblies illustrated by social forums and Internet exchanges, where previous experiences with the police are assessed and new tactics are promoted.

In this regard, ongoing research reveals the resurgence of coercive policing during several episodes of mass demonstrations, transnational protest events in particular. The notorious political rhetoric of the global War on Terror contributed to this more exclusive turn. Scholars started to pinpoint the distinctive properties of police control of transnational mobilization. John A. Noakes and his colleagues (2005) singled out these properties in the following order:

the establishment of extensive no protest zones, often by installing large concrete and metal fence barriers; the disruption of safe spaces, such as convergence centers where protesters would congregate to sleep, eat and acquire information; the use of less-lethal weapons to temporarily incapacitate protesters so police could retake control of spaces of contention; the use of electronic surveillance technology to increase the transparency of spaces of contention and provide real-time information on demonstrators activities to police; pre-emptive arrests to reorganize leaders and large numbers of protesters. (Noakes et al., 2005: 241) 
What they call "strategic incapacitation," in a nutshell, comprises an incremental resort to "surveillance and information sharing, proactive policing, and the elaborate control of space" (Gillham and Noakes, 2007: 350). In fact, strategic incapacitation is not a rupture from previous policing strategies, nor does it mean that they are completely dropped in particular situations. Rather, it selectively aims at "transgressive" demonstrators who are not willing to comply with the police. Nevertheless, the common problem is that despite its selective logic, incapacitation affects not only the targeted participants but all participant, and often the surrounding population as well. Indeed, this translates into the primordial dilemma of protest policing, "how to control members of those crowds who intend to act illegally without alienating members of those that have legitimate aims" (Reicher et al., 2004: 562). On many occasions,

the police respond to early signs of conflict from the crowd - either the presence of certain groups or else actual acts of violence by some crowd members - by clamping down on the crowd as a whole... Hence undifferentiated police constraint can cause groups that were not originally intent to conflict to become more willing to countenance confrontation, to become closer to other more conflictual groupings in the crowd and to become more hostile to the police. (Reicher et al., 2004: 563)

\section{Table 5.2 Protest Policing Strategies}

\begin{tabular}{|c|c|c|c|}
\hline Dimension & Escalated Force & $\begin{array}{l}\text { Negotiated } \\
\text { Management }\end{array}$ & Selective Incapacitation \\
\hline $\begin{array}{l}\text { Toleration of } \\
\text { disruption }\end{array}$ & Low & High & Selective \\
\hline Communication & Low & High & Selective \& one-way \\
\hline Use of arrests & Frequent & Last resort & Selective \& proactive \\
\hline Use of force & High & Last resort & Selective \& less lethal \\
\hline Surveillance & Moderate & Low & Extensive \& real time \\
\hline $\begin{array}{l}\text { Information } \\
\text { sharing }\end{array}$ & Moderate & Low & $\begin{array}{l}\text { Extensive, cross-agencies, } \\
\text { and media-conscious }\end{array}$ \\
\hline Controlling space & $\begin{array}{l}\text { Localized \& } \\
\text { reactive }\end{array}$ & $\begin{array}{l}\text { Localized \& } \\
\text { proactive }\end{array}$ & $\begin{array}{l}\text { Selective, extensive, and } \\
\text { proactive }\end{array}$ \\
\hline
\end{tabular}

Source: Gillham (2011)

Note: The original version designates the strategies in the United States. Thus, the dimension on the First Amendment Rights is dropped here.

Actually, as it is also true for escalated force and negotiated management, strategic incapacitation involves measures that usually extend the scope of 
authority of the police and entail the engagement of additional players from the government and public administration. These measures range from stricter border controls (such as declining activists' entry to the country, temporary lifting of Schengen provisions) to extra-legal regulations or city ordinances that are superimposed on the existing police-driven methods. These recent trends in controlling demonstrations are not confined to the realm of transnational protest. On the contrary, the police employ strategic incapacitation during many domestically rooted outbursts of mobilization which may have received less scholarly attention. Subsequent research should provide more stories on native repercussions of the recent policing trends to enrich our comparativist agenda.

\section{Police Cognitive Schemas about Protesters}

The ways in which police interact with protesting groups are also influenced by their cognitive schemas, which are discernibly cultivated within the police (occupational) culture and subculture. ${ }^{2}$ Classical accounts drew attention to overriding features such as propensity to violence, search for action, conservatism, and lack of tolerance embedded in police behavior. As early as 1960s, Jerome Skolnick singled out the "working personality" of policemen as "shaped by constant exposure to danger and the need to use force and authority to reduce and control threatening situations" (Dempsey and Forst, 2009: 154). As a consequence, it is widely accepted, policemen tend to nurture a "suspicious" attitude toward their environment. That is also why their socialization processes are largely insulated from the rest of society. Later qualitative studies confirmed the propensity among the police to locate themselves at the right of the political spectrum (Baker, 1985).

The predominantly negative portrayal of police cultural traits was challenged on a number of grounds. Critiques, for instance, highlighted the loose usage of the term culture within the literature because it is "rarely embedded in any sort of definition or notion of culture" while "the broader notion of culture is unaddressed or taken for granted" (Crank, 2004: 14).

2 Our usage of the terms police culture and subculture derives separately from their distinction put forward by Crank (2004). Citing a previous work he co-authored with Roy R. Roberg and Jack L. Kuykendall (200o), Crank refers to police culture as a universe of "occupational beliefs and values" adhered by police officers, whereas by police subculture he means the system of values adopted from the society they are part of (2004:30). 
Others point out that cultural analyses of the police fail to recognize "the interpretive and creative aspects of culture" which have to do with "the interaction between the socio-political context of police work and various dimensions of police organizational knowledge" (Chan, 1996). Others indicate the role of "normative orders" such as bureaucratic and legal frames in shaping those attributes (Herbert, 1998). Still others problematize the monolithic descriptions of the police personalities as if they were a homogeneous entity, and underscore sources of variation such as "organizations, rank, and individual officer styles" (Paoline, 2003: 204). The plausibility of these criticisms notwithstanding, most recent statements confirm the endurance of conventional representations of police cultural traits despite transformative attempts in the organization (Loftus, 2010; Skolnick, 2008).

Under these circumstances, it seems hard to imagine that the police strongly empathize with protesters who are particularly contentious, at times disruptive, and militant if radicalized. However, it is just as difficult to assume that the police share the same cognitive attributes regarding different protest groups due to the variation within the personnel across ranks, branches, and location. In that sense, police "knowledge" that refers to police's perception of their own and the external reality, as della Porta and Reiter formulated, looks like a more elaborated conception which is "not limited to fleeting images, stereotypes, and prejudices, but extends to the core problems of protest policing" (della Porta and Reiter, 1998: 23). Beyond cultural dispositions, knowledge joins information and past experiences of the police who, in turn, hold different schemes with regard to protesters. Studies have found a juxtaposition of "good" versus "bad," "genuine" versus "professional," "contained" versus "transgressive" protesters in the eyes of the police. All these different articulations share in common a notion of the legitimacy of protest which becomes undermined as demonstrators lean toward non-compliance, radicalization, and illegal action in content and form. To be more precise, hooligans or groups like "black bloc" are typical examples of the problematic category, whereas more institutionalized activists such as labor unions are perceived less as "troublemakers." On top of everything else, police knowledge tends to vary with the specific individual policeperson careers, training, age, gender, and so on. Police knowledge extends beyond the protesters, to include different actors who - such as the government or public opinion (often identified with the press) - are expected to react to police behaviors, successes, and failures. 


\section{Expanding the Arena: Bringing Other Players In}

While interacting with protesters, the police never act alone. Above all, they are politically influenced by governmental authorities. They are in constant exchange and collaboration with the judiciary. Sometimes military actors step in. Relations with civil society and media also entail frequent communication. Under different regime settings the engagement of these additional players will vary considerably; the arena of protest policing always contains several players so that the police do not remain the only sovereign player in the arena.

To begin with, the control of protests is "calculated" according to a certain logic of political economy. What we observe during protest events, e.g. deployment of personnel, equipment and vehicles, construction of fences, cameras and so forth, requires serious budgetary allocations, especially when it comes to big transnational events:

Some of this money is spent on overtime salaries, extra personnel (including private police), city services such as transportation and waste management, and federal services, such as special deployments of military and border agencies. Some of the money is invested in new technologies, which are left behind with local police agencies long after the event. This arsenal of new technologies and weapons includes new surveillance technologies, ... "less-than-lethal" weapons, ... and the latest riot gear. (Starr, Fernandez, and Scholl, 2011: 49)

Here, what is at stake is a political question with the police at the very center of it. The expenditures allotted to the control of protest shed light on the contemporary orientations of governance that is very much marked by the fetish of security. To illustrate, for securing the G8 summit in Heiligendamm in 2007 from "dangerous" protesters, it has been noted that " $\mathrm{t}]$ he money

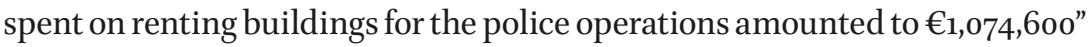
(Starr, Fernandez, and Scholl, 2011: 53). Likewise, the costs for the G8 and G20 meetings in Toronto in 2010 totaled $\$ 929$ million, of which $\$ 507$ million were spent by the Royal Canadian Military Police (RCMP). This money was spent to safeguard political leaders from the "threat" posed by the protesters. Actually, these examples suggest that the political economy of dissent control stipulates excessive policing strategies that are not decided upon merely by the police themselves. There is a political story, backed by political players.

A similar process of extra-police player involvement is seen in the spatial dynamics of protest policing. "Physical control of space," Luis Fernandez 
argues, "refers to ways in which police departments carefully select and map out the material environment before and during a protest" (Fernandez, 2008: 93). These may also include determining the marching routes and assembly places in the urban centers, or imposing stricter border controls as we have mentioned before. The point is that the police do not take decisions in isolation, but rely on a set of external actors during the planning of the events. A commanding officer in Washington, DC, aptly summarizes the point:

Every city agency has a part in it, whether it's the Department of Public Works for removal of things that could be used as projectiles, through the Department of Transportation to help us with the control of traffic in the outskirts of one of these things; through the fire department who may provide for medical services for protestors and police officers; all the way up to include the federal government, the FBI and all sorts of intelligence networks. (Fernandez, 2008: 96)

The police also develop tight relations with the military as a player. Presumably, in authoritarian contexts, or where the capabilities of the police are relatively weak due to a low level of professionalization, resource allocation, and so on, military assistance of the police should be a more widespread phenomenon. But the question is valid for democracies as well, where a non-military police developed. Previously, military aid to the police during tough public order incidents was more frequent and broadly accepted (Johansen, 2005; Palmer, 1988). The police in many established democracies have been investing in their own specially trained, highly equipped (para) military units such as special weapons and tactics (SWAT) teams in the United States. Some authors are alarmed by the explosion and overuse of such units, considered as disproportionate to the violent crime rates in comparison with the past (Fisher, 2010). Thus, the deployment of the military is generally considered as a last resort in worst-case scenarios, and "when it is done," as Alice Hills (1995: 454) states about the UK, "as in the 1926 general strike, they operate at the request of the police, in support of the police, and under the general authority of the police." Where the police are operationally subject to the authority of the military, by contrast, the relationship is the other way around.

In addition, the police may request the assistance of traditionally rooted military forces like the gendarmerie. Albeit military in structure, such as Guardia Civil in Spain or Gendarmerie Nationale in France, these forces undertake policing tasks in rural areas, and are supervised by both civilian 
and military authorities. At times, the deployment of the gendarmerie may generate controversial situations that challenge common sense perceptions on the issue. Regarding the Argentinean state's repression of the piqueteros, as recently documented, the gendarmerie, "respectful of protesters' rights and reticent to use lethal force, clashed with the 'popular image' ... as fierce, unfeeling 'Robocops,' who enjoy violently 'repressing' the population and who are analogous in many ways to the dirty warriors" (Carlson, 2006: 183). At any rate, despite growing tendencies toward paramilitarization, the military's entry into public disorder situations is definitely not an outdated question even in the well established democracies of the present.

While with the development of the nation-state came a process of nationalization of the police, globalization - and the transnational protests it brings about - has seen the development of complex arrangements, with often police from different countries intervening in the control of the same events. As Reiter and Fillieule (2006) observed, these developments were not followed by a transnational protection of the rights to protest that have been more and more often (and allegedly arbitrarily) restricted.

Finally, public police interact with private police with increasingly permeable borders between the two. Authoritarian regimes, in particular, rely on the additional support of militias and voluntary citizen forces to control public dissent. For instance, the party militia in the GDR were called in by the government to repress the 1989 civil right movement (but refused to go). In Mubarak's Egypt, the regime used to hire groups of gangs known as baltajiya to suppress protesters, most recently during the mass meetings on Tahrir Square. A further example is the basij in Iran which has been active since their establishment by Khomeini's order in 1979. Even in democracies, the semi-privatization of spaces (such as malls or airports) has increased the role of privately engaged police in the control of protest.

\section{Conclusion}

This chapter has aimed at understanding the police as players and protest policing as an arena. Without focusing on a particular case, we have discussed the topic at a relatively abstract level along several dimensions. The central idea was that the police are made up of multiple players who interact both among each other and with various players external to the police to shape the dynamics of protest policing. These dynamics are enshrined in the means used, the decisions taken, strategies adopted, as well as the cognitive 
schemas developed, all of which are played out through interactions with the protesters.

Police departments today enjoy rich repositories of policing instruments that vary from supposedly less-than-lethal weapons to real-time surveillance and from several sources of intelligence to communicative skills. In making use of these means the police rely on a certain level of discretion, yet they are also constrained by a set of written and unwritten rules, potential troubles in and on the job, and the pressures from different audiences to whom they are (or feel they are) accountable. These multiple layers intermingle with the cultural dispositions of the police deriving from their occupational orientations. Traditionally, the police are associated with exposure to danger and a tendency to use force, producing a particularly suspicious attitude toward their environment. More specifically, however, it is their "knowledge" that they accumulate through education, training, and past experiences that shapes their different perceptions of protesters. Overall, protest policing strategies are filtered through these dimensions that vary across time and space. Many scholars observe a backlash of authoritarian methods that dominate those strategies in a neoliberal age. Still, the recent rise of strategic incapacitation does not preclude previous paradigms of escalated force and negotiated management as they are variably implemented on different national and transnational arenas of policing. The ultimate point is that whatever strategies are employed, the police never act alone in those arenas as they are backed as well as challenged by other political and bureaucratic players of the state.

We consider this is a useful conceptual framework for grasping broader processes of the relationship between the state and social movements. Indeed, the centrality of the police not only lies in its being one of the founding institutions of the state, but also in the fact that protest policing is a mundane practice just as protest is. The conceptualization of this phenomenon through players and arenas should yield a fertile analytical ground for empirical research on different cases of political geographies around the world.

\section{References}

Baker, Mark. 1985. Cops: Their Lives in Their Own Words. New York: Fawcett.

Bayley, David H., and Clifford D. Shearing. 1996. "The Future of Policing." Law \& Society Review 30: 585-6o6.

Carlson, Eric Stener. 2006. “The Gendarmerie's Response to Social Protest in Argentina.” In Edward Epstein and David Pion-Berlin, eds., Broken Promises? The Argentine Crisis and Argentine Democracy. Lanham, MD: Lexington Books. 
Chan, Janet. 1996. “Changing Police Culture." British Journal of Criminology 36: 109-134.

Crank, John P. 2004. Understanding Police Culture. Cincinnati, OH: Anderson.

Cunningham, David. 2003. "State versus Social Movement: FBI Counterintelligence against the New Left." In Jack Goldstone, ed., States, Parties, and Social Movements. Cambridge: Cambridge University Press.

della Porta, Donatella. 1998. "Police Knowledge and Protest Policing: Some Reflections on the Italian Case." In Donatella della Porta and Herbert Reiter, eds., Policing Protest: The Control of Mass Demonstrations in Western Democracies. Minneapolis: University of Minnesota Press.

della Porta, Donatella, Abby Peterson, and Herbert Reiter. 2006. "Policing Transnational Protest: An Introduction.” In Donatella della Porta, Abby Peterson, and Herbert Reiter, eds., The Policing of Transnational Protest. Aldershot: Ashgate.

della Porta, Donatella, and Herbert Reiter. 1998. "Introduction: The Policing of Protest in Western Democracies." In Donatella della Porta and Herbert Reiter, eds., Policing Protest: The Control ofMass Demonstrations in Western Democracies. Minneapolis: University of Minnesota Press.

della Porta, Donatella, and Sidney Tarrow. 2012. "Interactive Diffusion The Coevolution of Police and Protest Behavior with an Application to Transnational Contention." Comparative Political Studies 45: 119-152.

Dempsey, John S., and Linda S. Forst. 2009. An Introduction to Policing. New York: Cengage Learning.

Fernandez, Luis A. 2008. Policing Dissent: Social Control and the Anti-Globalization Movement. New Brunswick, NJ: Rutgers University Press.

Fisher, A. James. 2010. SWAT Madness and the Militarization of the American Police: A National Dilemma. Santa Barbara, CA: Praeger.

Garland, David. 2001. The Culture of Control: Crime and Social Order in Contemporary Society. Oxford; New York: Oxford University Press.

Gillham, Patrick F. 2011. "Securitizing America: Strategic Incapacitation and the Policing of Protest Since the 11 September 2001 Terrorist Attacks." Sociology Compass 5: 636-652.

Gillham, Patrick F., and John A. Noakes. 2007. "'More Than a March in a Circle': Transgressive Protests and the Limits of Negotiated Management." Mobilization 12: 341-357.

Gordon, Paul. 1984. "Community Policing: Towards the Local Police State?" Critical Social Policy 4: $39-58$.

Herbert, Steve. 1998. "Police Subculture Reconsidered." Criminology 36: 343-370.

Hills, Alice. 1995. "Militant Tendencies-Paramilitarism in the British Police." British Journal of Criminology 35: 450-458.

Johansen, Anja. 2005. Soldiers as Police: The French and Prussian Armies and the Policing of Popular Protest, 1889-1914. Aldershot: Ashgate.

Jones, Trevor, and Tim Newburn. 2002. "The Transformation of Policing? Understanding Current Trends in Policing Systems." British Journal of Criminology 42: 129-146.

Loftus, Bethan. 2010. "Police Occupational Culture: Classic Themes, Altered Times." Policing \& Society $20: 1-20$.

Lovell, Jarret S. 2009. Crimes of Dissent: Civil Disobedience, Criminal Justice, and the Politics of Conscience. New York: New York University Press.

McCabe, Sarah, Peter Wallington, John Alderson, Larry Gostin, and Christopher Mason. 1988. The Police, Public Order and Civil Liberties: Legacies of the Miners'Strike. London: Routledge.

Monaghan, Jeffrey, and Kevin Walby. 2011. "Making up 'Terror Identities': Security Intelligence, Canada's Integrated Threat Assessment Centre and Social Movement Suppression." Policing \& Society 22: 133-151. 
-. 2012. "'They Attacked the City': Security Intelligence, the Sociology of Protest Policing and the Anarchist Threat at the 2010 Toronto G2o Summit." Current Sociology 6o: 653-671.

Neocleous, Mark. 200o. The Fabrication of Social Order: A Critical Theory of Police Power. Sterling, VA: Pluto Press.

Noakes, John A., Brian V. Klocke, and Patrick F. Gillham. 2005. "Whose Streets? Police and Protester Struggles over Space in Washington, DC, 29-30 September 2001." Policing \& Society 15: 235-254.

Palmer, Stanley H. 1988. Police and Protest in England and Ireland, 1780-1850. New York: Cambridge University Press.

Paoline, Eugene A., III. 2003. “Taking Stock: Toward a Richer Understanding of Police Culture.” Journal of Criminal Justice 31: 199-214.

Peterson, Abby. 2006. "Policing Contentious Politics at Transnational Summits: Darth Vader or Keystone Cops?” In Donatella della Porta, Abby Peterson, and Herbert Reiter eds., The Policing of Transnational Protest. Aldershot: Ashgate.

Reicher, Stephen, Clifford Stott, Patrick Cronin, and Otto Adang. 2004. "An Integrated Approach to Crowd Psychology and Public Order Policing." Policing: An International Journal of Police Strategies \& Management 27: 558-572.

Reiner, Robert. 1982. "Who Are the Police?" The Political Quarterly 53: 165-180.

-. 2010. The Politics of the Police. Oxford: Oxford University Press.

Reiter, Herbert, and Olivier Fillieule. 2006. "Formalizing the Informal: The EU Approach to Transnational Protest Policing." In Donatella della Porta, Abby Peterson, and Herbert Reiter eds., The Policing of Transnational Protest. Aldershot: Ashgate.

Skolnick, Jerome H. 2008. "Enduring Issues of Police Culture and Demographics." Policing \& Society 18: $35-45$.

Starr, Amory, Luis Fernandez, and Christian Scholl. 2011. Shutting Down the Streets: Political Violence and Social Control in the Global Era. New York: New York University Press.

Ullrich, Peter, and Gina Rosa Wollinger. 2011. "A Surveillance Studies Perspective on Protest Policing: The Case of Video Surveillance of Demonstrations in Germany." Interface 3: 12-38.

Waddington, David P. 2007. Policing Public Disorder: Theory and Practice. Devon: Willan Publishing.

Waddington, P. A. J. 1993. "Dying in a Ditch: The Use of Police Powers in Public Order." International Journal of the Sociology of Law 21: 335-353.

-. 1994. Liberty and Order: Public Order Policing in a Capital City. London: UCL Press.

—.1999. Policing Citizens: Authority And Rights. London: UCL Press.

Wahlström, M. 2007. "Forestalling Violence: Police Knowledge of Interaction with Political Activists." Mobilization 12: 389-402.

White, Adam, and Martin Gill. 2012. "The Transformation of Policing from Ratios to Rationalities." British Journal of Criminology 53: 74-93.

Williams, Kristian. 2011. "The Other Side of the COIN: Counter-insurgency and Community Policing." Interface 3: 81-117.

Winter, Martin. 1998. "Police Philosophy and Protest Policing in the Federal Republic of Germany, 1960-199o." In Donatella della Porta and Herbert Reiter, eds., Policing Protest: The Control of Mass Demonstrations in Western Democracies. Minneapolis: University of Minnesota Press. 


\title{
6 The Military
}

The Mutual Determination of Strategy in Ireland, 1912-1921

\author{
Ian Roxborough
}

This chapter examines an extreme case of protest: the armed struggle of Irish nationalists between 1912 and 1921, and the efforts on the part of sections of the British state to defeat the rebellion by the use of armed force. It examines the different cognitive frames and strategies of the various police and military organizations of the British state (Royal Irish Constabulary, Dublin Metropolitan Police, the "Black and Tans" and Auxiliaries, and the British Army, together with the intelligence services) as they confronted armed insurgency in Ireland. States, as Jasper (2015) and Goldstone (2004) have argued, should not be treated as unitary actors. This is immediately apparent in the case of the British state in Ireland, where even the sectors where one might expect considerable policy coherence - in the coercive organizations and in the Cabinet - displayed a high level of organizational incoherence and difficulty in coordinating strategy. This was one factor, perhaps a crucial one, in the failure of British counterinsurgency in Ireland.

The Anglo-Irish coercive players were far from homogeneous, and approached the struggle with distinct worldviews, frames, or mental maps to guide them in their search for appropriate policies. These maps were not simply cognitive, but also deeply emotional and value-symbolic, mobilizing affective solidarities. Since the interests and organizational cultures of the various players were distinct - and often at odds with each other - the tensions between them must be understood if we are to understand how "the state" developed its response to insurgency. We can arrive at a more accurate analysis of state response by abandoning any notion that we are dealing with a unified actor, much less a unified and coherent rational actor.

The conflict in Ireland was multi-dimensional: it was not simply a struggle for national independence against a recalcitrant empire. It was also a sectarian struggle between Catholics and Protestants in Ireland. There was thus a triangular conflict between the largely Catholic southern Irish nationalists, the Protestant Ulster loyalists, and the British government, itself deeply divided over what policy to adopt. Ulster acted as a "spoiler," preventing the introduction of Home Rule in 1914, and 
preventing the creation of a united and independent Ireland. Much of the historiography of the period focuses on southern (and largely Catholic) nationalism and the conflict with the coercive organizations of the British state. Ulster saw its share of violence, though this took a different form, that of sectarian conflict between Protestants and Catholics. The importance of Ulster, however, lay not in direct conflict but in its role of spoiler, precluding any easy accommodation of Irish nationalist aspirations. The very existence of Ulster was a factor in the calculations of all players. Ulster - with the specter of a large and uncontrollable Protestant militia and the potential of a sectarian, civil war throughout Ireland - was the dog that didn't bark.

This chapter highlights three key dynamics: (1) each party to the conflict - the British government, the Southern nationalists, and the Ulster loyalists - was a congeries of organizations, movements, and powerful individuals. There was little organizational coherence, and principal-agent problems abounded, as leaders proved unable to control their rank-and-file or their allies. (2) Not only were the actors not unitary, they were not entirely "rational," either: the frames they used to understand events were inaccurate schemata, and/or there was muddled thinking. (3) All actors in this conflict shaped their strategies, at least in part, in response to their understandings (accurate or otherwise) of what their adversaries (and potential allies) were doing. The repertoires of contention and the strategies and tactics adopted shifted rapidly in a series of moves and countermoves. Much social action and outcomes is contingent, for all sorts of reasons. In this case, a major source of contingency stemmed from the fact that actors were not, in any simple sense, "rational," and frequently misunderstood the motives and intentions of other players. In what follows I will demonstrate how these three issues - fragmentary actors, the absence of clearly rational strategies, and strategic interaction - together offer a set of analytic tools with which to understand this conflict. I follow a narrative organization, highlighting the analytic issues as I proceed.

\section{Background}

The struggle for Irish independence has a long history. This chapter focuses only on the armed conflict between 1912 and 1921 and its immediate antecedents. Following the Act of Union, Ireland became, in 1801, an integral part of the United Kingdom with its own MPs sitting in Westminster. For the next century, Ireland would remain the poorest, most rural part 
of a multinational polity. Violent agrarian conflict was endemic, and a culture of organized resistance developed that pitted poor and insecure tenant farmers against large landowners, often of English extraction. The formal exclusion of Catholics from political power, from the professions, and from the universities - a result of earlier British dynastic and religious struggles - added a religious, and national dimension to the agrarian protest. By the late nineteenth century, these grievances had been largely resolved and Ireland was experiencing sustained economic growth, but a pernicious legacy of bitter feelings toward England and the English remained.

Policing was carried out by two separate bodies. In the capital, the Dublin Metropolitan Police was modeled after the Metropolitan Police of London. An unarmed body of constables and detectives, it was oriented toward routine crime prevention and detection. A small special branch kept track of political subversives. In the rest of Ireland, an armed constabulary, the Royal Irish Constabulary (RIC), much along the lines of the Italian Carabinieri or the French Gendarmerie, was equipped with rifles and was organized as a national, rather than a local force. Constables were housed in police barracks, usually in groups of eight to ten men, and could be assigned anywhere in the country. That said, the paramilitary aspects of the RIC at this time should not be exaggerated.

The end of the nineteenth century saw a flowering of cultural nationalism (the Gaelic revival) in Ireland, and it was this - and not agrarian discontent or confessional exclusion - that fed the nationalist movement that now emerged. There was a deliberate and self-conscious effort to "recover" a sense of Irishness. Classes in Gaelic were held, and Irish sports, including hurling, were popularized.

These efforts politicized many spheres of daily life. The result was that "Irishness was to be redefined and, with it, the shape of the Irish nation" (Townshend, 2005: 8). Like most European nationalisms of this time, the new Irish cultural nationalism emphasized the unity of the "people" with the soil in a romantic, nostalgic, and organicist image of the virtues of the simple rural life contrasted with the cosmopolitanism of high urbanism.

The Gaelic revival melded with an implicit (and sometimes explicit) assertion that Ireland was a nation defined by its adherence to Catholicism. This was partly in response to a sense that the oppressors were English Protestants, and that one of the distinctive features, therefore, of Irish nationhood was a widespread Catholic piety. This new definition of "Irishness" in terms of Catholicism and Gaelic culture was to prove an insuperable obstacle to the creation of an Ireland that was both united and free of British 
rule. The fact that 29 percent of the population of Ireland were Protestants, and that most of these were concentrated in the province of Ulster (thereby giving them great political clout) posed a central difficulty for this line of thought. Nationalists could have a united Ireland or a Catholic Ireland, but not both.

By the end of the nineteenth century, Irish nationalists could draw on two distinct traditions of protest, with radically divergent strategies. On the one hand there was the Fenian tradition of conspiracy, terrorism, and insurrection. On the other hand there was a largely successful effort to use Irish representation in Parliament to advance the cause of independence by pressing for "Home Rule" legislation.

\section{Opening Moves: Home Rule and Ulster Opposition}

In 1912 the Gladstone ministry introduced the Third Home Rule Bill, which, unlike the preceding attempts, was not vetoed by the House of Lords. It was intended to come into effect in 1914. Irish independence appeared to be about to be advanced peacefully, and Ireland would be left to run its internal affairs.

Trouble began when the vast majority of Ulster Protestants simply refused to accept Home Rule. Half a million signed the Solemn League and Covenant in September 1912, the very title redolent with Protestant symbolism. In January 1913, an armed militia, the Ulster Volunteer Force, was formed and grew quickly to about 100,000 members. The Catholic nationalists in the south responded by creating their own militia, the Irish Volunteers. Both sides began to import weapons. In April 1914 the UVF ran nearly 50,000 rifles and three million rounds of ammunition into Ulster. The Liberal government dithered over what to do. British efforts to stem the flow of arms were ineffectual.

In August 1914, there were over a quarter of a million men enrolled in citizen militias in Ireland. A substantial minority of them were armed with modern weapons, and more of these were on their way. Ireland had entered a confused and volatile state that was not yet civil war, but no longer peace. (Townshend, 2005: 28)

Thus the conflict in Ireland, at its core a struggle over national identity and national independence, was transformed into a sectarian or confessional division. Mainstream Irish nationalism had identified itself as Gaelic and Catholic, and was thus in no position to transcend the sectarian divide by 
offering a vision of Irishness that delinked national identity and religious affiliation. Ulster Protestants elected to maintain their Protestant identity by reaffirming their ties with Britain, destroying the possibility of a peaceful, constitutional solution to Irish aspirations for independence. In the words of historian Charles Townshend, "'Ulster' had opted out of Home Rule, and had threatened armed rebellion to do so. It was this armed threat that transformed and militarized the language of Irish politics as the Home Rule crisis unfolded" (Townshend, 2005: 30).

The British Cabinet contemplated enforcing Home Rule over Ulster opposition. This was politically risky: the Liberal Party was split internally over the Home Rule issue, and some Conservative political leaders were openly advocating armed resistance to Home Rule. What tipped the scale was the determined resistance of sections of the British officer corps, many of whom identified with Protestant loyalism. A major crisis in civil-military relations ensued. The commander of the Curragh base, Sir Henry Paget, was ordered by the War Office to begin preparations to put down the Protestant resistance. Fifty-seven of the seventy officers in the camp made it known that they were unwilling to take part in any action against the Protestant community of Northern Ireland. A series of meetings between army officers and the Cabinet led to the issue being brushed under the carpet (Beckett, 1986). British civil-military relations had deteriorated to the point where the civilian political leaders could no longer count on the military to carry out their wishes.

Unsure of the reliability of its own military forces, and in any case reluctant to repress its loyalist supporters, the British government backed down and the Ulster Protestants were allowed to continue to arm themselves. Here was an instance of a radical flank setting policy.

Before the Ulster crisis could find a political settlement, the First World War erupted. The Home Rule bill received royal assent in September 1914, but its implementation was suspended until the end of the war, forcing Irish nationalists into a variant of what Jasper terms the "naughty or nice dilemma" (Jasper, 2006: 106-107). The Parliamentarians, led by John Redmond, sought to use the war as an opportunity to demonstrate their loyalty to the Crown, hoping thereby to reap the reward of Home Rule once the conflict was over. Thousands of Irishmen flocked to the colors. Other nationalists, drawing on the old Fenian tradition, hewed to the slogan that "England's difficulty is Ireland's opportunity." As the war dragged on, and as its costs rose, the Fenian choice was to prove the winning formula.

The outbreak of war did, for a while, lead to an uneasy quiet in Ireland. Initially it increased pro-British sentiment as many Irishmen volunteered to 
serve in the British Army. However, by 1916 the tradition of conspiracy and urban insurrection had been resuscitated. On Easter Monday, 1916, between 1,200 and 1,600 armed troops of the Irish Republican Army (IRA) and the militia of the organized labor movement, the Citizens' Army, took over the center of Dublin, to the surprise and curiosity of the local population. A republic was proclaimed.

\section{Easter 1916: Catholic Martyrdom}

A conspiratorial group within the Irish Republican Army, the Irish Republican Brotherhood (IRB), had planned an uprising throughout Ireland for Easter Sunday, 1916. Preparations were made in as much secrecy as possible. The cover for assembling bodies of armed men was to be a field exercise of the Irish Volunteers. As word of what was planned leaked out, divisions within the IRB rose to the surface. The moderate elements within the IRB sought to cancel the insurrection. This resulted in a postponement from the Sunday to the Monday and much confusion about what actually was to take place. In the event, the insurrection went ahead on the Monday. A Republic was proclaimed, and the insurgents settled down to await an uprising in the rest of Ireland and promised German assistance. Neither was forthcoming.

The British Army swiftly brought in reinforcements, sealing off the center of Dublin. They then moved onto the attack and, in several days of intense street fighting, forced the surviving rebels to surrender. The insurrectionaries had underestimated the earnestness and strength of the British response, and overestimated the level of support from the general population in Dublin and from rebels elsewhere in Ireland.

In its revolutionary technique, the uprising was a revival of a nineteenthcentury European tradition of street fighting. In its symbolism, the movement was dominated by the Catholic Martyrdom of its leaders, most notably Patrick Pearse. This was new, part of the Gaelic revival.

In terms of an instrumental assault aimed at the seizure of state power, the rising was an unqualified failure. However, it set off a train of events that eventually led to a successful insurgency against British rule. The Rising, as it came to be known, drew on romantic notions of nationalist struggle and on Catholic notions of sacrifice and martyrdom. It inspired a generation of nationalist radicals, legitimizing the use of mass violence, branding the British state more firmly than ever as an imperialist oppressor.

The leaders of the Rising, such as Patrick Pearse, were strong believers in the potency of symbolic politics. Dramatic acts had the power to 
galvanize public opinion. Charles Townshend notes that "[a]s he moved into middle age, his 'imagery showed an almost pathological lust for violence'" (Townshend, 2005: 23). The redemptive violence of revolution was married to a Catholic pursuit of martyrdom. Such men "saw time as their enemy, not their ally... This would be their only chance to fulfill the IRB's dream of revolution - an opportunity elevated into a spiritual necessity by Pearse and others, who believed that Ireland's soul could be saved only by an act of Christ-like sacrifice" (Hart, 2005: 78-79).

As the various players monitored the actions and strategies of the others, there was much room for misperception. In the case of the Easter Rising, the British authorities in Ireland, both civil and military, were caught unprepared. British intelligence in Ireland during the First World War was focused entirely on the threat of German spies, German subversion, and the possibility of a German invasion of Ireland. As a result, although tipped off about IRB plans for an uprising on Easter Sunday, British authorities in Dublin made no preparations to deal with it.

Sixteen of the leaders of the Rising were shot by firing squad. The public response caught the British authorities off guard: in the midst of a great war the execution of a handful of armed rebels seemed eminently justifiable. The Irish public, however, was outraged, and these men were seen as martyrs for the cause of Irish independence.

Another mistake was made in the battle to define the nature of the conflict. In the aftermath of the Rising, more than 3,00o suspects would pass through army custody. Most prisoners were sent to a vacant camp for German prisoners of war in Frongoch, North Wales. Here they were mostly left to themselves in the sort of regime that prisoners of war would experience. The more politically active among the prisoners organized the inmates and began a campaign of resistance to the British camp authorities. The less political prisoners were inducted into the nationalist cause, and Frongoch became the university of the revolution. A new generation of leaders and activists came to the fore: more pragmatic than the Easter martyrs, but equally willing - in their own way - to utilize martyrdom for their purposes. This would enable a shift in strategy from open insurrectional confrontation to guerrilla warfare. "Sinn Fein got the benefit of the Rising, whereas the Irish Volunteers and the IRB - the Rising's vehicles - had been decapitated and dismembered by casualties and executions" (Hart, 2005: 136).

Meanwhile, the Great War continued. In Britain the government had initially relied on a volunteer army. By 1916 it came reluctantly to the decision to introduce conscription, but exempted Ireland in order not to create more problems for itself. Following the German offensive of March 1918, the 
British government sought to impose more thoroughgoing conscription in England, Wales, and Scotland. The price it paid to do this was to remove the exemption Ireland had hitherto enjoyed. Irish nationalists vowed to resist any effort to implement conscription in Ireland. In fact, the British government had no serious intention of doing so, and quickly backed down in the face of mass protest (Gregory, 2002). However, considerable damage had been done. The leading nationalist organization, Sinn Féin, capitalized on the anxieties generated by the threat of conscription to rapidly expand its membership (Hart, 2005: 171-172).

The result was a rapid re-alignment of the Irish party system. The first post-war elections, in 1918, were the death knell of the old Parliamentary Party. They were swept aside by the new radical nationalists of Sinn Féin. It was time for a new strategy.

\section{Sinn Féin Strategy}

Sinn Féin's broad strategy was to problematize the obedience given to, and acquiescence in, British rule. This could be achieved in a variety of ways. Campaigns of non-cooperation and boycotts were envisaged. Ostracism and intimidation of "collaborators" with British rule would play a part. If armed conflict were to occur, it would not take the form of a sudden urban uprising led by a secret organization, along the lines of Easter 1916, but would be guerrilla warfare.

Elections would no longer be utilized to produce a bloc in the British Parliament which could negotiate for better treatment for Ireland, but would instead serve as a referendum to demonstrate popular support for Sinn Féin. They would legitimate an assertion of sovereignty. In January 1919 an Irish parliament (Dáil Éireann) was called into being and a republic was declared (again.)

A central part of any revolutionary struggle, indeed in Charles Tilly's view the very definition of a revolutionary situation, is the effort to establish a counterstate of some kind that can directly compete with the "official" state for legitimacy and allegiance (Tilly, 1978). Remarkably, the British government seemed quite obtuse about this danger. They allowed the creation of Irish parliamentary institutions and they would shortly permit the administration of justice to collapse in rural and village Ireland.

On 21 January [1919], Dail Eireann, made up of those Sinn Fein MPs not in jail, met for the first time, in the Dublin Mansion House. A Declaration of Independence was issued, and a government was formed to carry out 
Sinn Fein's election pledges. While the occasion was public and watched by policemen, it was ignored by the British government as just so much hot air. This republic was indeed imaginary - as was its ability to govern - but those concerned were very serious about making it a reality. (Hart, 2005: 187)

\section{IRA Strategy}

The Irish Republican Army, secretly dominated by the IRB, was the armed wing of Sinn Féin. The IRA was to implement the military component of the strategy of making Ireland ungovernable.

The first sustained IRA campaign was against the police. The Royal Irish Constabulary was a national police force, widely scattered in the towns and villages of Ireland. Unmarried officers - the majority of the force - were housed in small "barracks," usually row houses indistinguishable from any other. The first step was to ostracize and harass police officers. This was followed by attacks on poorly defended barracks with the aim of seizing weapons and increasing pressure on the RIC to abandon rural and small town Ireland. Attacks grew in size and frequency in the second half of 1919, and then rapidly escalated. It became perilous to maintain a continuous police presence in the countryside. Police barracks, usually physically vulnerable or only hastily fortified, came under attack and were often abandoned. The IRA burned evacuated barracks: this sent a clear symbolic message to the local population. In practical terms, police presence in many parts of rural Ireland became episodic and ineffectual. The British court system was paralyzed by the unwillingness of juries to convict or of witnesses to testify against the IRA. RIC morale plummeted and resignations soared. Many constables came to a modus vivendi with their nationalist opponents, opting for passivity in order to survive through this time of troubles and live to enjoy their pensions. The Dublin Metropolitan Police, whose detective force was hit hard by IRA assassins, lapsed into political passivity. By intimidating and killing the police, and by preventing the operation of the Crown courts, the administration of justice in the countryside and small towns was stopped. It was replaced by the establishment of a shadow state with its own Dáil Courts and Sinn Féin police.

In their moral framing Sinn Féin and the IRA reached back to the themes of martyrdom which had been so prominent in 1916, but now subordinated them to a more disciplined political organization. A new tactic was introduced: arrested militants now went on hunger strike (a tactic copied directly from the British suffragettes), and large crowds gathered outside jails to protest and lament. This placed the British authorities on the horns of an 
unattractive dilemma: allowing the hunger strikers to die would paint the state as cruel and barbaric; releasing them would be a show of weakness. Funerals for IRA martyrs were incorporated into these prolonged mass rituals of solidarity and defiance.

Imprisonment was part of a larger set of symbolic and emotional rituals that bolstered rebel resolve.

Prison was one of the vital transformative experiences that made clerks and farmers' sons into new men: soldiers and martyrs. The revolution had to be imagined before it could be enacted, and the revolutionaries had to imagine themselves into history to give themselves the power to change it. To stand in the dock and defy the Crown, to be cast into prison for being a patriot - these were clichéd but immensely powerful roles, endlessly rehearsed in nationalist songs, histories and literature. By re-enacting them you could become your heroes. What seemed immature or naïve to observers at the time, or to skeptical historians since, could have the force of a religious conversion to the people who were living it... Playing the role of the defiant rebel was far more than mere theatricality. It was a source of power and energy and solidarity - part of the basic chemistry of revolution. (Hart, 2005: 168)

The Cabinet wavered. Its initial response was to release the hunger strikers. This did nothing to quiet nationalist protest; and so the Cabinet shifted to a hard line. In October 1920, alarmed that his release might lead to a mutiny of police and army, the Cabinet allowed a Cork Sinn Féin leader, Terence MacSwiney, to die. The Cabinet's decision worked: the IRA stopped using the tactic of hunger strikes.

\section{The British Response}

The British Army responded by demanding the implementation of martial law and summary military courts which would operate with different rules of evidence. This was resisted by the politicians, who held the view that defeating the insurgents was "a police matter." But the RIC were in disarray and the army - with vastly expanded imperial commitments after the First World War and facing massive industrial unrest in Britain - had few men to spare for Ireland. This shortfall in manpower was met by efforts to augment the Irish police. In March 1920 the British recruited recently demobilized veterans of the First World War, into two new formations: the notorious Black and Tans and the Auxiliaries. (The Black and Tans were formed from 
ex-soldiers; the Auxiliary Division, from ex-officers.) These men, who treated all Irish as alien enemies, rapidly acquired a well-deserved reputation for indiscriminate violence. It marked a new strategy on the part of one section of the British state: a "police war" of counterterror and reprisal.

The Black and Tans and the Auxiliaries were virtually independent of both the police and the army.

[W] hat they were actually to do, no-one said. Here, then, was a force of immense potential, brought into action with the minimum of planning... [I]t was left to work out its own salvation in conditions where experience of the Great War was of limited relevance... It lacked the military discipline essential to an armed force under constant stress... Some became first-class fighting (if not police) units, but many succumbed to drunkenness and gained a reputation as perpetrators of the most calculated and destructive reprisals. (Townshend, 1978: 111-112)

The creation of the Black and Tans and Auxiliaries opened up a chasm among British strategists. On the one hand, "it became clear that [the commanding officer of the police, General Henry Tudor (with Lloyd George's backing) was happy to condone, or at least turn a blind eye to, police reprisals against presumed Sinn Feiners" (Jeffery, 2006: 265); but the senior army generals were not. They were alarmed by the indiscipline of the paramilitary. Chief of the Imperial General Staff, Field Marshal Sir Henry Wilson, disliked the idea of an ad hoc force of ex-soldiers reinforcing the RIC. As historian Keith Jeffrey notes, Wilson's

apprehensions about this "panic measure of raising 8000 scallywags" were remarkably prescient... "I can't imagine what sort the men will be, no-one will know anybody, no discipline, no esprit de corps, no cohesion, no training, no musketry, no mess, no NOTHING. I don't like the idea... Then to make measures worse [General Officer Commanding in Ireland] Macready proposes to draft these mobs over to Ireland at once and split them up into lots of 25 to 50 men over the country so there would be no hope of forming and disciplining this crowd of unknown men. It is truly a desperate \& hopeless expedient bound to fail." (Jeffery, 2006: 263)

Wilson was no conciliator: he merely wanted army control over operations. He "wanted lists of known Sinn Féiners in each district of Ireland to be posted 'on the church doors all over the country; and, whenever a policeman is murdered, pick five by lot and shoot them!" (Jeffery, 20o6: 266). 
General Neville Macready was aware of the problem, "but for him the honour of the army outweighed everything else, including the success of the Government's policy and the survival of the Government itself" (Townshend, 1978:112). It was a case of placing organizational interests over national ones. Behind this was a reluctance to focus on the central issue:

There was ... a traditional ignorance of Irish affairs... By and large the Cabinet adhered to the "murder gang" theory ... and based on it a dual policy of "crushing murder" while reconciling the "moderates." But no real attempt was made to assess the strength and outlook, or even to prove the existence, of this moderate group on which the whole policy hinged. (Townshend, 1978: 203)

With the possible exception of Macready, the top generals were politically insensitive when it came to Ireland. Importantly, Henry Wilson was an Ulsterman passionately attached to the idea of Unionism, hardly the best qualifications for someone whose task was to oversee the withdrawal of Ireland from centuries of British tutelage. As for Macready, he

was, in Asquith's words, a man of "cool head" and "good judgment," and Lloyd George was evidently attracted by his liberal sympathies, which set him apart from the general tendency of the British officer corps. The problem was that Macready did not want the job. He professed to "loathe" Ireland "and its people with a depth deeper than the sea and more violent than that which I feel against the Boche." (Jeffery, 2006: 260-261)

\section{Guerrilla War and Counterinsurgency}

The British military, with few exceptions, notably failed to understand their adversary. First, by constantly referring to the IRA as a "murder gang," they suggested that it was a small, desperate minority, whereas it clearly enjoyed the active or passive support of the vast majority of the population. Little thought was given (except perhaps by Macready and some other senior generals) to the notion that a broad political solution was required, or that the elimination of existing armed bands would simply result in their replacement as new recruits stepped forward to take the place of those killed or imprisoned.

By defining the problem as one of eliminating a small hard core of active militants, the military fell back on their comfortable view that they were fighting another regular army, and that the principal task was to identify, 
track down, and eliminate (by arrest or by killing) small but well-defined armed bands. This was a mistaken view. The IRA bore more resemblance to a social movement than it did to a conventional army. The IRA developed as a series of locally and regionally based organizations, loosely held together by commitment to a common cause. Communications between IRA headquarters in Dublin and the regional brigades were cumbersome at best, and there was no automatic discipline and following of orders.

[IRA commander] Michael Collins did not plan, start, direct or control the war. No one did - no one person or headquarters that is. Most Volunteer units outside Dublin had been formed locally, elected their own leaders, funded, armed, motivated and trained themselves, planned and mounted their own operations, and succeeded or failed, with very little input from headquarters beyond demands for dues and reports... Each brigade operated in its own territory almost exclusively, requiring little coordination with neighbours... They fought their wars all on their own. (Hart, 2005: 242)

The diffuse and grassroots nature of the insurgency meant that British Army efforts to dismantle the IRA organization were unlikely to succeed. Exacerbating the bizarre diagnosis of a "murder gang" was the widespread, almost unconscious, contempt and underestimation in which the Irish were held by the British.

\section{Reprisals, Unofficial and Then Official}

During the opening days of the armed struggle, both the British Army and the IRA acted with restraint. Army officers and soldiers walking the streets of Irish cities were left to go about their business unharmed, and even attacks on Crown forces by the IRA were generally targeted at those officers who were a particular thorn in the side of the IRA. For their part, the army generally refrained from actions that would punish large sections of the population.

There were, however, limits to this mutual tolerance. The cultural norms that facilitated restraint eroded as tempers frayed and new repressive forces were recruited. Early in the guerrilla struggle, when British officers or soldiers were killed, troops would break out of barracks and go on a rampage, uncontrolled by their officers. Driven by the desire for revenge, they committed reprisals either against those they believed guilty, or more generally against the civilian population of the area. Houses were burnt, 
individuals murdered, and a climate of mayhem generated. With the arrival of the Black and Tans, these unofficial reprisals now became policy for the police. This alarmed both Macready and Wilson. They were concerned that army discipline might break down. Bowing before what they saw as the inevitable, and placing organizational goals above national ones, they accepted that they could not control their troops. Instead, in December 1920, they authorized "official reprisals," whereby the local population would be punished for aiding and abetting the insurgents.

The top army leadership was, on the whole, unhappy with a policy of indiscriminate reprisals.

[T] hose generals in Ireland who had thought deeply on the use of military force as a means to political settlement had never shared the Cabinet's apparent faith in its efficacy. Even apart from the style of violence employed by the police, which aroused their intense dislike, they believed that military rule in Ireland would only inflame age-old hatreds and impede the arrival of a lasting peace. (Townshend, 1978: 199)

\section{Flying Squads, Active Service Units, and the Great Hunt}

As the campaign of reprisals developed, the army persevered with its strategy of locating and eliminating the IRA as a military formation. While this was unlikely to produce a meaningful political outcome, house-to-house searches and tip-offs from informants did yield valuable intelligence, which in turn produced better targeted searches. IRA activists responded by going "on the run," moving constantly from place to place and staying wherever they could find shelter. Gradually, these men coalesced into "flying squads" and "Active Service Units." Their principal activity continued to be one of ambushes of British patrols, particularly in rural areas, and the assassination of police and army personnel.

Yet, even faced with an adversary that it had now forced into more or less permanent armed bands, the army tactics used to locate them produced meager results. During May and June 1921, as noted in the British Army's official history, Record of the Rebellion in Ireland, "it was decided to try the effect of 'drives' on a large scale over a large area, using the cavalry for the purpose. Every male civilian was to be interrogated, and all who could be identified as members of the I.R.A. were to be detained, and houses were to be searched for arms" (British Army, n.d.: 43).

Several large drives were undertaken. They failed to locate any significant number of rebels. According to the army's official history, 
The reasons that the visible success was not greater were in the first place that the identification of individuals was very difficult because the police, who had to be relied upon for this, were, in many cases, comparatively new to their areas, and, in any case, were men who would be compelled to continue living in the district after the troops had left. Secondly, a larger number of troops per square mile and a longer time spent in each area would have been necessary in order to discover hidden arms. Lastly, such operations could only be really effective when it was permissible to detain and intern every young man arrested unless he could produce satisfactory evidence of his loyalty. There is no doubt that a large majority of the men released through failure to identify them were in fact connected with the I.R.A. (British Army, n.d.: 44)

The final conclusion that all young men should be arrested unless they could prove that they were loyal supporters of the British administration in Ireland simply amounted to a charge of "guilty unless proven innocent" and an implicit recognition that the majority of the population were not active supporters of the British administration. The army now contemplated a war against the entire population to save it from itself - or from the supposed handful of extremists who had terrorized and misled the bulk of the population into following them.

\section{The War Turns Nasty}

The war was always a highly personal one. IRA units were recruited on the basis of kinship networks, and had strong ties to local communities. The principal method of attack was the individual assassination of a policeman, an informer, or someone who was suspected of opposition. Many more people were killed in this way than in roadside ambushes or armed confrontations with the security services.

In his analysis of who killed whom in Cork county, Peter Hart concludes that

ultimately, individual identities were irrelevant in the face of politically imposed labels and the ever-widening division between "us" and "them." Violence was not directed at people so much as categories (...) This little cycle of killings reveals the runaway tit-for-tat logic of the guerrilla war in Cork, driven by fear and the overwhelming need to respond (...) All of the victims were unarmed and helpless when shot and all were killed or kidnapped near home (...) Murder was more common than battle. This 
dirty war was waged largely by small bands of gunmen, young, tough, and barely under the control of their superiors. The "active squads" on both sides did what they liked, undeterred by orders or discipline further up the organization. Although the IRA, the RIC, and the army numbered in the hundreds and thousands in Cork, most of the killing was done by a few hard men... It was these men who forced the pace and, in a sense, the revolution came down to a confrontation between these groups, even if its victims were often innocents or outsiders. It was an intimate war, played out within homes and neighbourhoods, often between people who knew one another. (Hart, 1998: 18)

\section{The War Ends}

Throughout the period of armed conflict, the Lloyd George administration sent out, or listened to, a variety of peace feelers. However, so long as it seemed that the state might bring order to Ireland by suppressing the IRA - and David Lloyd George's military advisers were usually optimistic on this score - no meeting of minds between the Irish revolutionaries and the government was likely. Moreover, there were always those in key positions in British politics who insisted that there could be no negotiations with rebels and murderers. For their part, Sinn Féin moderates needed to be careful not to be outflanked by the hard-liners in the IRA. (Indeed, this tension was to come to a head in the Civil War of 1922-1923.) Peace talks were politically risky, and all sides approached them with great hesitation and trepidation.

As the conflict dragged on, as tactical innovation by one actor led to counterinnovation by another, all sides increasingly faced a scenario of escalating violence, with no end in sight. By 1921, the senior leadership of the British Army had come around to the view that a massive reinforcement of the forces in Ireland was both necessary and (through a reduction in troop levels elsewhere in the empire) possible. They wanted a new and more draconian strategy: martial law extended to the entirety of the island, trade with Britain and the rest of the world cut off, and the population forced into submission. For Sinn Féin, it was unclear whether this was a bluff on the part of the army, or whether - if it was not a bluff - the civilian leadership would acquiesce to the new strategy. They could not be sure, and, with a sense of stalemate in the guerrilla war, turned their attention to the negotiations in Downing Street. Talks between the government in London and the IRA/Sinn Féin leadership were started (with parallel discussions between London and Belfast), and a truce was declared in July 1921. 
The talks produced a compromise settlement: the terms of Ireland's new constitutional status were much broader than the Home Rule that had been on offer in 1914, but less than the full independence of an Irish Republic that had become the nationalist demand. Ireland was to be partitioned into two entities, and an oath of allegiance to the British Crown was required. An Irish Free State would come into existence in December 1922. Not surprisingly, the IRA split over whether or not to accept the terms of the London negotiations. A brief, but bloody, civil war (1922-23) ensued, the moderates prevailed, and the Irish Free State gradually evolved into the independent republic of the southern part of a divided island. In Ulster there were waves of sectarian rioting, with the police (the Royal Ulster Constabulary) openly siding with the Protestant unionists against the Catholics (Parkinson, 2004). A militantly Protestant state was created in Ulster which was reluctantly accepted by the southern Nationalists, who were in no position to do much about it.

\section{Analytic Reprise}

\section{Interaction of (Three Sets of) Strategies}

The three sides in this conflict constantly monitored each other and attempted to guess at their adversary's next move. All players responded to changing circumstances and to changes in strategy on the part of their adversaries and allies. There were systematic slippages, as one player failed to accurately grasp the intentions of another player, with predictable biases that exacerbated the conflict.

Some strategies clearly developed as direct responses to actions of other players; other strategies emerged from different sources. The British decision to release hunger strikers was a direct response to the protests generated around that tactic; and the perception that giving in to the hunger strikers simply increased the ranks of Sinn Féin by demonstrating British weakness then led to a reversal of British strategy and a "get tough" policy with regard to hunger strikers. This worked; and the nationalists dropped this tactic from their repertoire. The adoption of "official reprisals" and the tit-for-tat escalation of the war of assassination were mutually reinforcing spirals. Other strategies - such as the urban insurrection in Dublin on Easter Monday, 1916, and the targeting of the RIC in 1919 - were not responses to actions taken by the other side, but instead drew on shifting 
understandings, frames, and repertoires that are best explained as largely endogenous developments in strategic thinking.

Because of the disaggregated nature of the various players, including the coercive organizations of the British state in Ireland, they sometimes pursued internally incompatible strategies. When this happened, as with the introduction of the Black and Tans into the conflict, senior leaders, both civilian and military, regularly demanded a re-thinking of strategy to produce a clear and co-ordinated response on the part of the various repressive organizations. Because of political disagreements within the Cabinet, and the limitations of the frames used by British politicians, such strategic clarity was seldom forthcoming.

\section{British Framing: The Murder Gang and the Police; Rebellion and the Military}

The British had a strong preference for defining the Irish situation as "one for the police" and of using the police wherever possible. Ireland was, after all, part of the United Kingdom, and the kind of harsh counterinsurgency measures which might be employed overseas were unacceptable there (Muenger, 1991). When emergency formations such as the Black and Tans were raised, it is noticeable that they were formally attached to the RIC rather than to the army. Because of these cultural preferences, key players in the British state misjudged the impact of their measures on Irish opinion.

Its most fateful assumption was that public opinion would find the use of policemen, even though they were armed ex-soldiers, preferable to that of the military in the suppression of disorder. This was due in part to a failure to accept that the R.I.C.'s police capability had broken down and could not be restored by pouring in ill-disciplined recruits; and in part to a natural antipathy to military rule. (Townshend, 1978: 137)

In June 1921 Lloyd George was to tell the Cabinet that "the Irish job (...) was a policeman's job," and that if it became "a military job only" it would fail. But (...) the Government never defined the conflict, and the issue was obscured by attempts to distinguish between war and insurrection, summed up in Lloyd George's phrase, "You do not declare war against rebels." The Government was unwilling even to admit that a rebellion existed which had to be countered by military methods. The roles of the Army and the Police were never properly understood (...) There was no specific decision, but an acquiescence in the drift of events. (Townshend, 1978: 40) 
The British state was

placed in a dilemma by the identification of Sinn Fein with I.R.A. terrorism and violence. The increases in attacks on the Crown Forces, and the breakdown of constitutionalism and justice, compelled even the Liberals to accept the inevitability of a forcible response. For them the restoration of law and order was not just a convenient slogan behind which to temporize, but a moral priority. (Townshend, 1978: 201)

A second consequence was closely linked to this: the British failure to appreciate that once Ireland was embarked on the road to independence, the process would be rapid. Other cases of withdrawal from occupations suggest that once the process begins, popular mobilization in the occupied territory increases, the legitimacy of the occupation declines, and the withdrawal must be hastened. British withdrawal - in some form or other - was not only inevitable, it was urgent.

A further consequence was the failure to grasp the nettle of Ulster. When home rule for Ireland was announced, the Ulster Protestants mobilized to defeat the measure. They acted as spoilers, setting in motion the chain of events that would lead to armed conflict in Ireland. The British state was unable to produce a quick and decisive response, either with regard to Ulster or with regard to other aspects of the Irish crisis.

The dithering over whether the army would obey orders to suppress the Ulster militias (the Curragh incident) was merely the icing on the cake of a larger failure of political will. Of course, it can be argued that the British government faced objective, structural constraints. It faced a divided Ireland, part of which was a paranoid and sectarian Ulster; and it had to deal with an army heavily Anglo-Irish in sympathy and unwilling to think of itself as an obedient servant of the constitutionally elected civilian authorities. (This, in turn, owed something to the incomplete democratization of the British political system and the remaining importance of the monarchy and aristocracy in the civil-military chain of command.)

Of course the British government was also distracted by the titanic struggle of waging a total war and then by the complexities of peacemaking and of administering vast new additions to the empire in the Middle East. Moreover, the specter of Bolshevism and the reality of troubled industrial relations and massive strikes in Britain served further to distract British decision makers from effective intervention in Ireland. It is hardly surprising that there was little policy coherence with regard to the insurgency in Ireland. 


\section{Frames, Folk Sociology, Cultural Assumptions}

Throughout English society there was a widely diffused condescension toward the Irish which could at times become an attitude of contempt and prejudice. Examples abound. Lord Garnet Wolseley thought the Irish incomprehensible: "A strange, illogical, and inaccurate race, with the most amiable qualities, garnished with the dirt and squalor which they seem to love almost as dearly as their religion" (Muenger, 1991:144). As Townshend argues, "The British ... had responded to the latent hostility of the Irish with a benign contempt... [There was a] common British view of the Irish as a quaint, childlike race, often incompetent, and easily terrorized or led by extremists into violent behavior" (Townshend, 1978: 200).

The result, on the part of the British, of these deep-seated attitudes to the Irish was a "tendency to lay down the law rather than to consult, to coerce public opinion rather than seek its consent" (Townshend, 1978: 201). After noting that "the Irish are not easy to understand" (British Army, n.d.: 30), the army's official history went on to argue that the Irish had come to have little respect for law and order.

$[\mathrm{P}]$ erhaps the circumstance which has most influenced the character of the Irish is the fact that for many centuries... [T] hey have had little share in their own Government. There was, therefore, a general lack of respect for government (which was looked on as foreign) and consequently for the law. This has lasted for seven centuries and had bred in the Irish character a lack of discipline and an intolerance of restraint... There is not only no respect for the law; there is no common standard of public morality... Judged by English standards the Irish are a difficult and unsatisfactory people. Their civilization is different and in many ways lower than that of the English. They are entirely lacking in the Englishman's distinct respect for the truth... Many were of a degenerate type and their methods of waging war were in most cases barbarous, influenced by hatred and devoid of courage... There were undoubtedly many among the IRA who were moral degenerates, brutal and cruel to a degree, and there is an underlying cruelty in the nature of many Irishmen. (British Army, n.d.: 31-32)

British intelligence analysts and top military commanders nearly universally saw the IRA activists as coming from the lower orders of Irish society. The army's official history asserts that the leadership of the IRA were "largely the riff-raff of the country, men without means or education" (British Army, n.d.: 53). Not only Irish, but lower class as well. 
This assessment derived largely from an assessment of the nature of modern democracy. Britain was still in a situation of transition from aristocratic and gentry politics to mass electoral politics. Army officers were largely drawn from the middle and upper classes of British society. They viewed the expansion of the electorate and the rise of the labor movement with some alarm, and felt that the traditional "governing classes" ought to run politics. It is not surprising, therefore, that they viewed the IRA activists as coming from a social stratum that was unfitted to govern.

For the nationalists, the central framing device was that of a united people. Because this had been defined largely in cultural terms and in opposition to Protestant England, it took on a sectarian quality: Ireland was a Catholic nation. Class conflict was deliberately subordinated to the struggle for national liberation. For Ulster Protestants, the central frame was an uneasy juxtaposition of loyalty to the British Crown and an almost paranoid fear of betrayal by the British government and persecution by the Catholic majority in Ireland. For them, Home Rule meant Rome Rule.

Such a framing on all sides necessarily meant partition; yet for nationalists who aspired to a united Ireland this was a bitter pill to swallow. Until the moment of decision, the contradiction could be suppressed by ignoring or underestimating the size and strength of unionist opposition in Ulster, with the result that no solution satisfactory to all Irish (not to mention the English) was to emerge.

The entire struggle was invested by all sides with great emotional and symbolic significance. This was apparent in the initial reluctance on the part of British state managers to negotiate with "rebels" and "murderers," in the invocation of Catholic notions of martyrdom, first by Pearse and his fellow insurrectionaries in 1916 and later by Sinn Féin and the IRA, in the condemnation by both nationalists and the British state of "atrocities" committed by the other side, in the paranoid and hysterical sectarian fears of Protestant Ulster, in the refusal of the anti-Treaty die-hards of the IRA to swear any oath of loyalty to the British Crown or empire, and in many other ways. As D. G. Boyce has noted,

"Men do not in the long run fight for phrases, but for realities," remarked Asquith complacently in 1920. He could not have been more mistaken. The readiness to take up arms in defence of emotional symbols is always regarded as a particularly Irish characteristic, but in 1921 and 1922 a British administration, firmly supported by British public opinion, was prepared to declare war in order to ensure that the symbol of the Crown was incorporated into an Irish constitution. (Boyce, 1972: 183) 


\section{The Context of Global Revolution and Anti-Bolshevism}

The struggle for Irish Independence occurred within the framework of two larger contexts: the First World War, and arising out of that war, a global wave of revolution. By the time that widespread insurgency had developed in Ireland, concern with social unrest and Bolshevism was acute among British elites. There were frames within frames, the Irish problem being viewed in the larger imperial context. The immediate post-war years saw a wave of industrial unrest in Britain, and considerable numbers of soldiers (soldiers who might have been used in Ireland) were posted throughout Britain to serve as a force to suppress rebellion in the heartland. British elites were also panicked by the Bolshevik revolution and saw revolutionary threats everywhere. There was an early effort by the British authorities to find links - there were none - between the Bolsheviks and the Irish nationalists.

General Sir Henry Wilson was a conservative. As the war drew to an end, he was increasingly alarmed by the specter of Bolshevik-inspired social revolution. "Our real danger now,' he wrote in his diary on 10 November, 'is not the Bosh but Bolshevism"' (Jeffery, 2006: 229). He thought that General Macready faced a global nationalist and communist challenge in Ireland. He wrote in his diary that Macready "is fighting New York \& Cairo \& Calcutta \& Moscow who are only using Ireland as a tool \& lever against England, \& nothing but determined shooting on our part is of any use" (Jeffery, 2006: 263).

When it came to imperial possessions, Wilson's "gut reaction to disorder or challenge was simply to 'govern or get out'” (Jeffery, 2006: 239). Wilson identified four "storm centers": Ireland, Egypt, Mesopotamia, and India. The task was to define the troop requirements to keep all four quiet (Jeffery, 2006: 244). Adding domestic industrial unrest to these tasks would overly stress an army that in the wake of demobilization contained few long-term cadres and was poorly trained and motivated. The theme of too many challenges and not enough troops was to echo repeatedly throughout the course of the Irish conflict.

\section{The Disaggregated State: Organizational Goals and Perceptions Are Not the Same as State Goals and Perceptions}

When Sir Henry Wilson, CIGS, adopted a policy of "official reprisals" in Ireland, his principal motive was to protect the integrity of the army. It is fairly common for military organization to focus on narrowly defined 
organizational goals, to the detriment of the pursuit of the larger goals of state policy. There are obvious reasons for this kind of organizational parochialism, and it is not surprising that a central concern of state managers is to transcend the petty concerns of bureaucratic politics. That they often fail is equally unsurprising.

Not only were there vast differences in diagnosis and strategy between the police and the military, but the introduction of two largely uncontrolled paramilitary organizations, the Black and Tans and the Auxiliaries, triggered a spiral of indiscriminate violence that undermined such efforts at pacification as had been undertaken.

The central fact of British policy with regard to Ireland was that there simply was no coherent policy. The British government oscillated between concessions and coercion. Moreover, the British government employed various coercive organizations (British Army, RIC, Black and Tans, Auxiliaries) which adopted contradictory approaches to the problem and never properly co-ordinated their strategies.

This shifting and ambivalent approach generated the worst of both worlds for the British government, antagonizing large sections of the Irish population without effectively cowing them into submission. Importantly, the British government was greatly constrained by its tradition of rule oflaw and respect for civil liberties, even in wartime. Harsh repression, or even the imposition of a state of emergency, entailed huge political costs for the government in Britain. In the end, a rising tide of protest in Britain, together with a concern not to overly antagonize the American and Dominion governments, meant that the political costs of counterinsurgency in Ireland were simply more than the Lloyd George administration was willing to bear.

\section{References}

Beckett, Ian, ed. 1986. The Army and the Curragh Incident. London: Bodley Head.

Boyce, David George. 1972. Englishmen and Irish Troubles. Cambridge, MA: MIT Press.

British Army, n.d. Record of the Rebellion in Ireland. The National Archives, London WO 141/93.

Goldstone, Jack. 2004. "More Social Movements or Fewer? Beyond Political Opportunity Structures to Relational Fields." Theory and Society 33: 333-365.

Gregory, Aidan. 2002. "You Might as Well Recruit Germans: British Public Opinion and the Decision to Conscript the Irish in 1918." In Adrian Gregory and Senia Pašeta, eds., Ireland and the Great War: A War to Unite Us All? Manchester: Manchester University Press.

Hart, Peter. 1998. The IRA and Its Enemies. Oxford: Oxford University Press.

-.2005. Mick: The Real Michael Collins. New York: Penguin.

Jasper, James M. 2006. Getting Your Way: Strategic Dilemmas in the Real World. Chicago: Chicago University Press. 
—. 2015. "Introduction: Playing the Game." In James M. Jasper and Jan Willem Duyvendak, eds., Players and Arenas: The Interactive Dynamics of Protest. Amsterdam: Amsterdam University Press.

Jeffrey, Keith. 2006. Field Marshall Sir Henry Wilson. Oxford: Oxford University Press.

Muenger, Elizabeth. 1991. The British Military Dilemma in Ireland. Lawrence: Kansas University Press.

Parkinson, Alan. 2004. Belfast's Unholy War. Dublin: Four Courts Press.

Tilly, Charles. 1978. From Mobilization to Revolution. Reading, MA: Addison-Wesley.

Townshend, Charles. 1978. The British Campaign in Ireland. Oxford: Oxford University Press. -. 2005. Easter 1916: The Irish Rebellion. London: Penguin. 


\section{$7 \quad$ Infiltrators}

\section{David Cunningham and Roberto Soto-Carrión'}

While social movements are typically conceived as struggles between authorities and challengers, only analytic convenience justifies classifying all participants cleanly on one side or the other. The involvement of third parties with tenuous or partial loyalties to related causes, emergent schisms among challenging groups, and the myriad motives that define individuals' engagement in contention all but ensure that uncertain or duplicitous allegiances shape at least some participants' orientation to the collective struggle. Often, policing agencies - and sometimes the groups that challenge them - formalize this "gray area" of dual, contradictory, or fraudulent orientations by deploying agents to infiltrate competing parties.

Whether conceived as undercover agents, informers, informants, provocateurs, tipsters, or unknowing accomplices, these infiltrators ${ }^{2}$ exemplify the implicit complexities associated with players who navigate - often simultaneously - multiple arenas associated with contentious, political struggles. Here, we demonstrate the diverse ways in which infiltrators form and maintain complex and often contradictory relationships, given their interstitial position as both movement participants and representatives of the state. We unpack that role, demonstrating how easy assumptions about infiltrators as straightforward representatives of their employing agency, uniformly undermining the efforts of the groups that they penetrate, give way to more fluid conceptions of active and passive participation, and authentic versus deceptive behavior.

Infiltrators' allegiance to both authorities and challengers provides a critical touch point for conceptualizing movements within this volume's players-arenas framework. Drawing on the cases of three informants employed during the 196os by the US Federal Bureau of Investigation (FBI), we show how the infiltrator role is conditioned by a set of power relations

1 We thank Gary T. Marx, volume editors Jan Willem Duyvendak and James Jasper, and participants in the Mini-conference on Social Movements at the 2012 Eastern Sociological Society meeting for their helpful comments on earlier drafts of this chapter.

2 Note that we use the terms infiltrator and informant interchangeably here. The former term properly signals a broader range of roles, encompassing all of the terms listed in the first half of this sentence. In general terms, infiltrators include actors who penetrate target groups for any purpose rather than only to "inform" by gathering intelligence. However, all of the cases examined here involve infiltrators deployed as informants. 
maintained within specific arenas by key players. These players include, but are not limited to, the informants themselves, as well as state agents tasked with managing them, known within the FBI as "handlers." We contend that far from straightforward "agents" of the state, infiltrators balance ties to both police and activists, carving out a role relative to their state "handlers" and movement colleagues, toggling between passive and active participation in social movement activity to convincingly maintain their entrée and simultaneous allegiance both to authorities and challengers. Indeed, this interstitial position - between policing and activist arenas - defines the infiltrator role.

More generally, the complexities associated with the actions and motives of infiltrators provide a vehicle for rethinking their role as strategic players within contentious political arenas. Emphasizing informants' paradoxical relationship to other movement players simultaneously highlights and problematizes perspectives on social movements that focus on interactions between authority systems and activists who challenge the status quo. While usefully underscoring interrelationships among individual movement players and authorities - including police - this tradition typically overlooks the inherent dilemmas and contradictions faced by players whose roles do not neatly fit on one or the other side of that dichotomy. Conceptualizing the state as an arena comprised of multiple actors also speaks to players each having their own (sometimes multiple) strategic agendas and interests, which can at times jibe and at other times conflict in often unexpected ways.

As a result, we might productively conceptualize the fluidity of the infiltrator role as emerging within a set of embedded arenas that interact both horizontally and vertically. The horizontal dimension incorporates strategic interactions among infiltrators, handlers, and targets. The vertical dimension places the handler-infiltrator exchange within the broader context of the norms and practices of the handlers' agency within a broader state apparatus, as well as the institutional features and social position of the contending group being infiltrated.

\section{A Critical Look at Infiltration}

Nearly 40 years after its initial publication, Gary T. Marx's seminal 1974 article "Thoughts on a Neglected Category of Social Movement Participant: The Agent Provocateur and the Informant," remains the most influential existing work on infiltrators. Marx argued that although the use of 
informants within protest movements had been well-documented, little research demonstrated the logic of infiltration. He prodded analysts to take seriously how informants and provocateurs operate strategically (or not; as with much of Marx's work, he seeks to account for the full spectrum of motivations) and, in direct and sometimes indirect and often unintended ways, impact movement dynamics and the contours of authorities' control efforts.

Subsequent work has yielded significant insights into the structural conditions and instrumental and emotional conditions that govern movement participation. Other streams of research have taken seriously the processes through which opponents, typically but not always associated with the state, engage with movements. But this focus on movement players on both sides of the struggle tends, understandably, to assume straightforward and unambiguous allegiances either to challengers or authorities. Here, in contrast, we consider the interstitial position of infiltrators, emphasizing their "betweenness" as a lens through which to examine the complexities that govern the multiple and shifting arenas within which contention plays out.

The role of informants becomes particularly salient to efforts to conceptualize movements through the interplay of players and the arenas they occupy and (re)create over time. Such interactions shed light on how the individuals and groups that comprise "movements" interact with their social environment and how those milieus can at times work to control or accommodate action. While more recent work on the role of repression and social control within movements has attended to the prevalence and impact of state infiltration (Cunningham, 2003, 2004; Cunningham and Noakes, 2008; Davenport, 2005b; Earl, 2003; Marx, 1979, 1988; Noakes, 1998, 2000, 2003; Starr et al., 2011), scholars have generally been unable to fully address how the presence of infiltration or other forms of surveillance impacts the mobilization process or how infiltrators obfuscate the boundaries between seemingly oppositional movement players and the arenas within which they act.

A fresh conceptualization of the infiltrator role can place attention squarely on how authorities can operate in diverse, dynamic, and sometimes contradictory ways, breaking down conceptions of the state as a unitary body operating to advance a single set of interests and ends. The critique of simple essentialist takes on the state is a common one in the recent literature (see, e.g., Davenport, 2005a; Earl, 2011). Our discussion here echoes straightforward versions of that critique, highlighting the importance of disaggregating the state into discrete agencies that - both singly and interactively, as part of a field of authorities - may adopt distinct means 
and goals and operate with varying degrees of alignment and co-ordination. However, following Jasper's (2015) insight into the fractal character of arenas comprised of compound players, we also extend that critique, emphasizing the embedded nature of this multi-actor field. This focus on the struggles and tensions both within and across state agencies recognizes that agents (just like their constituent agencies) can have their own strategic agendas and interests, which sometimes align and in other cases conflict with those of their colleagues and the official policy that governs their agencies (Åkerström, 2006; Cunningham, 2009).

Additionally, focusing on various modes of infiltration captures repressive dynamics that move beyond strict conceptual distinctions between "passive" and "active" informants as well as conventionally recognized typological distinctions associated with state repression - e.g., divisions between "intelligence" and "counterintelligence" (Marx, 1988; Starr et al., 2011), "soft" and "hard" repression (Ferree, 2005), "institutional" and "situational" repression (Koopmans, 1997), or various repressive "functions" and "forms" (Cunningham, 2004). As the impact of infiltration - like other efforts to restrict or otherwise shape the actions of challengers - emerges alongside (and in interaction with) other forms of policing, legal action, media coverage, and so on, analysts can capture it most fully by examining how its constitutive arena shapes movement players' orientations and perceived and actual vulnerabilities to actions emerging within "the state."

Indeed, studying infiltrators provides a vehicle to observe how players interact with varied forms of what Koopmans (1997) refers to as institutional repression, while at the same time avoiding essentialized conceptions of what constitutes "repression." Examining the role of infiltrators provides a more inclusive understanding of repression, as the players/arenas framework seeks to "push beyond the vague and often circular language of power" (Jasper 2015) in order to more definitively show how players attempt to attain their goals. Recognizing the strategic actions of movement players across multiple, and conflicting arenas offers greater leverage to understand a more diverse set of repressive actions as well as to recognize that ostensibly repressive efforts can have divergent or ambivalent effects on their intended targets.

\section{Infiltrators as Interstitial Players in Embedded Arenas}

Within this broad conceptual framework, how might we characterize infiltrators? Unlike most players, whose moves can be understood interactively as they operate within discrete arenas, the infiltrator's defining 
characteristic is its interstitial position. Existing in a dual role that mediates the gulf between two competing parties - typically an authority and a challenger (Tarrow, 1998) - the infiltrator resides between state agencies and social movement organizations. Thus, the broad arena within which infiltrators operate encompasses both of these contending parties. However, as Jasper (2012) notes, arenas emerge at other levels as well. Compound players, including state agencies and SMOs, themselves constitute arenas, as their internal workings become observable through subdivision into their constituent actors. The inverse of this insight is that arenas themselves are nested - i.e., embedded within broader compound bodies that envelop narrower arena relationships in their organizational contexts.

The infiltrator role typically emerges around the informant's relationship to primary alters which provides the constitutive ties that activate each side of the "double-agent" position. In a US policing context, in particular with the FBI case examined here, the salient link on the authority's side is to the "handler," or state agent tasked with "developing" and "controlling" informants. On the movement side, this link centers on the particular activist(s) through which the infiltrator gains primary entrée and develops legitimacy within the group. While these relationships clearly are conditioned by differential power and control, we refer to them here as constituting the horizontal dimension of the broad arena that subsumes both challengers and authorities. Within this dimension, we strive to identify relational features that define differential capacities, or the variety and effectiveness of what Jasper (2015) refers to as the strategic means available to each party.

A second, vertical dimension ${ }^{3}$ emerges when we take seriously the narrower arenas embedded within particular compound players in a higherorder arena such as a state agency or SMO. Such agencies and groups are defined by their own internal processes, with intra-organizational relations shaping the infiltrator's milieu, by defining the character of the infiltrator's primary ties to state handlers and movement contacts. The structure and orientation of both state and movement organizations shape the capacities that define the leverage held by infiltrators vis-à-vis handlers/contacts at

3 While our emphasis on the "vertical" character of this dimension captures the key point that a handler or movement colleague's actions are conditioned by the nature of the decision-making structure of the body within which he or she operates, this organizational aspect also of course encompasses horizontal relations within the state and movement arenas. For clarity, we fold all of these organizational ties into the vertical dimension so as to distinguish them from the primary horizontal ties that constitute the infiltrator's interstitial role. 
any given point. This vertical dimension captures the broad arena that encompasses the contending bodies defining the infiltrator role.

One limitation of research focused on infiltrators and covert state repression generally is a continued lack of available representative data. While particular cases involving informants and provocateurs have become well-known anecdotally, it remains difficult to assess the comprehensiveness of those accounts, or the degree to which they might be generalized to any hypothetical population of informants. At minimum, the fact that the informants we tend to examine have, by definition, been publicly exposed may mean that they differ from the broader set of infiltrators who succeeded in keeping their identities a secret. While still acknowledging that significant and vexing constraint, examining comparatively the dynamics of particular known cases can provide a window into the processes that govern the interstitial nature of the infiltrator role. As such, we emphasize particular cases that reveal infiltrators' horizontal relationships with handlers and movement colleagues, as well as how those relations are conditioned by the organizational makeup of both state agencies and social movement groups.

The relative availability and openness of data related to informants associated with the Federal Bureau of Investigation (FBI) provides one window into how a cadre of informants operated within the context of a particular state agency. To assess and extend our conceptualization of the workings of the infiltrator role, we begin by considering case studies of three informants employed by the FBI during the 196os. Each of these cases involves efforts by the FBI to repress or otherwise monitor and control the actions of suspected threats to national security. ${ }^{4}$

\section{Cases: Infiltrating the Civil Rights Field}

The black freedom struggle has been well-documented, and many of its now-iconic images were captured by the prolific civil rights photographer Ernest Withers. Born in 1922 in Memphis, Tennessee, Withers experienced firsthand the impact of racism and racial conflict. Though he photographed the everyday life of black America in the South after World War II, his most

4 Given our focus on cases tied to a modern democratic state, we make no strong claims that our conclusions are generalizable to all regimes. Surely the particular dynamics described below would be conditioned by general political possibilities and constraints associated with broad political distinctions - e.g. Tilly's (1978) emphasis on "oligarchic" vs. "egalitarian" regimes - but we more measuredly assert that the general characteristics of the interstitial role discussed here would apply across a broader range of regimes and cases. 
poignant work was of African-Americans' struggle for equal rights. His photographs, such as the famous image of the 1968 Memphis Sanitation Strike with workers holding signs declaring "I AM A MAN," helped document the struggles and victories of black America.

Withers was on the scene for a number of seminal Civil Rights Movement campaigns. His photography has shaped resonant collective memories of the 1955 murder trial of Emmett Till, a 14-year-old African-American boy whose brutal murder for allegedly flirting with a white woman in Mississippi is frequently described as a key catalyst for the mobilization of the US Civil Rights Movement, and the 1957 desegregation of Central High School in Little Rock, Arkansas, which famously required the deployment of National Guard troops to defuse potential mob violence. The aforementioned 1968 Tennessee sanitation strike, in which some 1,30o black sanitation workers walked off of the job in protest of poor treatment, discrimination, and dangerous working conditions, is what ultimately brought Dr. Martin Luther King Jr. to Memphis and his untimely death.

Throughout the 196os Withers became a close confidant and trusted friend to key leaders, sitting in on some of the Movement's most sensitive strategy meetings. Rather than an active driver or shaper of action, he was best-known as an observer, a "passive" documentarian of both the crucial and mundane aspects of the Movement. His aesthetic acumen and longstanding commitment to the cause earned him the widespread respect of key leaders. Withers's insider status provided a platform for his photos to help create a new visual consciousness for the American public, and his images comprise some of that era's most powerful narratives (Willis, 2007).

But Withers also was known in FBI circles as "ME 338-R," his confidential informant number. From at least 1968 until 1970, he provided the Bureau with information, tips, meeting schedules, and photographs detailing his insider's perspective on the black community's fight for equality. Given his close relationships with fellow civil rights activists, near-universal entrée into Movement circles, and the importance of the historic images he captured, the 2010 revelation that he occupied a more complex dual role as a paid FBI infiltrator was treated as a bombshell that called into question bedrock assumptions about the Movement and its allies.

The Withers case provides an example of how such complexities shape the moral terrain upon which infiltrators tread. Rather than viewing his undercover actions in total conflict with his Movement efforts, Withers's paradoxical relationship with the FBI reflected his broader conflicted ties to law enforcement. A former police officer himself, he had been fired by the Memphis Police Department for his alleged involvement in 
bootlegging. The department subsequently cautioned the FBI against using him as an informant, a warning that shaped the relatively distant and informal nature of his subsequent relationship to the Bureau; prior to his emergence as a full-fledged informant in 1968, Withers had less formally received payments in exchange for information for nearly a decade (Perrusquia, 2010). And throughout that period, his connection to the FBI did not protect him from harassment by officials from other agencies. Following NAACP leader Medgar Evers's funeral in 1963, Withers was badly beaten by police and jailed for participating in a march outside the funeral home, reinforcing the sense that FBI work did not place one solidly on the side of the police or preclude providing aid - documentary or otherwise - to the Movement.

Such a balancing act also reflected the fact that "the Movement" itself was far from unitary, with Withers and others affiliating with certain segments while sometimes remaining wary of other factions. These personal distinctions informed his strategic aims as an informant and demarcated Withers's perceived allegiances between seemingly incongruous movement players. Many of Withers's reports focused on militants like Lance "Sweet Willie Wine" Watson, the prime minister of the Invaders, a Black Pantherstyled militant group in Memphis. His reports characterized Watson as a thief and conman who had planned an armed takeover of the campus of LeMoyne-Owen College. Similarly, Withers told the FBI that Charles Cabbage, the Invaders' co-founder, had dodged the draft, engaged in bomb making, and was involved with a prostitution ring. Withers's primary FBI contact, William H. Lawrence, commented on the tensions across Movement factions when he suggested that the photographer's cooperation with the FBI may have stemmed from his desire to "detect and deter violence," reflecting a "concern for the peaceful and effective preservation of the Civil Rights Movement" (Perrusquia, 2010).

Withers's association with the FBI stemmed from the Bureau's longstanding "racial matters" program, which primarily targeted various groups and individuals associated with the Civil Rights Movement. Agents' central emphasis was on the Movement's "subversive" potential stemming from its alleged ties to various communist interests, though they focused as well on the movement's extremist opponents, especially organized vigilantist vehicles like the Ku Klux Klan (KKK). Following the murder of three civil rights workers during 1964's Freedom Summer voter registration project in Mississippi, the FBI initiated a formal counterintelligence program against so-called "White Hate Groups," which at first targeted 17 KKK organizations and 9 other racist "hate organizations." 
FBI director J. Edgar Hoover and a set of assistant directors in the $\mathrm{Bu}$ reau's National Headquarters in Washington, DC, defined the purpose of COINTELPRO-White Hate Groups: "to expose, disrupt and otherwise neutralize the activities of the various Klans and hate organizations, their leadership and adherents." The memo initiating the program, sent to 17 of the FBI's 59 field offices (mostly to offices in the South, where KKK activity was centered), specified that agents fulfill the program's mandate by surveilling white hate targets "on a continuous basis," publicly exposing their "devious maneuvers and duplicity," "capitalizing upon organizational and personal conflicts," and blocking efforts to recruit adherents or build alliances (FBI, 1964).

As part of this effort, Bureau agents aggressively sought to infiltrate the KKK by extending their existing network of informants. Aided by agents' ideological overlap with Klan constituencies, they succeeded in recruiting informants to a degree that far outstripped their parallel efforts to infiltrate civil rights, Black Power, anti-war, and student movements during this period (Cunningham, 2004). A few months into the White Hate Groups program, agents boasted that they recruited infiltrators at an average rate of two per day. A later congressional report conservatively estimated that informants comprised at least 6 percent of the KKK's overall membership. By early 1966, the FBI's Charlotte field office reported that their coverage extended to hundreds of informants in 165 of the approximately 225 active Klan units in the state.

Throughout the mid-196os, North Carolina was far and away the most active state for the KKK; by 1966, the United Klans of America (or UKA, widely known to be the preeminent KKK organization of the Civil Rights era) boasted more members in the Tar Heel State than in the rest of the South put together (US House of Representatives, 1967; Cunningham, 2013). The most highly valued of those North Carolina-based Klan informants was George Dorsett. A longtime adherent of various KKK and segregationist organizations and a regionally known evangelist preacher, Dorsett joined the UKA in 1964, quickly rising to be a key leadership figure in that group's "Carolina Klan," which boasted an estimated 10,000 to 12,000 members by 1965 (US House of Representatives, 1966, 1967).

That year, Dorsett also served as the UKA's "Imperial Kludd" or national chaplain, and became a key part of the group's inner circle. He was a featured speaker at hundreds of UKA rallies across the South, frequently described as both the group's fieriest orator and someone who could reliably fill the donation buckets circulated at rallies. By 1966, the UKA was wracked by internal dissension and regular threats of emerging schisms, and Dorsett 
was at the center of this organizational strife. His conflicts with Bob Jones, the UKA's North Carolina “Grand Dragon" (or state leader), divided the state's membership, and the following year Jones formally banished him from the organization. With the assistance of his FBI handler, Dorsett formed his own competing KKK organization, the Confederate Knights of the Ku Klux Klan, which siphoned members away from the UKA while operating under the Bureau's watchful eye (Cunningham, 2004, 2013; Dorsett, 2005).

While Dorsett was among the FBI's most highly placed KKK informants, the Bureau's most infamous and widely known infiltrator was Gary Thomas Rowe. An eighth-grade dropout from Savannah, Georgia, Rowe moved to Birmingham, Alabama, following stints in the Georgia National Guard and the Marine Reserves. By his $26^{\text {th }}$ birthday, he was on his second marriage, working as a machinist at a Birmingham dairy, and fortifying his well-earned reputation as a tough bouncer and all-around hothead in the city's bars and clubs.

Throughout, he had a strong desire to work with law enforcement. His county sheriff aspirations were stymied by his lack of a high school education, but undeterred, he frequently boasted about being a cop or agent with the Bureau of Alcohol, Tobacco, and Firearms and convinced his Birmingham police friends to let him ride with them at night in their patrol cars. His constant brawling also made him a police target, as well as drew the attention of the local UKA "klavern" (KKK parlance for chapter). After multiple arrests, Rowe was pegged by bartender and KKK member Loyal McWhorter as a "good red-neck Klansman." Rowe was mulling the offer to join when a local FBI agent visited him in 1960 to investigate claims that his law enforcement boasts extended to his impersonation of a Bureau agent. Soon after, Rowe agreed to infiltrate the Klan for the FBI as part of its "racial matters" investigations (May, 2005; McWhorter, 2001).

Rowe's entry into the KKK came through the Eastview 13 klavern, among the most hard-core of the UKA's units. He enthusiastically participated in KKK actions, including a number of acts of violence (and, he alleged, FBI requests to "sleep with as many Klan wives as I could, break up marriages") (Rowe, 1976). Rowe's status was controversially revealed in 1965, after Viola Liuzzo, a Michigan resident, was gunned down on an Alabama highway while shuttling civil rights workers as part of the Selma-to-Montgomery march. The cold-blooded murder gained immediate national attention, and despite the fact that FBI director Hoover told LBJ that solving this sort of crime with no obvious leads would be "like looking for a needle in a haystack," the Bureau apprehended four suspects the following day. Rowe enabled the quick arrests, as he had been among the carful of klansmen 
that had pulled alongside Liuzzo's vehicle and shot and killed her. Rowe ultimately testified against his fellow Klan conspirators, denying that he himself had fired any shots (May, 2005; Rowe, 1976). Assessing Rowe's case, alongside those of Dorsett and Withers, allows us to explore the complex ways in which infiltrators serve as fluid players both within and across contentious arenas, and to examine both the horizontal and vertical dimensions that define these infiltrators' interstitial roles.

\section{Horizontal Ties: Modes of Recruitment and Oversight}

Infiltrators are commonly conceived of as a category of actor, tied to the state's interests and bound to the agencies that recruit and employ them. In that sense, their work as undercover "agents" makes them de facto extensions of that state and straightforward representatives of its goals and interests. However, the "infiltrator" category is considerably more fluid and heterogeneous - comprised of varying (and sometimes competing) goals and capacities - and should more productively be conceived of as a dynamic role that emerges within particular arenas of contention.

Perhaps the central element shaping the infiltrator role, and the capacity of the infiltrator to pursue goals distinct from those of the employing agency, is the initial mode of recruitment, which reflects the motivations of both the agency and the recruit and defines in turn the degree and style of oversight associated with the infiltrator's actions. In his later work on undercover policing, Marx (1988: 85) similarly identifies a range of entries into the "undercover role," from sworn agents working surreptitiously as part of their police position, to private police temporarily deputized or otherwise enlisted by state agencies, to private citizens enticed by an ideological belief in the policing cause, an interest in law enforcement work, a sense of adventure, or - more commonly - in return for money or to reduce or eliminate criminal charges or other legal problems they themselves face.

These diverse entry points shape each infiltrator's orientation to undercover work. The mode of entry also defines the infiltrator's relationship with the handler who oversees the operation and to whom the infiltrator typically reports information. Agencies such as the FBI typically charge handlers with the task of "developing" informants, a phrasing that signals the importance of the handler-informant relationship as well as the intended use of that bond to mold the infiltrator's goals to align with those of the state. In practice, the handler's orientation to informants varies significantly, and the evolution of the infiltrator role is significantly shaped by the degree of 
leverage associated with its mode of entry. Such structurally induced "leverages," of course, interact with individual proclivities and agency. Specific skill sets, thresholds for "deviousness" and vice, or a finely honed sense of righteousness may condition the infiltrator/handler relationship as well as the ways in which leverage is perceived and acted upon by both parties.

Indeed, Marx (1988:156) notes that the "controller-informer relationship is usually seen to involve the former controlling the latter," but highlights how the relationship in some cases can be upturned. Conceived as an exchange, the currency that informers provide centers on the provision of useful information that, in the short or long run, can be deployed to reduce the harm or challenge posed by the target being infiltrated. As such, infiltrators' resources tend to vary in degree if not in type, with the value of information rooted in its quality and utility, a function both of the infiltrator's ability to compellingly frame her contributions as pivotal and of whether that information might also be procured through alternate means (including by developing additional informants who might viably occupy an equivalent role $\left.{ }^{5}\right)$. An informant thus maximizes her leverage when occupying a "structural hole" between the state agency and its target - i.e., the sole link between these otherwise disconnected groups (Burt, 1995).

The currency that infiltrators receive in return, however, is more diverse - shaped by the motivations that define initial entry into the role, and reflecting the relative capacities of informers vis-à-vis their handlers. Infiltrators who respond primarily to tangible incentives - money, for instance, or a release from criminal charges - have less leverage in the exchange, as handlers can withdraw support if the infiltrator fails to perform. Informants motivated by the intrinsic rewards of the work or the ideological satisfaction it provides are less vulnerable to such resource withdrawals. Handlers thus have less control over their informants when the resources of exchange at their disposal are decoupled from infiltrators' primary motivations. The likelihood that an alternate informant could hypothetically provide the same information, thus lending a degree of redundancy and equivalence across infiltrators, interacts with these dimensions, altering the latitude that handlers will allow a given infiltrator in their abiding effort to ensure stable informant coverage.

George Dorsett represents a clear case of an informant, through his intrinsic motivations and leadership position in the KKK, who leveraged

5 Indeed, agencies such as the FBI frequently seek to develop multiple informants in the same groups, in part as a way to cross-check the reliability of the accounts offered by particular infiltrators. 
his significant capacities to nurture a loosely regulated and even collegial relationship with his handler. That agent, Dargan Frierson, was well-known within the Bureau for his ability to develop KKK informants, stemming in large part from his ability to relate to klansmen. He made good use of his deep local accent and was quick to disclose that his own grandfather had been in the KKK during the 1920s. He openly expressed his lack of enthusiasm about integration, and sometimes told klansmen to "cuss LBJ all you want; I don't think any more of him than you do." He would also "look the other way" when his informants were involved with cross burnings or other actions that, in his view, "wouldn't hurt anyone." To Frierson, working with top-level informants required such latitude. To maintain the trust required to access the KKK's inner circles, he reasoned, infiltrators like Dorsett "had to be out there, where it was going on. He had to talk like them, he had to act like them, he had to give fiery speeches" (Cunningham, 2009; Schlosser, 2007; Dorsett, 2005 Frierson and Dorsett, 2004).

As a consequence, Frierson's relationship to Dorsett developed as a partnership of sorts. The terms of Dorsett's recruitment focused on financial incentives rather than any leverage related to the possibility of his avoiding arrest or criminal charges. The FBI also lacked other informants among the elite leadership of North Carolina's UKA realm, and the absence of redundancy increased the value of Dorsett's reports and limited checks on his behavior. Dorsett, for his part, articulated his informant role as a means to "keep down violence and trouble." Though we might have cause to doubt his veracity, he frequently and proudly recounted particular instances in which he was able to stop a particular member from committing violent acts, though all the while he delivered "fiery" speeches at nightly UKA rallies that seemingly promoted violence and a disregard for legal authority.

This dissonance, while calling into question the veracity of Dorsett's selfproclaimed peace-keeping role, highlights as well his perceived orientation to the FBI in the context of his informant position. The lack of leverage that Frierson held over Dorsett was reflected in the latter's articulation of the infiltration dynamic; to Dorsett, the FBI was working with - and, in some cases, for - him, to accomplish a goal that he himself favored. While the terms of his partnership remained bounded by the organizational process of the FBI, Dorsett's leverage over his handler stretched and loosened the boundaries typically imposed on informants within the FBI arena.

Despite the KKK's heavy proscription on informing, such stretched boundaries enabled Dorsett to view his undercover status as an extension of his Klan work, and something that at times aided his efforts in the KKK. Such views were not merely self-delusions; Frierson's collegiality 
extended to providing Dorsett with protection for his colleagues to engage in perceived lower-level KKK terrorism such as cross burnings, as well as the resources to start his own competing KKK organization in 1967 (the Bureau ensured a foundation of members in Dorsett's incipient group, by stocking the new group with lower-level informants and instructing them to encourage their KKK colleagues to leave the UKA). Additionally, Frierson set up Dorsett, a house painter by trade, with jobs painting the residences of new agents when they moved to the area (Schlosser, 2007; Dorsett, 2005; Frierson and Dorsett, 2004).

Gary Thomas Rowe enjoyed similar freedom to take part in KKK violence with seeming immunity from FBI reprisals, though the dynamic that produced that latitude differed markedly from Dorsett's relationship with Frierson. In contrast with the UKA in North Carolina, which generally avoided acts of deadly violence, Birmingham's Eastview 13 klavern was among the roughest KKK units in the nation. This militancy added urgency to efforts to develop informants who might procure advance information about future violent acts. The tough, insular character of the Eastview unit also ensured that the task of placing informants, and in particular those capable of penetrating the klavern's violent core, would be more difficult (McWhorter, 2001).

During the initial meeting during which Rowe agreed to infiltrate the UKA for the FBI, his handling agent Barrett Kemp instructed him to avoid violence, in particular as an instigator. "Don't start anything," Kemp instructed. "Don't be the one to jump up and say let's go"' (May, 2005: 9). While Rowe, like Dorsett, agreed to infiltrate primarily for intrinsic reasons (in Rowe's case, a longtime fixation with law enforcement), the FBI's leverage early on centered on the Bureau's ability to "disown" and expose Rowe to criminal charges if implicated in a violent criminal act. This leverage, however, was tempered by the klavern's insularity, which contributed to the Bureau's inability to successfully develop informants other than Rowe. For a time, Kemp sought to mask that fact, and even lied to Rowe by telling him that he could cross-check the veracity of his information with reports from his (non-existent) stable of Eastview infiltrators.

Rowe's autonomy increased within a matter of months of his initial entry, when he was elected Eastview's "Klokan Chief." This new position as a valued klavern officer left him in charge of reviewing new membership applications and thus privy to the sort of inside information that garden-variety members never learned. He knew this position would both "please" his FBI handler and loosen the bounds of his Bureau-imposed role, increasing his capacity to engage in a broader range of actions without threat of sanction. 
By 1961, FBI officials were referring to Rowe as their "ace in the hole," and that year's Freedom Rides provided one early indication of the latitude that came with such status. When Rowe reported to the FBI office that the local police had pledged to give klansmen 15 minutes of unimpeded time to attack the group of interracial bus travelers, agents failed to intercede, instead turning the information over to the local police behind the plot in the first place. Rowe enthusiastically participated in the beatings, and ostensibly to maintain his cover Birmingham agents failed to restrict or otherwise penalize him. As still no comparable informants emerged, Rowe's leverage increased and his leash grew ever looser. The fact that he maintained his informant status throughout the first half of the 1960 on only exacerbated this degree of immunity from serious Bureau control, and called into question the balance between his service to the Klan and his efforts, as a state agent, to hinder KKK violence.

The key paradox associated with Rowe's multifaceted tie to the Bureau, as Marx (1988) observed in another context, is that his embeddedness in criminal violence enhanced his value as an informant but consequently made him more difficult to control. Similarly, as with Dorsett, the long arc of his informant service - Rowe continued reporting to the FBI throughout the mid-196os, until he was exposed in the Liuzzo investigation - increased the likelihood that the role would fail "to prevent harm or ... actually stimulat[e] or contribut[e] to it" (Marx, 1988: 203-204). This overall dynamic emerges both because continuous success as an informant requires repeated validations of one's activist bona fides, and also because each subsequent act reinforces and reproduces the latitude that infiltrators enjoy, as restrictions on any single act would risk exposing the agency's culpability in the full complement of criminal or otherwise unsavory actions.

In contrast, Ernest Withers gained significant leverage through his stature in civil rights circles, which enabled his unique access to the Movement. His involvement predated his recruitment by the FBI, and while his expected contribution allowed the Bureau to loosen its restrictions on informants to place him on the payroll, his relationship to his handler remained distant, centered on the professional exchange of information and money. While the FBI saw Withers as an important asset, agents were reluctant to work with an informant who had previously been fired from the Memphis Police Department. Ultimately, Withers's access to key information and his status as a respected member of the activist community overrode those concerns. In a report filed during Withers's recruitment, his handler William $\mathrm{H}$. Lawrence cautioned that: 
It is not believed that Withers can meet the Bureau's reliability requirements as a (racial informant) wherein his activities can be directed or controlled. However, because of his many contacts in the racial field, plus his indicated willingness to cooperate with this Bureau, (...) it is recommend that Withers (...) be contacted regarding general criminal matters. If in the course of these contacts he volunteers any information relating to security matters or racial matters, it of course will be accepted. (Perrusquia, 2010)

Given Withers's knowledge of the FBI's initial trepidation, he surely was aware of how his value enhanced his leverage by loosening the boundaries typically associated with FBI operatives. As one of only five paid "racial informants" in Memphis in 1968, Withers still engaged in Movement activities and remained loyal to civil rights causes, while reporting to Lawrence periodically on "racial matters." That relationship, however, lacked the personal component that characterized both Rowe and Dorsett's experience, and instead evolved as a business-like exchange. "Periodically, we would meet in person under what we hoped were safe conditions to personally exchange information, go over descriptions, any photographs, things of that nature," Lawrence later testified, adding that he paid Withers as much as $\$ 200$ a month - about $\$ 15,000$ a year today - for such reports (Perrusquia, 2010).

The Dorsett, Rowe, and Withers cases illustrate distinct kinds of relationships that define the infiltrator role within the context of its complementary handler relationship. The obvious contrasting case, treated counterfactually here but described in significant detail in criminological studies of police informers (see, e.g., Churchill and VanderWall 1988; Marx 1988), involves an infiltrator whose past criminal actions puts him or her in the debt of the handler, who can revoke any immunity or leniency previously granted as a condition for informant work. As the lesser capacity of those vulnerable informants causes the leverage pendulum to shift toward the handler, we might expect that the infiltrator's relationships both to their state employer and to the group being infiltrated to adjust accordingly. The contours of these relationships constitute one arena that defines the tenor of infiltration.

\section{Vertical Contexts: Organizational Structure and the Contours of Infiltration}

The handler-informer relationship is also embedded within the broader context of the handler's position within the overall organization of 
policing agencies. While many aspects of agencies' bureaucratic structure and process relate to this dimension, one highly salient consideration for infiltration dynamics is the classic policing tension between:(1) a desire for centralized coordination and uniform standards enabled by tight top-down control; and (2) the decreased quality of infiltrator information and reduced responsiveness that results from such higher-level supervision (Marx, 1988).

Reacting to that tension, FBI leadership sought to balance an overall emphasis on centralized authority - signaled by the fact that the vast majority of its counterintelligence measures against supposed subversives during the 196os targeted individuals and groups identified as threats by National Headquarters rather than by field agents - by encouraging local handlers and field office supervisors to exploit their local knowledge in the development and use of informants (Cunningham, 2004). Such organizational considerations define the vertical arena associated with the FBI itself, by shaping the ways in which handlers' actions relate to their relationships to their superiors and the Bureau's broader organizational routines. Here, we consider how such organizational policing dynamics shape the infiltrator's relationship both with his/her handler and the targeted group that provides the basis for undercover work.

The FBI's Birmingham field office, which shepherded Gary Thomas Rowe's entry into the Bureau, felt this core tension strongly. FBI director Hoover was initially wary of Rowe's background, and denied Barrett Kemp's recommendation in 1960 that Rowe's "excellent" potential should merit his development as a confidential informant. Only after Rowe was elected to a key officer position in the Eastview 13 klavern, thus gaining significant leverage through his unique ability to offer valued high-quality information, was Kemp's request accepted (May, 2005).

As noted earlier, Rowe's newfound leverage also earned him a longer leash; despite Kemp's general admonishments against participating in violent or criminal acts, he soon found himself able to engage in cross burnings without authorization or sanction. While field office reports to Bureau superiors were intended to control such activities, Rowe's unique contributions provided significant incentive to circumvent the usual rules. In at least one instance, the Birmingham office's report to headquarters willfully omitted Rowe's involvement when reporting on Klan violence. Interactions between Rowe and Kemp increasingly acknowledged the tensions between avoiding violence and procuring information. "We have to by law instruct that you are not to participate in any violence," Rowe recalled being told. "However, I know you need to do this ... to get the information. That's the important thing: get the information" (quoted in May, 2005: 25-26). 
When reporting the serious violence against the Freedom Riders in 1961, the handling agent sent a report to his immediate superior that distorted Rowe's role. That superior then ignored clear evidence to the contrary and told Headquarters that Rowe was not personally involved in the brutal bus station beatings.

Given Rowe's prized position, such autonomy was valued and reinforced. His handler Kemp complimented him on doing "one hell of a good job" and let him know that he considered Rowe the "finest" Klan informant in the Bureau. When, soon after, Kemp resigned his post with the Bureau, he reiterated this praise and encouraged Rowe to stay on as an informant. Rowe agreed, and his next handler effectively reproduced the dynamic, advising Rowe to “stay straight, keep your eyes open, don't get involved with anything, but furnish us the information." So long as he did the latter, the former warnings generally went unheeded. In 1965, when Rowe agreed to testify against his fellow klansmen for a murder that he himself was a party to and failed to stop, the FBI authorized a deal that won Rowe's immunity from both state and federal charges, the permanent relocation of his family, and a job in a locale of his choosing (May, 2005).

In other cases, the FBI's bureaucratic process managed accountability among informants through organizational controls that either drew informants in or maintained distance. George Dorsett's tenure as an informant clearly reflects the former approach. In North Carolina, repeated orders from National Headquarters to use informants to usurp the state's top UKA leadership overruled local agents' appeals to maintain stability in the state's Klan outfit and thus maximize the utility of Dorsett's access to the inner circle. As a result, Frierson partnered with Dorsett to foment a major leadership split and the formation of a new, Bureau-managed KKK outfit headed by Dorsett himself. The FBI gained leverage from the process, tightening the agency's ability to bound its prized informant's behavior, as Dorsett's incipient Confederate Knights of the KKK relied on Bureau support to ensure stable membership and dues payments.

In contrast, FBI agents in Memphis sought to balance the significant benefits of tapping Ernest Withers's access to civil rights circles with the risks they associated with his potential for impropriety and insubordination. To avoid the sorts of tangled complicities they weathered with Gary Thomas Rowe, for a long period the FBI avoided bringing Withers in as a full-fledged confidential informant, instead maintaining semi-regular contact through less formal requests for information about criminal activity alongside implicit encouragement to link that information to known civil rights activists. 
Such a move illustrates the importance of each of the dimensions we highlight here: the mode of recruitment, primary incentive structure, and capacities and leverage that characterize infiltrators' orientations to their employing agencies. The protective insulation that agents erected in their work with Withers was not possible in the case of the even-more-combustible Rowe, who had no prior history as a Klan member and thus required formal Bureau status to encourage his initial entrée into the Eastview klavern. Withers's willingness to provide information in return for monetary compensation also enabled the sort of straightforward businesslike exchanges that would not have been tenable for Rowe or Dorsett, whose motivations centered, respectively, on an unfulfilled desire to become a bona fide law enforcement officer and a wish to make use of police connections to advance careerist ambitions within the Klan. The fact that all three of these infiltrators could provide difficult-to-obtain information provided them with degrees of latitude greatly exceeding that of most garden-variety infiltrators, who often offered redundant and thus easily replaceable benefits. Such value increased their ability to negotiate arrangements that circumvented, at least in part, the FBI's tight centralized controls.

But even in cases where infiltrators enjoy significant autonomy from their employing agency, the dynamics of their informant work - and in particular the terms of the "horizontal" relationship with their handlers - are shaped by the vertical organizational context within which those handlers reside. Indeed, one might imagine an agency that required less day-to-day accountability or provided less input or bureaucratic control on the conduct of infiltrators as significantly shifting Rowe, Dorsett, and Withers's actions and experiences. Similarly, the organizational contours of the social movement organizations that each of these men infiltrated - from Rowe's highly insular Eastview klavern to the looser civil rights circles that Withers, with his established credentials and stature, could enter even in the absence of formal membership - shaped the overall experience of infiltration. Such vertical considerations serve as crucial contexts for infiltration, conditioning the experience by influencing the autonomy of both handlers and informants, altering the latitude associated with the infiltrator role and thereby the dynamics of its interstitial position.

\section{Interstitial Roles and Arenas of Contention}

If, as Jasper argues in the introduction to this volume, groups engaged in collective political struggles are "never completely unified," with individual 
members defecting or pursuing their own goals alongside those of the group, infiltrators represent perhaps the clearest (and most complex) case of players who balance multiple allegiances and interests. They themselves exist in an interstitial state, both in the broad arena that subsumes contending challengers and authorities and within the narrower organizational arenas that constitute specific groups on both sides of the struggle. While the nature of infiltration requires that individuals negotiate - typically through deception - multiple relationships within and across these arenas, the cases of Ernest Withers, George Dorsett, and Gary Thomas Rowe demonstrate that the contours of those relationships relate to infiltrators' strategic capacities and affective orientations, as they intersect with the structure and process of both their employing agencies and the group being infiltrated.

Here, we have captured the interactively constituted nature of infiltrators' strategic capacities - the fact that such capacities do not solely reside within individuals but rather are conditioned by the settings within which they are deployed - through our focus on the infiltrator-handler relationship as an exchange characterized by differing leverages possessed by one or the other party. Such an approach emphasizes the ability of both sides to deal in the currencies of payment, persuasion, or coercion, and recognizes that, over time, such exchanges are conditioned by individuals' ethical and deceptive orientations as well as the affective solidarities that characterize the primary handler relationship. Rowe, for instance, nearly abandoned his undercover role in the KKK when his handler Barrett Kemp left the FBI, and only agreed to stay on when both Kemp and his replacement provided assurances that maintaining his past successes was possible in the absence of his collaboration with Kemp (May, 2005).

Though the discussion here has focused predominantly on the manner in which informants attach to the state agencies that employ them, a complete analysis of the interstitial infiltrator role should engage with the full set of horizontal and vertical relationships that constitute the infiltrator role. In particular, the boundedness and insularity of targeted social movement organizations shape infiltrators' modes of entry, the degree of latitude and control that handlers can exert without compromising their cover, and their effectiveness - sometimes conditioned by emerging ambivalent solidarities - over time.

More generally, the cases examined here also highlight the very permeability of the boundaries that players face as they operate within and across multiple and embedded arenas. For informants, these boundaries can appear artificial, as they utilize available leverage to act strategically to 
extend or even rupture such constraints. Infiltrators perhaps appear unique as they necessarily navigate the uneasy waters of deceptive dual identities within competing arenas, drawing on capacities shaped by the leverage they possess on both sides of their role. The broader utility of the study of "undercover" players, however, might well be as a vehicle to illuminate the often-obscured negotiations that characterize how social movement players in general strategically navigate and reconstitute the boundaries that define arenas of protest.

\section{References}

Åkerström, Malin. 2006. “Doing Ambivalence: Embracing Policy Innovation - At Arm's Length.” Social Problems 53: 57-74.

Burt, Ronald S. 1995. Structural Holes: The Social Structure of Competition. Cambridge, MA: Harvard University Press.

Churchill, Ward, and Jim Vander Wall. 1988. Agents of Repression: The FBI's Secret Wars Against the Black Panther Party and the American Indian Movement. Boston: South End Press.

Cunningham, David. 2003. "The Patterning of Repression: FBI Counterintelligence and the New Left." Social Forces 82: 209-240.

-. 2004. There's Something Happening Here: The New Left, the Klan, and FBI Counterintelligence. Berkeley: University of California Press.

—. 2009. "Ambivalence and Control: State Action against the Civil Rights-era Ku Klux Klan." Qualitative Sociology 32: 355-377.

-. 2013. Klansville, U.S.A.: The Rise and Fall of the Civil Rights-Era Ku Klux Klan. New York: Oxford University Press.

Cunningham, David, and Noakes, John. 2008. "What If She's from the FBI?': The Effects of Covert Forms of Social Control on Social Movements." In Mathieu Deflem, ed., Surveillance and Governance: Crime Control and Beyond. New York: Emerald.

Davenport, Christian. 2005a. "Repression and Mobilization: Insights from Political Science and Sociology." In Christian Davenport, Hank Johnston, and Carol Mueller, eds., Repression and Mobilization. Minneapolis: University of Minnesota Press.

—. 2005b. "Understanding Covert Repressive Action: The Case of the U.S. Government against the Republic of New Africa." Journal of Conflict Resolution 49: 120-140.

Dorsett, George. 2005. Interview by David Cunningham, Guilford County, NC, 20 February.

Earl, Jennifer. 2003. "Tanks, Tear Gas, and Taxes: Toward a Theory of Movement Repression." Sociological Theory 21: 44-68.

—. 2011. "Political Repression: Iron Fists, Velvet Gloves, and Diffuse Control." Annual Review of Sociology 37: 261-284.

FBI. 1964. Memo from Director to SAC, Atlanta and 16 Other Field Offices, 2 September. Wilmington, DE: Scholarly Resources, Inc.

Ferree, Myra Marx. 2005. "Soft Repression: Ridicule, Stigma, and Silencing in Gender-Based Movements." In Christian Davenport, Hank Johnston, and Carol Mueller, eds., Repression and Mobilization. Minneapolis: University of Minnesota Press.

Frierson, Dargan, and George Dorsett. 2004. Interview by Michael Frierson, Greensboro, NC (video recording in possession of Michael Frierson). 
Jasper, James M. 2012. "Introduction: From Political Opportunity Structures to Strategic Interaction." In Jeff Goodwin and James M. Jasper, eds., Contention in Context. Stanford: Stanford University Press.

—. 2015. "Introduction." In James M. Jasper and Jan Willem Duyvendak, eds., Players and Arenas: The Interactive Dynamics of Protest. Amsterdam, Netherlands: Amsterdam University Press.

Koopmans, Ruud. 1997. "Dynamics of Repression and Mobilization: The German Extreme Right in the 199os." Mobilization 2: 149-164.

Marx, Gary T. 1974. "Thoughts on a Neglected Category of Social Movement Participant: The Agent Provocateur and the Informant." American Journal of Sociology 80: 402-442.

—. 1979. "External Efforts to Damage or Facilitate Social Movements: Some Patterns, Explanations, Outcomes and Complications." In Mayer N. Zald and John D. McCarthy, eds., The Dynamics of Social Movements. New York: Winthrop Publishing.

- 1988. Undercover: Police Surveillance in America. Berkeley: University of California Press.

May, Gary. 2005. The Informant: The FBI, the Ku Klux Klan, and the Murder of Viola Liuzzo. New Haven: Yale University Press.

McWhorter, Diane. 2001. Carry Me Home:Birmingham, Alabama: The Climactic Battle of the Civil Rights Revolution. New York: Touchstone Books.

Noakes, John. 1998. "Bankers and Common Men in Bedford Falls: How the FBI Determined That It's a Wonderful Life Was a Subversive Movie." Film History 10: 311-319.

- 2000. "Official Frames in Social Movement Theory: The FBI, HUAC, and the Communist Threat in Hollywood." The Sociological Quarterly 41: 639-656.

-. 2003. "Racializing Subversion: The FBI and the Depiction of Race in Early Cold War Movies." Ethnic and Racial Studies, 26: 728-749.

Perrusquia, Marc. 2010. "Photographer Ernest Withers Doubled as FBI Informant to Spy on Civil Rights Movement.” Memphis Commercial Appeal, 12 September.

Rowe, Gary Thomas, Jr. 1976. My Undercover Years with the Ku Klux Klan. New York: Bantam.

Schlosser, Jim. 2007. "The Klansman and the Lawman." Greensboro News and Record, 10 June.

Starr, Amory, Luis Fernandez, and Christian Scholl. 2011. Shutting Down the Streets: Political Violence and Social Control in the Global Era. New York: NYU Press.

Tarrow, Sidney. 1998. Power in Movement: Social Movements and Contentious Politics. New York: Cambridge University Press.

Tilly, Charles. 1978. From Mobilization to Revolution. New York: Addison-Wesley.

US House of Representatives, Committee on Un-American Activities. 1966. Activities of Ku Klux Klan Organizations in the United States, Parts I-V. $89^{\text {th }}$ Congress, First Session. Washington, DC: US Government Printing Office.

-. 1967. The Present Day Ku Klux Klan Movement. $90^{\text {th }}$ Congress, First Session. Washington, DC: US Government Printing Office.

Willis, Deborah. 2007. "In the Eye of the Storm: Ernest Withers, Camera Man." Crisis, November, 11. 


\title{
$8 \quad$ Liberal Violence
}

\author{
Strategies of Repression in Transitional Regimes
}

\author{
Vince Boudreau
}

Despite the prominence of violence in the authoritarian arsenal, dictatorships thread a line between stark repression and other modes of engaging rivals, critics, and members of society. Alongside state violence, one sometimes sees evidence of these alternative modes of engagement: in movement sympathizers who might have acted but did not, in bystanders who, made to fear movement victories, more or less willingly consume the promise of social order that state agents claim to deliver. Among the collection of institutions and actors we call the state, rivals may hold their ambitions in check while government seems firmly in control. Across the authoritarian order, the needs and ambitions of potential rivals are conciliated, intimidated, punished or eliminated. A dictatorship's efforts to retain power reflect a great many decisions, from which a strategy of domination emerges. ${ }^{1}$

For a variety of reasons, state violence against opponents cannot be exclusively attributed to the decision of authoritative state actors alone. Many repressive acts are committed by low-level actors in the heat of the moment and beyond the strategic control of the man or woman in charge. When student demonstrations near the executive mansion or palace, they confront rows of security forces who may have clear orders to shoot or hold their fire, but certainly also feel unease or even panic as demonstrations move closer. Moreover, in such situations, violence results from the interaction between security forces, state leaders, demonstrators, bystanders, and others: soldiers who may initially intend to hold their fire may fire into an angry crowd that seems dangerous - where they might have stood firm in their resolve against an apparently more measured protest march (Tilly, 2003). Nevertheless, there is some reason to imagine that an authoritarian regime pursuing acts associated with the repressive repertoire of dictatorship - such as disappearing activists in secret, rather than dissuading a

1 I gratefully acknowledge the help and criticism I received from Jim Jasper and Sid Tarrow in preparing this chapter. Sid in particular urged me toward a more interactive conceptualization of contention and repression, and while this work may fall short of what he envisioned, it is better for his efforts. 
public protest march - may more faithfully act on a strategic intention. Moreover, core political decisions about repressive strategy can set the tone for more contingent interactions among actors on the ground, and so we'll begin elaborating the dictators' strategic dilemmas with these big decisions.

I will first establish the importance of four big decisions in authorities' approach to dissent. In making the case, I concentrate on breaking down the exercise of power into constituent considerations, rather than explaining any specific repressive choice, or indeed, assuming that those choices sufficiently determine what violence will look like. The identification of these decisions leads us to a framework for thinking about how and why violence gets produced in one or another way, and what the consequences of that production will likely be for other players. At the core of my approach lies one large assumption: that a dictator would ideally seek to calibrate repression to achieve intimidation and control without triggering overly large and avoidable counter regime mobilization (Francisco, 2005) (although the definition of "overly large" and "avoidable" will vary from situation to situation). Strategic dilemmas attached to repression, that is, take account of how one seeks to strike at targets and what those strikes will likely trigger in other players. After sketching out the basic contours of these big decisions, I consider the regime's governing context, because variations in that context influence how the pursuit of coercion or conciliation interacts with the activity of other players in the contentious arena.

Taking my lead from the larger questions posed by this book, I will consider the construction of arenas and the interaction among different kinds of players as implicating each another: liberalizing pressure influences how a dictator will treat protest movements - but patterns of regime response to dissent also weaken or strengthen the democratic character of the political arena. Moreover, while these big decisions go a fair distance toward explaining alternative strategies for dictatorial control, they go only so far: by its very nature, repression reflects both cold calculations that discount the humanity of countless victims and the unthinking and often ill-conceived impulses of men (and boys and women) with guns. A fully interactive approach to the analysis of contention makes the causal weight of initial calculations, or even well-considered plans, fairly preliminary. I seek an understanding of how context helps explain the forces pushing on interactions among different actors in a contentious field, rather than a covering law that accounts for all decisions under given circumstances. Once we have established the broad contours of these decisions, I will move to a consideration of their relationship to patterns of interaction within a contentious arena under authoritarian conditions. 


\section{Who Is a Dictator?}

What exactly constitutes a dictator, or a dictatorship, and how do we link a regime designation like "dictatorship" to patterns of repression? For many, a propensity to repress is a defining characteristic of dictatorship, but to then ask about the relationship between dictatorship and repression amounts to tautology. I'll get around that difficulty by defining dictatorship as a concentration of power, the absence of checks on political authority, and restrictions on participatory politics. Nor will I insist that dictatorship has a special relationship to repression - except as a more regularly used tool in the struggle to maintain his or her authority (Boykoff, 2007). Repression alone, however, does not define dictatorship. Rather, dictatorship represents a particular institutional patterning, and repression is a consequence of answers to the puzzles thrown up by that institutional patterning. It follows, then, that other institutional relations between states and societies throw up different puzzles, to which different answers (contributing to the production of different patterns of repression or conciliation) may emerge. The discussion that follows focuses on the dilemmas that attach to liberalizing dictatorships, but does so because these dilemmas are particularly illustrative of the larger questions at hand. As I'll suggest, however, one can use the considerations that follow to think about repression in reliantly closed dictatorships, more open democratic regimes, or anything in between.

Moreover, pressures to liberalize represent core elements of the strategic dilemmas that will most concern us here: the quest for hegemony and control demands decisions about who to coerce, how much coercion to use, and what other political modes might be brought into play (Carey, 2006; Kowalewski and Hoover, 1992; Touraine, 1985). As they interact with restive populations, divided security forces, dissident members of the media, international forces, and a host of other potential players, these considerations pull regimes to different positions along a continuum between dictatorship and democracy. Modes of liberalization and reform, democracy and dictatorship, are therefore every bit as much a consequence of contentious interactions as a context for them. A dynamic, and interactive analysis requires that we allow the players, as well as the arenas and strategies, to evolve - making their reciprocal impact on one another a specific element of the inquiry. To illustrate the point, I will concentrate on dictatorships in liberalizing settings (or under great pressure to liberalize). 


\section{A Framework for Analysis}

Three separate questions help illuminate the strategic dilemmas under consideration. The first investigates the structural conditions under which these strategic interactions take place - conditions that both shape decisions and evolve in consequence of them. The second involves the elements of dictatorship strategy, here depicted as four decisions that shape repression. The third involves the production of contention itself, conceived as the process by which others in the contentious arena interact with these decisions; in what follows, I identify four significant actors, including the dictator's inner circle, and theorize their interactions with one another, under given sets of external conditions.

Dictatorships seeking to quash or manage dissent face four crucial families of decisions: targeting decisions, intensity decisions, exclusivity decisions, and publicity decisions. Targeting decisions help determine who receives the state's coercive attentions and by what criteria those attentions are allocated. A key element is whether authorities target kinds of people or kinds of activity (Boudreau, 2009). Intensity decisions are initial cuts on how deadly or violent state coercion will be, although actual levels of violence are extraordinarily dependent on interactions among actors in the contentious arena. Regimes that imprison are coercive, but less intensively so than dictatorships that more often torture or murder - although incarceration duration also matters (Kowalewski and Hoover, 1992). Exclusivity decisions shape the extent to which coercion carefully targets perpetrators and subversives, distinguishing discriminating regimes from those that sow terror more indiscriminately, sweeping up involved and uninvolved citizens in their dragnet (Gurr and Lichbach, 1986). Publicity decisions involve whether the state acknowledges or claims responsibility for its repression, how broadly it publicizes this responsibility and to what end, and how (or how effectively) it justifies and explains repression to its victims, dissidents, bystanders, and elements of its internal apparatus (Earl, 2011).

The strategic element of these decisions reflects a concern (our analytic concern and the concern of state actors) for how they will interact with other players in a contentious arena. At least four different players matter: the dictatorship's leading decision makers (our main object of investigation here), targets of repression and coercion, bystanders (including both individuals and organizations), and secondary factions of the state apparatus. Each decision taken in relationship to an act of dissent or resistance will potentially have some impact on some or all of these actors, and so 
in choosing repression, conciliation or any other political move, players must take broad account of its impact on the balance of political forces.

Authorities' strategic decisions, the responses of other players to those decisions, and the interactions that ultimately produce contention are influenced by the general setting of politics - and the range of significant contextual factors with both domestic and international roots is potentially quite long. I concentrate on two such elements, because they have direct implications for the main lever I am trying to put in play: the relationship between repression and inclusion in how authorities manage dissent. My choice is deeply influenced by a model of political context often deployed by Charles Tilly. In many of his later works, Tilly liked to arrange his thoughts about state-society relationships in a $2 \times 2$ grid in which degrees of democracy and variations in state capacity interact (Tilly, 2001). The state capacity axis is more or less straightforward, but in thinking about gradations of democracy, it is wise to take on board the complexity of Tilly's appreciation of the concept. For him, democracy involved three important elements: status equality between government and governed, binding consultations with citizens, and the protection of basic rights and freedoms. The interaction of all three elements matters for the analysis that follows.

\section{Considerations of Setting}

The choices and potential consequences of activity open to political authorities connect to elements of the larger political setting in several important ways. The decisions that state leaders make accumulate to produce and sometimes change that context, and in writing this, I am mindful to avoid reifying the political structure in ways that separate it from action. Nevertheless, longer term parameters of political activity make some answers to the decisions I've discussed more likely than others - particularly parameters connected to the extent and efficacy of voice in the system, and the resources open to state authorities who determine that dissidents have exceeded those parameters. These considerations bring us to Tilly's typology of democracy and state capacity.

The social and political life of contention and state violence depends on the larger relationships in which that contention unfolds. State actors and dissidents both evaluate the level of support that their claims generate, and the support they can expect for any tactic (Tilly and Tarrow, 2006: 70-71 especially). A group of bystanders in a semi-democracy may approve of demands for land reform, but reject efforts to occupy and burn government 
offices in pursuit of those demands. While groups in government may not support a call for new elections, they may unite against a government that uses deadly force to repress those who do. Actors will respond to tactics in relation to the range of political performances that are normatively in play, the institutions of repression and representation at hand, and the political dispositions of other actors (Davenport, 1995; Ondetti, 2006; Tilly, 2000). Context profoundly influences the strategic resonance of any decision or act taken in a contentious arena, and so shapes how contention itself will ultimately emerge (Tilly, 2003). In this sense, a dictator's decision to behave in one or another manner is merely an input into that set of interactions that ultimately shape contention.

Yet unlike production of collective violence (which always emerges as an interaction among at least two groups) or contention in more liberal settings (where the arena is open to a fuller range of participants and observers), there is some reason to privilege at least some dictatorship decisions over the interaction of different players in the production of repression. Dictatorships often work to clear the political arena before contention begins or following a spate of demonstrations - eliminating or isolating so-called enemies of the state in repressive acts designed to preempt politics, demobilize bystanders, and isolate activists from one another. Such acts of preemptory or retaliatory repression may be conceived and executed in more unilateral fashion (indeed, are designed precisely to be unilateral). To the extent that such attacks take place away from the sites of public politics, moreover, a regime will have more discretion in whether or not it will own up to its role in such attacks. Within a more fully elaborated political arena, of course, the broader range of interactions comes into play to shape contention - think of the mass demonstrations in many contemporary democracy movements. But here, too, decisions to repress may be taken by fairly isolated power holders and more faithfully carried out by a security force apparatus that stands more apart from society. For instance, while a whole range of actors produced the contention in Tiananmen Square, core elements of the violence followed from decisions taken by a small cadre of leaders removed from the scene (Nathan et al., 2001).

The point is not conceptual but empirical: dictatorships work hard to clear the political arena of adversaries, to establish or defend their capacity for unilateral activity. Some are more successful than others. Where dictators are more isolated and dictatorships more centralized, where bystanders fear punishment for expressing dissent, where media is stifled and free assembly impossible, the conceptualization and design of repression may be more unilateral, and more directly reflect regime calculations. 
A regime must decide how it will resolve grievances and hear claims meaning both what institutions it will deploy to hear social demands and how access to those institutions will be distributed. In theory, a democratic government institutionalizes arenas for the expression and resolution of popular demands, and takes root as people commit to these venues in preference to efforts at self-help (Huber et al., 1997; Jenkins et al., 2008). To produce this effect, however, sufficient relevant institutions must exist, must provide roughly equal access, and must function with some impartiality and effectiveness. These conditions are not always met, even in acknowledged democracies. In dictatorships, the question of whether these institutions should exist and how impartially they function is even more open-ended. Dictators may seal their rise by eradicating representative institutions and routine avenues for resolving grievances: disbanding courts, closing the press, and pursuing a closed policy-making process.

Dictatorships may so compromise government institutions as to drive claim making away from the representation of grievances to government (Boudreau, 1996). Contention in such situations can range from broadly based, often explicitly moderate democracy protests, to narrower and more (tactically and politically) revolutionary uprisings, depending in part on whether the regime divides, whether bystanders involve themselves in the movement, or whether and how international forces weigh in. Conversely, as dictatorships liberalize, they at least open the prospect of less contentious modes of dispute resolution and claim making, and radical activity (either radical state repression or radical anti-state tactics) may attract less support (Ondetti, 2006). Nevertheless, we also know that liberalizing dictatorships predictably generate discernable spikes in both social and state violence (Fein, 1995; Mansfield and Snyder, 2002; Roessler, 2005; Savun and Tirone, 2011). Accordingly, officials and activists in such settings will be tempted both to tune their actions to emerging political norms and to act on their persistent apprehension of existential threats requiring a strong response. Further along the democracy spectrum, the sense of existential threat probably grows less tenable, and authorities may not be able to use strong violence without calling forth a torrent of social criticism or mobilization. Nor, given the range of other options open to them, would violence necessarily be the most attractive political option in such cases, for the settled institutions of political representation often are all authorities need to domesticate contention (Lindekilde, 2012).

Dictatorships, however, cannot rely on that same institutional logic to diffuse resistance, both because they have not developed representative institutions with strong reputations and because they often face more sharply 
counterhegemonic challenges. Given both considerations, dictatorships can be expected to take more active steps to thwart perceived enemies. Authorities in such circumstances often present themselves as under attack: besieged by communists, hamstrung by inefficient civilians, beset by the clamoring rabble with their social needs, undermined by foreign enemies, or merely destabilized by a pressing need to develop, to modernize, and to build a future. If democracies can often manage dissent through political routines, dictatorships often must position themselves as countermovements, setting out to defeat their opponents (Johnston, 2012; Kowalewski and Hoover, 1992).

High capacity dictatorships will be able to treat more opposition movements as threats that require a response, while weaker or more divided dictatorship will probably need to ignore some challenges, conciliate others, or work through non-state actors like independent militia or warlords (Migdal, 1988). Weaker authorities may choose to concentrate their defenses around regions or institutions that matter most to their power: national centers, border areas, or places with particular resource endowments (Tilly, 2003). In either event, authorities settle for something less than complete hegemony over all populations. Where weak governments define threats as rooted in certain modes of behavior, they may de-criminalize a range of activities. Liberalization often opens the door to more formidable democratizing challenges, of course - but offers the immediate promise of alleviating policing burdens on the state. In such cases, however, unpredictable and exemplary acts of violence (the disappearance of a human rights activist, or the assassination of an opposition leader) can seem a low-cost alternative to systematic repression of proscribed, or undesired, activity.

\section{Four Big Decisions and How They Matter}

As I noted, four main decisions shape a regime's approach to repression: targeting decisions, intensity decisions, exclusivity decisions, and publicity decisions. In all but the most totalitarian orders (and certainly when liberalization processes are underway), authorities must contend with the interaction of their own moves with those of other actors in the production of repression and contention. Three of the four decisions are what we may call battlefield decisions, influencing who gets "hit" and how - and battlefield decisions always interact with the decisions and actions of others in the contentious arena. The fourth involves regime efforts to frame their actions for other audiences, and so to control repression's political consequences. 
Let us take up these four decisions in turn, bearing in mind that however neat their rhetorical separation may be in this work, the issues are typically more mixed together in the act itself.

In making what I have called targeting decisions, authorities work out how they will regard the sources of resistance to their regime. In many cases, historical interactions between authorities and dissident social groups produce clear ideas about the sources of subversion and danger in a society, ideas that can emerge though historically grounded analysis and research. Some decisions about who to target may be linked to state resources, with weaker and more poorly supplied authoritarian orders compelled to let some dissent slide, or to subcontract repression out to local power brokers. In addition to these considerations, authorities arrive at some understanding about whether the threats they face typically emanate from subversives who represent danger in their very person, or from a range of destabilizing and harmful activities (no matter who commits them) (Boudreau, 2009; Haberkorn, 2013). Why a regime follows one path or another has something to do with its overall system of power, but also reflects relational mechanisms that activate boundaries between political groups and polarize relationships among them (Tarrow, 2012). That is, like most of these considerations, questions and answers are historically constructed via social and political interactions, rather than merely dreamed up by dictators.

Among varieties of repression and violence structured as an effort to identify irredeemable subversives, we find ethnic cleansing, campaigns to eradicate communists or ban membership in categories of organization, and violent, often summary, executions of criminals brought to grief less because of a specific crime than because they have been profiled as members of a recidivist underworld. We also, however, find activists in zero sum conflict with authorities over power and resources (something quite different than the activist demanding broader representation or access to political institutions). Where political challenges emerge in pitched and zero sum terms, the legality or illegality of an activist tactic is less at issue than the capacity of activism to accumulate power against the regime. In such situations, authorities will look past what an activist does and concentrate on who they are, how powerful they seem, and what they are seeking. In this sense, the committed revolutionary or nationalist - and even the democratic reformer - find their place alongside ethnic or religious others: all standing in existentially threatening contentious relationships to the regime. In such cases, state attention will not linger on the peacefulness of a march, the apparent innocence of a mass education meeting, or even the content of a religious ceremony. People will face state violence 
because they have become subversives, rather than that they have acted subversively.

In contrast, repression and violence meted out against proscribed acts require state authorities to link punishment with particular events, often justified in some public explanation or juridical process. Even a repressive order may be policed by clear rules of conduct and behavior, so that shrewd activists may find ways of expressing dissent - often in deeply ineffective ways - that will not draw strong retaliation. Prosecution can be as much about changing patterns of behavior than about apprehending subversives (Beetham, 1991; Earl, 2003; Gilley, 2006; Oberschall, 1973). State repression and policing aim at preventing dissidents from acting on their views and steering bystanders toward modes of behavior that don't disrupt the prevailing order. In such cases, we must naturally pay close attention to how repression takes place, but must also attend to the ways in which authorities write and rewrite the rules of conduct, the battles that take place over those legal processes, and the consistency with which the law, once written, is applied. (In contrast, where dictators seek to root out threatening individuals, the law may be a mere footnote and place little restraint on coercion.)

Between a regime seeking to proscribe specific acts, and the anti-subversive purges of those eliminating classes of demonized enemies, lies a middle ground of great interest: published laws and regulations are sometimes insufficient guides to those wishing to stay on the right side of the law. Civil liberties and freedoms may be defended rhetorically but violated in practice. Formally legal and typically unmolested demonstrations may, from time to time, come under violent attack. Movement leaders and organizers may disappear - not every day, not whenever they make themselves known, perhaps not even frequently. But sometimes they disappear, and as a result, activists and claim makers never know what the consequences of their activism will be. Under such circumstances, repression and violence - acts sometimes even condemned by authorities - obscure the line between the permitted and the banned (Kirschke, 2000).

Rather than regarding this inconsistency as random, I approach it here as a tactic, and one particularly effective in hybrid regimes or liberalizing dictatorships, when a broader discourse of human rights and civil liberties coexists with persistent authoritarian elements. In such cases, authorities sense that persistent and existential subversives exist and threaten the regime, but are constrained by a process-based politics that protects some rights and freedoms. The resulting violence is unpredictable, and frequently framed - after the fact - as the work of unknown zealots in government 
service, vaguely defined enemies of the peace, or undisciplined but lowerranking soldiers and police officers. Authorities can claim to preside over a rule-based political order and benefit from a terror that sets those rules to naught.

Regimes also shape the intensity of violence - although in this connection, the term decision doesn't reflect the reality that a great many acts of violence are shaped by interactions between a great many players. We now know enough about violence to understand that its production is an interactive and iterative process, and many acts of repression and coercion are unplanned escalations of what was initially intended to be a more measured or restrained response. Nevertheless, strategies based on punishing proscribed acts often must fit a response to a specific kind of crime, positioning itself as measured and merited. The audience for this projection includes those who are apprehended by the state, but also onlookers who may even see authorities as legitimately acting to protect the public order. In contrast, authorities setting out to meet an existential threat to their power will cultivate a sense of this threat, and an image of themselves as strong enough to overcome it. Repression in such cases faces significantly less pressure for restraint. Rather than redirecting proscribed behavior via sanctions, authorities seek to overcome or eliminate the challenge, and this broader, more categorical mandate allows repression to be guided by purely battlefield, rather than political or social considerations (Tilly and Tarrow, 2006). Sometimes the battlefield logic will recommend restraint - but where it does not, violence can peak sharply and often spreads to involve non-state actors; indeed, Tilly's work on collective violence (2003) locates the escalation and spread of that violence in the changing relations and unpredictable interactions among a broad range of involved actors. Action-based repression tends more exclusively to involve professionals, and while these still escalate and involve broader categories of actors, they do so less frequently. Nevertheless, some of the sharpest escalations in action based repression involve vigilante violence (i.e., the spread of violence from professional to non-professional violence specialists) frequently as a form of resistance or as criticism of perceived state inactivity (Goldstein, 2003; Tankebe, 2009).

As with the first dilemma, liberalizing or hybrid regimes produce tension between the comparative restraint and more unfettered battlefield violence. In this intermediate zone, violence can be shocking because it erupts in what are commonly civil encounters. Tensions between efforts to enforce the rules of a liberal order and the defense of undemocratic power and privilege produces instances of students who disappear, human rights activists shot on the way home - intense violence that intrudes on 
the more measured exercise of state authority. Such settings also produce unpredictable escalations of violence. A line of police who fire into demonstrators may have intended to do so all along, but this may also be the undisciplined act one would expect from security forces who believe they are under dire threat but have been ordered to practice restraint. That plausibility - the chance that a case of jitters, rather than the regime, is to blame - is the knife's edge on which the whole approach to social control comes to balance. Episodes of intense but unpredictable violence derive their power to frighten, to anger, and to confuse via the juxtaposition of bloodshed and more civil political relationships, rather than through the simple pervasiveness of violence (Curaming, 2013).

Third are exclusivity decisions, meaning how carefully the regime confines its attack to specific targets. Exclusivity in part reflects the capacity to discriminate, something far more likely in acts of targeted assassination, arrest, and torture - and less possible in the heat of a demonstration or riot, when interactions among actors may cause things to escalate. But standing apart from those moments of public confrontation, regimes also ask the strategic question: under what conditions is indiscriminate violence useful, and when does it harm regime efforts to stabilize itself (Francisco, 2005)? Three elements of an answer spring to mind. First, a regime may see subversion as pervasive and intractable, imagine that enemies of the state lurk everywhere, and believe that stability will only come through force of arms. In such cases, widespread and indiscriminate violence can seem the best way to keep opponents at bay. Second, the targets of regime violence may be both politically or physically isolated, and so largely unable to make common cause with others in society; under such conditions state actors may have no real incentives to discriminate in the exercise of violence. Finally, authorities may promote the idea that bystanders and sympathizers might "unfortunately" become collateral damage as a way to clear potential support away from the primary targets of state repression (Gamson, 1975; Wood, 2007). Of course, collateral damage wrought by indiscriminate violence may convert bystanders to activists and populations may break through their isolation and ally with other activist collectives, and so we should pay attention to the sorts of conditions that influence the way discriminate and indiscriminate violence will play out, and in particular, how people react (politically and emotionally) to that experience.

The final set of decisions contains what I have called publicity decisions: the choices regimes make concerning how and whether they will communicate information about their repressive activity (Jasper, 2006). First, will government authorities conduct violence in public view, or in any public way 
acknowledge responsibility - or will attacks take place in clandestine ways and in out-of-the-way places (Anderson, 1990; Earl, 2011; Kirschke, 2000)? In the former category we find military shows of force at demonstrations or public executions, in the latter, we can place activist disappearances or clandestine assassinations. Second, authorities must decide how, and how vigorously, it will need to explain its actions. Obviously, secret killings seldom get in the way of explanation - though dictators and mobsters both sometimes turn speculation about how someone might "run into trouble" into a practiced art. The public discussion of other modes of repression

potentially conveys some combination of two things: a sense of capacity to apprehend and overcome resistance, and a sense that state activity is just. The first element is useful to establish hegemony and dominance (particularly when those things are under attack); the second speaks to legitimacy and so is useful in weaning potential support away from movements and their discontents. Unacknowledged state attacks may also convey capacity, but add to it a sense of impunity: a hidden hand that lays low the enemies of the state can make authorities seem more powerful (Bonner, 2009). On the other hand, the absence of any strategy to publicize or communicate violence suggests the primacy of instrumental concerns in the attack.

\section{Players and How They Matter}

Every move in the direction of repression has at least two objectives: what it accomplishes in itself, and what it communicates in that accomplishment. Repression certainly influences - even eliminates - its target. But it also communicates capacity, stability, resolve, a sense of social order - or the opposite of these: weakness, instability, indecision, or the violation of some values or norms. In killing, imprisoning, or "disappearing" opponents without due process, dictatorships at once eliminate threats and communicate a capacity to act against challengers. When clearly communicating the whys and wherefores of an arrest or a killing, a regime both apprehends an offender and lays down rules of behavior that others might follow.

Apart from the dictator's inner circle, which we here conceptualize as moving with a single and undivided purpose, at least three other players matter (in any contentious episode). ${ }^{2}$ First is the target of state repression,

2 Of course, many more actors may matter. Tarrow and Tilly (2006: 71) for instance, reproduce a diagram from Pierre Favre's La Manifestation (1990) showing a vast array of actors influencing contention in a single contentious arena. 
for whom state activity both accomplishes something immediate and sends a signal about the future of the struggle. Activists may be intimidated by repression, but may also see signs of state weakness or clues about what strategic shifts might produce greater results. They also pay attention to the impact of repression on bystander populations. Bystanders constitute the second player, representing both organized and unorganized people not initially involved in a contentious exchange (though they may have some sympathy in one direction or the other). The third players are factions inside the state, composed of people who may worry about their position or survival (particularly when the regime seems unstable) or may have some sympathy with reform goals. Such groups can pursue the greater good of a stable and just society, their own private interests, or some vision of the future that serves both. While some define the politics of state factions as somehow fixed and distinctive, I view those politics as emergent and relational.

While I here describe the activity of "bystanders" or "state factions" as if they were singular collectivities, a fully developed picture would render them in complex and multiple terms. All manner of bystanders typically exist, and among them an act of state repression or reform may elicit a variety or responses. Bystanders also react to one another, creating groundswells in support of, say, human rights or a state move to eradicate drug dealers. Similarly, state factions constantly eye one another and seldom move against the established order without some indication that they'll have company. Here too we find a plurality of players, interacting rather than acting. Still, for the sake of relating interactions among players to issues of context and strategic decisions, I will map the interplay of only the four main players mentioned above.

I will call the primary targets of state repression movement activists, although of course all manner of unorganized bystanders are inaccurately accused of subversive action or affiliation under dictatorships. Still, let us for the moment leave these people to the side and consider the options open to activists caught up in contentious struggle with authorities. Such activists, facing state repression, must make two calculations. First, do they expect to engage with authorities in isolation, or do they have some expectation of recruiting broader political support? Second, in light of this first question, should they respond with stronger resistance or with conciliation and moderation?

Activists without any real hope of support need to make what is essentially a power politics calculation. If help will not come from some other quarter, their response to state activity depends on how many resources they 
can muster within their own network, and whether they expect to make headway in a head-to-head struggle with the state. Isolated movements with strong support may envision a way forward via more militant confrontation without recruiting bystander support, and may escalate unarmed protests into armed struggle; without such support, the movement may seem clearly overmatched, and so capitulate. On the other hand, movements more firmly embedded in potentially supporting social networks can think about expanding their power both by finding common cause with others and by conducting themselves in ways that generate sympathy. Militant or armed attacks on state targets may seem to assert movement capacity, but alienate potential supporters. A strategy that inspires strong state violence against movements in isolation may deplete the ranks, and absent a strong movement response, may make the movement seem incapable and doomed. A strategy that draws strong repression down on movements with many potential supporters (particularly if the movement has successfully asserted the worthiness of its demands and reasonableness of its tactics) may trigger a cascade of solidarity that is much more important than what it might accomplish by stronger militancy alone. In both cases, the advantages of militancy and moderation depend on the availability and likelihood of solidarity and social support.

Bystanders respond to state violence in various ways. They may be cowed by it - driven to inactivity by the display of state power, or by the apparent randomness of the attacks. They may be outraged by violence that seems to transgress political or moral norms. They may be recruited by violence - seeking, in a time of conflict, to ally themselves with the apparently most powerful combatant. Finally, they may be convinced or compelled by it - persuaded that the victims of violence behaved in ways that merited the attack. How bystander populations will react to state violence hinges on how bystanders see themselves in relation to the targets of state repression, how the security apparatus presents punishment and apprehension, and how carefully and exclusively that violence is directed against its intended targets (DeNardo, 1985). Bystander responses also reflect ideas about the relationship between activism and the established political system: is activism a necessary challenge to a closed system, a cherished bid for dignity amid degrading conditions (Wood, 2003)? A reasonable compliment to a more liberalizing order, or a threat to a system with expanding and more liberal possibilities (Rodriguez, 2012)? Bystander populations are potential recruits for either dissidents or state agencies, depending on their views of the broader political environment and the depth of their indignation at the regime. 
One of the signs that a state or regime has entered a period of crisis is that factions of that state (defined either as particular actors or the leadership of significant institutions) may take independent action, often at variance with that of the regime's inner circle (Johnston, 2012). These factions can be motivated by a variety of factors - fear of instability, a commitment to reform and democracy, ambition for power within the state, or some sense that their institutional interest or mission needs protection. State factions, in turn, can seek to shore up central rule by replacing a weak or faltering dictator; they may maneuver to bolster the dictator, and so their own position in the regime. Or they may push for stronger repressive measures in reaction to liberalization. Finally, they may reach out to social forces in a pro-democracy alliance.

A number of factors influence these decisions. Some attach to the character of the actors themselves. Strongly institutionalized or professional state agents, in particular highly professional security forces, will be inclined to defend their interests (Bellin, 2012). Others in the state will have strong ideological commitments - apt, for instance, to favor repressive moves against communists. Some decisions will reflect the overall character of the regime, with factions in patrimonial or personalistic regimes perhaps more easily motivated by fear and a desire to prop up the dictatorship than those in more bureaucratized forms of rule (Bratton and Walle, 1994). But many of these decisions are also made in light of actors' more tactical efforts to position themselves in relation to others in the field of play. Hence, in responding to some political crisis, they will ask about the kind of opposition that exists, and whether it provides the prospect of a safe future for regime defectors. Where intra-state rivalries are particularly strong, factions will pay careful attention to power balances among them, and their relative relationships to the existing political order. In putting the pieces together, we can construct the logic of these interactions by linking the influence of context, of decisions about modes of repression, and reactions to those repressive modes together.

\section{Putting the Pieces Together}

While potentially independent of each another, the four decisions that actors make about repression are typically linked. We can connect the two clearest sets of associations under the respective headings of domination and contestation represented in Table 8.1. In domination, authorities approach 
repression as a struggle with implacable enemies for control of territory or of the state. While bystander populations or civil society groups may exist, they figure only weakly in repressive calculations. In such cases, repression against subversive people (i.e., based on the identity of the target) is likely to be more intensive, less discriminate, and less fully explained - though not always secret, because knowledge about a powerful state response to challenges enhance a regime's reputation. Such targets are often politically isolated from a regime's core constituents and supporters, to whom careful explanation of violence may not seem necessary. Where physically separate from core constituents, the violence may not be particularly discriminating, but it must be more so as it moves physically closer to those constituents. Under contestation, authorities are more clearly contending with rivals and dissidents for influence over a broader and more politically significant citizenry. In such cases, repression often occurs in acts chasing down the specific perpetrators of particular proscribed acts, and will likely be less intense, more discriminate, more publicly and carefully explained. Indeed, such explanation may be as important an element of the political project as the elimination of dissent or resistance.

Table 8.1 Domination vs. Contestation

\begin{tabular}{lll}
\hline Decision & Mode 1: Domination & Mode 2: Contestation \\
\hline Targeting & Based on target identity & Based on target action \\
Intensity & Strong, draconian & Calibrated \\
Exclusivity & Depends on proximity to politically & Repression strictly limited to \\
& significant populations & designated targets \\
Publicity & Repression can be covert or & Repression is public, acknowledged \\
& acknowledged & and explained \\
\hline
\end{tabular}

These packages are broadly associated with the broader dynamics of politics in any case. We can anticipate more closed participatory settings producing repression in the domination model and places with more open participatory avenues commonly producing something that more closely resembles contestation. With fewer institutional avenues open to express grievances and scant expectations (particularly in personalistic or neo-patrimonial regimes) for equal access to those institutions, we would expect security force members to be directly involved in repression under conditions of strong state capacity, and state allies or sub-contractors more active in weaker states. Strong repression will target specific kinds of subversives for elimination, may make few distinctions between activists, sympathizers, 
and bystanders, and use excessive force and focus on projecting an image of the state as indomitable rather than (primarily) just. We would also expect repression to be most unfettered when weak regimes sub-contract it out, because such situations do not require that specialists in violence moderate battlefield calculations with the broader need to generate some national political support.

Conversely, in liberalized settings we anticipate more moderate and action based uses of repression. State agents will try to make the punishment fit the crime, to separate perpetrators from bystanders, and to explain the administration of justice. Where more democratic states have great capacity, we anticipate that they will police a fairly broad range of activity, and that the scope of policing efforts will probably diminish under weaker state administrations (Jaime-Jimenez, 1998) - although it is also possible that weak liberalizing states will undertake rules based and calibrated repression in cosmopolitan enclaves and pursue (or allow others to pursue) something more akin to domination in more remote areas; in such cases, the political consequences of provincial violence depend on the mechanisms that transmit information from the countryside to the cities. More generally, the contestation model of repression replaces a narrative of rooting out subversion with a narrative of law and order. Still, this expected association serves to highlight cases in which repression defies that trend, and seems a more obviously excessive deployment of force.

The strategic dilemmas that most interest us in this discussion exist in the middle ground of a liberalizing regime - when security forces may still seek to eliminate rivals and subversives (often by whatever means they can muster) while still claiming to be the legitimate purveyor of just coercion: justice requires some due process, security requires decisive pursuit of subversive "types," and the two goals operate at cross purposes. Authorities may try to explain away or disavow violence that clashes with emerging procedural or civil norms, or cultivate a sense of threat and danger that convinces bystanders to overlook the suspension of due process. Officials may present kinds of people (subversives) as inherently prone to modes of proscribed behavior. Repression, that is, will not always emerge as clean distinctions between our two types (domination and contestation). Indeed, in such cases the contradictory pull of these different decisions may tell us more about what's really going on.

The give and take between state authorities and challengers is only weakly structured by external conditions, and the alliances that may form during a campaign of repression are more fluid. All manner of actors in that mixed context will face dilemmas over repression. Bystander populations 
may both be opposed to violence and dictatorship, and afraid of instability or of the demands that activists make. Security force members may support civilian rule but not trust civilians to maintain public order or respect military interests. Activists may support new democratic processes but fear that they will be outspent, outmaneuvered, or outgunned during elections. In this context, we cannot be certain, in advance of a sequence of repression and response, what decisions actors will make; such decisions will be interactive and contingent. Moreover, even after taking some course of action, actors will have mixed motives and persistent fears. Regime factions who defend due process and democracy may still feel that subversives need to be rooted out. Activists who demonstrate in favor of free elections and civil liberties may still hope to provoke state violence in order to recruit social support for more militant oppositional tactics.

Consider how different repressive acts may influence bystander populations differently, and what impact bystander responses have on others. The decision to start with bystander reactions is not arbitrary: authoritarian states often undertake liberalizing reforms explicitly to direct social support away from more radical reformers, and so direct reforms to achieve consequences among bystanders. Repressive acts will disturb such bystanders when they are (1) at variance with the emerging liberal norms, and (2) insufficiently justified as somehow necessary despite their anti-liberal character. While I cannot here claim to judge the likely bystander reaction to all modes of repression, I can start with our two polar categories of domination and contestation, and assume that domination will more likely trigger bystander anger and sympathy for the targets of repression, while contestation will likely trigger less outrage and perhaps even acquiescence. Taking authoritarian decisions about how to repress as exogenous to the theory, then, what do we anticipate in terms of social reaction?

Beginning with an act of repression, bystander populations can either react to the violation of liberal norms, and express support for targeted activists, express appreciation for regime action against social threats, or simply retreat from any significant response.

Depending on bystander response, both activists and state factions will make their moves. An influx of bystander support to the movement may allow activists to be more politically assertive, but also encourages the adoption of movement tactics that demonstrate adherence to broad liberal and democratic norms - i.e., explicit non-violence, and perhaps an emphasis of processual as opposed to sharply redistributive claims. On the regime side, the spectacle of massive social sympathy for the victims of state repression, or expressions of anger at government violations of liberal 
norms, can drive some factions into moderating postures in relationship to core regime elements. This sequence represents a classic anti-repression coalition, often important in pushing a liberalizing regime toward a fuller transition.

The opposite trajectory occurs when bystanders do not break for the regime, but either support government policing (as repression comes to be identified as a police or security action) or take little to no action. Absent popular support for activists, the movement will likely fall back on smaller and more clandestine modes of struggle, and may radicalize tactically: without an expanding popular base to constrain political choices, activists can be expected to drift toward instrumental and more violent tactics, rather than more open and peaceful demonstrations of the popular will. On the regime side, repression will likely be seen as justified politically and in security terms; at minimum, the social and political costs of repression may seem reduced. Consequently, we anticipate little change in the regime, or even growing support for more repressive responses to dissent and opposition. However, little incentive exists in these interactions to moderate the relations between the regime and activists.

What is illustrated is the basic point that repression, whatever effect it produces on its primary targets, exerts broader political and social influence. Activists may suffer terrible losses to repression, but may also reap great political benefits from those losses. Conversely, activists who avoid state repression may, in consequence of their easy survival, attract less sympathy or support. Repression has both targets and audiences, and the key consequence of state violence often depends on audience reaction more than on target survival or surrender.

Liberalizing authoritarian orders, as we have seen, provoke additional dilemmas. State actors, for instance, must acknowledge and publicly conform to liberal norms despite their security fears. Hence, they may supplement patterns of violence generally in line with the contestation model with repression that targets specific people for intense, often lethal violence. This mode of violence combines decisions we have associated with the contestation and the domination models - and undertakes to repress in a context of a more widely advertised move in the directions of the rule of law. Similar hybrid tactics may emerge in activist engagement with the state - so that public demonstrations for democracy co-exist with more violent strikes at the regime, conducted in secret. Hence, while analysts have sought to explain increases in violence during regime transitions in terms of weak institutions, communal security dilemmas, and a new 
leader's attempt to generate support through violent nationalist appeals, we have identified another source of that violence: a disjunction between the liberal norms embodied in democratic aspirations (and the democratic avowals of those wishing to secure a place for themselves in an emerging democratic order) and the persistently sharp, often existential animosity that may still separate different forces in society.

\section{Conclusion}

We are not positioned to resolve the dilemmas that dictators face in the complicated setting of liberalization - because fluidity represents an essential part of the context. Dilemmas are just that, dilemmas. Nor, of course, has this discussion exhausted the possibilities of what we anticipate happening. But thinking about repression as both having an instrumental and a public aspect, and considering repressive acts in connection to the four big decisions we have discussed seems like a path toward better understanding.

Other questions remain. We have considered exclusivity decisions, for example, as simply a matter of tactical design - but they clearly also have something to do with context. Whether a repressive force can calibrate and focus violence on specific targets will depend on their will to do so, but also on how isolated those targets are from bystanders. Isolation is both a physical and an associational matter. The levels and kinds of solidarities in society will therefore also help explain how likely an isolated act of repression will be to incite spillover, either as collateral damage or solidarity. The secrecy of ad hominem repression in liberalizing states - the assassinations and disappearances that often occur alongside new elections or the roll-out of more open state institutions - certainly involves security force decisions to act in secret, but is aided and abetted by situations in which other members of society feel disconnected (demographically, geographically, or politically) from those victims. Secret killings are not simply discovered - they must be publicized and so require willing publicists.

Much remains to be done to unpack these issues. I hope I have demonstrated that a way of looking at the interplay between repression, audience, and context can represent a fruitful entry point to some persistent and thorny questions about authoritarian violence in liberalizing settings. Whether I've succeeded or not depends on how the program gets carried forward from here. 


\section{References}

Anderson, Benedict. 1990. "Murder and Progress in Modern Siam." New Left Review 181: 33-48. Beetham, David. 1991. The Legitimation of Power. Atlantic Heights, NJ:Humanities Press International. Bellin, Eva. 2012. "Reconsidering the Robustness of Authoritarianism in the Middle East: Lessons from the Arab Spring." Comparative Politics 44: 127-149.

Bonner, Michelle D. 2009. "State Discourses, Police Violence and Democratisation in Argentina." Bulletin of Latin American Research 28: 227-245.

Boudreau, Vince. 1996. "Northern Theory, Southern Protest: Opportunity Structure Analysis in Cross National Perspective.” Mobilization 1: 175-189.

-. 2009. "Repression and the Making of Underground Resistance." In Rosanne Rutten, ed., Brokering a Revolution: Cadres in a Philippine Insurgency. Quezon City: Ateneo de Manila University Press.

Boykoff, Jules. 2007. “Limiting Dissent: The Mechanisms of State Repression in the USA.” Social Movement Studies 6: 281-310.

Bratton, Michael, and Nicolas Van de Walle. 1994. "Neopatrimonial Regimes and Political Transitions in Africa." World Politics 46: 453-489.

Carey, Sabine C. 2006. "The Dynamic Relationship between Protest and Repression." Political Research Quarterly 59:1-11.

Curaming, Rommel A. 2013. "The End of an Illusion: The Mendiola Massacre and Political Transition in Post-Marcos Philippines." In N. Ganesan and Sung Chull Kim, eds., State Violence in East Asia. Lexington: University of Kentucky Press.

Davenport, Christian. 1995. “Multi-Dimensional Threat Perception and State Repression: An Inquiry into Why States Apply Negative Sanctions." American Journal of Political Science 39: 683-713.

DeNardo, James. 1985. Power in Numbers: The Political Strategy of Protest and Rebellion. Princeton: Princeton University Press.

Earl, Jennifer. 2003. "Tanks, Tear Gas, and Taxes: Toward a Theory of Movement Repression." Sociological Theory 21: 44-68.

—. 2011. "Political Repression: Iron Fists, Velvet Gloves, and Diffuse Control." Annual Review of Sociology 37: 261-284.

Favre, Pierre, ed. 1990. La Manifestation. Paris: Presses de la Fondation Nationale des Sciences Politiques.

Fein, Helen. 1995. "More Murder in the Middle: Life-Integrity Violations and Democracy in the World, 1987." Human Rights Quarterly 17: 170-191.

Francisco, Ronald A. 2005. “The Dictator's Dilemma." In Christian Davenport, Hank Johnson, Carol Mueller, eds., Repression and Mobilization. Minneapolis: University of Minnesota Press.

Gamson, William A. 1975. The Strategy of Social Protest. Homewood, IL: Dorsey Press.

Gilley, Bruce. 2006. "The Determinants of State Legitimacy: Results for 72 Countries." International Political Science Review / Revue Internationale de Science Politique 27: 47-71.

Goldstein, Daniel M. 2003. "In Our Own Hands': Lynching, Justice, and the Law in Bolivia." American Ethnologist 30: 22-43.

Gurr, Ted R., and Mark I. Lichbach. 1986. "Forecasting Internal Conflict: A Competitive Evaluation of Empirical Theories." Comparative Political Studies 19: 3-38.

Haberkorn, Tyrell. 2013. "Getting Away with Murder in Thailand: State Violence and Impunity in Phatthalung." In N. Ganesan and Sung Chull Kim, eds., State Violence in East Asia. Lexington: University of Kentucky Press.

Huber, Evelyne, Dietrich Rueschemeyer, and John D. Stephens. 1997. "The Paradoxes of Contemporary Democracy: Formal, Participatory, and Social Dimensions." Comparative Politics 29:323-342. 
Jaime-Jimenez, Oscar. 1998. "The Policing of Social Protest in Spain: From Dictatorship to Democracy." In Donatella della Porta, and Herbert Reiter, eds., Policing Protest: The Control ofMass Demonstrations in Western Democracies. Minneapolis: University of Minnesota Press.

Jasper, James M. 2006. Getting Your Way: Strategic Dilemmas in the Real World. Chicago: University of Chicago Press

Jenkin, Craig, Lindsey Peterson, and Katherine Meyer. 2008. "The Politics of Dissent and Repression: How Regime Structures Shape Protest/Violence Cycles.” Paper presented at the International Studies Association Convention, San Francisco, CA, 27 March.

Johnston, Hank. 2012. "State Violence and Oppositional Protest in High-Capacity Authoritarian Regimes." International Journal of Conflict and Violence 6: 55-74.

Kirschke, Linda. 200o. "Informal Repression, Zero-Sum Politics and Late Third Wave Transitions.” The Journal of Modern African Studies 38: 383-405.

Kowalewski, David, and Dean Hoover. 1992. "Dynamic Models of Dissent and Repression." Journal of Conflict Resolution 36.1: 150-182.

Lindekilde, Lasse. 2012. "Neo-liberal Governing of "Radicals": Danish Radicalization Prevention Policies and Potential Iatrogenic Effects." International Journal of Conflict and Violence 6:109-125.

Mansfield, Edward D., and Jack Snyder. 2002. "Incomplete Democratization and the Outbreak of Military Disputes." International Studies Quarterly 46: 529-549.

Migdal, Joel S. 1988. Strong Societies and Weak States: State-Society Relations and State Capabilities in the Third World. Princeton: Princeton University Press.

Nathan, Andrew J., Perry Link, Orville Schell, and Liang Zhang. 2001. The Tiananmen Papers. New York: Public Affairs Press.

Oberschall, Anthony. 1973. Social Conflict and SocialMovements. Englewood Cliffs, NJ: Prentice-Hall.

Ondetti Gabriel. 2006. "Repression, Opportunity, and Protest: Explaining the Takeoff of Brazil's Landless Movement." Latin American Politics \& Society 48: 61-94.

Rodriguez, Dylan. 2012. "Beyond "Police Brutality”: Racist State Violence and the University of California.” American Quarterly 64: 303-313.

Roessler, Philip G. 2005. "Donor-Induced Democratization and the Privatization of State Violence in Kenya and Rwanda." Comparative Politics 37: 207-227.

Savun, Burcu, and Daniel C. Tirone. 2011. "Foreign Aid, Democratization, and Civil Conflict: How Does Democracy Aid Affect Civil Conflict?” American Journal of Political Science 55: 233-246.

Tankebe Justice. 2009. "Self-Help, Policing, and Procedural Justice: Ghanaian Vigilantism and the Rule of Law." Law \& Society Review 43: 245-270.

Tarrow, Sidney. 2012. Strangers at the Gate: Movements and States in Contentious Politics. New York: Cambridge University Press.

Tilly, Charles. 200o. "Processes and Mechanisms of Democratization." Sociological Theory 18: 1-16.

- 2001. "Mechanisms in Political Processes." Annual Review of Political Science 4: 21-41.

- 2003. The Politics of Collective Violence. New York: Cambridge University Press.

Tilly, Charles, and Sidney Tarrow. 20o6. Contentious Politics. New York: Oxford University Press. Touraine, Alain. 1985. "An Introduction to the Study of Social Movements." Social Research 52: 749-787.

Wood, Elisabeth J. 2003. Insurgent Collective Action and Civil War in El Salvador. Cambridge: Cambridge University Press.

Wood, Leslie J. 2007. "Breaking the Wave: Repression, Identity, and Seattle Tactics.” Mobilization 12: 377-388. 

Part 3

International Arenas 



\title{
9 The United Nations
}

\author{
Gay versus Anti-Gay Players in Transnational Contention
}

\section{Clifford Bob}

Conflict over gay rights has been a key battleground in America's culture wars for decades. Although much of the social science literature focuses on the gay rights movement, there is of course a powerful rival: a movement of social conservatives that has played a strong role as the conflict has swirled across local, state, and national arenas. Less well known, the conflict is international. There are parallel battles over gay rights in other states, and international organizations are heavily involved.

This chapter highlights the latter aspect of the international fight, focusing on the United Nations. ${ }^{1}$ Although the UN does not issue binding international law, its policies have considerable symbolic value and real political influence. With its universal membership and broad policy ambit, the $\mathrm{UN}$ is not representative of most international organizations. However, its importance in international affairs justifies examining it here, as a key example of how international organizations act as arenas.

In the UN, two "compound players" clash with one another: a transnational network of gay rights proponents; and its foe, a transnational network of traditional religious believers. Like other compound players, both networks include diverse organizational and individual components, in this case foundations, media, individuals, and sometimes governmental officials. At moments when policy decisions are made, having such officials in a network is often of great importance. But the most constant members of the two rival networks are non-governmental organizations (NGOs), acting as steady advocates for or against gay rights. As with other compound players, the members of each network sometimes work together but more frequently act autonomously, albeit with broadly shared goals. In addition, they often compete with one another for members, resources, and influence, part of the general competition for organizational survival critical to every NGO (Bob, 2005). For this reason, in this chapter I focus

1 This chapter is based on research conducted for my book, The Global Right Wing and the Clash of World Politics (Bob, 2012), and the empirical section draws heavily from that book. The Global Right Wing also includes a chapter analyzing transnationalized clashes over gay rights in Sweden and Romania. 
most of my attention on the NGOs within each network, treating them as the primary "players." In addition, rather than highlighting conflict within the networks, I devote this chapter to exploring how the NGO players in each promote their goals in the UN arena. As will become clear, in addition to examining affirmative strategies, I pay particular attention to ways in which the players seek to advance their goals by undermining players in the rival network.

The following section briefly describes the UN as an "arena." Next, I analyze how the gay and anti-gay rights networks conflict with one another using a variety of strategies and exploiting institutional characteristics of the UN arena. In the conclusion, I draw out broader implications of using the players and arenas approach, particularly in the common situation that rival players clash with one another.

\section{The UN Arena}

As an arena, the UN has several characteristics which it shares with other international organizations and to some extent with other types of arenas. First, it is fundamentally an arena composed of players (member states) who at least in theory and often in fact control its operations, decisions, and policies. Usually this is done through consensus procedures or, in some cases, majority voting by states. In addition, other entities, particularly NGOs, may act as players, seeking to influence states and the UN bureaucracy. NGOs may gain two forms of formal UN recognition, consultative or roster status, allowing them easy access to the UN but no voting privileges. Additionally or alternatively, they may influence the UN from outside, by generating public pressure, influencing states in other arenas, or other means. Frequently too, NGOs, as well as states, become parts of larger advocacy networks on particular issues. These networks are loosely tied compound players that act not only in the UN but also in other arenas, where developments may then be used to promote goals back in the UN.

Second, like many other arenas and particularly like other international organizations, the UN includes a number of discrete but inter-related subarenas of varying power and importance. These offer a variety of sites in which players contend and interact with one another. Even the weaker subarenas sometimes offer considerable possibilities for states, NGOs, or others to advance political agendas. At the UN, these sub-arenas include wellknown organs such as the Security Council, General Assembly, Secretariat 
and Economic and Social Council (ECOSOC); specialized bureaucracies and quasi-judicial entities within these organs, such as ECOSOC's Human Rights Council or the Secretariat's Department of Disarmament Affairs; and allied organizations such as the Food and Agriculture Organization or World Health Organization.

Third, within each of these sub-arenas, players' capabilities vary, depending not only on their resources but also on the rules of the sub-arena. For instance, in the UN General Assembly, every country receives an equal vote, whereas in the Security Council, the five permanent members (the world's most powerful nations at the UN's founding in 1945) each may exercise a veto over decisions. Fourth, UN bureaucracies exercise considerable autonomy in issuing recommendations and distributing resources, notwithstanding ultimate oversight by member states. On many issues, state opinions are divided, offering UN officials the ability to act as players - that is, as advocates for policies that the UN might adopt. The Secretary-General is the most important example of this, but at every level of UN officialdom, agencies and individuals can and do act as players. Frequently too they become informal members of the advocacy networks noted above. The broader point is that the UN is far from a neutral arena; it is intrinsically and simultaneously composed of players.

\section{Gay Rights Players}

International gay activism began as early as the mid-1970s in conjunction with a global rise in "rights culture." As policies toward homosexuals improved within states, particularly in northern Europe and parts of the Americas, gay groups began working overseas and in international arenas such as the UN. A key player was the International Lesbian and Gay Association (ILGA). Founded in 1978 and headquartered in Brussels, by 2010 ILGA included over 670 NGOs from over 110 countries. (As such, like many of the compound players discussed in this chapter, ILGA is also an arena.) Coordinating transnational advocacy and supporting national campaigns, ILGA conducts research, publishes reports, and holds conferences. At the UN, it alerts local members about relevant policies, encourages home state lobbying, and facilitates members' participation.

The International Gay and Lesbian Human Rights Commission (IGL$\mathrm{HRC}$ ) is another major player. Begun in 1990 as a one-room office on San Francisco's Castro Street, by 2008 the group had annual revenues over \$1.7 million and 18 staff in New York, Buenos Aires, and Capetown. With a 
primary goal of improving gay rights worldwide, IGLHRC helps gay communities facing attack, builds the capacity of local partners, and works for policy change at the UN.

More recent additions to the gay network include Amnesty International and Human Rights Watch. For years starting in the late 1970s, both of these major rights NGOs had rejected overtures by homosexual activists. At the time, gay rights were deemed beyond the NGOs' missions and too political. Only in the mid-1990s, after years of discussion, conflict, and pressure, did both groups open new and important programs on sexual rights.

Finally, the gay rights movement includes several major underwriters. Through the 1990s, the Ford Foundation provided much of the money, both for American groups such as IGLHRC and for overseas clients. For European NGOs such as ILGA, the European Union and member governments were major funders. Since 2000, the Arcus Foundation of Kalamazoo, Michigan, and New York City has also become a key supporter of gay activism worldwide.

Why did these and other groups enter the global arena? The decision came only after substantial debate within each player, but a number of factors played a role. First, gay activists, who hail primarily from countries with the most robust rights, seek to backstop domestic gains. In recent years, the UN bureaucracy has generally favored gay rights - indeed, some officials have become gay rights players - even as some member states remain hostile. Just as important is the "quest for recognition" of gay lifestyles (ILGA, 2006). In this, even failures to create new norms or treaties can be useful if they energize broader constituencies. Finally, advocates lobby for international agreements to pressure countries where rights are limited or societal violence rampant.

\section{Anti-Gay Rights Players}

As gay players entered the international sphere, religious conservatives opted to play there as well. This occurred despite the fact that some of these organizations have long held the UN in low repute. Given the power, symbolic if nothing else, of the UN, however, the religious groups ultimately came to believe that failing to use the UN would hurt their cause. Having made that decision, many of them have become skilled players, often specializing in efforts to block or derail initiatives of gay players.

Their primary stated goal is preserving "traditional" or "natural" families against the "gendered" family, the concept of "sexual orientation," and 
"homosexual rights." The network is a compound player, spanning governments, especially socially conservative Islamic, African, and Caribbean nations, as well as the Holy See, which enjoys special status at the UN. Again, however, the most focused participants in the debate are NGOs, most identified with various Christian denominations and most active in a variety of related "family" issues.

A major intellectual and organizational hub is the Howard Center for Family, Religion and Society based in Rockford, Illinois. Founded in 1976, the center's mission is to "defend" the "natural family," "the fundamental unit of society, not the individual, not the state, not the church, and not the corporation" (Howard Center, 2010). The Center and its biennial World Congress of Families (WCF) have thousands of individual members and 27 partner organizations. Based in the Americas and Europe, with partners such as Focus on the Family, Real Women of Canada, Red Familia (Mexico), and United Families International, WCF members have played central roles in national and international debates over "family" issues.

The Catholic Family \& Human Rights Institute (C-FAM), founded in 1997, is another key player (and WCF member). Guided by "fidelity to the teachings of the Church," C-FAM works to protect the "natural family" by "discrediting socially radical policies" such as recognition of same-sex marriage and even the "sexual orientation" concept itself (C-FAM, 2010). To reach these goals, C-FAM monitors and lobbies international institutions, particularly the UN, involving itself in everything from regular UN meetings to international conferences to treaty negotiations.

\section{UN-Closeting Gay Rights}

Given the vehemence of this opposition, gay advocates long avoided a frontal assault on the human rights citadel. Much though they might have preferred an international convention or declaration on gay rights, they were realistic about its dim prospects and took a more modest approach. First, they initially promoted international recognition of the "sexual orientation" and "gender identity" concepts, rather than seek the broader goal of gay rights. Second, they worked to expand interpretation of existing rights to include, implicitly, rights for homosexuals. They also chose to mount both efforts in low-level UN sub-arenas - conferences, quasi-judicial commissions, treaty monitoring bodies, and expert committees where incremental steps might be taken with less chance of raising opposition. The goal was new "norms" or "soft law" - declarations, publications, or rulings lacking the governmental 
ratification necessary for international treaties or conventions. Through frequent citation and usage, such statements might nonetheless form the basis for more comprehensive and enforceable "hard law" sometime in the future. Yet, as we shall see, even these closeted approaches drew fire.

The strategy's first step was wooing potential allies, often at international conferences. These have been a staple UN sub-arena in many issues. They are usually of brief duration but often proclaim non-binding but symbolically important declarations or statements. As early as the 1975 UN Conference on Women in Mexico City, an International Lesbian Caucus formed ties with feminist delegates. Gay rights groups were also active at UN conferences in the 1980 s and 1990s, gaining accreditation, making public statements, and winning occasional delegates to the cause. In these venues, gay concerns did not make it explicitly into UN documents. However, vague but potentially inclusive language favored by homosexual advocates sometimes did. For instance, in 1995 the Platform for Action of the Beijing Women's conference declared that women should "have control over ... their sexuality, including sexual and reproductive health" - although it also omitted four proposed references to "sexual orientation" (UN, 1995: Para. 96).

In 2003, Brazil introduced a resolution at another low-level sub-arena, the UN Human Rights Commission within ECOSOC, stating that the "enjoyment" of universal human rights should not be "hindered in any way on the grounds of sexual orientation" (UN, 2003: 1). As discussed below, this resolution drew fierce opposition, failed to garner majority support, and was later withdrawn. More prominently, in the UN General Assembly in late 2008, France introduced a statement (requiring no vote) urging that states "commit to promote and protect the human rights of all persons, regardless of sexual orientation or gender identity" (UN, 2008: 1). Joined by 66 states, the statement also drew vehement opposition led by Syria, speaking for the Organisation of the Islamic Conference (now Organization of Islamic Cooperation) (OIC) in a counterstatement signed by 57 states.

Outside the UN, one related effort to build "soft law" is worth noting. In 2006, two NGOs favoring gay rights, International Service for Human Rights and the International Commission of Jurists, gathered a distinguished and sympathetic set of experts to draft the Yogyakarta Principles. These claim to be "a universal guide to human rights which affirm binding international legal standards with which all States must comply" (ISHR and ICJ, 2006). Among the 29 principles and hundreds of directives, Yogyakarta holds that states must "embody ... equality and non-discrimination on the basis of sexual orientation and gender identity" in their constitutions or laws and must "ensure" that "freedom of opinion and expression" does not violate the 
"rights and freedoms of persons of diverse sexual orientations and gender identities" (ISHR and ICJ, 2006: Prins. 2, 3, 19). Since their promulgation, the Principles have repeatedly been cited by gay rights players - and denounced by foes - in the UN and other arenas.

In sum, gay activists at the UN have a mixed record. They have won new governmental backing for their cause. Most of these allies support the concepts of "sexual orientation" and "gay rights" - and both ideas are far better known internationally than decades ago. But the UN as a body has not recognized gay rights, and even the concept of sexual orientation remains controversial there. As we shall see, conflict envelops an array of issues, from process to participation to substance.

\section{Protesting Process}

Opposition begins with denunciations of rights advocates' core strategies. Far from accepting or overlooking incremental methods in low-level UN sub-arenas, religious conservatives disparage them as "an attempt by activists to present an aspirational, radical social policy vision as a binding norm" (Tozzi, 2007: 1). In this view, lobbying in obscure UN forums and grafting existing international treaties onto new issues are nothing more than cunning "maneuver[s]" to "by-pass ratification and avoid ... confrontations" with states having "contrary ... national cultures and religious values" (Women for Faith \& Family, 1999). Even the more open strategy pioneered by the 2003 Brazilian resolution provokes critique, less as to process than the uses to which such non-binding statements might be put. In this view, UN "soft law" has no legal value even if "dishonest" activists improperly exploit self-constructed "norms" to bootstrap their causes forward (Sylva and Yoshihara, 2007: 19).

But conservatives have learned that seeking to delegitimize "soft law" after the fact - or lambasting international institutions themselves - leaves them on the defensive. Faced with the threat that "international norms are beginning to shape the content of domestic law ... [and] being used to deconstruct long-standing notions of family life," conservative players are now engaging "in efforts to avoid negative outcomes and promote positive ones" (Wilkins, 2007: 370). As we shall see, part of this involves fighting all aspects of gay rights initiatives at the UN. In addition, conservative groups use UN sub-arenas preemptively, to construct and strengthen their own rival norms. A key example occurred in 2004 when conservative activists, working with Qatar, hosted their own international conference, endorsed 
beforehand by a UN resolution. The conference resulted in the Doha Declaration, affirming the "right of men and women" only to marry and the family as the "natural and fundamental group unit of society ... entitled to protection by society and the State" (2004). In short, the Doha sub-arena created a direct competitor to the "soft law" produced by women's and gay rights groups at their own conferences. This made it more difficult to distinguish which of many competing statements in fact constituted a "new" norm. As one activist boasted, the Doha Conference and Declaration "take their place in the canon of declarations, platforms, and agendas from which international legal norms are derived by political leaders, judges, and lawyers" (Wilkins, 2007: 370).

\section{Excluding and Expelling Players}

No gay groups appear to have attended the Doha conference, making for a harmonious meeting. By contrast, most UN events on these issues are riven by conflict. Although conservative players often object to the processes and outcomes, they today participate as gamely as their adversaries. Indeed, the rival networks follow parallel tactics aimed at gaining advantage over one another. These begin with efforts to restrict their opponents' participation in the UN. For activist groups, a key step to a formal if weak UN role is ECOSOC consultative status. In theory, gaining it is a routine matter, involving a brief application, perfunctory screening, and long-term status. Yet when it comes to homosexuality and other controversial issues, even the threshold question - Who participates? - draws fire.

In 1993, ILGA applied for and obtained consultative status, a historic moment for its members. ${ }^{2}$ But jubilation soon turned to tribulation as Christian soldiers took to the warpath in two other arenas, the US Congress and broader American society. Their battle cry, bellowed in fundraising letters and blasted on prime-time news: ILGA must be ousted because its network included a pedophilia peddler, the North American Man Boy Love Association (NAMBLA).

Within months, Congress unanimously passed a law withholding \$119 million from the UN pending presidential certification that the UN accredited no organizations promoting pedophilia. President Bill Clinton hastily signed the bill into law. 
The effect on ILGA was traumatic - as gleefully expected by conservatives who gloated over its coming "bind": "If it kicks out NAMBLA, it's hypocritical, if not it supports sex between boys and men!" (The Report, quoted in Gamson, 1997: 183-184). Unsurprisingly (except to NAMBLA), ILGA engaged in intense internal debate over NAMBLA's membership. In June 1994, ILGA expelled NAMBLA and two other groups. In addition, ILGA changed its membership procedures. Within two years, it implemented a tough, four-step screening process to ensure that no group like NAMBLA would be admitted in the future. Most fundamentally, key members of the homosexual community redefined the very boundaries of gay identity, with America's largest advocacy group, the Human Rights Campaign Fund, bluntly stating, "NAMBLA is not a gay organization" (King, quoted in Gamson, 1997: 179, 185).

Despite all this, ECOSOC suspended ILGA in September 1994. The group had neglected to rid itself of a small German NGO that promoted decriminalization of pedophilia. Too late, ILGA re-emphasized its new identity by throwing out the Germans. It then waited five years to reapply for consultative status but was repeatedly rejected based on the earlier scandal. Tarred with the same feather, other players such as IGLHRC were harried at UN conferences. Only in 2006 did ECOSOC finally grant consultative status to ILGA-Europe.

Such efforts to exclude players from the UN, with their serious effects on gay groups' structures, rules, and identities, are not exclusive to conservatives. Gay advocates have followed similar approaches, though without such signal successes. Human Rights Watch has griped that foes such as C-FAM "oppose the U.N. and all international human rights mechanisms" (Human Rights Watch, 2005: 84). The implication seems clear: such NGOs do not deserve consultative status and should play no role in the arena. In related cases, this has in fact come to pass. In the early 1990s, Human Life International's (HLI) application failed due to its "hostil[ity] to a whole field of UN activity," family planning (Willetts, 1996: 4, 37). After C-FAM's UN acceptance, it too faced accusations about its close relationship to HLI and alleged enmity to the UN. But these revelations, published by Catholics for a Free Choice (CFFC) (now Catholics for Choice), an NGO supporting abortion, feminism, and gay rights, failed to catch fire.

CFFC, whose own application for consultative status came under fire from the Holy See in 1998, returned the favor in 1999 after it gained accreditation. It launched its ongoing "See Change" campaign to strip Rome of its special UN status. Since 1964, the Holy See has been a "non-member state 
permanent observer" - a position unique to any religious representative. In this capacity, it enjoys most rights accorded states - far more than NGOs in consultative status. The See Change campaign aims to reduce the Vatican to NGO status, but it too has gained little traction. For its part, C-FAM launched its own countercampaign defending the Holy See's status. To date, the Vatican retains its unusual seat at the UN where it has been a leader of the conservative network on family issues.

The broader point remains, however. Key players seek to use UN arenas not only for advancing their own agendas, but also for preventing their opponents from setting foot there or by hobbling their foes at every turn. In this, even the UN's relatively undemanding entry rules can be exploited, or external pressure may be exerted to sway UN decisions.

\section{Coalition-Building - and Unbuilding}

Beyond raising participation barriers, the rival players attack one another directly at the UN. Coalition-building, a central strategy to advance one's cause by creating more powerful compound players, joins with a darker twin - undermining the enemy. As one part of this, the contending players denounce one another's networks, casting funders and other supporters in sinister light. To take one of numerous examples, C-FAM's Austin Ruse wrote in 2000 ,

[E]normous American foundations which are very radical in their world view ... put direct pressure on governments to change their laws and vote a certain way on UN resolutions. ... Their agenda is a leftist - even Marxist - agenda of what some call the "new class" who think they know better than what tradition has taught us from the dawn of time ... Specifically, they want the family to include homosexual couples, and make abortion a universally recognised "human right." (Ruse, 200o)

In addition to such rhetorical swipes, conservatives labor to undermine opposition players directly. For instance, to deter developing countries from joining with "radical" NGOs and European governments, they have stoked anti-colonial sentiments. More generally, they stir "the resentment that heavy-handed pushing of novel norms generates in much of the world" (C-FAM, 2010).

Of course, these coalition bashers have engaged in their own networking. Most strikingly, even as they decry gay groups' dependence on "socialist" 
governments, conservative protestants and Catholics have joined with conservative Islamic states to form a kind of "Baptist-burqa" coalition. Forged in the fires of the 1990s UN women's conferences, this compound player has endured for years. Indeed, C-FAM has urged formation of a "permanent UN pro-family bloc," predicting that "our victory will come" from this "potent alliance between Catholic and Muslim countries, ... new in the world, new to history," what "[o]ur enemies call ... an un-holy alliance" (Ruse, 1999).

But again, building these ties is only half the story. Gay advocates have worked hard to impugn them. Human Rights Watch (HRW) has highlighted the "irony" of the "odd alliance" between Christian conservatives and repressive Muslim states such as Egypt (Human Rights Watch, 2005: 83-84). Together the coalition "open[s] space for attacking human rights principles themselves - as not universal but 'foreign,' as not protectors of diversity but threats to sovereignty, and as carriers of cultural perversion" (Human Rights Watch, 2005: 71). Such rhetoric may inflame HRW's constituents, but probably has little effect on its foes. More vexingly for conservative players, however, the network has suffered costly "defections," as the gay rights activists have expanded their work to multiple arenas simultaneously (C-FAM, 2010). Even in Catholic majority countries in southern Europe and Latin America, the gay rights movements has advanced, often with the support of ILGA, IGLHRC, or various organs of the European Union and Council of Europe. In turn, these countries become advocates for gay rights at the UN.

In sum, attacks on the composition of enemy players are powerful weapons in activist arsenals. At times, the volleys have their effects, forcing changes in players' structures, strategies, and even identities. Even when that does not occur, players are forced to devote scarce resources to defending themselves, thereby weakening their more affirmative actions.

\section{Sexual Orientation - or Disorientation?}

Beyond attacking process, participation, and partnering, the opposing networks clash over substance, deploying rival authorities to press core claims and undermine opponents. In this, the very nature of homosexuality, rights, and religion are tumbled into the crucible, forcing each side to spend precious resources fighting battles they had thought won long ago. For gay groups, "sexual orientation" is an innate if variable aspect of human nature. Supporting this view are scientific societies led by the American Psychological Association, although its shifting positions on the issue now seem to have settled into a compromise - that "nature and nurture both 
play complex roles" (APA, 2008: 2). Promoting nature with consummate certainty are moral authorities like South African Archbishop Desmond Tutu who has intoned that, just as black people were made to suffer "for something we could do nothing about - our very skins. It is the same with sexual orientation. It is a given" (Tutu, 2004).

But those opposing the "homosexual agenda" have disputed and defamed the very concepts of sexual orientation and gender identity. Against Brazil's UN resolution, for instance, United Families International (UFI) bandied a "wealth of peer reviewed social science data" claiming that homosexuality is nothing more than a "lifestyle choice," a "passing social trend," or a "fad" presenting grave "dangers" to "individuals, families, and societies" (Allred, 2005). In 2008, the OIC similarly condemned France's joint statement to the UN General Assembly supporting rights for all people regardless of sexual orientation. The Holy See also opposes, arguing that the concepts of "sexual orientation" and "gender identity" have "no recognition or clear and agreed definition in international law" (Holy See, 2008).

Gay advocates dismiss the foregoing arguments as misinterpretation, pseudo-science, or prejudice. For instance, in answer to smearing of the sexual orientation concept, HRW has urged that it be defined narrowly - "as understood in ordinary speech" (Human Rights Watch, 2005: 86). But, again, this effort takes a toll not only on gay players' resources but also on their ability to attract support.

\section{Rights: Equal or Special?}

As noted above, a central goal of gay groups is equal rights. A matter of simple justice, explicit rights protection at the UN would create legal tools helping millions. In this view, sexual orientation and gender identity should never form the basis for discrimination. For its part, the UN should lead the way toward repeal or change of biased laws and cultural attitudes.

For conservatives, however, the idea that same-sex attraction, let alone marriage, should be acknowledged as a right is anathema. Because opponents do not recognize the concept of "sexual orientation," no rights can be grounded in it. Rather, as activists argued in fighting the Brazilian resolution, claims to gay "rights" constitute "special human rights (rather than equal human rights)," aimed at protecting a behavior, indeed a perversion, rather than a status (Allred, 2005). Worse still, as the Vatican argues at the UN, purporting to make conventional marriage "juridically equivalent to radically different forms of union" will "in reality harm [marriage] and contribute to its destabilization" (Benedict, 2006). 
Whatever the merits of these arguments, there is little question that repulsing them costs gay activists scarce time and resources. More worryingly these and more personal attacks may lead to self-censorship and deter potential allies from joining publicly with the movement, weakening the gay cause at the UN.

\section{Culture: Established or Evolving?}

So even while defending bedrock empirical and normative propositions, gay groups have turned the tables, working to undermine their foes' fundamental beliefs. Most important, they have attacked "traditional" understandings of religion, whether Christian, Muslim, Hindu, or Jewish, as narrow and crabbed. As one sally, gay rights proponents parade religious liberals at UN conferences and other sub-arenas. There they directly challenge orthodox views, their presence and statements embodying more open, faith-based values. Catholics for Free Choice exemplifies this strategy at the UN.

Outside the UN, gay activists enlist players whose eminence rivals the Pope's - then deploy them to influence UN debates. In 2006, the Dalai Lama issued a statement at activists' request, opposing "violence and discrimination based on sexual orientation and gender identity and urg[ing] respect, tolerance, and the full recognition of human rights for all" (Dalai Lama, quoted in Sanders, 2006). More vocal still, Desmond Tutu has called persecution of homosexuals "every bit as unjust as that crime against humanity, apartheid" (Tutu, 2004).

Adopting a parallel but deeper strategy, the Arcus Foundation runs a program aimed at "refut[ing] beliefs that portray gay ... people as sinful and immoral," "achieving long-term change in cultural attitudes and religious institutions" and "creating a positive shift in cultural attitudes and values toward sexuality in general and GLBT ... issues in particular" (2007). If such changes occur, as they already have in certain religions and countries, this would further affect state attitudes at the UN.

\section{Outcomes}

Whether or not these long-term strategies bear fruit, the result of opposition, both state and non-governmental, has so far been non-policy at the UN. As rights scholar Jack Donnelly has observed, "[i]n the short and medium run, there is no chance of anything even close to an international consensus on even a working text for a draft declaration on the rights of homosexuals" $(2003,237)$. To date, Donnelly's prediction has held true. 
Of course, the gay movement has scored successes in Europe and the Americas, with various forms of gay rights recognized by some states, usually as a result of prolonged contestation within national arenas. But these signal victories are matched by a resurgence of attention to, enforcement of, and enlargement in sodomy laws, especially in parts of Africa, the Caribbean, and the Muslim world, again based primarily on developments within each national arena. On this basis, governments in both camps then act as players at the UN, usually in accordance with the state's decision on the issue. There, NGO members of the Baptist-burqa network eagerly support their state allies, working strategically to block gay rights or even recognition of such basic concepts as "sexual orientation" and "gender identity." Because of the UN's consensus procedures, even states that are relatively weak in capabilities have been able to succeed in this strategy. The result has been stalemate.

\section{Conclusion}

As this chapter has shown, the players and arenas perspective, by directing attention to the recurrent clash of networks, provides a useful means of understanding the battle over gay rights at the UN. Rather than highlighting only one side to the conflict and rather than seeking to identify shifting political opportunities, the approach directs attention to strategic interactions among players, as they are affected by the UN arena. As we have seen, both sides advance their goals, using both affirmative and negative tactics. In addition, they creatively and strategically play UN rules and norms, or vault into other arenas where developments may indirectly help them at the UN.

More broadly, studying conflicts among players explains far more about the development, dynamics, and outcomes of activism than can be learned by analyzing only one side. These points jibe with two existing literatures, countermovements theory in sociology and the advocacy coalition framework in policy studies. Both recognize that movements face powerful foes who are themselves movements, and both draw attention to conflict. However, they have been deployed primarily to study interactions within states, especially the United States, not transnationally. More important, the countermovements approach continues to focus primarily on one movement, typically a "progressive" one, viewing countermovements as part of the subject's "opportunity structure" (Fetner, 2008; Meyer and Staggenborg, 1996). Advocacy coalition analysts avoid this limitation but mostly discuss coalitions' contrasting 
beliefs and their direct effects on policy, rather than the ongoing process by which they conflict with one another (Sabatier and Weible, 2007).

By contrast, the approach developed in this chapter expands upon existing ways of understanding movement strategies. Players do not merely scrutinize the current political terrain for gaps, toeholds, and opportunities. They also survey government and civil society, scouting not only for allies, as the social movements literature has long noted, but also for foes. And well they should: in most cases new policy will impinge on interests and challenge values. The possibility of resistance is real, and all that is necessary for rival players to take up arms is minimal information about a nascent menace. As we have seen in this chapter, religious conservatives mobilized early on, largely in parallel to gay mobilization.

What is the effect of opposition, whether latent or real? Most basically, it influences players' initial decisions on three crucial matters: goals (conceived here as a problem/solution pair), members, and arenas. Of course, other factors both internal and external to the player enter into these decisions too, although I have not covered these here. Nor are such matters ever permanently settled. Strategic corrections are made continuously, based on interactions with other players and arenas. The "outcomes" of conflict are always provisional and temporary. However, these three points must typically be faced early, setting a tone for the future.

A first issue is whether players will seek narrow or broad goals, a matter which opposition directly affects. The more difficulty players anticipate, the narrower their construction of a problem and its solution - or the more camouflaged their portrayal of them. This does not mean that players will necessarily trim their problems and solutions in the face of opposition. But if players believe broad construction will endanger achievement of their substantive goals or maintenance of their organizations, they are likely to do so. As shown in this chapter, in the early years of activism at the UN, gay rights players, recognizing the power of opposition, portrayed their goals in narrow and veiled terms.

Reciprocally, opposition players face a decision about transforming latent into open resistance. Antagonists do not reflexively counter one another. Rather, the more threatening the problem/solution to potential opponents' interests and values, the more likely that rival players will act, often by constructing a rival problem. Its identity? As we have seen in the UN conflict over gay rights, typically it is the very solution offered by the original player - and the player itself. For the Baptist-burqa network, gay rights and even the sexual orientation concept were seen as major threats, along with the gay rights network. 
More generally, once conflict occurs, rival players will boost efforts to achieve their goals, each using the threat posed by the other as a basis for mobilizing its own. As a result, opposition will affect players' size, membership, and identity. This occurs in at least two ways. First, anticipating hostility, players make proactive decisions about how and when to build their network. Certainly, the Baptist-burqa network strengthened itself with the aim of blocking and undermining its rival in the early 1990s. Although the network is clearly a compound player, it has worked cohesively against gay rights for decades, despite major cultural differences between its members. In turn, the gay rights network redoubled its efforts to expand its membership. Second, players may be forced to react as a result of rivals' attacks aimed at unbuilding their network. ILGA's ejection of NAMBLA, under pressure from the Baptist-burqa network, exemplifies this and shows how a foe's attacks can reshape fundamental characteristics of a player.

Conflict will also affect players' decisions about which arenas to enter. Most players operate in multiple arenas, but resource constraints force them to concentrate on a few primary ones. In explaining which are chosen, the social movements literature highlights "political opportunities," emphasizing the relative openness or closure of domestic and international institutions. As an important aspect of this, opposition affects an arena's openness and a player's decision to enter. All else equal, players will work where their foes hold least sway - and avoid arenas they dominate. In the extreme, if a player finds its goals frustrated in one arena, it may move to another or establish a more friendly one. In the international conflict over gay rights, for instance, the rival networks created new sub-arenas to advance their causes and undermine their foes, with the Yogyakarta Principles and the Doha Declaration as key results.

Notwithstanding the foregoing, an opponent's foray into a hostile arena may motivate a rival player to act there, too. If, for instance, the arena is strategically crucial in a larger battle, reluctant warriors may nonetheless enter, attempting to block action, warp policy, or at least show the flag. In the gay rights case, for instance, although the UN's bureaucracy has been generally favorable to gay rights in recent years, members of the Baptistburqa network could not ignore it. The UN is too important as an arena of international policy debate and formation. In any case, both networks have found ways of exploiting the UN's norms, rules, and procedures, seeking to tilt those in their favor and against foes, with exclusion the ultimate prize.

Under fire, a targeted player has three options: ignore, rebut, or counterattack. The more threatening the attacks appear, the more likely that 
the target will respond with rebuttal or counterattack. The result may be a vortex of venom reminiscent of a close election's waning days. More generally, as McAdam, Tarrow, and Tilly argue, contention further "polarizes" warring players, often strengthening opposed identities as well (2001).

How does opposition affect outcomes? The international gay rights conflict suggests two important but often overlooked points. First, the greater the opposition, the less effective a player will be in achieving its goals. Consider the Baptist-burqa network's attacks on the legitimacy of UN processes. These have clearly undermined the gay network's ability to achieve its goals. Second, conflict between players - rather than persuasion by one set of players - will shape outcomes. As one important aspect of this, analyses which highlight the role of framing in explaining policy decisions often ignore the fact that rival players fashion and promote potent, contradictory symbols of their own. Contention over whether gay rights are "equal" or "special" and whether religious principles are fixed or evolving illustrates these clashes. Similarly, players deploy conflicting "authorities," in this chapter, for instance, on the legitimacy of the sexual orientation concept. Of course, the deployment of frames and expertise may excite the sympathetic, acting as flags to rally those who already have a generalized leaning to the position embodied in the frame or voiced by the authority. But it is unlikely that a new frame or a self-proclaimed expert will change the views of those with pre-existing antipathy to a position.

If by contrast, the analyst focuses on rival players working at odds with one another, it becomes clear that non-policy is a more likely outcome than policy. Even when opponents cannot extinguish policy making, they can often stall it. And even when delay ends, foes overtly or subtly shape the results. In some cases, their power is such that the policies produced are little more than "zombies," so devoid of content that, while "alive" on paper, they are in reality dead. Sometimes these may be revived, but often they symbolize the fact that the arena in which a player has devoted substantial energy has turned out to be false: It may hold little prospect for achieving the player's goals, despite expenditure of significant time and resources. In the international battle over gay rights, the UN is probably not a false arena. At minimum, it presents a prominent venue for promoting awareness of the issues in countries around the world. In some cases, this has doubtless incited more opposition, but in others it has likely bolstered support. Nonetheless, it remains unclear whether the UN is an arena in which gay rights players can hope to achieve their substantive goals, given the power of rival players. 


\section{References}

Allred, Lynn. 2005. "Thwarting the Anti-Family Agenda: An Eyewitness Account of the Commission on Human Rights." Meridian Magazine, 5 April. Available at: http://www. meridianmagazine.com/familywatch/040505agenda.html.

American Psychiatric Association. 2008. "Answers to Your Questions: For a Better Understanding of Sexual Orientation and Homosexuality." Available at:www.apa.org/topics/sorientation.pdf.

Arcus Foundation. 2007. "Arcus Foundation Appoints Tom Kam to Lead Program on Religion and Values." Press release, 26 February. Available at: http://www.arcusfoundation.org/pages 2/news archtemplate.cfm?ID=20.

Benedict XVI, Pope. 2006. "Address to Members of the European People's Party on the Occasion of the Study Days on Europe." Vatican website, 30 March. Available at: http://www.vatican. va/holy father/benedict xvi/speeches/2006/march/documents/hf ben-xvi spe 20060330 euparliamentariansen.html.

Bob, Clifford. 2005. The Marketing of Rebellion: Insurgents, Media, and International Activism. Cambridge: Cambridge University Press.

-.2012. The Global Right Wing and the Clash of World Politics. Cambridge: Cambridge University Press.

C-FAM. 2010. "General Assembly 'Sexual Orientation' Vote Reveals Defection by Catholic Nations." Friday Fax 13, 7 January. Available at: http://www.c-fam.org/publications/id.1549/ pub detail.asp.

Doha Declaration. 2004. Yearofthefamily.org. Available at: http://www.yearofthefamily.org/ declaration.html.

Donnelly, Jack. 2003. Universal Human Rights in Theory and Practice. Ithaca: Cornell University Press.

Fetner, Tina. 2008. How the Religious Right Shaped Lesbian and Gay Activism. Minneapolis: University of Minnesota.

Gamson, Joshua. 1997. "Messages of Exclusion: Gender, Movements, and Symbolic Boundaries," Gender and Society 11: 178-199.

Holy See. 2008. "Statement at the $633^{\text {rd }}$ Session of the General Assembly of the United Nations on the Declaration on Human Rights, Sexual Orientation and Gender Identity." Vatican website. 18 December. Available at: http://www.vatican.va/roman curia/secretariatstate/2008/documents/rc seg-st20081218 statement-sexual-orientation en.html.

Howard Center. 2010. "Frequently Asked Questions." Available at: http://www.profam.org/ THC/xthc faq.htm.

Human Rights Watch. 2005. "Anatomy of a Backlash: Sexuality and the 'Cultural' War on Human Rights." In Human Rights Watch World Report 2005. New York: Human Rights Watch.

ILGA. 2006. "Constitution." ILGA website. 13 July. Available at: http://ilga.org/ilga/en/ article/857\#CONSTITUTION.

ISHR and ICJ. 2006. "Yogyakarta Principles." Available at: http://www.yogyakartaprinciples. org/index.html.

McAdam, Doug, Sidney Tarrow, and Charles Tilly. 2001. Dynamics of Contention. Cambridge: Cambridge University Press.

Meyer, David S., and Suzanne Staggenborg. 1996. "Movements, Countermovements, and the Structure of Political Opportunity." American Journal of Sociology 101: 1628-166o.

Ruse, Austin. 1999. "Toward a Permanent United Nations Pro-Family Bloc." Paper presented at the World Congress of Families II, Geneva, Switzerland, Nov. 14-17. Available at: http://www. worldcongress.org/wcf2_spkrs/wcf2_ruse.htm. 
—. 2000. "Joyful Warrior: An Interview with Austin Ruse." Inside the Vatican, June-July. Available at: http://indigo.ie/ imr/otr-un.htm\#Austin\%2oRuse.

Sabatier, Paul, and Christopher M. Weible. 2007. "The Advocacy Coalition Framework: Innovations and Clarifications." In Paul A. Sabatier, ed., Theories of the Policy Process, $2^{\text {nd }}$ ed. Boulder: Westview Press.

Sanders, Douglas. 2006. "Getting Lesbian and Gay Issues on the International Human Rights Agenda." Human Rights Quarterly 18: 67-106.

Sylva, Douglas, and Susan Yoshihara. 2007. "Rights by Stealth: The Role of UN Human Rights Treaty Bodies in the Campaign for an International Right to Abortion." C-FAM International Organization White Paper Series No. 8.

Tozzi, Piero A. 2007. "Six Problems with the 'Yogyakarta Principles." C-FAM International Organization Briefing Paper No. 1.

Tutu, Desmond. 2004. "Homophobia Is as Unjust as That Crime against Humanity, Apartheid." Times Online, 1 July. Available at: http://www.timesonline.co.uk/tol/comment/columnists/ guest contributors/article451901.ece.

UN. 1995. "Platform for Action of the Fourth World Conference on Women." Available at: http:// www.un.org/womenwatch/daw/beijing/platform/platı.Htm.

UN. 2003. "Human Rights and Sexual Orientation." Brazilian resolution to Human Rights Commission, 17 April.

UN. 2008. "General Assembly Adopts 52 Resolutions, 6 Decisions Recommended by Third Committee on Wide Range of Human Rights, Social, Humanitarian Issues." UN website. 18 December. Available at: http://www.un.org/News/Press/docs/2008/ga10801.doc.htm.

Wilkins, Richard G. 2007. "International Law and the Family: Building on the Doha Declaration." In A. Scott Loveless and Thomas B. Holman, eds., The Family in the New Millennium. Westport, CT: Greenwood Press.

Willetts, Peter. 1996. The Conscience of the World:The Influence of Non-Governmental Organizations in the UN System. Washington, DC: Brookings Institution Press.

Women for Faith \& Family. 1999. “UN Frontline Report: UN Declares Abortion a Universal Right; 'Enforced Pregnancy' an International Crime." Voices Online Edition XIV, Spring. Available at: http://wf-f.org/UN-AndersonSp9g.html. 



\title{
Conclusion
}

\author{
Simplicity vs. Complexity in the Analysis of Social \\ Movements
}

\author{
Jack A. Goldstone
}

In the sciences, it is always the goal, in words usually attributed to Albert Einstein, to make things "as simple as possible, but no simpler." The question posed by the essays in this volume is whether, when studying social movements and revolutions, treating the state as a unitary actor is making things too simple.

Of course, the notion of the state as a unitary actor has long been debated in political science. In their now classic analysis of the Cuban Missile Crisis, Allison and Zelikow (1999) argued that seeing the state as a unitary actor facing other similar states in the international arena - the core of realist theory - was only one way to approach the state. Other perspectives included seeing the state as a complex organization with actors within the state constrained and guided by its institutional structure, and as a set of distinct political elites feuding and cooperating to generate permissible decisions.

In the study of social movements, a great deal of progress was made by the simplification of social movement dynamics to the dyadic relations between a unitary movement that sought to change state policy, and a unitary state seeking to resist changes coming from any source "outside" the institutional political system of elections, legislatures, officials and courts. In this "polity" model, put forward by Charles Tilly (1978) and adopted by distinguished scholars such as William Gamson (1975), social movements' success could be judged in terms of two levels of accomplishment: First, achieving the desired changes in policy; and second, gaining admittance to the polity, by having its agenda and supporting personnel accepted in the institutional system of elections, legislative and executive officials, and courts. While the second type of accomplishment did not immediately achieve the movement's policy goals, it was considered an important step as state policy was expected not to be so resistant to changes sought from inside the political system.

Tilly's original graphic presentation of the Polity model is shown in Figure C1. As can be seen, the "ruler and government" is a single actor, in coalition with other actors who are polity members. There is then a boundary around 
these groups, marking the difference between polity members (incumbents) and "challengers" who are outside that boundary. Coalitions may cross the boundaries among actors in various ways, but it is "the state" (ruler and government) as such that enters into coalitions with other groups; and the state is never in coalition with challengers.

\section{Figure C1 Tilly's Polity Model, Static Version}

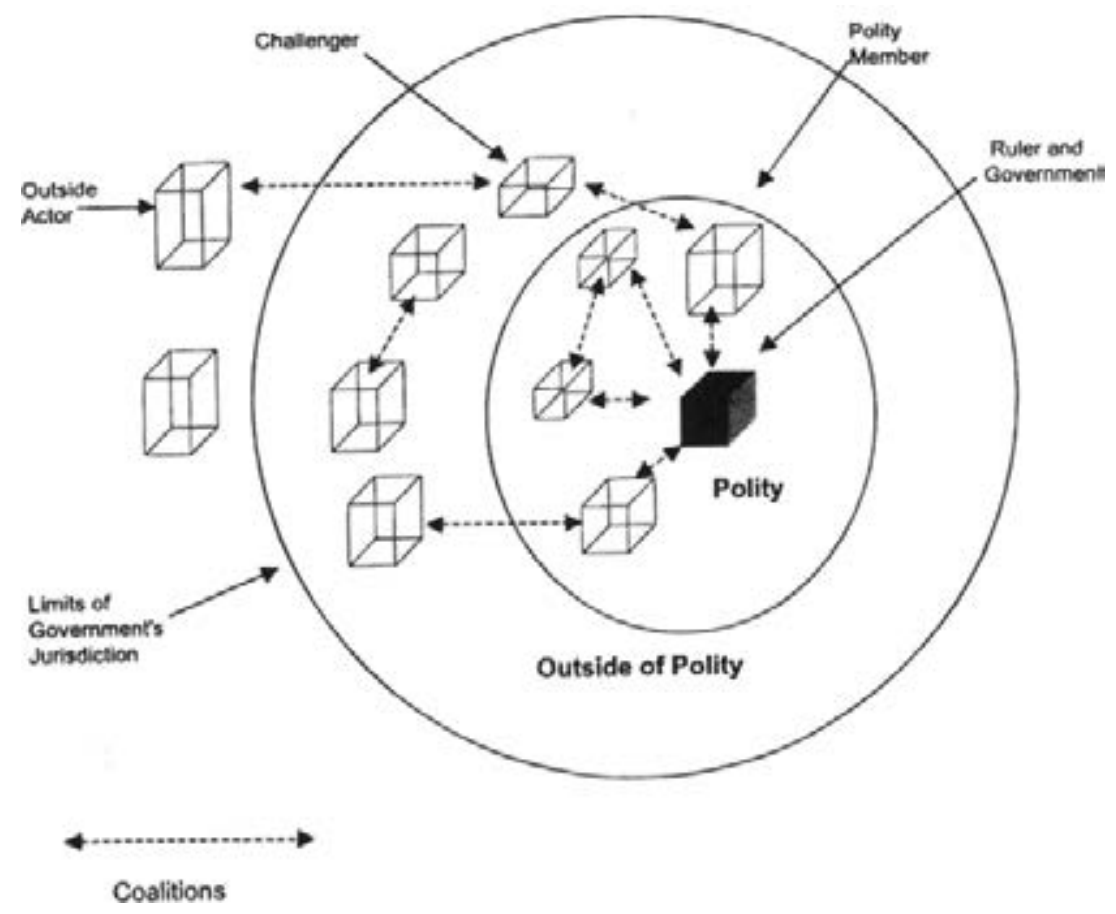

Source: Tilly 2000,5

A great deal of excellent research on social movements was done using this theoretical framework, and it continues to be useful. I have used it myself, as in the study of state-movement dynamics of repression and concessions (Goldstone and Tilly, 2001). Moreover, the view of social movements as unitary actors has already been corrected and greatly enriched by the idea of separating multiple social movement organizations (SMOs) within a movement (Zald and Ash, 1966; Zald and McCarthy, 1997). The Political Opportunity Structure approach to movements (McAdam, 1982; McAdam, McCarthy and Zald, 1996; Tarrow, 2011; Goodwin and Jasper, 1999) has also pointed to elite divisions as a crucial opportunity factor for movement 
success, introducing the feuding among political elites as a factor affecting state responses to challenges.

Recently, Fligstein and McAdam (2012) have added complexity to the study of social movements with their work on strategic action fields (see also Goldstone, 2004, and Goldstone and Useem, 2012, for additional approaches to social movements as elements in social action fields). Fligstein and McAdam separate the state into multiple policy fields, led by a multiplicity of "internal governance units," supported by a variety of "incumbents" and reshaped by the actions of numerous "challengers." Yet their terminology reveals their debt to the challenger/incumbent dualism of the older Polity model. It is not easily possible in Fligstein and McAdam's theoretical framework for actors to be simultaneously governance units, incumbents, and challengers within a single strategic action field. Yet that is exactly what we find throughout the essays in this book.

The fresh research in this volume produced by its distinguished contributors makes two novel points. First, there are no clear lines separating the roles of challenger (protestors or social movement activists), incumbents (those engaged in routine acceptance and membership in the polity defined by a policy field), and governance units (agents or institutions of the state). Second, the actors and structures within what we conventionally call governance units or state institutions or official positions are themselves a complex and constantly contested set, with some such actors sometimes indeed defending the policies of the governance unit, but at other times they or other state actors are found allying with certain specific incumbents against those policies, and at still other times they or other state actors are joining challengers to reshape the entire field.

Brian Doherty and Graeme Hayes skilfully point out the highly ambiguous yet critical role of courts within the state/social movement field. Courts are the arenas in which decisions are made whether to treat protestors as criminal or innocent, and hence whether their actions are justifiable. In meting out punishment, it is the courts who play a critical role in the repression (or concessions) to protestors, as the police act mainly to forestall or halt protest action and arrest protestors. Unless the police themselves choose to inflict punishment (and that does often happen, especially in repressive authoritarian regimes), it is the courts that decide whether and to what degree punishments are meted out to those acting outside of institutional channels to challenge prevailing policies.

Yet the court's role is ambiguous precisely because courts - especially in Anglo-American jurisprudence - are a composite. The state prosecutor is clearly the agent of the state, seeking to have the court enforce the state's 
view of justice and what should be done. The judge is no less an agent and representative of the state, but the judge's job is to act as impartial mediator in the arena. Then another state agent - the state appointed defense attorney, if the protestors do not obtain private counsel - is designated to act on behalf of the protestors and argue their case. And finally, yet another group, temporarily appointed by the state and granted the power to ascertain guilt or innocence, is explicitly chosen to represent what Tilly or McAdam and Fligstein would call the incumbents - members of society at large. That, of course, is the jury. We thus have career state agents on the side of the regime, on the side of the protestors (defendants), and mandated to be neutral, along with temporary state agents designed to represent neither the state nor the protestors but the broader society - all this within one unit of a unit of governance!

It should not be surprising that given this composite structure, courts have played a variety of roles, from conservative to radical, in history. From the earliest days of English courts, they were an arena (usually the sole arena) in which ordinary Englishmen could challenge the actions of lords (the King's courts being able to adjudicate such cases without control of the local landowner). In the years leading up to the French Revolution, Parisian courts undermined the authority of the Crown, as a series of sensational cases put the spotlight on the abuse of political power through private scandals, the most notorious being the "Diamond Necklace affair." The lawyers' briefs in these cases - published in print runs of tens of thousands in the 1770 s and 1780 s - were critical in shifting public perceptions of the Crown (Maza, 1993). In America, at various times, the courts were critical in enforcing the Jim Crow regime and in overturning it. At times, it has seemed that the greatest radical force in America has not been street protestors, but the US Supreme Court, as when it ruled racial segregation illegal, created a right of privacy that made first-trimester abortions legal, and now is moving steadily toward expanding the coverage of equal protection to people regardless of their chosen gender role. And the courts can be radical in other places and traditions as well: lawyers and courts played a major role in opposing the Pakistani ruler Pervez Musharraf, and were critical to overturning the manipulated election of Viktor Yanukovich in Ukraine in 2004, thus empowering the Orange Revolution.

Still, it is more often the case in authoritarian regimes that courts are much less ambiguous in their role. Rather than being composite and multi-sided, prosecutors, judges, and even defense attorneys collaborate to achieve convictions ordered by the regime, which treats the courts as simply putting a stamp of authority on the regime's desires and views. To 
raise a theme I shall return to several times in this essay, the field faced by social movements is very different in an authoritarian than in a democratic regime. In the former, the courts are usually - unless they defect and start to play a role in fomenting revolution - wholly agents of the state and act to support its interests. In democracies and some semi-democratic regimes, the courts have their own traditions and standards, and seek to act in ways that constrain state authority and often will support challenges to that authority.

Another ambiguous arena, as Katherine Krimmel demonstrates, is the legislature, due to the conflicts among political parties that occur there. The precise constellation of parties and legislative rules also shapes the field faced by social movements. And parties themselves, as I have shown elsewhere (Goldstone, 2003), have deep and multifold links to social movements: they may have begun as social movements that became institutionalized; they may be engaged in deep partnerships with social movements that provide votes and financial support for their candidates; they may either adopt or oppose the goals of specific social movements in order to gain votes or weaken their opponents; and the same actors may appear as social movement leaders, political party leaders and elected legislators and officials. The relation of parties to movements can shift dramatically over time: in the nineteenth century it was the Republicans who championed black rights and Democrats (especially Southern Democrats) who campaigned for Jim Crow; but by the late twentieth century these party roles and relationships had changed diametrically, so that it was the Democratic Party under President Lyndon Johnson that fought to make full civil rights for blacks the law of the land, while the Republican Party became the dominant party among Southern conservatives. Today it is the Tea Party movement - a movement of incumbents rather than challengers, dominated by the prosperous older white middle class - that has among the closest links to any political party, backing those Republicans who promise to lower their taxes and stop perceived threats from immigration and excessive state spending (Skocpol and Williamson, 2013; Van Dyke and Meyer, 2014).

Yet Krimmel points out that not only the party platforms matter, but the configurations of power in the legislatures as well. Where an open, multi-party structure prevails, as in many European parliaments, new parties based on social movements can easily gain entry to the legislature as parties, as with the Green parties or even the Pirate parties (favoring open information access) that have sprung up across the continent. In countries with a two-party structure, it is much harder for movements to enter politics without gaining allies in one of the major parties - although as a two-party system starts to breakdown, as in Britain, smaller parties 
can make themselves felt as well. Moreover, when a party system becomes so polarized and deadlocked that very little can be done, as in the United States at present, it becomes much harder for social movements to benefit from having allies in the major parties, and much harder for them to achieve any policy goals, as all sides seem bent on frustrating the aims of everyone seeking action.

Hélène Combes underlines for us the close relationship between parties and social movements by looking at Latin America, where this relationship has often been symbiotic. Moreover, Combes shows how very personal the relationship between movement and party can be, highlighting two individuals - Evo Morales in Bolivia and Luiz Inacio Lula da Silva in Brazil - who rose from being the leaders of social movements to the presidents of their country - quite a transition from challenger to head of the ultimate governance unit. Yet they essentially pursued the same policies throughout their careers.

Again, the context in which such a distinction does make sense is in one-party authoritarian regimes. In that context, the party and regime are often a single integrated organization, which seeks to squelch civil society and limit the influence of any independent social movements. Even in Latin America, Mexico under the years of domination by the PRI Party or Argentina under Perón are good examples of regimes that sought to incorporate all major organized social groups within the party and treated any social movement from outside the party as a hostile challenge.

The chapters by Imrat Verhoeven and Christian Bröer and by Donatella della Porta and Kıvanç Atak also show how actors that we think of as "state actors" can be incumbent or even challenging actors as well. Verhoeven and Bröer look at policy conflicts between municipal and national government in the Netherlands. This is a fairly common situation in multi-level and federal systems. In the United States, for example, federal policy on marijuana and gay marriage is being openly challenged by state and local governments who have legalized both. In these cases is it non-federal but clearly state actors (lower-level governance units) who are challenging the policies of peer and higher-level governance units.

This is not a matter of revolution or radical or unusual circumstances. Rather, it happens quite frequently that various governance units in the same system differ on policies and challenge each other either through contrary legislation or through the courts. When we have various governance units in conflict, and that conflict is mediated by the courts, but the courts are trying to mediate between the letter of the law and popular sentiment as expressed through media and the actions of social movements, we have a 
complex field of action indeed! When gay rights activists succeed in placing a referendum to approve gay marriage on the ballot, which is defeated (as in California), it appears that "challengers" have been turned back by "incumbents." But what if the courts then reverse that outcome by saying that gays have a legal right to marry that is based on the state constitution, and state legislators act to affirm that right? Have the "governance units" then become the "challengers" who are acting against the "incumbents"?

A similar tale can be told of policing, again with the caveat that the role and options of police create very different fields in authoritarian and democratic regimes. della Porta and Atak show very clearly that the institutional constraints and behavior of police are very different in authoritarian and democratic societies (I have argued this as well; Goldstone, 2012). In authoritarian societies, the police treat social protestors as enemies of the state to be stopped at all costs. They will use lethal force, follow up arrests with imprisonment and often torture to break the will of protestors, and impose long jail terms on the leaders of protests. In democratic societies, by contrast, police treat protestors (if peaceful) as exercising legal rights. They may try contain the protests to permitted spaces, but if things get out of hand they will use non-lethal force (mainly tear gas, in extreme cases water cannon and rubber bullets). More important, most of those arrested will be released, and the leaders are likely to be called to bargain over group demands rather than shut away for long terms in prison. Police thus play very different roles vs. social movements, as enabling vs. disabling, in democracies vs. dictatorships. Indeed, as Joseph Luders (2010) has shown by contrasting the conduct of various local authorities during the Civil Rights Movement, when the police exceeded the bounds of expected reasonable response to protests, their actions delegitimized the state government and policies they were trying to protect, and helped catalyze national support for the Civil Rights Movement. In areas where police were far more restrained, their actions generated no national outcry and produced more moderate outcomes.

If police can be variable in how they shape the arena of protest and how their interactions with protestors shape outcomes, this is even more true for armies and militia. Ian Roxborough shows very clearly that when viewing the assemblage of army, police, constabulary and militias engaged in responding to social protests, we must "abandon ... any notion that we are dealing with a unified actor, much less a unified and coherent rational actor" (p. 133). Roxborough nicely demonstrates, through an outstanding analysis of the evolution of Ireland's independence movement in the late nineteenth and early twentieth centuries, that the British government was 
unable to mount a coherent response in part because of its incomplete control of various elements of its army, the Irish constabulary, the Ulster militias, and the police, each of which had different approaches and levels of commitment to fighting the actors involved in the movement for Irish independence. Eventually, this incoherence and conflicting agendas enabled the Irish to prevail and win their own state - with, once again, the leaders of a social movement becoming the leaders of the new government.

Even in authoritarian states, the repressive forces of the state may be divided. In the Tunisian and Egyptian revolutions, the excessively harsh and humiliating treatment of petty opposition (including the horrific death of Khaled Said) by the police eventually led to massive protests. Yet the police by themselves, however good at informing on the opposition and controlling limited demonstrations, were simply unable to cope with uprisings that grew to include tens of thousands. However, the army, when called upon, refused to attack the revolutionary crowds, and indeed moved to protect them and support their demands for a change in regime. As analysts of state forces from Katherine Chorley (1943), Stanislaw Andrzejewski (1954), and D.E.H. Russell (1974) to Zoltan Barany (2011) have shown time and time again, the loyalty of the army is critical to authoritarian regimes when facing large-scale protests. Yet the armed forces themselves are often internally divided, with those divisions reflecting the cleavages in the broader society (Goldstone, 1991: 241-243). Ethnic divisions, or strife between junior and senior officers, or even inter- and intra-service divisions (as in the USSR in 1991, when elements of the military leadership planned and began a coup only to find that other elements in the military leadership would not support them), and not simply the defection of the army as such, may be the factor that transforms the social movement field.

David Cunningham and Roberto Soto-Carrión provide a fascinating narrative of how the ambiguity in the role of police extends right down to the role of certain individuals. Infiltrators are required to simultaneously act as police and as social movement activists. The brilliance of this chapter is to show that infiltrators for the FBI - George Dorsett and Gary Thomas Rowe in the KKK, and Ernest Withers in the Civil Rights Movement - were not just tools of the police. Rather, they played their role on both sides with skill and autonomy. Withers in particular made such singular contributions to the progress of the Civil Rights Movement that he was acclaimed as an activist, so much so that the revelation of his role as an FBI source was greeted with incredulity. Again, we find the overlap of challengers, incumbents, and governance units not merely across organizations or time, 
but simultaneously, for long periods, within the role and actions of single individuals.

The last two chapters in this volume, by Vince Boudreau and Clifford Bob, demonstrate the importance of arenas in shaping the interaction of states and protestors. Showing very clearly that not all governance units are alike, these two essays span a range - from the dictatorships examined by Boudreau to the multinational global governance unit that the UN aspires to be, examined by Bob.

In Boudreau's dictatorships, regimes have to calculate how to deal with dissent in a way to preserve their power at the least cost to their legitimacy. Still, that usually leaves challengers isolated and incumbents intimidated, except in the exceptional conditions of state breakdown that can lead dictatorships to dissolve suddenly in revolutionary tumults (Goldstone, 2014). By contrast, in the sprawling, multi-level multinational arena that is the $\mathrm{UN}$, the name of the game is forming broad coalitions with those desiring to keep gay rights off the UN Human Rights agenda (the "Baptist-burqa alliance") in order to prevent gay rights from becoming a core part of UN concerns. On both sides, extensive networks of NGOs jockey for position, allies, and influence. Yet this is not merely a matter of challengers acting against government forces; indeed, there really are no forces in the UN governance unit acting for or against either side. Rather, what we see is different NGO networks trying to leverage organizational elements of the UN's procedures to gain institutional support or to block and frustrate action. The governance unit in this case shapes the field not by its actions, but by its structure, which provides certain avenues and limits on how NGOs can seek to create changes in global standards for treatment of gays and lesbians in diverse societies. Nor would the UN even be relevant, except for the fact that many other governance units - those of the member states - are themselves in conflict over the issue. Perhaps the best way to describe this field is one in which international networks of incumbents (with significant power in their own societies) are jockeying for control of decisions in one governance unit (the UN) in the hope of influencing the policies of other governance units (the member states). This is the "global movement boomerang" discussed by Margaret Keck and Katherine Sikkink (1998; see also della Porta and Tarrow, 2005; Smith, 2010).

To sum up, the essays in this volume force us not only to shift away from the simply dyadic core of the state/social movement relationship, but also to move beyond existing schemes of social movement fields, which are still too simple to guide us in understanding the options and constraints that both movements and state actors face. The fields of social movement 
action in this book show enormous overlap among movement actors, incumbents (or bystanders) and governance units, both as individual actors and organizations. At the same time, they show enormous internal divisions and conflicts and role shifting within social movements, among incumbent groups, and inside of states. In Figure $\mathrm{C}_{2}$, I have tried to redraw the space of social fields in a way consistent with this reality.

Figure C2 A More Complex View of Fields of Action for Social Movements

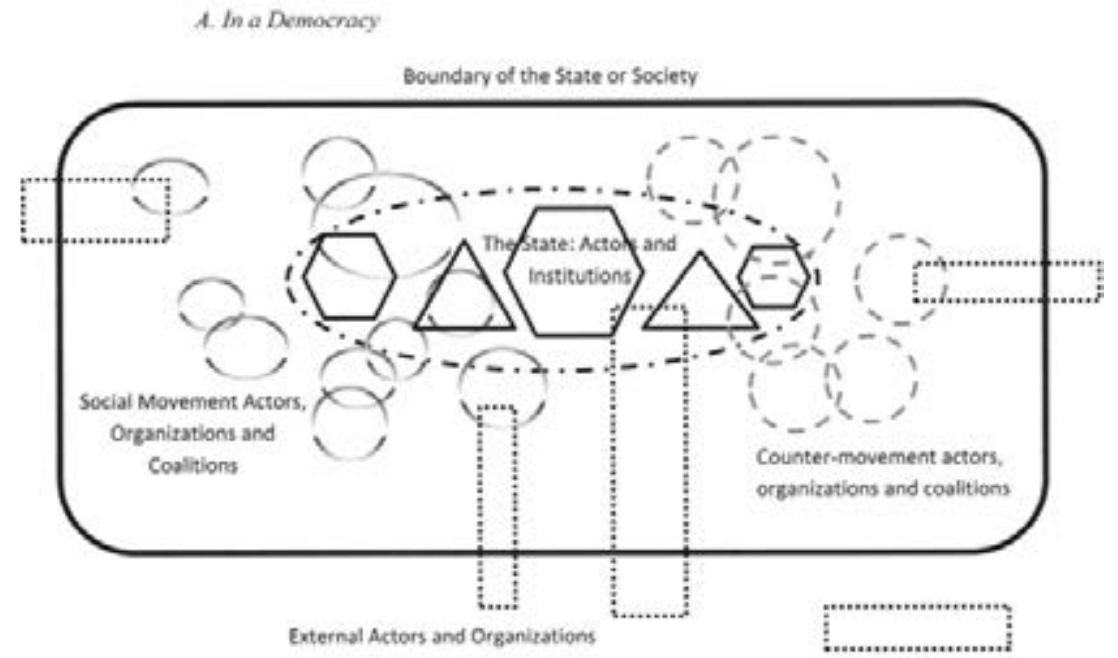

B. In an Awhoritarian Regime

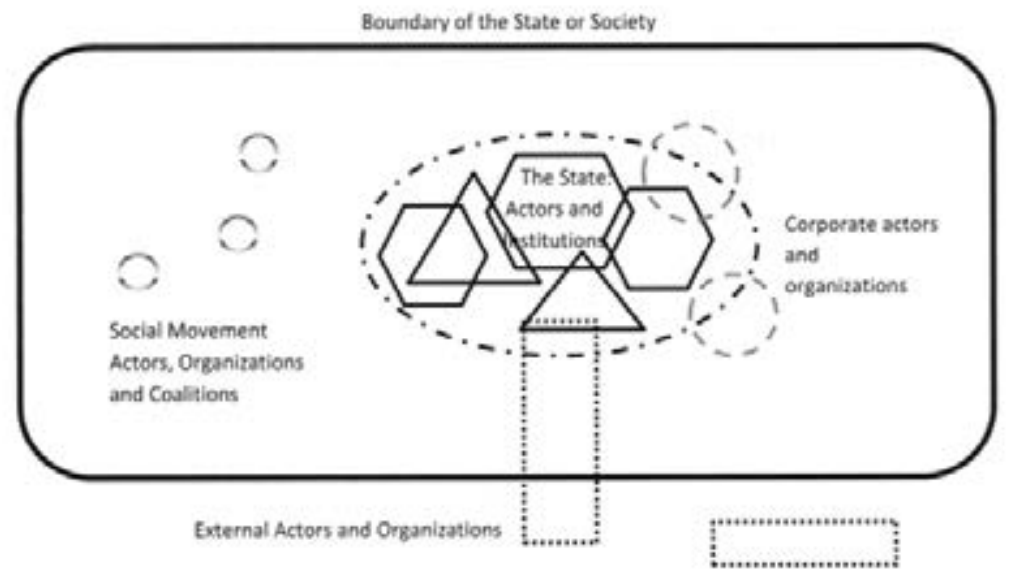


The upper portion of Figure $\mathrm{C}_{2}$ (Part A) shows the social movement field typically faced by a social movement in a democratic society. Within the boundary of the society, there are no clear lines separating challengers, incumbents (everyone is in the boundary of the state), and the state. There are multiple challengers and challenging organizations, with diverse links among them. Some of these - such as the municipal governments in the Netherlands discussed by Verhoeven and Bröer or the state governments in the United States that have legalized the sale of marijuana - are wholly inside the state or are themselves governance units. The actors and institutions within the state are varied and disparate with considerable autonomy and separation among them, having varied links to challengers and external actors and organizations (which also link to various challengers and other groups). As one example, the anti-gun control movement in the United States is led by the National Rifle Association (NRA). Many members of Congress are proud members of the NRA, which engages in action both through protest and through institutional political action (supporting party candidates, helping to draft legislation, and bringing actions in courts to defend gun ownership). At the same time, there are over a thousand antigun control groups that the Southern Poverty Law Center (2013) defines as "patriot groups" and "anti-government militias" driven by their fear that authorities will strip them of their guns and liberties and that act far more radically and wholly outside the state. The field also includes countermovements, which also have varied links among themselves, to state actors and institutions, and external actors and organizations (Meyer and Staggenborg, 1996).

A similar but still distinct field configuration of these elements is shown as typical for authoritarian regimes in Part B. In these fields there are relatively few challenging groups and they are wholly outside the state. The state itself is more tightly integrated and unified. There are other organized groups in society, but they are not challengers; rather, they tend to be corporatist groups allied with the state. Meanwhile, the state dominates relations to external actors and tries to exclude social groups inside society from linking up with external and international organizations except with its approval.

Comparing Part A and Part B, it is possible to see how transitions take place from authoritarian to democratic fields. In an authoritarian society, the number of challenging groups and the links among them increase; within the state the separation and differences among state actors and units increase as well, and some of them start to link to challenging groups (Tilly 2003). Meanwhile, external actors may become more active in supporting 
challengers or reducing support of the state. In short, as the field structure in Part B changes to more closely resemble that in Part A, pressures for a shift to democracy grow, though whether that results in gradual reform (as with the PRI regime in Mexico or the end of Franco's regime in Spain) or more rapid decay (as with the collapse of the USSR) or even revolution (as with the color revolutions in the Philippines, Eastern Europe, and elsewhere) depends on local conditions and the degree of resistance to change.

Is this now too complex a reality to deal with? I would argue not. Indeed, what I believe this volume makes clear is the limits on analysis we face in treating the state, or social movements, or the rest of society, as composed of distinct sets of self-interested actors pursuing characteristic goals across various settings or arenas. Modern complexity theory, as applied to social systems, tells us very clearly that we often cannot explain social outcomes by adding up the separate goals and actions of particular actors or groups taken individually (Root, 2013). Rather, social outcomes emerge from the multiple interactions of various actors and groups in highly non-linear fashion. Relationships move toward tipping points, coalitions build and expand, and security forces hold then suddenly divide and break. Thus, we need to focus more on seeing how state, movement, and social groups and actors overlap and forge relationships, how those relationships shift, and how the arenas and institutions in which they are working shape and constrain their choices and actions. Only then can we do justice to the true dilemmas of social movement actions, and the complex dynamics of how social movements shape society.

\section{References}

Allison, Graham, and Philip Zelikow. 1999. Essence of Decision: Explaining the Cuban Missile Crisis, $2^{\text {nd }}$ ed. New York: Longman.

Andrzejewski, Stanislaw. 1954. Military Organization and Society. London: Routledge \& Kegan Paul.

Barany, Zoltan. 2011. “Comparing the Arab Revolts: The Role of the Military.” Journal of Democracy 22: 24-35.

Chorley, Katherine. 1943. Armies and the Art of Revolution. London: Faber \& Faber.

della Porta, Donatella, and Sidney Tarrow, 2005. Transnational Protest and Global Activism. Lanham, MD: Rowman and Littlefield.

Fligstein, Neil, and Doug McAdam. 2012. A Theory of Fields. New York: Oxford University Press. Gamson, William A. 1975. The Strategy of Social Protest. Homewood, IL: Dorsey Press.

Goldstone, Jack. A. 1991. Revolution and Rebellion in the Early Modern World. Berkeley and Los Angeles: University of California Press. 
—. 2004. "More Social Movements or Fewer: Beyond Political Opportunity Structures to Relational Fields." Theory and Society 33: 333-365.

-. 2012. "Protest and Repression in Democracies and Autocracies: Europe, Iran, Thailand, and the Middle East, 2010-2011." In Seraphim Seferiades and Hank Johnston, eds., Violent Protest, Contentious Politics, and the Liberal State. Farnham, Surrey, UK: Ashgate.

-. 2014. Revolutions: A Very Short Introduction. New York: Oxford University Press.

—, ed. 2003. States, Parties, and Social Movements. New York: Cambridge University Press.

Goldstone, Jack A., and Bert Useem. 2012. "Putting Values and Institutions Back into the Theory of Strategic Action Fields." Sociological Theory 30: 37-47.

Goldstone, Jack A., and Charles Tilly. 2001. "Threat (and Opportunity): Popular Action and State Response in the Dynamics of Contentious Action." In Ron Aminzade, Jack A. Goldstone, Doug McAdam, Elizabeth L. Perry, William H. Sewell Jr., Sidney Tarrow, and Charles Tilly, eds., Silence and Voice in the Study of Contentious Politics. Cambridge: Cambridge University Press.

Goodwin, Jeff, and James M. Jasper. 1999. "Caught in a Winding, Snarling Vine: The Structural Bias of Political Process Theory." Sociological Forum 14: 27-54.

Keck, Margaret E., and Kathryn Sikkink. 1998. Activists beyond Borders: Advocacy Networks in International Politics. Ithaca: Cornell University Press.

Luders, Joseph. 2010. The Civil Rights Movement and the Logic of Social Change. Cambridge: Cambridge University Press.

Maza, Sara. 1993. Private Lives and Public Affairs: The Causes Célèbres of Prerevolutionary France. Berkeley and Los Angeles: University of California Press.

McAdam, Doug. 1982. Political Process and the Development of Black Insurgency, 1930-1970. Chicago: University of Chicago Press.

McAdam, Doug, John D. McCarthy, and Mayer Zald. 1996. Comparative Perspectives on Social Movements: Political Opportunities, Mobilizing Structures and Cultural Framings. Cambridge: Cambridge University Press.

Meyer, David S., and Suzanne Staggenborg. 1996. "Movements, Countermovements, and the Structure of Political Opportunity," American Journal of Sociology 101: 1628-166o

Root, Hilton. 2013. Dynamics among Nations. Cambridge, MA: MIT Press.

Russell, Diana E. H. 1974. Rebellion, Revolution, and Armed Force. London: Academic Press.

Skocpol, Theda, and Vanessa Williamson. 2013. The Tea Party and the Remaking of Republican Conservatism. New York: Oxford University Press.

Smith, Jackie. 2010. Social Movements for Global Democracy. Baltimore: Johns Hopkins University Press.

Southern Poverty Law Center. 2013. The Year in Hate and Extremism. Intelligence Report No. 149 (Spring). Available at: http://www.splcenter.org/home/2013/spring/ the-year-in-hate-and-extremism.

Tarrow, Sidney. 2011. Power in Movement: Social Movements and Contentious Politics, $3^{\text {rd }}$ ed. Cambridge: Cambridge University Press.

Tilly, Charles. 1978. From Mobilization to Revolution. Wellesley, MA: Addison-Wesley.

—. 2000. "Processes and Mechanisms of Democratization." Sociological Theory 18.1: 1-16.

Van Dyke, Nella, and David Meyer, eds. 2014. Understanding the Tea Party Movement. Farnham, Surrey, UK: Ashgate.

Zald, Mayer N., and John D. McCarthy. 1997. Social Movements in an Organizational Society: Collected Essays. New Brunswick, NJ: Transaction Publishers.

Zald, Mayer N., and Roberta Ash. 1966. "Social Movement Organizations: Growth, Decay and Change." Social Forces 44: 327-341. 



\section{Contributors}

Kıvanç Atak is currently a research associate at the Centre on Social Movement Studies, European University Institute in Florence. Atak conducts research mainly in the field of political sociology. More specifically, he works on protest mobilization and policing, public order policy and state repression.

Clifford Bob is the author of The Marketing of Rebellion and The Global Right Wing and the Clash of World Politics. He has written for political science, law, and policy journals, and his opinion articles have appeared in newspapers such as the International Herald Tribune, Los Angeles Times, South China Morning Post, Sydney Morning Herald, San Francisco Examiner, and Pittsburgh Post-Gazette. With James Jasper he edits the Oxford Studies in Culture and Politics. He is professor of political science and Raymond J. Kelley Endowed Chair in International Relations at Duquesne University.

Vince Boudreau is dean of the Colin Powell School for Civic and Global Leadership at the City College of New York, and a member of the CCNY Department of Political Science. He writes about state repression and regime transitions with a particular emphasis on the Southeast Asian context. His written works include Resisting Dictatorship: Repression and Protest in Southeast Asia.

Christian Bröer is a sociologist at the University of Amsterdam whose work centers on the relation between private troubles and public issues. Empirically he focuses on issues of (mental) health, noise, and risk. He is associate professor and leader of the program group Political Sociology.

Hélène Combes is a CNRS scholar affiliated with the Centre d'études et de recherches internationales (CERI Sciences Po Paris). She works on parties and social movements in Mexico. With Sergio Tamayo, she recently oversaw a collective study of protests in Mexico City and is the author of a book on the relationship between parties and social movements (Faire parti). She has published many articles on mobilizations in Mexico and co-edited journal issues devoted to methods for studying parties $(R I P C)$ and social movements (Politix).

David Cunningham is professor and chair of the Department of Sociology at Brandeis University, and he also directs the university's interdisciplinary 
program in Social Justice and Social Policy. His current research focuses on the causes, consequences, and legacy of racial violence, and he has been supported by the National Science Foundation, the Spencer Foundation, and the Harry Frank Guggenheim Foundation. His latest book is Klansville, U.S.A: The Rise and Fall of the Civil Rights-Era Ku Klux Klan.

Donatella della Porta is professor of sociology in the Department of Political and Social Sciences at the European University Institute, where she directs the Center on Social Movement Studies (Cosmos). She also directs a major ERC project, Mobilizing for Democracy, on civil society participation in democratization processes in Europe, the Middle East, Asia, and Latin America. Her recent publications include Mobilizing for Democracy; Can Democracy be Saved?; Clandestine Political Violence; The Wiley-Blackwell Encyclopedia on Social and Political Movements (edited with D. Snow, B. Klandermans, and D. McAdam); Mobilizing on the Extreme Right (with M. Caiani and C. Wagemann); and Meeting Democracy (edited with D. Rucht).

Brian Doherty is professor of political sociology at Keele University. His publications include Environmentalism, Resistance and Solidarity: The Politics of Friends of the Earth International; Ideas and Actions in the Green Movement; Beyond Borders: Environmental Movements and Transnational Politics; Direct Action in British Environmentalism; and Democracy and Green Political Thought. He is a consulting editor of Social Movement Studies and a member of the editorial board of Environmental Politics.

Jan Willem Duyvendak teaches at the University of Amsterdam. His recent co-edited volumes include Immigration and the New Urban Landscape and European States and Their Muslim Citizens. He is co-editor, with James Jasper, of Players and Arenas, and of AUP's Protest and Social Movements series.

Jack A. Goldstone is Virginia E. and John T. Hazel Professor of Public Policy at George Mason University and a visiting scholar at the Woodrow Wilson Center. His works include Revolutions: A Very Short Introduction; States, Parties, and Social Movements; Political Demography; and Revolution and Rebellion in the Early Modern World. He has won the American Sociological Association's Distinguished Contribution to Scholarship Award, the Historical Society's Arnoldo Momigliano Award, and the International Studies Association's Myron Weiner Award. 
Graeme Hayes is reader in French and social movement studies in the School of Languages and Social Sciences, Aston University, UK, and visiting professor at the Institut d'Etudes Politiques de Rennes, France. He is the editor of Social Movement Studies, author of Environmental Protest and the State in France and La Désobéissance Civile (with Sylvie Ollitrault), and co-editor of Occupy! A Global Movement; Olympic Games, Mega-Events, and Civil Societies; and Cinéma et Engagement.

James M. Jasper has written about politics and protest for more than 30 years. His most recent book is Protest: A Cultural Introduction to Social Movements. He teaches at the Graduate Center of the City University of New York.

Katherine Krimmel received her PhD from Columbia University in 2013 and is currently an assistant professor in the Department of Political Science at Boston University. She was a 2012-2013 National Fellow at the Miller Center for Public Affairs at the University of Virginia. Her dissertation examines changes in group-party relations in the United States since the New Deal.

Ian Roxborough is professor of history and sociology at Stony Brook University. He earned a PhD in sociology at the University of Wisconsin at Madison and has received fellowships to conduct research on military strategy, counterinsurgency, and military cognitive frames from the Institute for Advanced Study, in Princeton, NJ, and the Carnegie Corporation of New York. Most recently he has worked as a member of a research team on military occupations and interventions, funded by the Office of Naval Research.

Robert Soto-Carrión is a graduate student at Brandeis. His research explores the role of race in the formation and proliferation of tourism in Salvador da Bahia, showing how racialized cultural activities are marketed by the tourism industry as "authentic" to promote tourism to Salvador and the ways in which conceptions of blackness and citizenship are challenged and (re)negotiated. He is also a full-time volunteer and coordinator for the International Youth Leadership Institute (IYLI).

Imrat Verhoeven is an assistant professor in public policy in the Department of Political Science of the University of Amsterdam. His current research interests are contentious governance and governmental activism, policy conflicts, emotions and public policy, citizens' initiatives, and activation policies of changing welfare states. 



\section{Index}

advocacy coalition theory 218-219

agrarian conflict 135

American Psychological Association (APA) 215-216

Amnesty International 208

anti-gay rights players 21, 205-206, 208-209, 218-220, 233

Arcus Foundation 208, 217

arenas see strategic arenas

armies 14, 231

autonomy $11,13,18,55-57,97-98,119-120,170$,

$174-175,207,232,235$

auxiliary police $133,142-143,155$

baptist-burqa coalition 215, 218-221, 233

Black and Tans 21, 133, 142-143, 146, 150, 155

Bloody Code 29

Bob, Clifford 19, 21, 205, 233, 239

Bolshevism 151, 154

Brazil resolution (2003) 210-211, 216

British Army 133, 138, 142-148, 152-153, 155

bystanders 9, 20-21, 96, 98-99, 108, 118, 179,

182-185, 188, 190, 192-193, 195-199, 234

Caen, anti-nuclear trial 45-46

cartel, party $55,84-85$

case studies 108, 162

Catholic Family \& Human Rights Institute

(C-FAM) 209, 213-215

Catholics 133-136, 138-139, 149, 153, 213, 215, 217

Catholics for a Free Choice (CFFC) 213-214, 217

Catonsville Nine 33

Chicago Eight 41

Chicago School 9

China 15

civic crime 30-31

civil rights movement $16,82-83,86,88,162-166$,

171-175, 229, 231-232

Civil War, Ireland 133-149

claims making $18,28,97,102$

class conflict $29,15^{2-153}$

Climate Change activist trials 36-37, 39, 46-47

coalition-building $80,90,214-215$

cognitive frames $21,107,133$

cognitive schemas 125-126, 129-130, 134

COINTELPRO 117, 165

collective identities 10, 12-13, 21, 30, 48

Collins, Michael 145

community policing 117,123

complexity 11, 20, 183, 227, 236

compound players see strategic players

Confederate Knights of the Ku Klux Klan 166,
Congressional Committees 82-90

consensus procedures 206, 218

consultative status 206, 212-214

contention 18, 97, 102-103, 106-107, 123, 134, 157,

159, 167, 175-177, 179(n), 18o, 182-186, 191(n),

221

Contentious governance 95-108

Cork, Ireland 142, 147-148

Council of Europe 106, 215

counterglobalization movements 129

co-optation $56-57,64$

countermovements $17,32,43,76,186,218,235$

countermovements theory 218

counterstate 140

courts 12, 17-18, 27-49, 99, 120, 141-142, 185, 225 , 227-231, 235

culture 9, 17, 32, 38, 90, 115, 125-126, 133, 135, 205,207

\section{Dail Eireann 140-141}

Dalai Lama 217

Déboulonneurs movement 42, 44

DeChristopher, Tim 39-40, 46

dictators 14, 20-21, 53-54, 179-188, 191-194, 197, 199, 231, 233

direct action crime 30-31, 34-35, 37, 42-43, 46-48

discharge petitions $85^{-86}$

Doha Declaration (2004) 212, 220

Dorsett, George 165-172, 174-176, 232

Dublin Metropolitan Police 133, 135, 142

Easter uprising (Ireland) 138-140, 149-150

Eastview 13 klavern 166, 170, 173, 175

Economic and Social Council (ECOSOC) 207, $210,212-213$

elite allies $75^{-7}$ 6, 80, 91-92

escalated force 121-122, 124, 130

European Union 208, 215

Evers, Medgar 164

exclusivity decisions 182, 186, 190, 199

Faucheurs Volontaires 44-45

Federal Bureau of Investigation (FBI) 128, $157-158,161-176,232$

fields $17,227-236$

filibuster 88-89, 92

Focus on the Family 209

Ford Foundation 208

Foucault, Michel 14-16

Framing 32, 97-98, 141, 150, 153, 221

Frierson, Dargan 169-170, 174

Frongoch 139

Front de Libération Nationale (FLN) 40 
Gaelic revival 135, 138

game theory $9,18-19$

gay rights players 21, 90-91, 205, 207-212, 215,

217-221, 231

gendarmerie 128-129, 135

Genetically Modified Organisms, activist trials $45-46$

Germany 45, 96

Goldstone, Jack 16-17, 21, 54, 133, 225, 240

good and bad protestors 126

Goodwin, Jeff 14

governance $20,79,95-108,127,227-228,230-235$

governmental players 95-108

Greenham Common Women's Peace Camp 41

Greenpeace 36-37, 43, 45

guerrilla warfare 139-140, 144-148

handlers 158, 161-162, 166-176

Holy See (Vatican) 209, 213-214, 216

Home Rule 133, 136-137, 149, 151, 153

Hoover, J. Edgar 165-166, 173

House of Representatives 82-84, 87, 91, 165

Howard Center for Family, Religion and Society 209

Human Life International (HLI) 213

Human Rights Campaign Fund 75, 213

Human Rights Council 207

Human Rights Watch (HRW) 208, 213, 215-216

hunger strike 141-142, 149

industrial conflict 142, 151, 154

infiltrator 21, 157-177, 232

informant 146, 157-176

information 35(n), 76, 80, 99, 101-102, 105, 108, 117-118, 120, 123-126, 163-164, 167-168, 170-175, 190, 196, 219, 229

INRA (National Agricultural Research Institute, France) 46

institutional activism 98-99

insurgency $63,133-155$

intelligence $117,123,128,130,133,139,146,15^{2}$, $157(\mathrm{n}), 160,164,173$

intensity decisions 182,186

International Commission of Jurists (ICJ) 210-211

International Gay and Lesbian Association (ILGA) 207-208, 212-213, 215, 220

International Gay and Lesbian Human Rights

Commission (IGLHRC) 207-208, 213, 215

International Service for Human Rights 210

Irish Free State 149

Irish Parliamentary Party 140

Irish Republican Army (IRA) 138, 141-142, 144-149, 152-153

Irish Republican Brotherhood (IRB) 138-139, 141

Irish Volunteers 136, 138-139

issue coalitions 98-99
Jones, Bob 166

judges (see also magistrates) 10, 29, 34, 35(n), $37-39,43,45-46,48,212,228$

juries 20, 29, 31, 33-40, 42, 45, 48, 141, 228

Kemp, Barrett 170, 173-174, 176

Ku Klux Klan (KKK) 164-166, 168-171, 174, 176, 232

labor $82-83,86,108,119,126,138,153$

lawful excuse, as trial defense $36-39,47$

Lawrence, William H. 164, 171-172

laws 11-12, 20, 27-41, 47-48, 76, 90, 102-103, 118$119,180,188,205,210,214,216,218,229-230$

lawyers $28-29,38,40,43-44,48,212,228$

legal mobilization 28

legitimacy 30-31, 40, 44, 62-63, 97, 117-118, 126, 140, 151, 161, 191, 221, 233

LGBT movement 75-76, 91

Li, Lianjiang 15

Liberal Party 137

Little Rock, AR 163

Lloyd George, David 143-144, 148, 150, 155

Macready, Sir Neville 143-144, 146, 154

MacSwiney, Terence 142

magistrates (see also judges) 31, 33-36, 42, 44, 46

martial law 142, 148

martyrs 138-139, 141-142, 153

Marx, Gary T. 157(n), 158-159, 167-168, 171

Marxism 9, 13-14, 16, 29, 116, 214

Marxist approaches to policing 123

mast siting 96, 99, 103-107

McWhorter, Loyal 166

media $9,12,17,20,29,32,39,43,47-48,63,66$, $69,90,106,111,127,160,181,184,205,230$

Memphis, TN 162-164, 171-172, 174

military 13, 127-129, 133-155, 191, 197, 232

military conscription 139-140

militias 129, 134, 136, 138, 151, 186, 231-232, 235

mobile phone antennas 96

mobilization 19, 28, 53-54, 57, 6o, 64, 65(n), 67, $71,76,80,95-98,101-103,107,121,123,125,151$, $159,163,180,185,219$

municipal amalgamation 96, 99-102, 107-108

nationalism $134-136$

nations $13,18,64,80,83,91,119,129$

naughty or nice dilemma 20-21, 137

negotiated management 121-122, 124, 130

non-governmental organizations (NGOs) 58 , 205-210, 213-214, 218, 233

non-policies 217, 221

Norms 11, 20, 30, 43, 77, 80, 85, 92, 114, 145, 158, $185,191,193,196-199$, 208-209, 211-212, 214 , 218,220

North American Man Boy Love Association (NAMBLA) 212-213, 220 
O'Brien, Kevin 15

obstruction 82, 88-89

Organisation of the Islamic Conference (OIC) 210,216

Paget, Sir Henry 137

party leaders $61,68,84-85,87-89,92,229$

Pearse, Patrick 138-139, 153

persuasion 17-18, 28, 80, 176

Platform for Action of the Beijing Women's conference (1995) 210

players see strategic players

Plowshares movement 42

Polarization 89-90, 92

police

police culture $125^{-126}$

police knowledge 126,130

police strategies 113-130

policy conflicts 95-96, 99, 107, 230

policy implementation $11,15,19,95,100,120$

political economy $83,115,127$

political opportunities $15-17,56,98,218,220$, 226

political opportunity theory 17,226

political parties $17,20,53-72,75^{-92}, 99,229$

powerful allies dilemma 12, 20

problem construction 219

professionalization $34,78,80,128$

protest 9, 14-16, 20-21, 27, 30-31, 39, 41, 43-44, 46, 58-61, 63-64, 68-71, 78, 85-86, 96, 98, 101-108, 114-130, 133, 135-136, 140-142, 149, 155, $163,177,179-180,185,193,211-212,227-228$, 231-232, 235

protest policing 21, 114, 118-122, 124, 126-127, 129-130

Protestants 133-137, 149, 151, 153, 215

provocateur 157-159, 162

public opinion 10, 12, 90, 105, 126, 139, 150, 152-153

public order 35, 113, 118-120, 122, 128, 189, 197

publicity decisions 182, 186, 190

Rational Choice Theory 9

Redmond, John 137

repertoire 16, 30, 108, 122, 134, 149-150, 179

repression $27,32,69,117,129,155,159-160,162$,

179-199, 226-227

reprisals $143,145-146,149,154,170$

revolutions 14, 61, 83, 139, 142, 148, 154, 228-229, 236

rules 10-12, 20, 29, 33, 42-44, 48-49, 77, 80, 85,

91-92, 107-108, 117, 130, 188-189, 191, 196, 207, $214,220,229$

right to protest $117-118,121$

riot squads 119,123

rival norms 211-212

Rowe, Gary Thomas 166-167, 170-176, 232

Royal Irish Constabulary 133, 135, 141, 232

Royal Ulster Constabulary 149
Rules Committee 86-87, 91

rupture, strategy of in trials 40-41

sanitation workers' strike in 163

sectarian conflict 133-134, 136, 149, 151, 153

security $36,66,115-116,127,162,179,181,184,190$, 193-199, 236

Senate $63,82,85,88-89$

seniority $82-83,86$

sexual orientation and gender identity 208-211, $215^{-219}, 221$

Sinn Féin 139-143, 148-149, 151, 153

Skocpol, Theda 10, 13-14

social control 115-116, 159, 190

social crime 29-31, 44-47

Social movements 9-13, 16-17, 20-22, 27-32, 48, $54-58,62,64,67,69-71,75-78,80-82,84-88$, 90-92, 95-99, 104-108, 114-115, 122, 130, 145, $157-158,161-162,175^{-177}, 219-220,225^{-23} 6$

soft law 209-212

Solemn League and Covenant 136

Speaker of the House 82, 87, 92

special rights $216-217,221$

States 9-22, 27, 29-31, 33, 39-40, 43-44, 47-49, 54, 56-57, 6o(n), 61, 64, 81, 95, 97-99, 107, 114-116, 121-122, 129-130, 133, 157-162, 167, 179, 181-199, 205-208, 211, 218, 225-236

strategy

strategic action $11,160,227$

strategic arenas $27-49$

strategic capacity 176

strategic incapacitation 124-125, 130

strategic interaction 9, 14, 22, 40, 47-48, 96, 101, $103,106,134,158,182,218$

Strategic players 14,158

structural holes 168

structural veto 82

structuralism 9

sub-arenas 206-207, 209-212, 217, 220

summits 122-123, 127

surveillance 116, 119, 123-124, 127, 130, 159

tactics

tactical adaptation 29

tactical innovation 148

tactical interaction 43

tactical repertoires $149-15^{0}$

targeting decisions $182,186-187$

taxes 11, 229

technology 103-106, 123

Tilly, Charles 10, 16, 18, 30, 95, 140, 162(n), $183^{-184}, 189,191(\mathrm{n}), 221,225-226,228$

Touraine, Alain 181

transnational policing 123, 125, 127, 129-130

Tudor, Henry 143

Tutu, Desmond 216-217

Ulster 133-134, 136-137, 149, 151, 153

Ulster Volunteer Force 136 
UN Conference on Women in Mexico City (1975) 210

United Families International (UFI) 209, 216 United Klans of America (UKA) 165-166, 169-170, 174

United Nations 9, 205-221, 233

Vatican see Holy See

Vergès, Jacques 40-41

vertical dimension 158, 161-162, 167

Veto players 82

Viola Liuzzo murdered by 166-167, 171 war on terror 117,123

Watson, Lance "Sweet Willie Wine" 164

Weber, Max 13

White Hate Groups program 164-165

Wilson, Sir Henry 143-144, 146, 154

Withers, Ernest 162-164, 167, 171-172, 174-176, 232

witnesses (as players in trials) 43, 45-46, 48

Wolseley, Lord Garnet $15^{2}$

Yogyakarta Principles 210-211, 220

zombie policies 19, 221 